\title{
Increased CPC Batch Size Study for Tank 42 Sludge in the Defense Waste Processing Facility
}

by

W. E. Daniel

Westinghouse Savannah River Company

Savannah River Site

Aiken, South Carolina 29808
RECENV

JAN 182008

OSTI

DOE Contract No. DE-AC09-96SR18500

This paper was prepared in connection with work done under the above contract number with the U.S.

Department of Energy. By acceptance of this paper, the publisher and/or recipient acknowledges the U.S.

Government's right to retain a nonexclusive, royalty-free license in and to any copyright covering this paper, along with the right to reproduce and to authorize others to reproduce all or part of the copyrighted paper. 


\section{DISCLAIMER}

This report was prepared as an account of work sponsored by an agency of the United States Government. Neither the United States Government nor any agency thereof, nor any of their employees, makes any warranty, express or implied, or assumes any legal liability or responsibility for the accuracy, completeness, or usefulness of any information, apparatus, product or process disclosed, or represents that its use would not infringe privately owned rights. Reference herein to any specific commercial product, process or service by trade name, trademark, manufacturer, or otherwise does not necessarily constitute or imply its endorsement, recommendation, or favoring by the United States Government or any agency thereof. The views and opinions of authors expressed herein do not necessarily state or reflect those of the United States Government or any agency thereof.

This report has been reproduced directly from the best available copy.

Available for sale to the public, in paper, from: U.S. Department of Commerce, National Technical Information Service, 5285 Port Royal Road, Springfield, VA 22161

phone: (800) 553-6847

fax: (703) 605-6900

email: orders@ntis.fedworld.gov

online ordering: http://www.ntis.gov/ordering.htm

Available electronically at http://www.doe.gov/bridge

Available for a processing fee to U.S. Department of Energy and its contractors, in paper, from: U.S. Department of Energy, Office of Scientific and Technical Information, P.O. Box 62, Oak Ridge, TN 37831-0062

phone: (865)576-8401

fax: (865) 576-5728

email: reports@adonis.osti.gov 


\section{DISCLAIMER}

Portions of this document may be illegible in electronic image products. Images are produced from the best available original document. 
Westinghouse

Savannah River Company

Alken, SC 29808
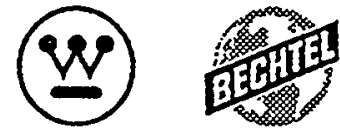

ses

BNFL

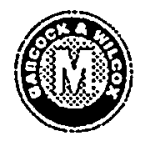

WSRC-RP-99-00111-TL, Revision 0

Keywords: DWPF, Chemical Process Cell, Increased Batch, Sludge, Tank 42

Retention: Permanent

October 19, 1999

M. N. Brosee, Program Manager

Waste Disposition

Attn: W. D. Kerley

Task Initiator: M. R. Norton

\section{INCREASED CHEMICAL PROCESS CELL (CPC) BATCH SIZE STUDY FOR TANK 42 SLUDGE IN THE DEFENSE WASTE PROCESSING FACULITY (DWPF) (U)}

A series of experiments have been completed at TNX for the sludge-only REDOX adjusted flowsheet using Tank 42 sludge simulant in response to the Technical Task Request HLW/DWPT/TTR-980013 to increase CPC batch sizes. By increasing the initial SRAT batch size, a melter feed batch at greater waste solids concentration can be prepared and thus increase melter output per batch by about one canister. The increased throughput would allow DWPF to dispose of more waste in a given time period thus shortening the overall campaign.

For the bench-scale experiments performed, hydrogen generation exceeds DWPF limits only when too much acid (340\%) is added. Nitrite destruction may be a problem for a nominal acid addition of $155 \%$. The required acid stoichiometry appears to be between $155 \%$ and $170 \%$. The absence of an initial acid addition before concentrating (Pre-Boiling Acid Addition) does not appear to present any processing problems. However, because of the small scale of these experiments, potential problems such as mixing and/or heat transfer could not be quantified.

More experiments are necessary to properly quantify the operating conditions for an increased CPC batch but the current evidence does show it is feasible.

If you have additional questions regarding the attached report, please contact W. E. Daniel, 7-7759.

Ewtoctzaheite

E. W. Holtzscheiter, Manager

SRTC - Immobilization Technology Section 
WSRC-TR-99-00111, Rev. 0

\section{INCREASED CPC BATCH SIZE STUDY FOR TANK 42 SLUDGE IN THE DEFENSE WASTE PROCESSING FACILITY (DWPF) (U)}

W. E. Daniel

Westinghouse Savannah River Company

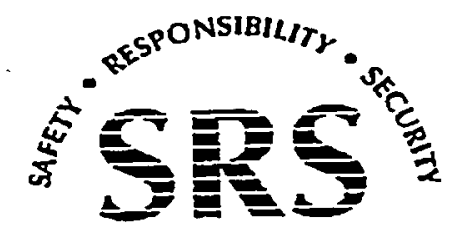




\section{DISCLAIMER}

This report was prepared by Westinghouse Savannah River Company (WSRC) for the United States Department of Energy under Contract No. DE-AC09-96SR18500 and is an account of work performed under that contract. Neither the United States Department of Energy, nor WSRC, nor any of their employees makes any warranty, expresses or implied, assumes any legal liability or responsibility for accuracy, completeness, or usefulness, of any information, apparatus, or product or process disclosed herein or represents that its use will not infringe privately owned rights. Reference herein to any specific commercial product, process, or service by trademark, name, manufacturer or otherwise does not necessarily constitute or imply endorsement, recommendation, or favoring of same by WSRC or by the United States Government or any agency thereof. The views and opinions of the authors expressed herein do not necessarily state or reflect those of the United States Government or any agency thereof. 
WSRC-TR-99-00111, Rev. 0 Distribution Category: To Be Determined

Keywords: DWPF, CPC, Increased Batch, Sludge, Tank 42

Retention: Permanent

\section{INCREASED CPC BATCH SIZE STUDY FOR TANK 42 SLUDGE IN THE DEFENSE WASTE PROCESSING FACILITY (DWPF) (U)}

W. E. Daniel

Publication Date: September 30, 1999

Westinghouse Savannah River Company

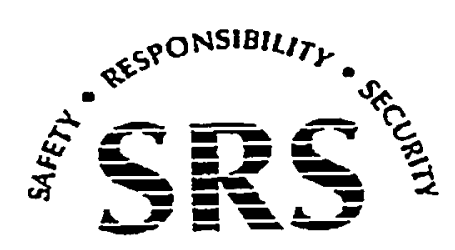




\section{APPROVALS}

t. 2 .

W. E. Daniel, Author

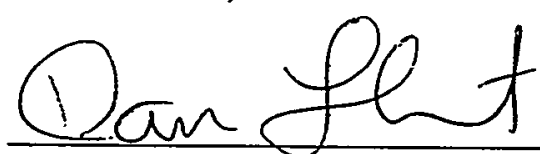

D. P. Lambert, Technical Reviewer

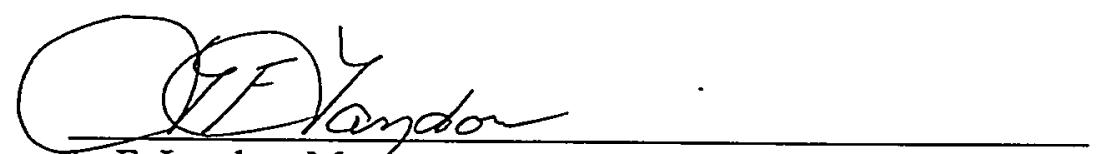

L.F. Landon, Magrager

\section{Euttactizchetu}

E. W. Holtzscheiter, Manager, Immobilization Technology Section

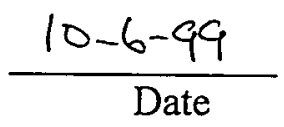

$$
\frac{10-7-99}{\text { Date }}
$$

$\frac{10-15-99}{\text { Date }}$

$\frac{10-18-99}{\text { Date }}$ 


\section{EXECUTIVE SUMMARY}

A series of experiments have been completed at TNX for the sludge-only REDOX adjusted flowsheet using Tank 42 sludge simulant in response to the Technical Task Request HLW/DWPT/TTR-980013 to increase CPC batch sizes. By increasing the initial SRAT batch size, a melter feed batch at greater waste solids concentration can be prepared and thus increase melter output per batch by about one canister. The increased throughput would allow DWPF to dispose of more waste in a given time period thus shortening the overall campaign. In these experiments the following parameters were varied:

- Wt $\%$ Total Solids in Sludge feed: $20 \%$ and $22 \%$

- SRAT Heel Volume: $1200 \mathrm{gal}$ and $1500 \mathrm{gal}$

- Pre-Boiling Acid Addition without measurement/calculation: 133 gal and 0 gal

- Total Stoichiometric Acid Requirement: $340 \%, 197 \%, 175 \%, 170 \%$, and $155 \%$

Hydrogen generation exceeds DWPF limits only when too much acid (340\%) is added. Nitrite destruction may be a problem for a nominal acid addition of $155 \%$. The required acid stoichiometry appears to be between $155 \%$ and $170 \%$. The absence of an initial acid addition before concentrating (Pre-Boiling Acid Addition) does not appear to present any processing problems. However, because of the small scale of these experiments, potential problems such as mixing and/or heat transfer could not be quantified.

The processing problems observed during the bench scale tests with the increased $\mathrm{CPC}$ batch (extra 1000 gal of sludge) are summarized below:

1. Nitrite destruction: Increased acid stoichiometry to compensate. Could boil longer.

2. Keeping slurry well-mixed especially during nitric acid addition: Increased mixing speed to compensate.

3. Pulling samples during SRAT cycle: Slurry very thick so must keep sampler clean to prevent blockage.

Despite these processing problems during the bench scale experiments, it appears DWPF could increase the solids content of a melter feed batch provided:

1. More acid is used (more than $155 \%$ but less than $170 \%$ )

2. DWPF mixing systems are capable of adequately mixing the higher solids slurry

3. Heat transfer coefficients do not fall below an unacceptable level

More experiments are necessary to properly quantify the operating conditions for an increased CPC batch. 


\section{FUTURE WORK}

It is recommended that a series of bench-scale runs be completed with a total weight percent solids sludge closer to the current operating point ( $17 \mathrm{wt}-\%)$ and with acid stoichiometries ranging between $155 \%$ and $300 \%$. These experiments would narrow the acid addition envelope required for an increased CPC batch operation. Since over acidification may exceed DWPF hydrogen safety limits, it is important to properly characterize the upper end of the acid stoichiometry.

Due to the small scale of the bench-scale experiments, a complete rheological profile of the sludge batch and the potential impact on coil fouling and heat transfer are not readily obtainable. Therefore, it is recommended that a melter feed process simulation at the greater solids content per batch be conducted in the Glass Feed Preparation System (GFPS - $1 / 240^{\text {th }}$ scale SRAT) at the optimum processing parameters developed in the bench-scale experiments. In the GFPS, a complete profile of the'rheological properties of the slurry through out the SRAT/SME cycles may be obtained along with on-line measurement of heat transfer coefficients. In addition, an assessment of (1) the DWPF mixing systems to maintain a homogeneous slurry of the SME product and (2) the Hydraguard sampler's ability obtain a representative sample can be evaluated.

These additional experiments could also be designed to determine why proportionally more acid is needed to destroy nitrite as the batch's weight percent solids increase. Additional research should be done into the basis for the required acid calculation for some unknown variable or variables that are not being taken into consideration. 
Westinghouse Savannah River Company

Savannah River Technology Center
WSRC-TR-99-00111, Rev. 0

Page vii of $x$

\section{TABLE OF CONTENTS}

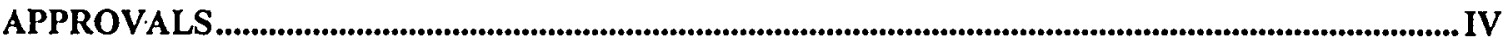

EXECUTIVE SUMMARY .........................................................................................................................................

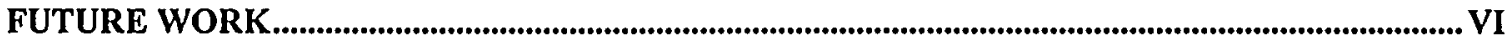

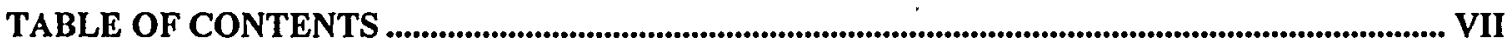

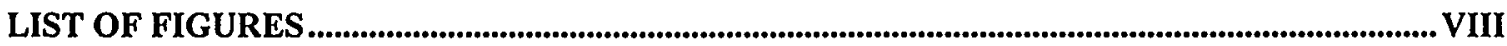

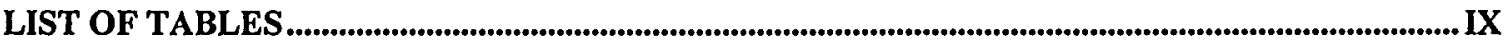

BACKGROUND .................................................................................................................................................... 1

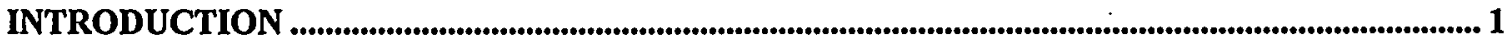

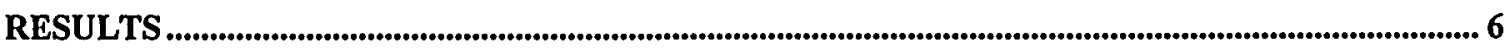

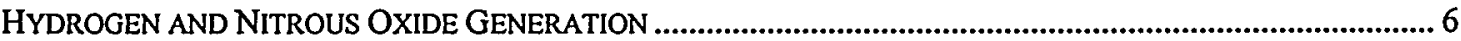

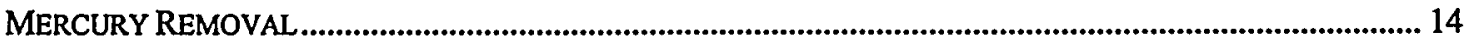

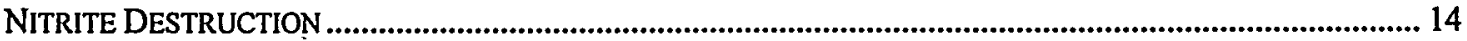

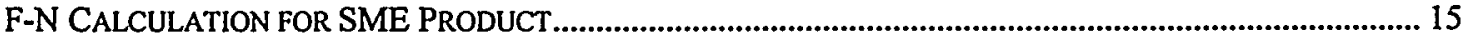

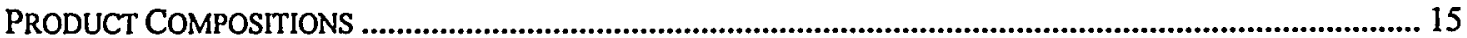

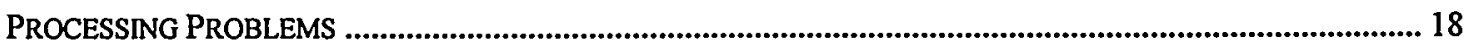

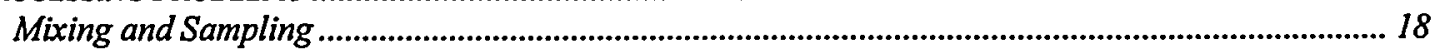

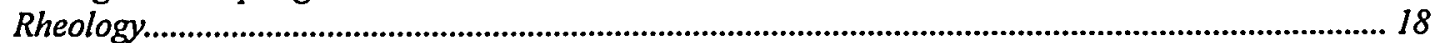

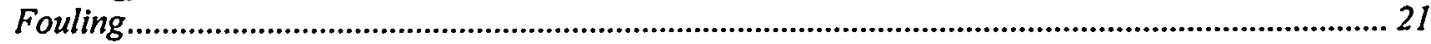

CONCLUSIONS................................................................................................................................................. 24

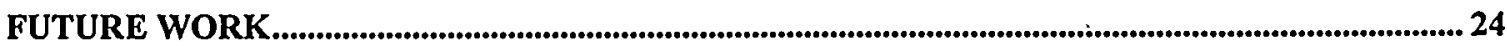

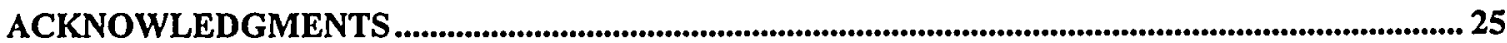

APPENDIX A-1: LARGE BATCH SRAT HEEL PREPARATION ..................................................2 26

APPENDIX A-2: LARGE BATCH SRAT HEEL PREPARATION 2 ..................................................... 35

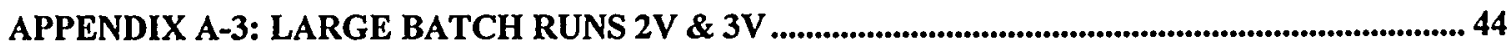

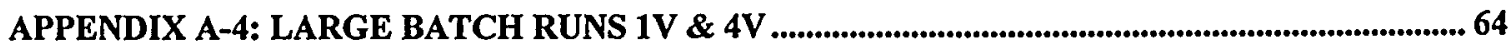

APPENDIX A-5: LARGE BATCH RUNS 5V ....................................................................................... 84

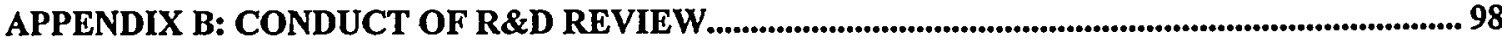




\section{LIST OF FIGURES}

Figure 1. Large CPC Batch Run 1V GC, Nitrite, Formate, and Nitrate Data................................9

Figure 2. Large CPC Batch Run 2V GC, Nitrite, Formate, and Nitrate Data...............................10

Figure 3. Large CPC Batch Run 3V GC, Nitrite, Formate, and Nitrate Data..............................11

Figure 4. Large CPC Batch Run 4V GC, Nitrite, Formate, and Nitrate Data...............................12

Figure 5. Large CPC Batch Run 5V GC, Nitrite, Formate, and Nitrate Data..............................13

Figure 6. Shear Stress versus Rate for SRAT 1V and 3V Products on TA Instruments..............20

Figure 7. Shear Stress versus Rate for SRAT Products on Haake Rheometer...............................20

Figure 8. Large Batch 3V versus Normal Batch Tank 42 \& LB Heel SRAT Rheology..............21

Figure 9. Cooling Dip Leg and Thermocouple for Large CPC Batch Run 1V.............................22

Figure 10. Cooling Dip Leg for Large CPC Batch Run 2V.....................................................22

Figure 11. Cooling Dip Leg for Large CPC Batch Run 3V.........................................................23

Figure 12. Cooling Dip Leg and RTD for Large CPC Batch Run 3V............................................23 
Westinghouse Savannah River Company

Savannah River Technology Center

WSRC-TR-99-00111, Rev. 0

Page ix of $x$

\section{LIST OF TABLES}

Table I.

Table II.

Table III.

Table IV.

Table V.

Table VI.

Table VII.

Table VIII.

Table IX.

Table X.

Table XI.

Table XII.

Table XIII.

Table XIV.

Table XV.

Table XVI.

Table XVII.

Table XVIII.

Table XIX.

Table XX.

Table XXI.

Table XXII.

Table XXIII.

Table XXIV.

Table XXV.

Table XXVI.

Table XXVII.

Table XXVIII.

Table XXIX.

Table XXX.

Table XXXI.

Table XXXII.

Table XXXIII.

Table XXXIV.

Table XXXV.

Table XXXVI.

Table XXXVII.

Table XXXVIII.

Table XXXIX.

Table XL.

Table XLI.

Table XLII.

Table XLIII.
Large CPC Batch Variability Runs

Maximum Hydrogen and Nitrous Oxide Generation for Large CPC Batch 6

Noble Metal Under Addition

Run 4V and 5V Hydrogen Generation

Mercury Removal for Large CPC Batch

Nitrite Destruction for Large CPC Batch

SME Product [F-N] Values for Large CPC Batch

Total and Elemental Weight Percent Solids for SRAT Product

Total and Elemental Weight Percent Solids for SME Product

Mixer Speeds for Large Batch Runs

Yield Stress and Apparent Viscosity for SRAT Products

Coil Fouling for Large CPC Batch

Preparation Of Tank 42 Sludge 20 weight \% (Trim Chemicals Missing)

Elemental Analyses of Large Batch 20 wt\% Sludge A'

Trim Chemical Addition for Large Batch SRAT Heel Preparation

Scaling Calculations for Large Batch SRAT Heel Preparation *

Large Batch SRAT Heel Preparation Redox Calculation

Preparation Of Tank 42 Sludge 20 weight \% (Trim Chemicals Missing)

Elemental Analyses of Large Batch $20 \mathrm{wt} \%$ Sludge $\mathrm{A}^{\prime}$

Trim Chemical Addition for Large Batch SRAT Heel 2 Preparation

Scaling Calculations for Large Batch SRAT Heel 2 Preparation

Large Batch SRAT Heel Preparation Redox Calculation

Preparation Of Tank 42 Sludge 20 weight \% (Trim Chemicals Missing) 45

Elemental Analyses of Large Batch $20 \mathrm{wt} \%$ Sludge $\mathrm{A}^{\prime}$

Elemental Analyses of Large Batch 20.4 wt\% SRAT Heel prepared from Sludge A' 46

Trim Chemical Addition for First Sludge Addition for Run 2V 47

Trim Chemical Addition for Second Sludge Addition for Run 2V 47

Trim Chemical Addition for First Sludge Addition for Run 3V 48

Trim Chemical Addition for Second Sludge Addition for Run 3V 48

Batching Summary for Variability Runs 2V and 3V 49

Scaling Calculations for Large Batch Variability Runs 2V and 3V 50

Large Batch Variability Run 2V Redox Calculation $\quad 51$

Large Batch Variability Run 3V Redox Calculation 53

Preparation Of Tank 42 Sludge 22 weight \% (Trim Chemicals Missing) 65

Elemental Analyses of Large Batch 22 wt\% Sludge B' 65

Elemental Analyses of Large Batch 20.4 wt\% SRAT Heel 66

Trim Chemical Addition for First Sludge Addition for Run 1V 67

Trim Chemical Addition for Second Sludge Addition for Run 1V 67

Trim Chemical Addition for First Sludge Addition for Run 4V 68

Trim Chemical Addition for Second Sludge Addition for Run 4V 68

Batching Summary for Variability Runs 1V and 4V 69

Scaling Calculations for Large Batch Variability Runs 1V and 4V 70

Large Batch Variability Run 1V Redox Calculation 


\section{LIST OF TABLES (continued)}

Table XLIV. Large Batch Variability Run 4V Redox Calculation

Table XLVI. Elemental Analyses of Large Batch $20 \mathrm{wt} \%$ Sludge A'

Table XLVII. Estimated Elementals for Second SRAT Heel prepared from Sludge A' 86

Table XLVIII. $\quad$. Trim Chemical Addition for First Sludge Addition for Run LB 5V

Table XLIX. $\quad$ Trim Chemical Addition for Second Sludge Addition for Run LB 5V 87

Table L. Batching Summary for Variability Run LB 5V

Table LI. Scaling Calculations for Large Batch Variability Runs 5V

Table LII. 
Westinghouse Savannah River Company

Savannah River Technology Center
WSRC-TR-99-00111, Rev. 0

Page 1 of 111

\section{BACKGROUND}

This work is in response to the DWPF Technical Task Request HLW/DWPT/TTR-980013 for developing strategies for increased CPC batch sizes. The Defense Waste Processing Facility (DWPF) wants to increase the batch sizes in its Chemical Processing Cell (CPC) to increase throughput or glass production per batch. DWPF would like to increase the number of canisters per SME cycle or to increase the SME to MFT batch size. By increasing the CPC batch size, higher melter feed solids can be prepared per batch and thus melter output per batch would increase by about one canister. The increased throughput would allow DWPF to dispose of more waste in a set amount of time thus shortening its overall campaign.

The current sludge batch being processed by DWPF is from Tank 42 . Due to delays of In Tank Precipitation (ITP) ${ }^{1}$, an alternative sludge-only REDOX adjusted flowsheet has been developed ${ }^{2}$. Testing has been completed that demonstrates that this sludge-only REDOX process is feasible ${ }^{2}$ for Tank 42 sludge. Based on the findings from this study, a series of Large Batch experiments were recommended that use this particular flowsheet.

A non-radioactive sludge simulant of Tank 42 was used for this study. Conservative Tank 42 levels of mercury and noble metals were targeted. The experiments were completed using a Tank 42 simulant prepared by trimming the Tank 51 simulant with aluminum, mercury, nickel, manganese, and noble metals.

This report documents the results from lab scale experiments to examine the technical feasibility of increasing the CPC batch size in DWPF.

\section{INTRODUCTION}

The objective of this study was to complete a series of laboratory scale experiments to simulate the SRAT and SME processing conditions for increasing the CPC batch size. DWPF had many concerns about the increased $\mathrm{CPC}$ batch process including hydrogen and nitrous oxide generation rates, SRAT coil fouling, the best acid addition strategy for the SRAT, boiling a caustic sludge, and the rheology of materials produced. To address these concerns, the following parameters were monitored during the bench-scale experiments:

- Maximum hydrogen generation rate during the SRAT and SME cycles.

- Maximum nitrous oxide $\left(\mathrm{N}_{2} \mathrm{O}\right)$ generation rate during the SRAT and SME cycles.

- Minimum time necessary for steam stripping mercury to reach the $0.45 \mathrm{wt} \%$ limit in the SRAT product.

- Nitrite destruction rate during the SRAT cycle.

- Any process problems such as foaming, excessive offgas deposits leading to plugging, coil fouling, etc.

- Rheology of SRAT product

\footnotetext{
' D. M. Ferrara, B. C. Ha, D. P. Lambert, and N. E. Bibler, Technical Assessment of a Sludge-only Frit 200 Flowsheet with Copper (U), WSRC-RP-96-142, June 7, 1996.

${ }^{2}$ D. P. Lambert and C. S. Boley, Alternative Tank 51 Sludge-Only Process Development for the Defense Waste Processing Facility (DWPF) (U), WSRC-RP-97-40, Rev.1, March 13, 1997.
} 
The bench-scale experiments were performed in glassware setup at TNX specifically fabricated to replicate the various DWPF processing vessels. These apparatus can simulate the following DWPF vessels: the Sludge Receipt and Adjustment Tank (SRAT)/ Slurry Mix Evaporator (SME), the SRAT/SME condenser, the Formic Acid Vent Condenser (FAVC), the Mercury Water Wash Tank (MWWT), and the Slurry Mix Evaporator Condensate Tank (SMECT).

After consultation with DWPF, the following strategy was decided upon for experimenting with increasing CPC batch size. A normal sludge. transfer of 6000 gallons with 1000 gallons of wash water would be transferred into the SRAT with a 1200 to 1500 gallon heel. Any "Pre-Boiling Acid" would be added at this point, if desired. An arbitrary value of 133 gallons or $2 / 3$ of the standard 200 gallons of 50-wt\% nitric was chosen as the "Pre-Boiling Acid" amount. The SRAT volume would then be concentrated down to 6000 gallons by boiling. After this initial concentration, an additional 1000 gallons of sludge would be added to the SRAT and the remaining SRAT operations would take place, i.e. nitric and formic acid addition followed by concentration to 6000 gallons followed by refluxing. The appropriate amount of acid was added to meet the Total Acid Target and the $\mathrm{Fe}^{+2} / \mathrm{Fe}_{\text {total }}$ REDOX target of 0.22 . Using this strategy, several bench-scale experiments were planned and carried out as discussed in the next section.

More details about this task can be found in the Task Technical \& QA Plan "Develop Strategy for Increased CPC Batch Size. ${ }^{13}$

${ }^{3}$ W. E. Daniel, Develop Strategy for Increased CPC Batch Size, WSRC-RP-98-00354, Rev. 0, July 1, 1998. 
Westinghouse Savannah River Company

Savannah River Technology Center
WSRC-TR-99-00111, Rev. 0

Page 3 of 111

\section{DISCUSSION}

\section{Variability Experiments}

The basic strategy for these bench-scale runs was to reduce the initial SRAT volume so additional sludge could be added and then processed. There were questions about how to add acid, before and/or after the initial concentration of sludge since boiling caustic sludge can lead to thick, gelatinous sludge. There were concerns about how higher weight percent solids could impact the process since the additional sludge would cause total solids to increase more than usual. There were questions about how the SRAT heel may affect the increased CPC batch, i.e. would a larger heel help by acting as a buffer or hurt the process by causing more processing problems. There was concern over what happens if the entire contents of the formic acid tank were emptied into the SRAT. To help answer these questions, a series of bench-scale experiments $1 \mathrm{~V}$ through $5 \mathrm{~V}$ were designed as described below.

1V. This first run was to be a bounding case where the SRAT sludge weight percent solids was high (22\%) and no pre-boiling acid was added to the initial sludge transfer of 6000 gallons. A normal heel of 1500 gallons was assumed from a previous SRAT batch. To satisfy the Total Acid target, a nominal or normal acid addition stoichiometry was planned after the second sludge transfer of 1000 gallons. However, Run $2 \mathrm{~V}$ was completed first and indicated that $155 \%$ stoichiometry was not destroying the nitrite so the value was changed to $197 \%$. This run was to examine processing capabilities for high weight percent sludge with nominal acid addition after initial sludge transfer and concentration. This run was to represent the most expedient processing strategy.

2V. The second run was to emulate a normal batch where a nominal weight percent solids sludge (20\%) was used with a heel of 1500 gallons. A nominal amount of Pre-Boiling acid (50 wt\% nitric acid) was added after the initial sludge transfer of 6000 gallons without any sampling, analyses, or calculations. The Pre-Boiling acid quantity chosen for these experiments was to be 200 gallons based on typical DWPF runs. However, to allow some normal nitric acid addition later in the process, the value was changed to 133 gallons. The goal of this preboiling acid was to avoid boiling a caustic sludge, which has a gel-like consistency and can lower the heat transfer. After the second sludge transfer of 1000 gallons, the acid was added to satisfy the $155 \%$ stoichiometric total acid target.

3V. The third run was to emulate a high acid addition (340\% Stoichiometry) with a nominal sludge (20 wt \% solids) and a low heel (1200 gallons). This study simulated an over acidification of the sludge assuming all the formic acid feed tank was dumped into the SRAT.

4V. The fourth run was to simulate a worst case scenario with low acid addition (137.5\%) with a high weight percent solids sludge and a small heel. In addition, the SRAT volume was to be concentrated below its nominal value (less than 6000 gallons). However, based on the observations from earlier experiments (Run $2 \mathrm{~V}$ and $3 \mathrm{~V}$ ), the post concentration level of the SRAT volume was left at 6000 gallons and the stoichiometry was set at $175 \%$ since $155 \%$ from Run $2 \mathrm{~V}$ did not appear to be destroying the nitrite. 
Westinghouse Savannah River Company

Savannah River Technology Center
WSRC-TR-99-00111, Rev. 0

Page 4 of 111

$5 \mathrm{~V}$. The fifth run was to verify the hydrogen production for a typical DWPF batch with $20 \mathrm{wt} \%$ solids (considered normal at the start of these experiments but now considered high) and a normal heel $(1200 \mathrm{gal})$. This run was a repeat of Run $4 \mathrm{~V}$ but with 20 -wt $\%$ solids sludge and the correct amounts of noble metals.

These runs are summarized in Table I. The first column of Table I shows the run identification while the second column lists the targeted Tank 42 simulant sludge concentration. The third column shows the initial SRAT volume broken down into four component volumes: new sludge, water transferred in with new sludge or other additions, any existing SRAT heel, and the Pre-Boiling Acid or acid added right after the initial sludge transfer without any measurements, samples, or calculations. The next column indicates the SRAT volume after concentration and before reflux. The fifth column shows the amount of additional sludge to transfer into the SRAT after the initial concentration. The last column shows the desired acid requirement in terms of stoichiometric percent to satisfy Total Acid and REDOX targets.

Table I. Large CPC Batch Variability Runs

\begin{tabular}{|c|c|c|c|c|c|c|c|c|}
\hline \multirow[t]{2}{*}{ Run } & \multirow{2}{*}{$\begin{array}{l}\text { Tank } 42 \\
\text { Sludge } \\
\text { Simulant }\end{array}$} & \multicolumn{4}{|c|}{ Initial SRAT Vol. } & \multirow{2}{*}{$\begin{array}{l}\text { SRAT } \\
\text { Vol. } \\
\text { Post } \\
\text { Conc. }\end{array}$} & \multirow{2}{*}{$\begin{array}{c}\text { Add } \\
\text { Sludge } \\
\text { Post } \\
\text { Conc. }\end{array}$} & \multirow{2}{*}{$\begin{array}{c}\text { Acid } \\
\text { Requirement }\end{array}$} \\
\hline & & Sludge & Water & Heel & $\begin{array}{c}\text { Pre- } \\
\text { Boiling } \\
\text { Acid }\end{array}$ & & & \\
\hline \multirow[t]{2}{*}{$1 \mathrm{~V}$} & high wt\% & \multicolumn{4}{|c|}{$8500 \mathrm{gal}$} & \multirow{2}{*}{$\begin{array}{c}6000 \\
\text { gal }\end{array}$} & \multirow{2}{*}{$\begin{array}{c}1000 \\
\text { gal }\end{array}$} & \multirow{2}{*}{$\begin{array}{c}197 \% \\
\text { Stoichiometry* }\end{array}$} \\
\hline & solids $(22 \%)$ & 6000 & 1000 & 1500 & 0 & & & \\
\hline \multirow[t]{2}{*}{$2 \mathrm{~V}$} & normal wt\% & \multicolumn{4}{|c|}{$8700 \mathrm{gal}$} & \multirow{2}{*}{$\begin{array}{c}6000 \\
\text { gal }\end{array}$} & \multirow{2}{*}{$\begin{array}{c}1000 \\
\text { gal }\end{array}$} & \multirow{2}{*}{$\begin{array}{c}155 \% \\
\text { Stoichiometry }\end{array}$} \\
\hline & solids (20\%) & 6000 & 1000 & 1500 & $133^{*}$ & & & \\
\hline \multirow[t]{2}{*}{$3 \mathrm{~V}$} & normal wt $\%$ & \multicolumn{4}{|c|}{$8200 \mathrm{gal}$} & \multirow{2}{*}{$\begin{array}{c}6000 \\
\text { gal }\end{array}$} & \multirow{2}{*}{$\begin{array}{c}1000 \\
\text { gal }\end{array}$} & \multirow{2}{*}{$\begin{array}{c}340 \% \\
\text { Stoichiometry }\end{array}$} \\
\hline & solids $(20 \%)$ & 6000 & 1000 & 1200 & 0 & & & \\
\hline \multirow[t]{2}{*}{$4 \mathrm{~V}$} & high wt\% & \multicolumn{4}{|c|}{$8200 \mathrm{gal}$} & \multirow{2}{*}{$\begin{array}{l}6000 \\
\text { gal* }^{*}\end{array}$} & \multirow{2}{*}{$\begin{array}{c}1000 \\
\mathrm{gal}\end{array}$} & \multirow{2}{*}{$\begin{array}{c}175 \% \\
\text { Stoichiometry* }\end{array}$} \\
\hline & solids ( $22 \%)$ & 6000 & 1000 & 1200 & $\overline{0}$ & & & \\
\hline \multirow[t]{2}{*}{$5 \mathrm{~V}$} & normal wt\% & \multicolumn{4}{|c|}{$8200 \mathrm{gal}$} & \multirow{2}{*}{$\begin{array}{c}6000 \\
\text { gal }\end{array}$} & \multirow{2}{*}{$\begin{array}{c}1000 \\
\text { gal }\end{array}$} & \multirow{2}{*}{$\begin{array}{c}170 \% \\
\text { Stoichiometry* }\end{array}$} \\
\hline & solids (20\%) & 6000 & 1000 & 1200 & 0 & & & \\
\hline
\end{tabular}

Some of the values in Table I changed from their original specifications due to early experiments and observations. The acid requirement in Run $1 \mathrm{~V}$ was increased from a targeted $155 \%$ to $197 \%$ when no evidence of hydrogen was seen in Run $2 \mathrm{~V}$. The target acid requirement for Run $4 \mathrm{~V}$ was increased to $175 \%$ since $155 \%$ did not seem sufficient for nitrite destruction. After these adjustments it was discovered that the noble metals had been under added in Runs $1 \mathrm{~V}$ through $4 \mathrm{~V}$. This low noble metal addition was one of the reasons for the low hydrogen generation. Another bench-scale run (5V) was done with the correct amount of noble metals to re-examine the hydrogen generation.

During these experiments, slurry $\mathrm{pH}$, offgas hydrogen, $\mathrm{N}_{2} \mathrm{O}$, and $\mathrm{CO}_{2}$ concentrations, as well as flow rates were measured. Samples were pulled every two hours to monitor the nitrite, nitrate, and formate concentrations in the slurry. The "nominal" sludge used in each of these runs contained approximately $20 \mathrm{wt} \%$ solids as at the time this work was done that represented the expected weight percent solids for Tank 42. From current measurements, Tank 42 is closer to $17 \mathrm{wt} \%$ solids. Acid additions were based on the total acid to achieve the proper acid stoichiometry. Concentrated formic 
acid (90 wt\%) and nitric acid (50 wt\%) were used during processing. In addition, Dow Corning 544 antifoam was added per the DWPF antifoam strategy (100 ppm on a total solution basis, 1 part antifoam:19 parts water).

All these experiments followed the sludge-only REDOX adjusted flowsheet ${ }^{2}$ where the acid requirement is determined by a correlation developed by Kevin Brown ${ }^{4}$. Although the adjusted REDOX flowsheet was used, REDOX was not to be measured (only predicted) since glass quality was not the target of this investigation. However, [F-N] values are reported to gauge melter feed against past DWPF results. During these experiments the items of concern listed earlier, like $\mathrm{H}_{2}$ and $\mathrm{N}_{2} \mathrm{O}$ generation were monitored, as the results will show.

\section{Experimental Setup and Preparation}

Before the Large Batch experiments could begin, a SRAT heel had to be prepared. Details of this SRAT heel preparation for Runs $1 \mathrm{~V}$ through $4 \mathrm{~V}$ are contained in Appendix A-1. Due to usage of all the first heel, another heel had to be prepared for Run 5V, which is discussed in Appendix A-2. In summary, the SRAT Heel was created from the Optima Tank 51 simulant trimmed with Tank 42 levels of noble metals and mercury. A 20-weight percent solids sludge was targeted after the addition of trim chemicals (noble metals and mercury). This sludge was referred to as Sludge $\mathrm{A}^{\prime}$ and its pretrim measured as well as post-trim predicted elemental weight percent analyses are shown in Tables I and II in Appendix A-1 and Table XVIII and Table XIX in Appendix A-2. This sludge required approximately 12 hours of refluxing in the SRAT to steam strip mercury and meet the DWPF constraint of $0.45 \mathrm{wt} \%$ mercury.

Details of the large batch variability experiments $2 \mathrm{~V}$ and $3 \mathrm{~V}$ are contained in Appendix. A-3. Runs $1 \mathrm{~V}$ and $4 \mathrm{~V}$ are documented in Appendix A-4. Run $5 \mathrm{~V}$ is described in Appendix A-5. In summary, a 4-liter glass vessel was used to simulate the SRAT/SME tanks of DWPF. The lab scale setup included a $10^{\circ} \mathrm{C}$ and a $40^{\circ} \mathrm{C}$ condenser, a Mercury Water Wash Tank, a cooling dip leg, and a Slurry Mix Evaporator Condensate Tank. The lab scale experiments were performed in 772-T lab at TNX and were scaled at $1 / 11,355^{\text {th }}$ DWPF size. More details on these experiments are contained in each of the run plans in Appendix A-3 through A-5.

A copy of the Conduct of $R \& D$ review is contained in Appendix B.

\footnotetext{
${ }^{4}$ K. G. Brown, C. M. Jantzen, and J. B. Pickett, The Effects of Formate and Nitrate on Reduction/Oxidation (REDOX) Process Control for the Defense Waste Processing Facility (DWPF)(U), WSRC-RP-97-34, February 3, 1997.
} 
Westinghouse Savannah River Company

Savannah River Technology Center
WSRC-TR-99-00111, Rev. 0

Page 6 of 111

\section{RESULTS}

\section{Hydrogen and Nitrous Oxide Generation}

One of DWPF chief concerns is that with more sludge there will be more noble metals in each batch. The additional noble metals are expected to increase the amount of hydrogen $\left(\mathrm{H}_{2}\right)$ and nitrous oxide $\left(\mathrm{N}_{2} \mathrm{O}\right)$ being generated during a large $\mathrm{CPC}$ batch. Table II summarizes the maximum hydrogen and nitrous oxide generation observed in vol\% and $\mathrm{lb} / \mathrm{hr}$ at full DPWF scale for both the SRAT and SME cycles in Runs 1V through 5V.

Table II. Maximum Hydrogen and Nitrous Oxide Generation for Large CPC Batch

\begin{tabular}{|c|c|c|c|c|c|c|c|c|}
\hline & \multicolumn{4}{|c|}{ SRAT } & \multicolumn{4}{c|}{ SME } \\
\hline Run & \multicolumn{2}{|c|}{$\mathrm{Max} \mathrm{H}_{2}$} & \multicolumn{2}{c|}{$\mathrm{Max} \mathrm{N}_{2} \mathrm{O}$} & \multicolumn{2}{c|}{$\mathrm{Max} \mathrm{H}_{2}$} & \multicolumn{2}{c|}{$\mathrm{Max} \mathrm{N}_{2} \mathrm{O}$} \\
\hline & $\mathrm{vol} \%$ & $\mathrm{lb}_{\mathrm{hr}}$ & $\mathrm{vol} \%$ & $\mathrm{lb} / \mathrm{hr}^{\dagger}$ & $\mathrm{vol} \%$ & $\mathrm{lb} / \mathrm{hr}^{\dagger}$ & $\mathrm{vol} \%$ & $\mathrm{lb} / \mathrm{hr}^{\dagger}$ \\
\hline 1V & 0.023 & 0.015 & 1.751 & 28.5 & 0.125 & 0.030 & 0.0 & 0.0 \\
\hline 2V & 0.0 & 0.0 & 0.869 & 9.2 & 0.0 & 0.0 & 0.0 & 0.0 \\
\hline 3V & 0.591 & 0.35 & 3.473 & 51.8 & 1.117 & $\mathbf{0 . 2 3}^{\ddagger}$ & 0.0 & 0.0 \\
\hline 4V & 0.002 & 0.001 & 1.319 & 18.6 & 0.026 & 0.005 & 0.0 & 0.0 \\
\hline 5V & 0.013 & 0.009 & 2.401 & 49.9 & 0.076 & 0.021 & 0.0 & 0.0 \\
\hline DWPF Limit & -- & 0.65 & -- & -- & -- & 0.23 & -- & -- \\
\hline
\end{tabular}

${ }^{\mathrm{T}} \mathrm{b} / \mathrm{hr}$ at full DWPF scale, ${ }^{\mathrm{E}}$ Exceeded DWPF hydrogen generation limit

Hydrogen and other gas generation data as well as anion data for Runs $1 \mathrm{~V}$ through $5 \mathrm{~V}$ are shown in Figure 1 through Figure 5, respectively. The top graph of each figure shows all GC and anion data plus mixer speed and torque. The bottom graphs of each figure show the hydrogen generation in pounds per hour for a 6000-gallon DWPF batch. Also in each graph the separate phases of the SRAT/SME cycles are identified by lines and lettering. $D$ represents dewatering, $\mathrm{N}$ stands for Nitric acid addition, $\mathrm{F}$ is formic acid addition, and $\mathrm{R}$ is for reflux. The SRAT cycle ends at the end of the reflux section where upon the SME cycle begins.

After reviewing the sludge trimming done for Runs $1 \mathrm{~V}$ through $4 \mathrm{~V}$, it was discovered that the noble metals $(\mathrm{Pd}, \mathrm{Rh}$, and $\mathrm{Ru})$ were under added. The amount of under addition is summarized in Table III. Due to this under addition, the conditions of Run $4 \mathrm{~V}$ were repeated in Run $5 \mathrm{~V}$ except a 20 -wt\% solids sludge was used instead of a $22-w t \%$ sludge.

Table III. Noble Metal Under Addition

\begin{tabular}{|c|c|c|c|}
\hline Run & $\mathrm{Pd}$ & $\mathrm{Rh}$ & $\mathrm{Ru}$ \\
\hline IV & $280 \%$ & $630 \%$ & $17 \%$ \\
\hline 2V & $250 \%$ & $630 \%$ & $17 \%$ \\
\hline 3V & $240 \%$ & $620 \%$ & $17 \%$ \\
\hline 4V & $280 \%$ & $650 \%$ & $17 \%$ \\
\hline
\end{tabular}

For Run $1 \mathrm{~V}$ the maximum hydrogen generation occurred at the end of the SME cycle at $0.030 \mathrm{lb} / \mathrm{hr}$. This was a momentary peak during the end of the second dewater phase in the SME cycle as shown in Figure 1. This value is artificially low due to the noble metal under addition especially considering the acid added was equivalent to $197 \%$ stoichiometry. However, all the nitrite had been destroyed 
Westinghouse Savannah River Company

Savannah River Technology Center
WSRC-TR-99-00111, Rev. 0

Page 7 of 111

shortly after the reflux cycle started. This data indicates that the noble metal content of the sludge has a big impact on the hydrogen production. The maximum nitrous oxide generation for Run $1 \mathrm{~V}$ was $24.2 \mathrm{lb} / \mathrm{hr}$ and took place in the SRAT cycle at the end of the formic addition and right before the SRAT dewatering phase as shown in Figure 1.

In Run $2 \mathrm{~V}$, there appeared to be no hydrogen generation, which corresponded to the slow destruction of nitrite, $\mathrm{NO}_{2}^{-}$, as shown in Figure 2. It was not until the end of the SME cycle in Run $2 \mathrm{~V}$ that all the nitrite was finally destroyed. The low hydrogen generation can also be attributed to the noble metal under addition. This data shows the impact of the acid addition as all the nitrite is destroyed at the beginning of the SRAT reflux cycle of Run $1 \mathrm{~V}$ with $197 \%$ acid but in Run $2 \mathrm{~V}$ with $155 \%$ acid it is not destroyed until the end of the SME cycle. This run can be furthered compared to an earlier Tank 42 experiment ${ }^{5}$ with $137.5 \%$ acid, 16-wt\% solids sludge, and prototypic Tank 42 levels of noble metals. In this earlier experiment, 5 times as much $\mathrm{Rh}$ was added and the maximum hydrogen generation in the SRAT was $0.004 \mathrm{lb} / \mathrm{hr}$ and in the SME $0.085 \mathrm{lb} / \mathrm{hr}$. Given the larger amount of acid $(155 \%)$ and higher weight percent solids in Run $2 \mathrm{~V}$, the hydrogen generation should be at least as much as that seen in this earlier experiment. The maximum nitrous oxide generation for Run $2 \mathrm{~V}$ was $12.0 \mathrm{lb} / \mathrm{hr}$ and took place in the SRAT cycle at the end of the formic addition and right before the SRAT dewatering phase as shown in Figure 2.

For Run $3 \mathrm{~V}$ the maximum observed hydrogen generation occurred during the reflux stage of the SRAT cycle at $0.35 \mathrm{lb} / \mathrm{hr}$. Although this value is high, it is still artificially low due to the noble metal under addition especially considering the high amount of acid added ( $340 \%$ stoichiometry). To draw a parallel with previous experiments ${ }^{3}$ with 17 -wt\% solids Tank 42 sludge and Tank 42 level of noble metals, a $254 \%$ acid addition gave a maximum of $0.31 \mathrm{lb} / \mathrm{hr}$ hydrogen generation in the SRAT and $0.162 \mathrm{lb} / \mathrm{hr}$ in the SME. In this earlier experiment, more than 5 times as much $\mathrm{Rh}$ had been added to the sludge. Given the higher weight percent solids sludge (20-wt\%) and higher acid addition (340\%) for Run $3 \mathrm{~V}$, the hydrogen generation would probably come close to the DWPF limit of $0.65 \mathrm{lb} / \mathrm{hr}$ or even beyond it. Even with the low noble metal content, Run 3V hydrogen generation in the SME is high enough $(0.23 \mathrm{lb} / \mathrm{hr})$ for the DWPF interlock, i.e. exceeds $25 \% \mathrm{LEL}$. Given the low noble metal content, if a complete dump of the formic acid feed tank did occur, there would be strong concerns for hydrogen generation in the SME although high results are expected because of the extreme amount of acid added. A more normal acid stoichiometry would give a more reasonable hydrogen peak as seen in Run 5V. The maximum nitrous oxide generation for Run $3 \mathrm{~V}$ was $48.5 \mathrm{lb} / \mathrm{hr}$ during the large formic addition phase of the SRAT cycle, as shown in Figure 3.

For Run 4V the maximum observed hydrogen generation occurred at the end of the SME cycle at $0.005 \mathrm{lb} / \mathrm{hr}$. This hydrogen peak occurred at the end of the second dewater phase in the SME cycle as shown in Figure 4. This hydrogen peak is artificially low due to the noble metal addition. However, as shown in the top graph of Figure 4, all the nitrite is destroyed by the end of the SRAT reflux cycle. The maximum nitrous oxide generation for Run $4 \mathrm{~V}$ was $18.3 \mathrm{lb} / \mathrm{hr}$ and took place in the SRAT cycle at the beginning of the SRAT dewatering phase as shown in Figure 4.

For Run $5 \mathrm{~V}$ the maximum hydrogen generation occurred at the end of the SME cycle at $0.021 \mathrm{lb} / \mathrm{hr}$ as shown in Figure 5. The maximum hydrogen generation in the SRAT cycle was $0.009 \mathrm{lb} / \mathrm{hr}$. Since Run $5 \mathrm{~V}$ was to emulate Run $4 \mathrm{~V}$ except with the correct level of noble metals, a simple comparison

${ }^{5}$ D. P. Lambert, C. S. Boley, Tank 42 Sludge-Only Process Development for the Defense Waste Processing Facility (DWPF)(U), WSRC-RP-98-00149, June 2, 1998. 
can be made if one assumes that the hydrogen production depends strictly on the amount of Rhodium $(\mathrm{Rh})$ in the slurry. Please refer to Table IV for a comparison of Run $4 \mathrm{~V}$ and $5 \mathrm{~V}$ hydrogen generation rates. In Run $4 \mathrm{~V}$ the maximum observed hydrogen rate in the SRAT was $0.0013 \mathrm{lb} / \mathrm{hr}$, but linearly correcting for the $650 \% \mathrm{Rh}$ under addition, the maximum hydrogen rate is estimated to be 0.0084 $\mathrm{lb} / \mathrm{hr}$. This correction is over simplified and does not take into account the reaction kinetics but does help to validate Run $5 \mathrm{~V}$ results. If the same type of simple correction is applied to the Run 4V SME maximum of $0.0053 \mathrm{lb} / \mathrm{hr}$, the estimated maximum would be $0.034 \mathrm{lb} / \mathrm{hr}$. Again this value is similar to Run 5V SME maximum considering that Run $5 \mathrm{~V}$ had less initial total solids (20-wt\%) versus Run $4 \mathrm{~V}$ (22-wt\%.). The maximum nitrous oxide generation for Run $5 \mathrm{~V}$ was $49.9 \mathrm{lb} / \mathrm{hr}$ and took place in the SRAT cycle about half way through the SRAT dewatering phase as shown in Figure 5.

Table IV. Run 4V and 5V Hydrogen Generation

\begin{tabular}{|c|c|c|c|}
\hline Run & g Rhodium & SRAT $\mathrm{H}_{2}, \mathrm{lb} / \mathrm{hr}$ & $\mathrm{SME} \mathrm{H}_{2}, \mathrm{lb} / \mathrm{hr}$ \\
\hline $4 \mathrm{~V}$ & 0.00300 & 0.0013 & 0.0053 \\
\hline $5 \mathrm{~V}$ & 0.02125 & 0.0091 & 0.0209 \\
\hline Ratio 5V/4V & 7 & 7 & 4 \\
\hline
\end{tabular}

The following figures represent the $\mathrm{GC}$ and other data collected during the previously described runs. In each figure, the top graphs represent multiple types of data plotted against the same numeric axes. The nitrogen $\left(\mathrm{N}_{2}\right)$, oxygen $\left(\mathrm{O}_{2}\right)$, and carbon dioxide $\left(\mathrm{CO}_{2}\right)$ are in volume percent and plotted versus the right hand axis. The formate $(\mathrm{COOH})$ and nitrate $\left(\mathrm{NO}_{3}{ }^{-}\right)$are in parts per thousand (1 ppt is equivalent to $1000 \mathrm{ppm})$ and plotted against the right axis. The mixer speed divided by ten (RPM/10) and the torque (oz-in) are also plotted against the right axis. Helium (He), hydrogen $\left(\mathrm{H}_{2}\right)$ and nitrous oxide $\left(\mathrm{N}_{2} \mathrm{O}\right)$ are in volume percent and plotted versus the left axis. 

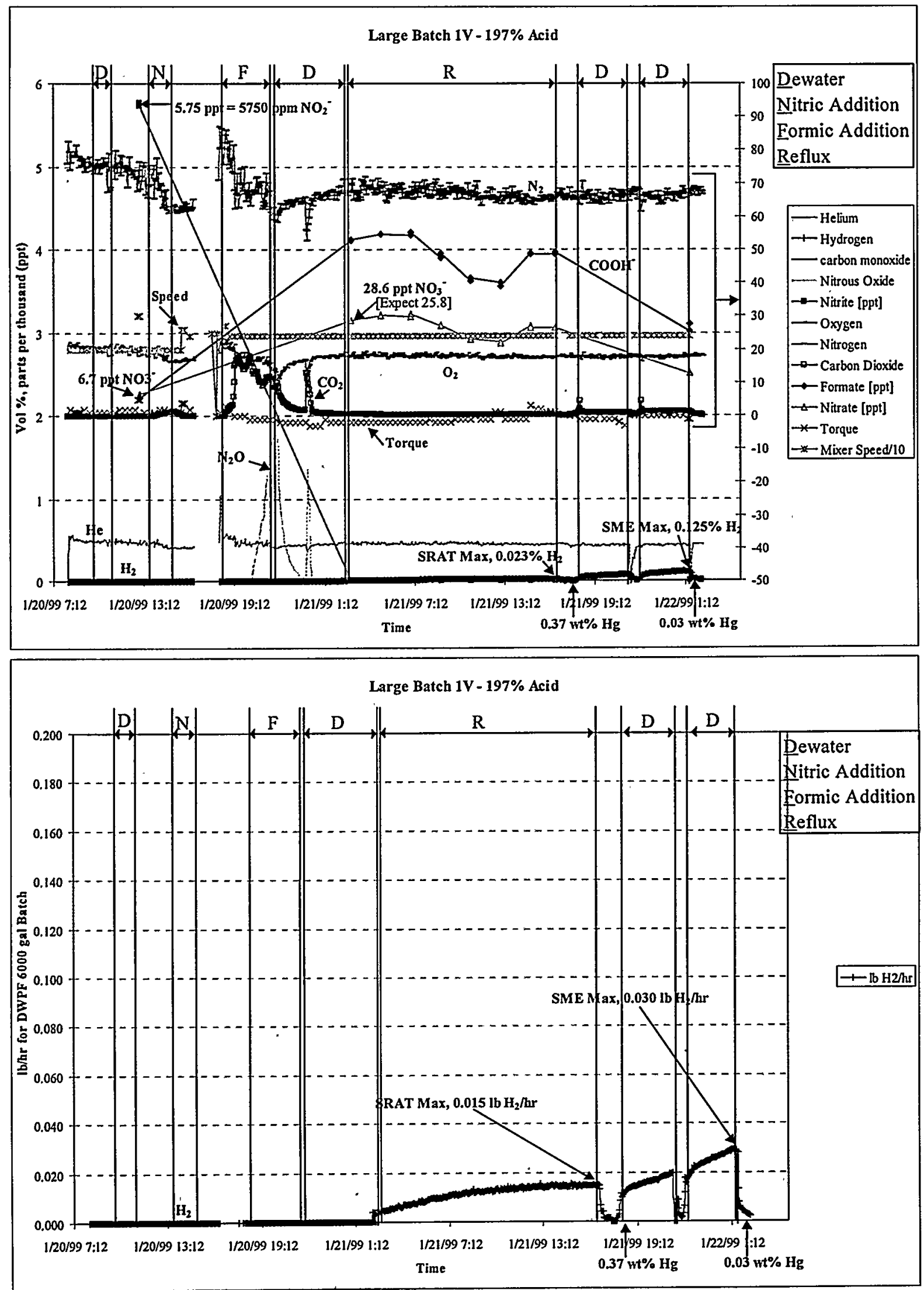

Figure 1. Large CPC Batch Run 1V GC, Nitrite, Formate, and Nitrate Data. 

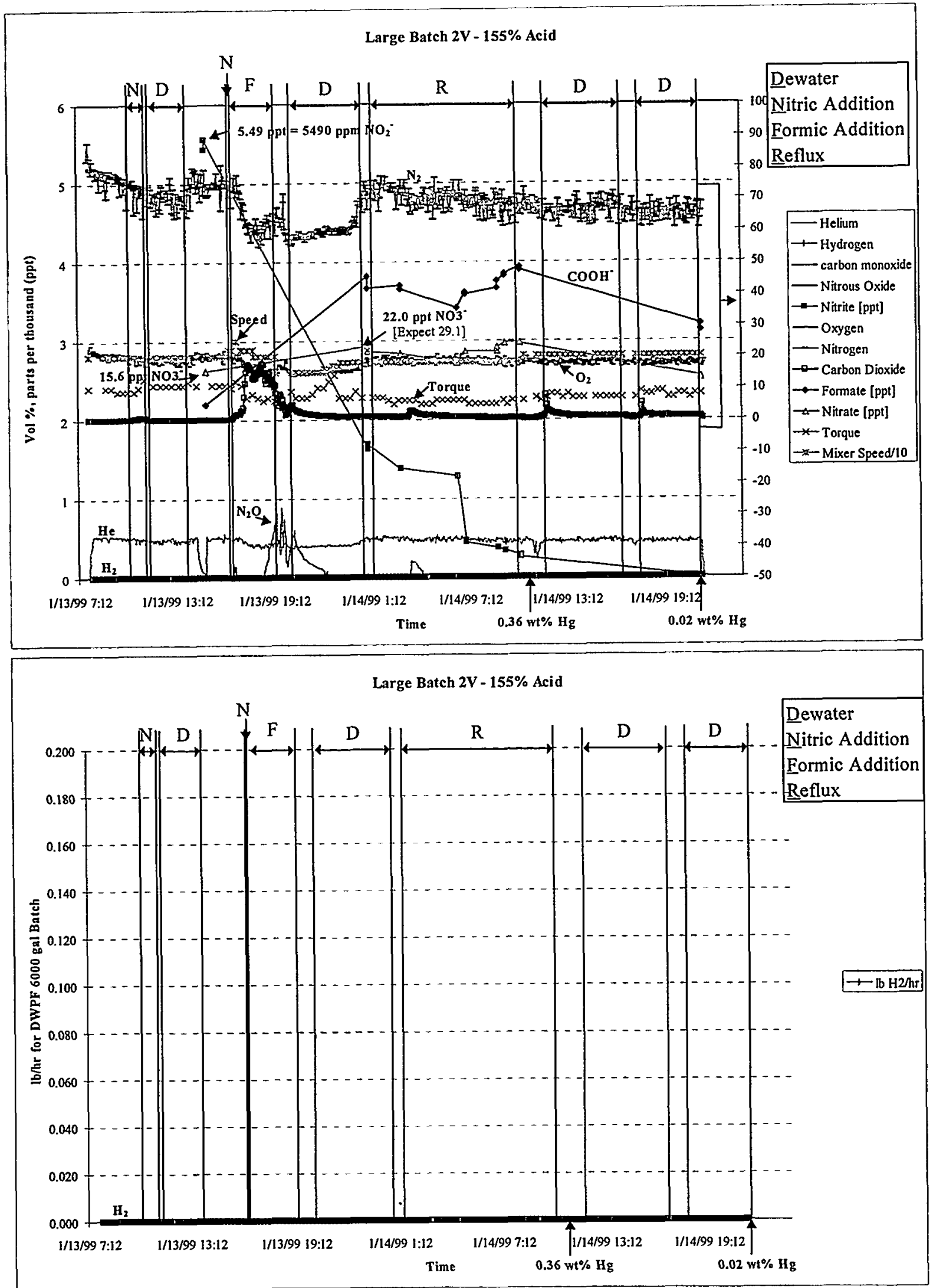

Figure 2. Large CPC Batch Run 2V GC, Nitrite, Formate, and Nitrate Data. 

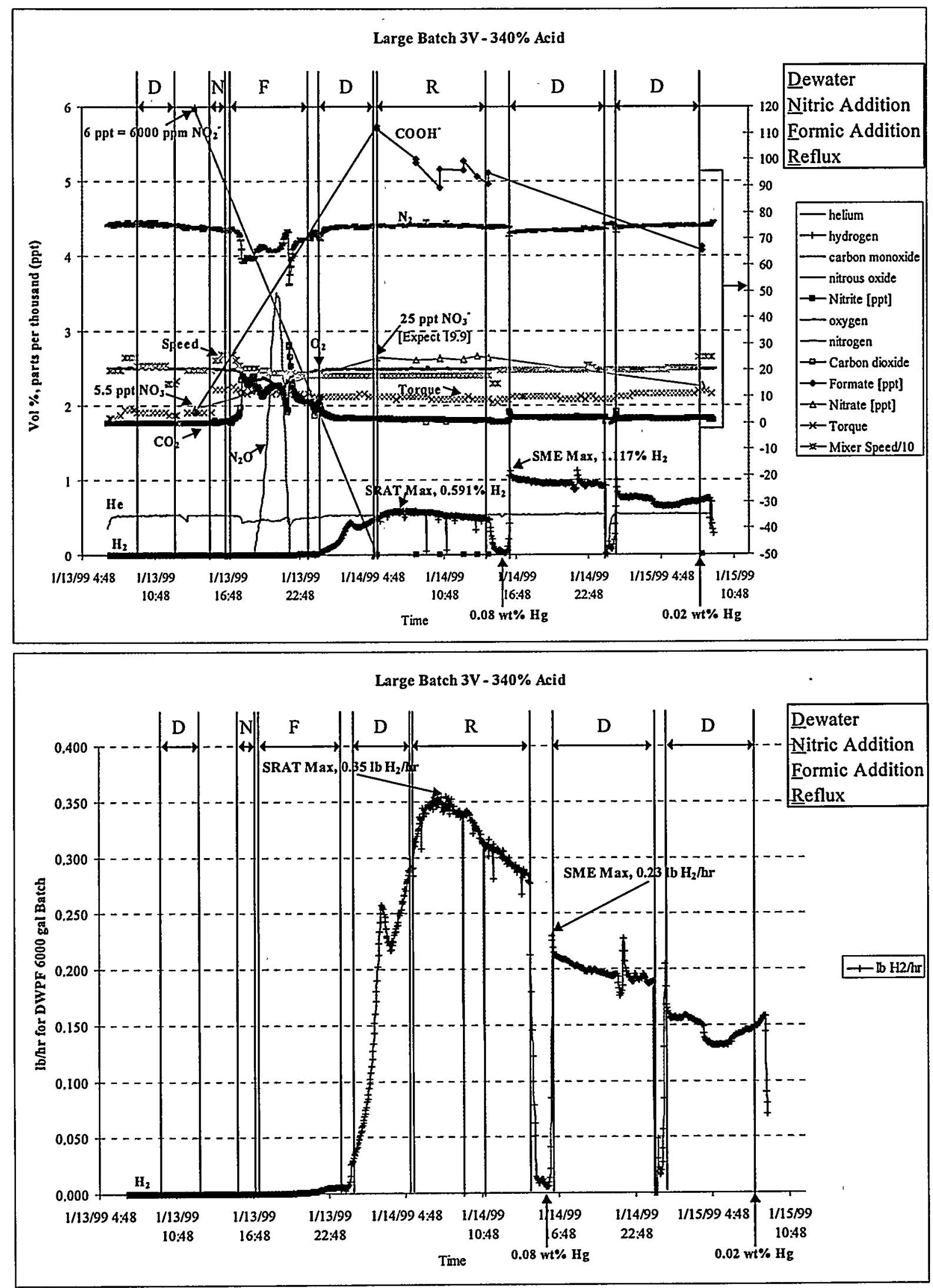

Figure 3. Large CPC Batch Run 3V GC, Nitrite, Formate, and Nitrate Data. 

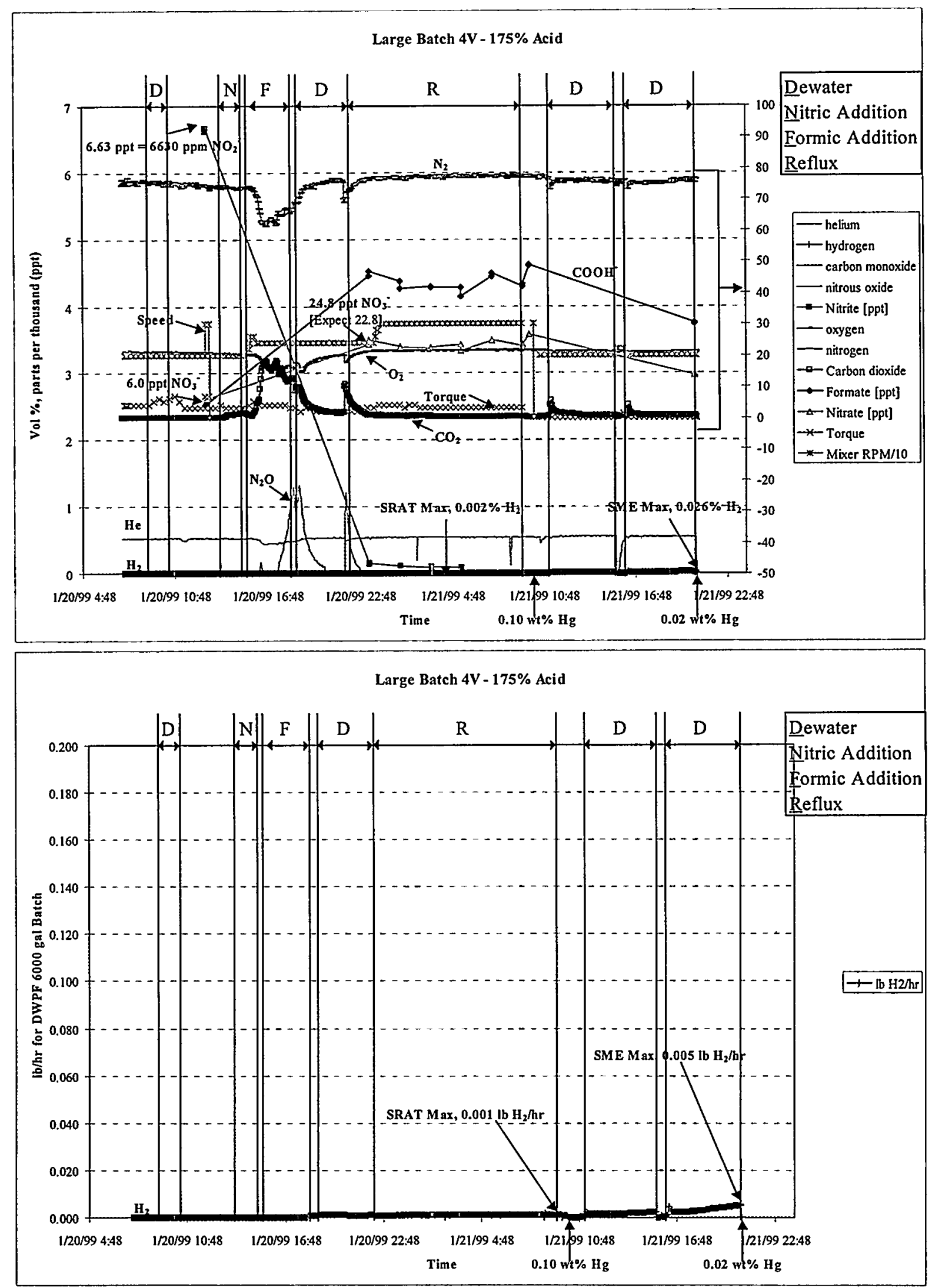

Figure 4. Large CPC Batch Run 4V GC, Nitrite, Formate, and Nitrate Data. 

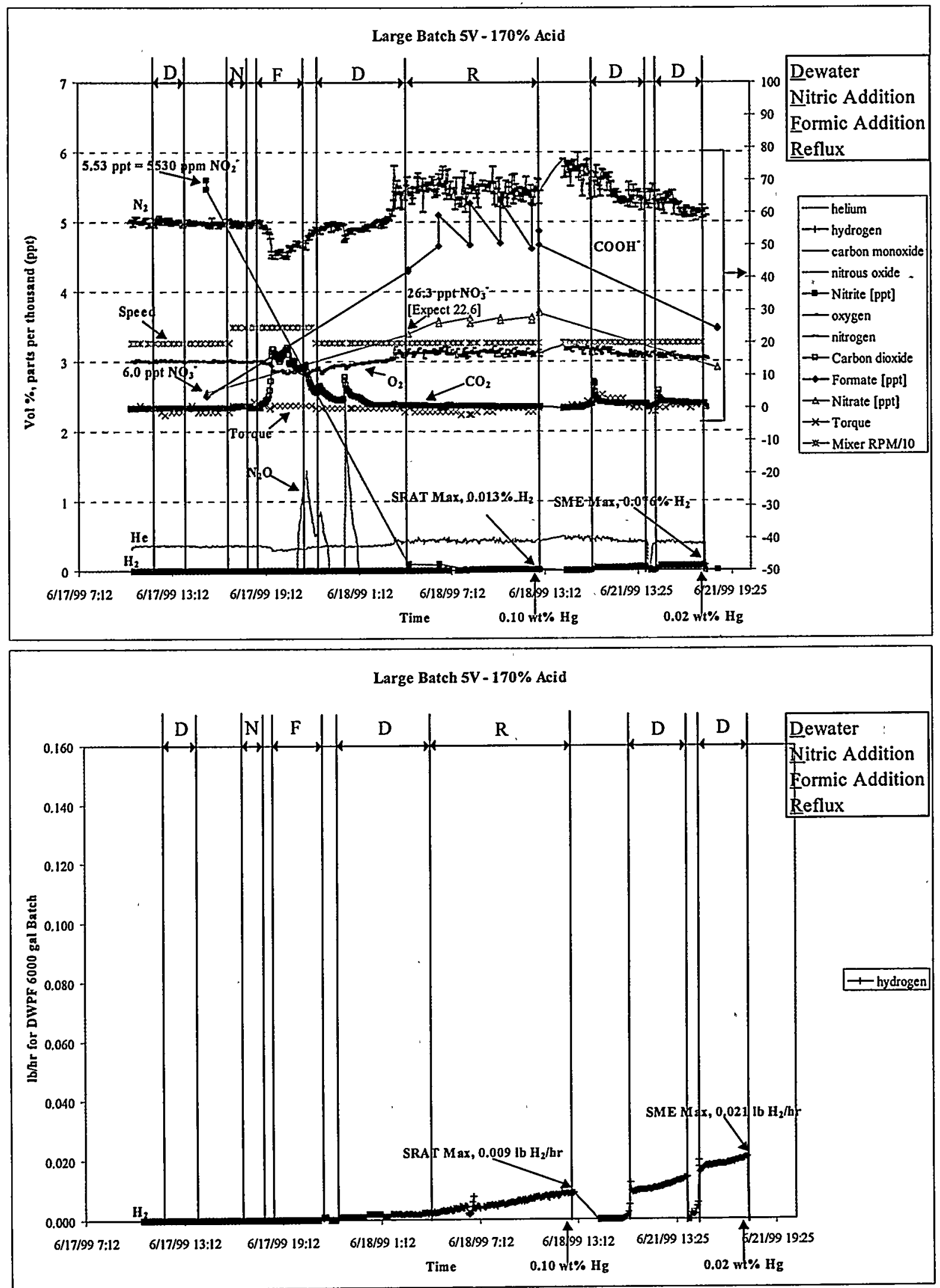

Figure 5. Large CPC Batch Run 5V GC, Nitrite, Formate, and Nitrate Data. 


\section{Mercury Removal}

Another DWPF SRAT processing constraint is the removal of mercury. For Runs $1 \mathrm{~V}$ through $5 \mathrm{~V}$, mercury removal was accomplished beyond $0.45 \mathrm{wt} \%$ by the end of the SRAT cycle as shown in Table V. However, the normal reflux time of 12 hours had to be increased to 14 hours. The extended reflux times listed in Table V included the dewater time of the SRAT cycle plus extra time to see evidence of nitrite destruction or hydrogen generation. As can be seen from Runs $2 \mathrm{~V}, 3 \mathrm{~V}, 4 \mathrm{~V}$, and $5 \mathrm{~V}, 14$ hours of reflux is more than sufficient to remove $\mathrm{Hg}$ down to $0.45 \mathrm{wt} \%$. The mercury analyses were done on the SRAT final samples, which were pulled at the end of the reflux period. The end of the reflux period was defined as the point where hydrogen generation had gone through a maximum providing evidence of nitrite destruction. For this reason, the $\mathrm{Hg}$ measurement for Run $\mathrm{VV}$ occurred at 18 hours instead of the normal 14 hours.

Table V. Mercury Removal for Large CPC Batch

\begin{tabular}{|c|c|c|c|c|}
\hline Run & Stoichiometry & SRAT & SME & Hg Recovered \\
\hline IV & $197 \%$ & $\begin{array}{c}0.37 \mathrm{wt} \% \mathrm{Hg} \\
(18.4 \mathrm{hrs} \mathrm{Reflux})^{6}\end{array}$ & $0.032 \mathrm{wt} \% \mathrm{Hg}$ & $3.8 \mathrm{~g}$ \\
\hline 2V & $155 \%$ & $\begin{array}{c}0.36 \mathrm{wt} \% \mathrm{Hg} \\
(13.5 \mathrm{hrs} \mathrm{Reflux})^{6}\end{array}$ & $0.024 \mathrm{wt} \% \mathrm{Hg}$ & $4.0 \mathrm{~g}$ \\
\hline 3V & $340 \%$ & $\begin{array}{c}0.083 \mathrm{wt} \% \mathrm{Hg} \\
(13.7 \mathrm{hrs} \mathrm{Reflux})^{6}\end{array}$ & $0.024 \mathrm{wt} \% \mathrm{Hg}$ & $3.8 \mathrm{~g}$ \\
\hline 4V & $175 \%$ & $\begin{array}{c}0.098 \mathrm{wt} \% \mathrm{Hg} \\
(14.7 \mathrm{hrs} \mathrm{Reflux})^{6}\end{array}$ & $0.020 \mathrm{wt} \% \mathrm{Hg}$ & $2.8 \mathrm{~g}$ \\
\hline 5V & $170 \%$ & $\begin{array}{c}0.26 \mathrm{wt} \% \mathrm{Hg} \\
(14.3 \mathrm{hrs} \text { Reflux })^{6}\end{array}$ & $0.044 \mathrm{wt} \% \mathrm{Hg}$ & $4.8 \mathrm{~g}$ \\
\hline
\end{tabular}

\section{Nitrite Destruction}

Another DWPF processing goal is the destruction of nitrite $\left(\mathrm{NO}_{2}{ }^{-}\right)$during the SRAT cycle. Table VI summarizes the levels of nitrite right before the addition of nitric acid (pre-nitric), right before reflux (pre-reflux), and right after reflux (post-reflux) in the SRAT cycles of these runs. The nitrite destruction can also be followed in Figure 1 through Figure 5 for Runs $1 \mathrm{~V}$ through $5 \mathrm{~V}$. Note in these figures the nitrite $\left(\mathrm{NO}_{2}{ }^{-}\right)$levels correspond with the left axis and are in parts per thousand (ppt), i.e. $5700 \mathrm{ppm}=5.7 \mathrm{ppt}$. The important finding is that by the end of the SRAT cycle (after the reflux phase) only Run $2 \mathrm{~V}$ still had nitrite, about $254 \mathrm{ppm}$. This result led to the increasing of acid stoichiometry in Run $1 \mathrm{~V}$ and $4 \mathrm{~V}$ to insure nitrite destruction. From this data it appears $170 \%$ stoichiometry is sufficient for nitrite destruction by the end of the SRAT cycle but $155 \%$ is not.

\footnotetext{
${ }^{6}$ Reflux times included SRAT dewatering time and were longer than normal due to the wait for evidence of nitrite destruction or a peak in the hydrogen generation.
} 
Table VI. Nitrite Destruction for Large CPC Batch

\begin{tabular}{|c|c|c|c|c|}
\hline Run & Stoichiometry & $\begin{array}{c}\text { SRAT Pre-Nitric } \\
\mathrm{NO}_{2}^{-}\end{array}$ & $\begin{array}{c}\text { SRAT-Pre Reflux } \\
\mathrm{NO}_{2}^{-}\end{array}$ & $\begin{array}{c}\text { SRAT-Post Reflux } \\
\mathrm{NO}_{2}^{-}\end{array}$ \\
\hline IV & $197 \%$ & $5748 \mathrm{ppm}$ & $0 \mathrm{ppm}$ & $0 \mathrm{ppm}$ \\
\hline 2V & $155 \%$ & $5487 \mathrm{ppm}$ & $1646 \mathrm{ppm}$ & $254 \mathrm{ppm}$ \\
\hline 3V & $340 \%$ & $6006 \mathrm{ppm}$ & $0 \mathrm{ppm}$ & $0 \mathrm{ppm}$ \\
\hline 4V & $175 \%$ & $6630 \mathrm{ppm}$ & $144 \mathrm{ppm}$ & $0 \mathrm{ppm}$ \\
\hline 5V & $170 \%$ & $5532 \mathrm{ppm}$ & $91 \mathrm{ppm}$ & $0 \mathrm{ppm}$ \\
\hline
\end{tabular}

\section{F-N Calculation for SME Product}

For all runs, the amount of acid used was based on the Total Acid Target and a $\mathrm{Fe}^{+2} / \mathrm{Fe}_{\text {total }}$ REDOX target of 0.22 . Although the adjusted REDOX flowsheet was used, REDOX was not measured (only predicted) since glass quality was not the target of this investigation. However, since formate and nitrate measurements of the SME product were completed, [F-N] values for the four runs are shown in Table VII assuming a SME product with $45 \mathrm{wt} \%$ total solids for comparison with earlier data.

Table VII. SME Product [F-N] Values for Large CPC Batch

\begin{tabular}{|l|c|l|}
\hline Run & Stoichiometry & SME [F-N] \\
\hline $1 \mathrm{~V}$ & $197 \%$ & $0.471 \mathrm{~mol} / \mathrm{L}$ \\
\hline $2 \mathrm{~V}$ & $155 \%$ & $0.500 \mathrm{~mol} / \mathrm{L}$ \\
\hline $3 \mathrm{~V}$ & $340 \%$ & $0.929 \mathrm{~mol} / \mathrm{L}$ \\
\hline $4 \mathrm{~V}$ & $175 \%$ & $0.413 \mathrm{~mol} / \mathrm{L}$ \\
\hline $5 \mathrm{~V}$ & $170 \%$ & $0.456 \mathrm{~mol} / \mathrm{L}$ \\
\hline
\end{tabular}

\section{Product Compositions}

The Mobile Lab and ADS analyzed both the SRAT and SME products for total solids, elemental solids, and densities. The predicted and measured weight percent solids and densities for the SRAT product are shown in Table VIII. The measured and predicted analyses for the SME products are shown in Table IX. The predicted and measured values compare quite well considering the variance in the measurement and sampling. Too much water was removed in SME Runs $2 \mathrm{~V}$ and $3 \mathrm{~V}$ because the initial concentration to 6000 gallons was not factored in properly. This extra water removal caused the higher than normal total weight percent solids (52-56 wt\%). 
Westinghouse Savannah River Company

Savannah River Technology Center
WSRC-TR-99-00111, Rev. 0

Page 16 of 111

Table VIII. Total and Elemental Weight Percent Solids for SRAT Product

\begin{tabular}{|c|c|c|c|c|c|c|c|c|c|c|}
\hline Run & \multicolumn{2}{|c|}{ IV } & \multicolumn{2}{|c|}{$2 \mathrm{~V}$} & \multicolumn{2}{|c|}{ 3V } & \multicolumn{2}{|c|}{$4 V$} & \multicolumn{2}{|c|}{$5 \mathrm{~V}$} \\
\hline & Predicted & Measured & Predicted & Measured & Predicted & Measured & Predicted & Measured & Predicted & Measured \\
\hline $\begin{array}{l}\text { Total } \\
\text { Wt\% } \\
\text { Solids }\end{array}$ & - & $33.23 \%$ & -- & $31.06 \%$ & -- & $36.17 \%$ & -- & $32.17 \%$ & -- & $29.32 \%$ \\
\hline $\begin{array}{c}\text { Density } \\
(\mathrm{g} / \mathrm{ml})\end{array}$ & - & 1.21 & - & 1.17 & - & 1.18 & -- & 1.21 & -- & 1.13 \\
\hline Species & $\begin{array}{l}\text { wt\% } \\
\text { Dried } \\
\text { Solids } \\
\end{array}$ & $\begin{array}{l}\text { wt\% Dried } \\
\text { Solids }\end{array}$ & $\begin{array}{c}\text { wt\% } \\
\text { Dried } \\
\text { Solids }\end{array}$ & $\begin{array}{c}\text { wt\% Dried } \\
\text { Solids }\end{array}$ & $\begin{array}{l}\text { wt\% Dried } \\
\text { Solids }\end{array}$ & $\begin{array}{l}\text { wt\% Dried } \\
\text { Solids }\end{array}$ & $\begin{array}{c}\text { wt\% Dried } \\
\text { Solids }\end{array}$ & $\begin{array}{c}\text { wt\% Dried } \\
\text { Solids }\end{array}$ & $\begin{array}{l}\text { wt\% } \\
\text { Dried } \\
\text { Solids }\end{array}$ & $\begin{array}{l}\text { wt\% Dried } \\
\text { Solids }\end{array}$ \\
\hline $\mathrm{Al}$ & $5.59 \%$ & $5.51 \%$ & $5.56 \%$ & $5.51 \%$ & $5.57 \%$ & $4.89 \%$ & $5.60 \%$ & $5.38 \%$ & $5.57 \%$ & $7.18 \%$ \\
\hline $\mathbf{A g}$ & $0.04 \%$ & -- & $0.04 \%$ & $\overline{--}$ & $0.04 \%$ & -- & $0.04 \%$ & -- & $0.04 \%$ & -- \\
\hline $\mathrm{Ca}$ & $2.38 \%$ & $2.21 \%$ & $2.01 \%$ & $2.12 \%$ & $2.01 \%$ & $1.91 \%$ & $2.39 \%$ & $2.20 \%$ & $2.01 \%$ & $2.68 \%$ \\
\hline $\mathbf{C d}$ & $0.09 \%$ & $0.08 \%$ & $0.09 \%$ & $0.08 \%$ & $0.09 \%$ & $0.10 \%$ & $0.09 \%$ & $0.09 \%$ & $0.11 \%$ & $0.08 \%$ \\
\hline $\mathrm{Cl}$ & $0.03 \%$ & -- & $0.05 \%$ & -- & $0.05 \%$ & -- & $0.02 \%$ & -- & $0.03 \%$ & -- \\
\hline $\mathrm{Cr}$ & $0.15 \%$ & -- & $0.16 \%$ & -- & $0.16 \%$ & -- & $0.15 \%$ & -- & $0.16 \%$ & $0.11 \%$ \\
\hline $\mathrm{Cu}$ & $0.02 \%$ & $0.02 \%$ & $0.02 \%$ & $0.02 \%$ & $0.02 \%$ & $0.01 \%$ & $0.02 \%$ & $0.02 \%$ & $0.02 \%$ & $0.01 \%$ \\
\hline $\mathrm{F}$ & $0.01 \%$ & - & $0.01 \%$ & - & $0.01 \%$ & -- & $0.01 \%$ & - & $0.01 \%$ & \\
\hline $\mathrm{Fe}$ & $21.63 \%$ & $19.90 \%$ & $22.34 \%$ & $19.20 \%$ & $22.39 \%$ & $17.00 \%$ & $21.66 \%$ & $21.15 \%$ & $22.38 \%$ & $20.50 \%$ \\
\hline $\mathrm{Hg}$ & $1.13 \%$ & $0.37 \%$ & $1.13 \%$ & $0.36 \%$ & $1.15 \%$ & $0.08 \%$ & $1.16 \%$ & $0.10 \%$ & $1.15 \%$ & $0.26 \%$ \\
\hline $\mathrm{K}$ & $0.12 \%$ & $0.16 \%$ & $0.15 \%$ & $0.15 \%$ & $0.15 \%$ & $0.19 \%$ & $0.12 \%$ & $0.15 \%$ & $0.15 \%$ & $0.29 \%$ \\
\hline $\mathrm{Li}$ & $0.01 \%$ & $<0.01 \%$ & $0.00 \%$ & $<0.01 \%$ & $0.00 \%$ & $<0.01 \%$ & $0.01 \%$ & $<0.01 \%$ & $0.00 \%$ & $0.00 \%$ \\
\hline $\mathrm{Mg}$ & $1.04 \%$ & $1.05 \%$ & $1.07 \%$ & $0.98 \%$ & $1.08 \%$ & $0.84 \%$ & $1.04 \%$ & $1.03 \%$ & $1.08 \%$ & $1.06 \%$ \\
\hline $\mathrm{Mn}$ & $4.23 \%$ & $4.13 \%$ & $4.36 \%$ & $4.12 \%$ & $4.37 \%$ & $3.55 \%$ & $4.23 \%$ & $4.26 \%$ & $4.36 \%$ & $4.45 \%$ \\
\hline $\mathrm{Na}$ & $6.55 \%$ & $6.59 \%$ & $7.65 \%$ & $6.80 \%$ & $7.67 \%$ & $5.93 \%$ & $6.52 \%$ & $6.62 \%$ & $7.67 \%$ & $5.02 \%$ \\
\hline $\mathrm{Ni}$ & $0.40 \%$ & $0.37 \%$ & $0.34 \%$ & $0.31 \%$ & $0.34 \%$ & $0.27 \%$ & $0.40 \%$ & $0.38 \%$ & $0.34 \%$ & $0.33 \%$ \\
\hline$P$ & $0.25 \%$ & $0.28 \%$ & $0.04 \%$ & $0.26 \%$ & $0.04 \%$ & $0.27 \%$ & $0.25 \%$ & $0.28 \%$ & $0.04 \%$ & $0.19 \%$ \\
\hline $\mathbf{P d}$ & $0.01 \%$ & $<0.01 \%$ & $0.01 \%$ & $<0.01 \%$ & $0.01 \%$ & $<0.01 \%$ & $0.01 \%$ & $<0.01 \%$ & $0.00 \%$ & $0.00 \%$ \\
\hline $\mathbf{R h}$ & $0.01 \%$ & $<0.01 \%$ & $0.01 \%$ & $<0.01 \%$ & $0.01 \%$ & $<0.01 \%$ & $0.01 \%$ & $<0.01 \%$ & $0.01 \%$ & $0.01 \%$ \\
\hline $\mathbf{R u}$ & $0.02 \%$ & $0.04 \%$ & $0.02 \%$ & $0.04 \%$ & $0.02 \%$ & $0.03 \%$ & $0.02 \%$ & $0.04 \%$ & $0.02 \%$ & $0.02 \%$ \\
\hline $\mathrm{Si}$ & $1.14 \%$ & $0.08 \%$ & $1.53 \%$ & $0.07 \%$ & $1.54 \%$ & $0.07 \%$ & $1.13 \%$ & $0.06 \%$ & $1.54 \%$ & $1.40 \%$ \\
\hline $\mathrm{Te}$ & $0.00 \%$ & $<0.01 \%$ & $0.00 \%$ & $<0.01 \%$ & $0.00 \%$ & $<0.01 \%$ & $0.00 \%$ & $<0.01 \%$ & $0.00 \%$ & $0.00 \%$ \\
\hline $\mathrm{Ti}$ & $0.04 \%$ & $0.04 \%$ & $0.04 \%$ & $0.04 \%$ & $0.05 \%$ & $0.04 \%$ & $0.04 \%$ & $0.04 \%$ & $0.05 \%$ & $0.03 \%$ \\
\hline $\mathrm{Zn}$ & $0.12 \%$ & $0.12 \%$ & $0.03 \%$ & $0.11 \%$ & $0.03 \%$ & $0.10 \%$ & $0.12 \%$ & $0.12 \%$ & $0.03 \%$ & $0.12 \%$ \\
\hline
\end{tabular}


Westinghouse Savannah River Company

Savannah River Technology Center
WSRC-TR-99-00111, Rev. 0

Page 17 of 111

Table IX. Total and Elemental Weight Percent Solids for SME Product

\begin{tabular}{|c|c|c|c|c|c|c|c|c|c|c|}
\hline Run & \multicolumn{2}{|c|}{ IV } & \multicolumn{2}{|c|}{$2 \mathrm{~V}$} & \multicolumn{2}{|c|}{$3 \mathbf{V}$} & \multicolumn{2}{|c|}{$4 V$} & \multicolumn{2}{|c|}{$5 \mathrm{~V}$} \\
\hline & Predicted & Measured & Predicted & Measured & Predicted & Measured & Predicted & Measured & Predicted & Meaśured \\
\hline $\begin{array}{l}\text { Total } \\
\text { Wt\% } \\
\text { Solids }\end{array}$ & -- & $47.09 \%$ & -- & $52.51 \%$ & -- & $56.32 \%$ & - & $48.06 \%$ & -- & $45.59 \%$ \\
\hline $\begin{array}{l}\text { Density } \\
(\mathrm{g} / \mathrm{ml}) \\
\end{array}$ & - & 1.25 & -- & 1.30 & -- & 1.47 & -- & 1.31 & -- & 1.34 \\
\hline Species & $\begin{array}{c}\text { wt\% } \\
\text { Dried } \\
\text { Solids }\end{array}$ & $\begin{array}{c}\text { wt\% Dried } \\
\text { Solids }\end{array}$ & $\begin{array}{c}\text { wt\% } \\
\text { Dried } \\
\text { Solids }\end{array}$ & $\begin{array}{l}\text { wt\% Dried } \\
\text { Solids }\end{array}$ & $\begin{array}{c}\text { wt\% Dried } \\
\text { Solids }\end{array}$ & $\begin{array}{l}\text { wt\% Dried } \\
\text { Solids }\end{array}$ & $\begin{array}{l}\text { wt } \% \text { Dried } \\
\text { Solids }\end{array}$ & $\begin{array}{c}\text { wt\% Dried } \\
\text { Solids }\end{array}$ & $\begin{array}{c}\text { wt\% } \\
\text { Dried } \\
\text { Solids }\end{array}$ & $\begin{array}{l}\text { wt\% Dried } \\
\text { Solids }\end{array}$ \\
\hline $\mathrm{Al}$ & $1.79 \%$ & $1.73 \%$ & $1.75 \%$ & $1.89 \%$ & $1.53 \%$ & $1.71 \%$ & $1.75 \%$ & $1.87 \%$ & $2.30 \%$ & $2.40 \%$ \\
\hline $\mathbf{A g}$ & $0.01 \%$ & -- & $0.01 \%$ & -- & $0.01 \%$ & -- & $0.01 \%$ & -- & $0.00 \%$ & -- \\
\hline $\mathrm{B}$ & $2.77 \%$ & -- & $2.81 \%$ & -- & $2.78 \%$ & -- & $2.77 \%$ & & $2.76 \%$ & $2.43 \%$ \\
\hline $\mathrm{Ca}$ & $0.72 \%$ & $0.76 \%$ & $0.67 \%$ & $0.81 \%$ & $0.60 \%$ & $0.75 \%$ & $0.71 \%$ & $0.73 \%$ & $0.89 \%$ & $0.99 \%$ \\
\hline $\mathbf{C d}$ & $0.03 \%$ & $0.03 \%$ & $0.03 \%$ & $0.03 \%$ & $0.03 \%$ & $0.04 \%$ & $0.03 \%$ & $0.03 \%$ & $0.03 \%$ & $0.01 \%$ \\
\hline $\mathrm{Cl}$ & $0.00 \%$ & -- & $0.00 \%$ & -- & $0.00 \%$ & -- & $0.00 \%$ & -- & $0.00 \%$ & -- \\
\hline $\mathrm{Cr}$ & $0.05 \%$ & -- & $0.01 \%$ & -- & $0.05 \%$ & -- & $0.05 \%$ & -- & $0.00 \%$ & $0.03 \%$ \\
\hline $\mathrm{Cu}$ & $0.01 \%$ & $<0.01 \%$ & $0.01 \%$ & $<0.01 \%$ & $0.00 \%$ & $0.01 \%$ & $0.01 \%$ & $<0.01 \%$ & $0.00 \%$ & $0.00 \%$ \\
\hline $\mathrm{F}$ & $0.00 \%$ & - & $0.00 \%$ & - & $0.00 \%$ & -- & $0.00 \%$ & -- & $0.00 \%$ & - \\
\hline $\mathrm{Fe}$ & $6.46 \%$ & $6.30 \%$ & $6.11 \%$ & $6.85 \%$ & $5.33 \%$ & $6.37 \%$ & $6.87 \%$ & $6.95 \%$ & $6.50 \%$ & $6.60 \%$ \\
\hline $\mathrm{Hg}$ & $0.12 \%$ & $0.03 \%$ & $0.12 \%$ & $0.02 \%$ & $0.03 \%$ & $0.02 \%$ & $0.03 \%$ & $0.02 \%$ & $0.04 \%$ & $0.04 \%$ \\
\hline $\mathrm{K}$ & $0.05 \%$ & $<0.15 \%$ & $0.05 \%$ & $<0.15 \%$ & $0.06 \%$ & $0.11 \%$ & $0.05 \%$ & $<0.15 \%$ & $0.10 \%$ & $0.16 \%$ \\
\hline $\mathrm{Li}$ & $1.72 \%$ & $1.27 \%$ & $1.72 \%$ & $1.43 \%$ & $1.72 \%$ & $1.43 \%$ & $1.72 \%$ & $1.31 \%$ & $1.72 \%$ & $0.00 \%$ \\
\hline $\mathrm{Mg}$ & $1.24 \%$ & $0.99 \%$ & $1.21 \%$ & $1.07 \%$ & $1.16 \%$ & $1.08 \%$ & $1.23 \%$ & $1.03 \%$ & $1.24 \%$ & $1.11 \%$ \\
\hline $\mathrm{Mn}$ & $1.34 \%$ & $1.30 \%$ & $1.31 \%$ & $1.37 \%$ & $1.11 \%$ & $1.31 \%$ & $1.38 \%$ & $1.36 \%$ & $1.46 \%$ & $1.43 \%$ \\
\hline $\mathrm{Na}$ & $8.18 \%$ & $6.62 \%$ & $8.20 \%$ & $7.24 \%$ & $7.90 \%$ & $7.41 \%$ & $8.19 \%$ & $6.94 \%$ & $7.63 \%$ & $5.17 \%$ \\
\hline $\mathrm{Ni}$ & $0.12 \%$ & $0.12 \%$ & $0.10 \%$ & $0.10 \%$ & $0.08 \%$ & $0.10 \%$ & $0.12 \%$ & $0.13 \%$ & $0.10 \%$ & $0.18 \%$ \\
\hline P & $0.09 \%$ & $0.07 \%$ & $0.08 \%$ & $0.07 \%$ & $0.08 \%$ & $0.11 \%$ & $0.09 \%$ & $0.08 \%$ & $0.06 \%$ & $0.08 \%$ \\
\hline Pd & $0.00 \%$ & $<0.10 \%$ & $0.00 \%$ & $<0.10 \%$ & $0.00 \%$ & $<0.10 \%$ & $0.00 \%$ & $<0.10 \%$ & $.0 .00 \%$ & $0.00 \%$ \\
\hline $\mathbf{R h}$ & $0.00 \%$ & $<0.10 \%$ & $0.00 \%$ & $<0.10 \%$ & $0.00 \%$ & $<0.10 \%$ & $0.00 \%$ & $<0.10 \%$ & $0.00 \%$ & $0.00 \%$ \\
\hline $\mathbf{R u}$ & $0.01 \%$ & $0.02 \%$ & $0.01 \%$ & $0.01 \%$ & $0.01 \%$ & $0.02 \%$ & $0.01 \%$ & $0.01 \%$ & $0.01 \%$ & $0.00 \%$ \\
\hline $\mathrm{Si}$ & $24.24 \%$ & $20.7 \%$ & $24.24 \%$ & $22.3 \%$ & $24.24 \%$ & $21.3 \%$ & $24.24 \%$ & $21.7 \%$ & $24.67 \%$ & $23.00 \%$ \\
\hline $\mathrm{Te}$ & $0.00 \%$ & $<0.01 \%$ & $0.00 \%$ & $<0.01 \%$ & $0.00 \%$ & $<0.01 \%$ & $0.00 \%$ & $<0.01 \%$ & $0.00 \%$ & $0.00 \%$ \\
\hline $\mathrm{Ti}$ & $0.01 \%$ & $0.03 \%$ & $0.01 \%$ & $0.03 \%$ & $0.01 \%$ & $0.02 \%$ & $0.01 \%$ & $0.03 \%$ & $0.01 \%$ & $0.01 \%$ \\
\hline $\mathrm{Zn}$ & $0.04 \%$ & $0.03 \%$ & $0.04 \%$ & $0.04 \%$ & $0.03 \%$ & $0.04 \%$ & $0.04 \%$ & $0.04 \%$ & $0.04 \%$ & $0.03 \%$ \\
\hline
\end{tabular}


Westinghouse Savannah River Company

Savannah River Technology Center
WSRC-TR-99-00111, Rev. 0

Page 18 of 111

\section{Processing Problems}

\section{Mixing and Sampling}

One problem encountered during all runs was keeping the slurry well-mixed especially during the nitric acid addition of the SRAT cycles. The sludge slurry for the large batches was thicker than a normal batch due to the higher weight percent solids sludge used, the presence of a SRAT heel, and the boiling or concentration of a caustic sludge. Caustic sludge is thicker due to the hydroxyl interactions between particles in the sludge. These interactions cause the sludge to become sticky and gelatinous. The sludge slurry was at its thickest (by appearance) after the first dewatering to make room for the additional 1000 gallons of-sludge. In Run $2 \mathrm{~V}$ where the equivalent of 133 gallons of concentrated nitric acid was added before the first dewatering, the slurry was as thick as the other. runs based upon visual observations. Thus the pre-boiling acid may not be beneficial in terms of alleviating boiling a caustic sludge. However, for all runs the process was able to continue by increasing the mixer speed at various times. Table $X$ gives a summary of the initial, maximum, and final mixer speeds for each run. For all runs, once the acid had been added in the SRAT cycle, the slurry was much less viscous and mixing was not a problem.

Table X. Mixer Speeds for Large Batch Runs

\begin{tabular}{|l|l|l|l|l|}
\hline Run & $\begin{array}{l}\text { Initial Speed } \\
(\mathrm{RPM})\end{array}$ & $\begin{array}{l}\text { Maximum Speed } \\
(\mathrm{RPM})\end{array}$ & $\begin{array}{l}\text { Maximum Speed } \\
\text { Location }\end{array}$ & $\begin{array}{l}\text { Final Speed } \\
\text { (RPM) }\end{array}$ \\
\hline $1 \mathrm{~V}$ & 200 & 300 & $\begin{array}{l}\text { Before Nitric } \\
\text { Addition }\end{array}$ & 240 \\
\hline $2 \mathrm{~V}$ & 200 & 250 & $\begin{array}{l}\text { Start of Formic } \\
\text { Addition }\end{array}$ & 200 \\
\hline $3 \mathrm{~V}$ & 200 & 260 & $\begin{array}{l}\text { End of Nitric } \\
\text { Addition }\end{array}$ & 210 \\
\hline $4 \mathrm{~V}$ & 200 & 300 & $\begin{array}{l}\text { Before Nitric } \\
\text { Addition }\end{array}$ & 200 \\
\hline $5 \mathrm{~V}$ & 200 & 250 & $\begin{array}{l}\text { Start of Nitric } \\
\text { Addition }\end{array}$ & 200 \\
\hline
\end{tabular}

Related to the mixing problem, pulling samples was difficult during the SRAT cycles due to the thickness of the slurry. This problem did not prevent the collection of samples, but it took longer to pull them.

\section{$\underline{\text { Rheology }}$}

In order to understand the mixing and sampling problems encountered in the SRAT cycles, samples were pulled at the completion of the SRAT cycle for rheology analysis. Two samples, SRAT IV and $3 \mathrm{~V}$ products, were analyzed by a $T A$ Instruments rheometer being demonstrated at TNX. The resulting shear stresses versus shear rate curves are shown in Figure 6. Note that Batch $3 \mathrm{~V}$ with the excessive acid addition ( $340 \%$ stoichiometry) had a much lower yield stress of 31 dynes $/ \mathrm{cm}^{2}$ compared to Batch $1 \mathrm{~V}$ with a yield stress of 287 dynes $/ \mathrm{cm}^{2}$ and less added acid $(197 \%$ stoichiometry). Also Batch 3V's apparent viscosity of $14.3 \mathrm{cP}$ was lower than Batch 1V's viscosity of 
$48.7 \mathrm{cP}$. This data confirms observations that the SRAT 3V product (high acid addition) was much thinner (i.e. lower shear stress) than the SRAT $1 \mathrm{~V}$ product (nominal acid addition). The $\boldsymbol{T A}$ Instruments rheometer only needs a 3-ml sample to perform the shear stress measurements. Samples for all Runs $1 \mathrm{~V}$ through $5 \mathrm{~V}$ were analyzed later by a Haake rheometer. The shear stresses versus shear rate curves are shown in Figure 7. The yield stresses and apparent viscosities for all runs are shown in Table XI. The TA Instruments and Haake results agree well considering the different samples and techniques used. The shapes of the curves are very similar too. The Haake results confirm the TA Instruments findings, the high acid slurry (3V) was much thinner than all the other runs. Also, Run $4 \mathrm{~V}$ and $5 \mathrm{~V}$ were very similar from a rheological point of view as expected. Note the shear stress trajectories become more curved as the acid addition goes up but flattens out by the time $340 \%$ is reached.

To compare the thickness of the SRAT product of the increased CPC batch with a normal size batch, a Tank 42 sludge-only SRAT product (Tank 42 SRAT) from earlier experiments ${ }^{7}$ and the large batch SRAT heel for Runs 1V through 4V (SRAT Heel) described in Appendix A-1 were also analyzed. The Tank 42 sludge-only SRAT product was from a 25 -wt $\%$ total solids sludge with $125 \%$ acid and the SRAT heel was a 20 -wt\% total solids sludge with $141 \%$ acid. The shear stress versus shear rate curves for these normal-sized batches are shown in Figure 8. The yield stresses and apparent viscosities for the normal-sized batches SRAT Heel and Tank 42 SRAT are included in Table XI. Note that the thinnest large batch SRAT product from Run $3 \mathrm{~V}$ has a higher yield stress and apparent viscosity than either normal sized batch. These limited results support the observations about mixing and sampling, i.e. the mixing speeds were increased above normal, and sampling was more difficult than normal due to the thicker, more viscous slurry. The SRAT Heel yield stress and viscosity seem unnecessarily low and may be due to a poor sample. More rheological data needs to be collected to better characterize the normal versus large batch SRAT product. More data is especially needed after the first dewater step of the SRAT cycle when the slurry appears to be its thickest.

Table XI. Yield Stress and Apparent Viscosity for ȘRAT Products

\begin{tabular}{|c|c|c|c|c|}
\hline Run & Acid Stoichiometry & Yield Stress & Apparent Viscosity & Total Wt\% Solids \\
\hline & & Dynes/cm & centipoise (cP) & \\
\hline 1V & $197 \%$ & 179 & 36.5 & $33 \%$ \\
\hline 2V & $155 \%$ & 113.5 & 26.6 & $31 \%$ \\
\hline 3V & $340 \%$ & 34.8 & 16.7 & $36 \%$ \\
\hline 4V & $175 \%$ & 142 & 38 & $32 \%$ \\
\hline 5V & $170 \%$ & 140.5 & 41 & $29 \%$ \\
\hline SRAT Heel & $141 \%$ & 1.1 & 2.2 & $20 \%$ \\
\hline Tank 42 SRAT & $125 \%$ & 24 & 11 & $25 \%$ \\
\hline
\end{tabular}

${ }^{7}$ D. P. Lambert, P. R. Monson, Hydrogen Generation Rate During Melter Feed Preparation of Tank 42 Sludge and CST in the Defense Waste Processing Facility (DWPF) (U), WSRC-TR-98-00297, Rev. 0, September 21, 1998. 


\section{TA Instruments}

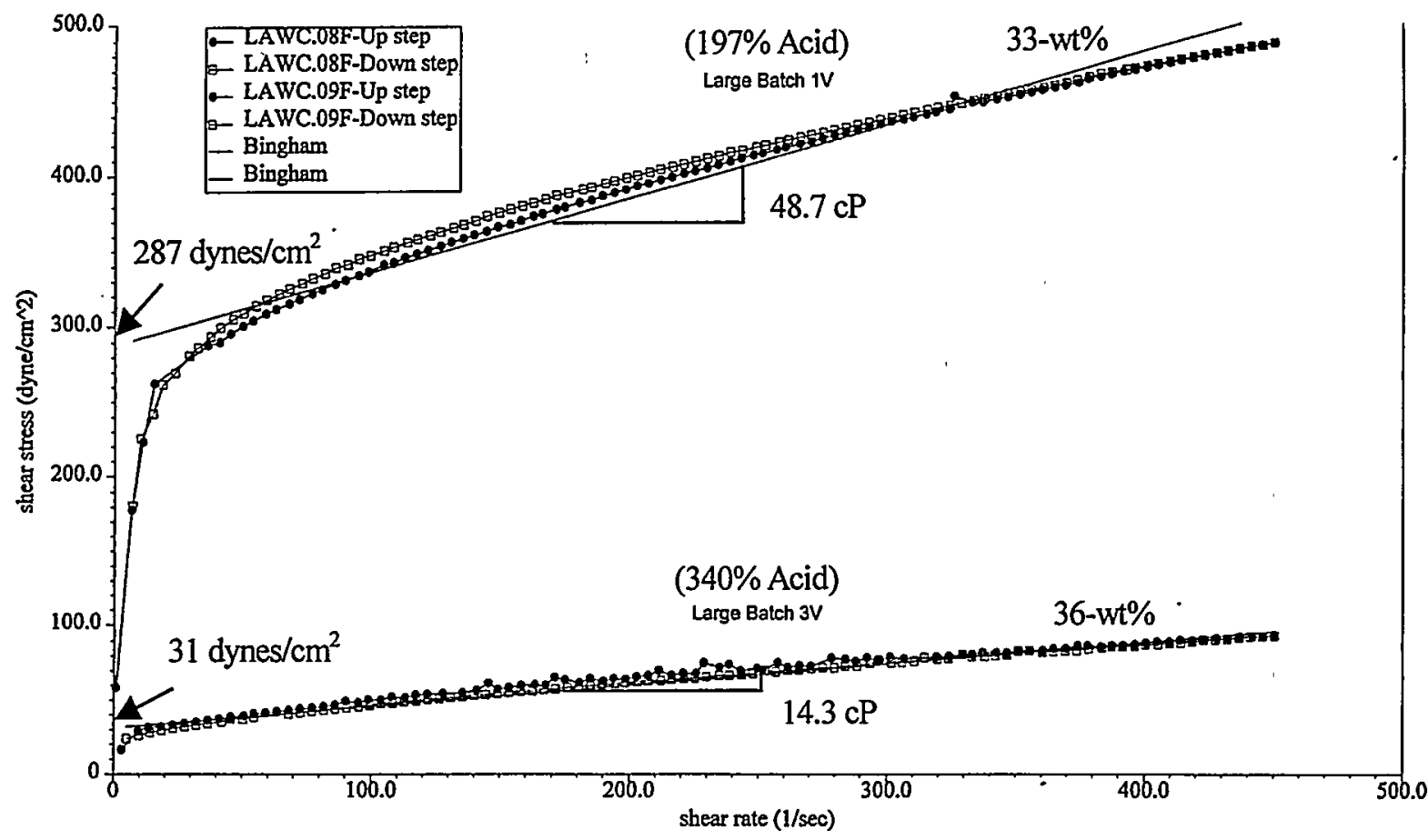

Figure 6. Shear Stress versus Rate for SRAT 1V and 3V Products on TA Instruments

\section{Haake}

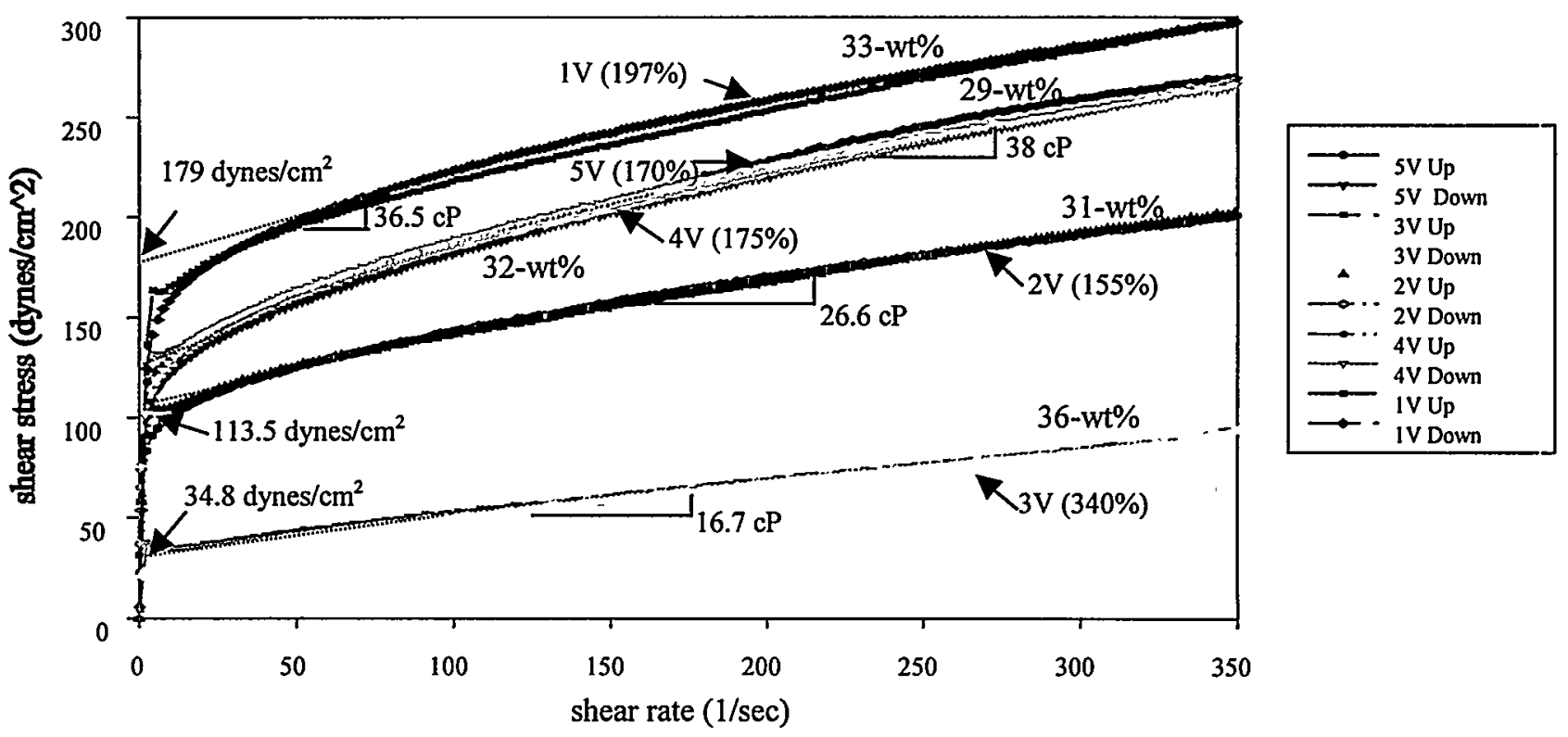

Figure 7. Shear Stress versus Rate for SRAT Products on Haake Rheometer 


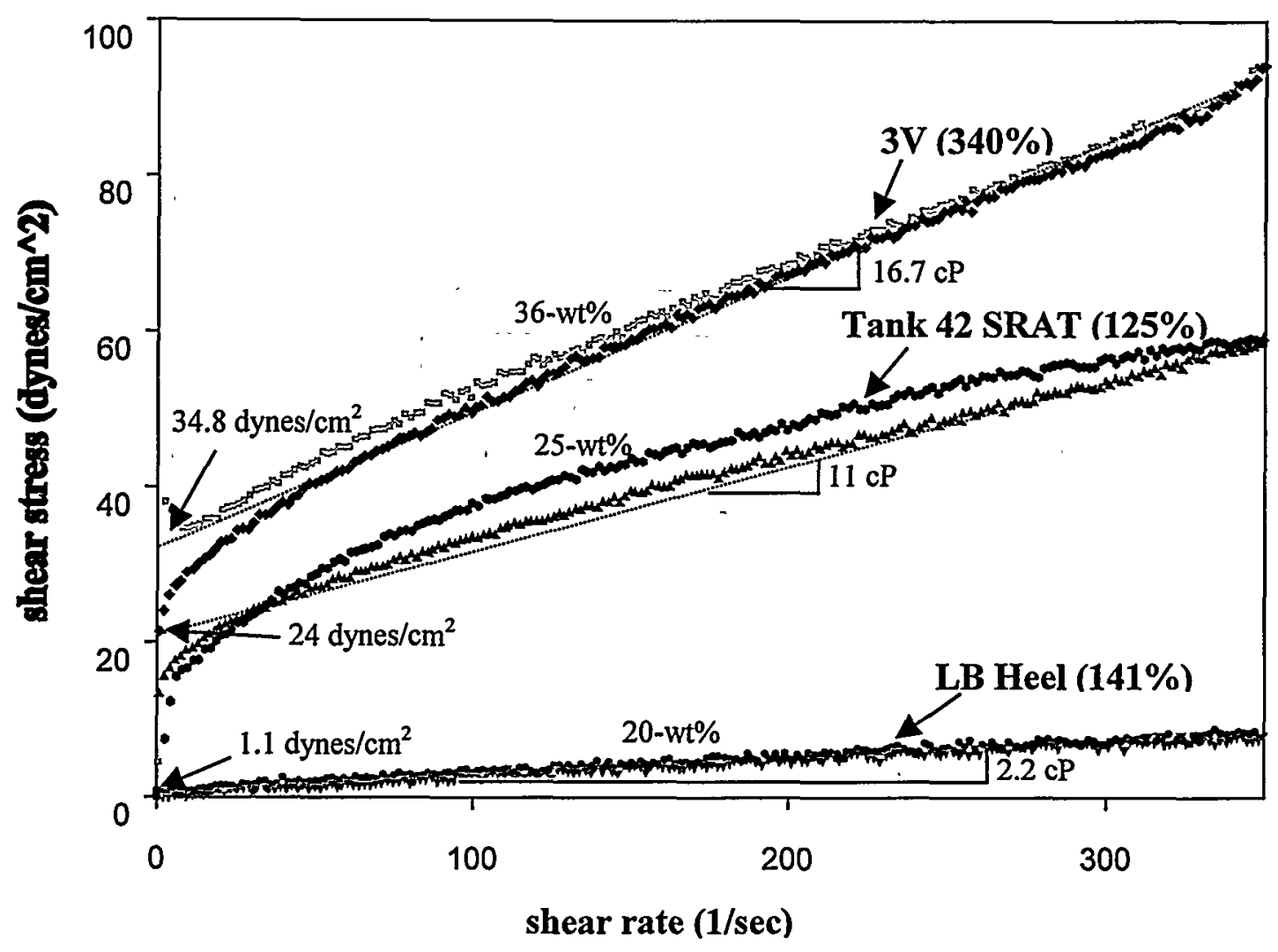

\begin{tabular}{ll|}
\hline & Large Batch Heel - \\
$:$ & Large Batch Heel - \\
- & Large Batch 3V \\
- Sludge Batch 3V & Sludge-only Tank 42 SRAT Product \\
& Slunk 42 SRAT Product \\
\hline
\end{tabular}

Figure 8. Large Batch 3V versus Normal Batch Tank 42 \& LB Heel SRAT Rheology

\section{Fouling}

The cooling coil remained in the SRAT/SME vessel during the entire experiment. Water was only run through the coil when the vessel was cooled. There was no significant coil fouling as indicated in Table XII. The amount of fouling or accumulation was determined by subtracting the cooling dip leg's and stirrer's final weights from their initial weights and multiplying by the weight percent solids at the end of each run. The percentages represent the amount of solids left on the cooling coil and stirrer out of all the solids material added to the kettle. The fouling on the stirrer was reported to help verify the cooling dip leg's numbers. The stirrer's fouling numbers may be artificially inflated as the surface area and shape of its blades could cause more material to settle than on the cooling coil. Although counterintuitive, there appears to be more fouling as the acid stoichiometry or the amount of acid increases. This could be interpreted as more particles are dissolved or free to move about and stick to the cooling dip leg, stirrer, etc. as the acid increases. However, the percentage of fouling should not be a problem. For a better understanding of the cooling coil fouling, please refer to the 
pictures in Figure 9 through Figure 12. Note Figure 10 and Figure 11 were taken with an older digital camera with lower resolution and so had to be pieced together from several photos. The other images were taken with a newer digital camera requiring only one picture.

Table XII. Coil Fouling for Large CPC Batch

\begin{tabular}{|c|c|c|c|c|c|c|}
\hline Run & Acid Stoichiometry & $\begin{array}{c}\text { Coil Fouling } \\
\text { Solids }\end{array}$ & $\begin{array}{c}\text { Coil Fouling } \\
\% \text { Solids }\end{array}$ & $\begin{array}{c}\text { Stirrer Fouling } \\
\text { Solids }\end{array}$ & $\begin{array}{c}\text { Stirrer Fouling } \\
\% \text { Solids }\end{array}$ & $\begin{array}{c}\text { Total } \\
\text { Solids }\end{array}$ \\
\hline 2V & $155 \%$ & $0.03 \mathrm{~g}$ & $0.00 \%$ & $2.04 \mathrm{~g}$ & $0.13 \%$ & 1579.5 \\
\hline 4V & $175 \%$ & $0.38 \mathrm{~g}$ & $0.02 \%$ & $3.12 \mathrm{~g}$ & $0.20 \%$ & 1556.9 \\
\hline 5V & $170 \%$ & $0.87 \mathrm{~g}$ & $0.06 \%$ & $3.60 \mathrm{~g}$ & $0.24 \%$ & 1486.9 \\
\hline 1V & $197 \%$ & $0.48 \mathrm{~g}$ & $0.03 \%$ & $3.85 \mathrm{~g}$ & $0.24 \%$ & 1584.8 \\
\hline 3V & $340 \%$ & $1.63 \mathrm{~g}$ & $0.11 \%$ & $6.70 \mathrm{~g}$ & $0.45 \%$ & 1495.1 \\
\hline
\end{tabular}
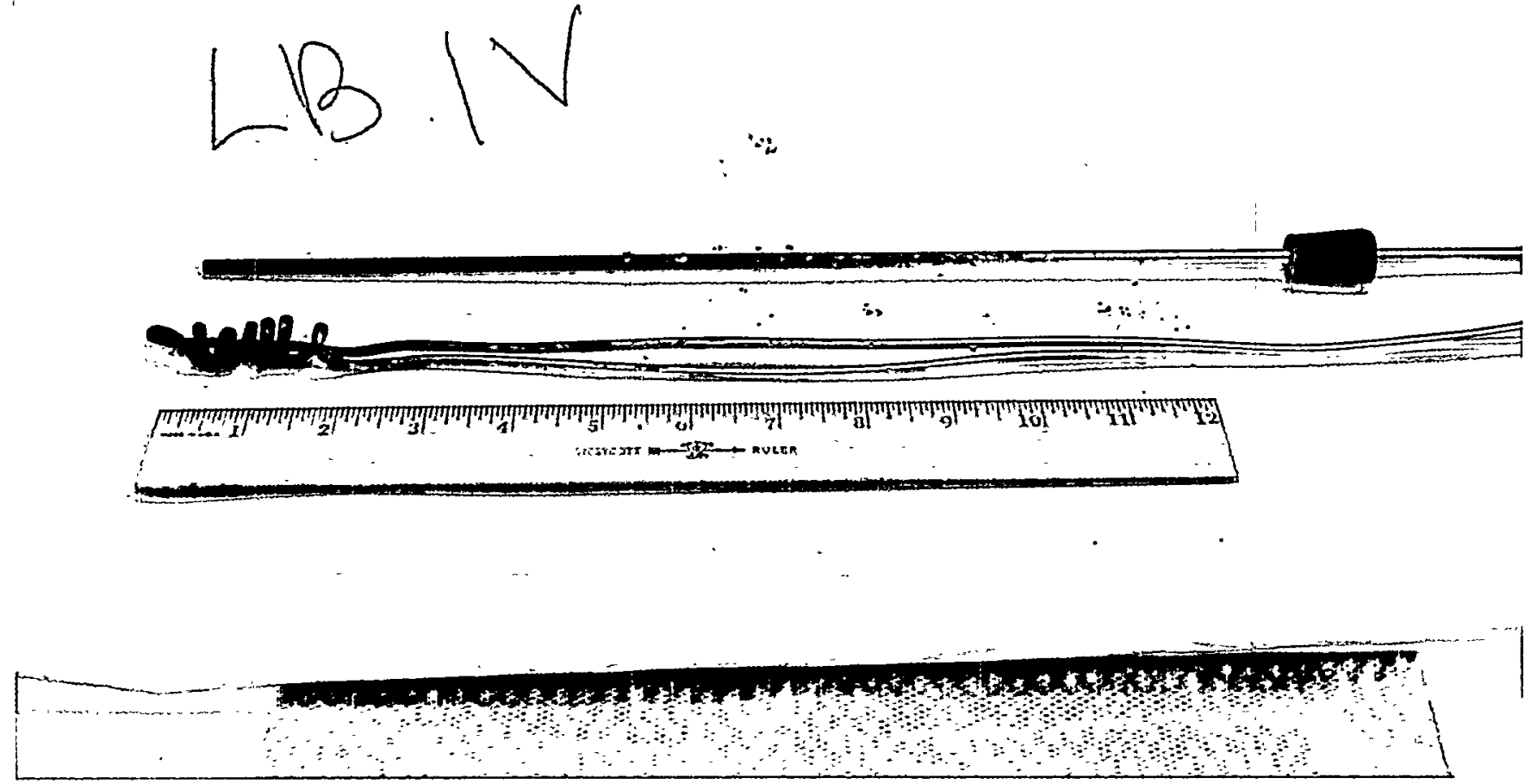

Figure 9. Cooling Dip Leg and Thermocouple for Large CPC Batch Run 1V.

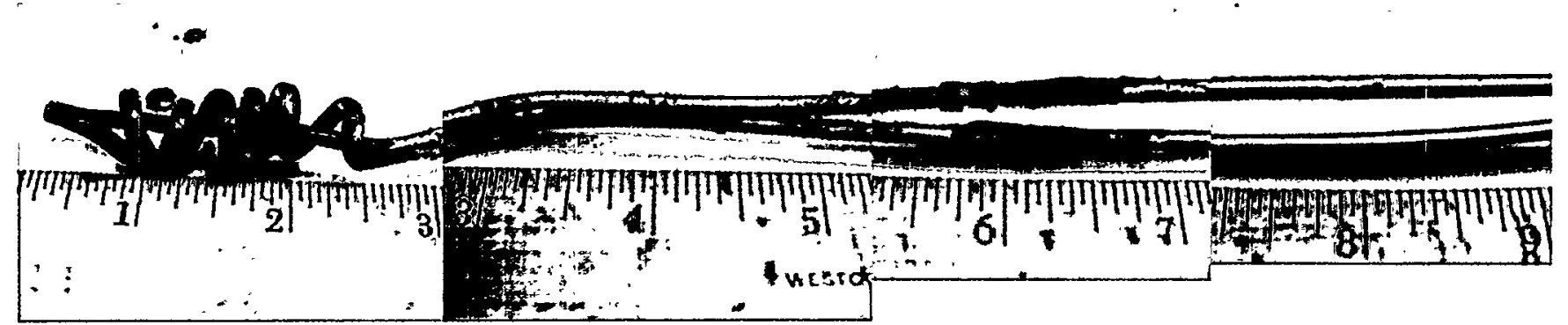

Figure 10. Cooling Dip Leg for Large CPC Batch Run 2V. 


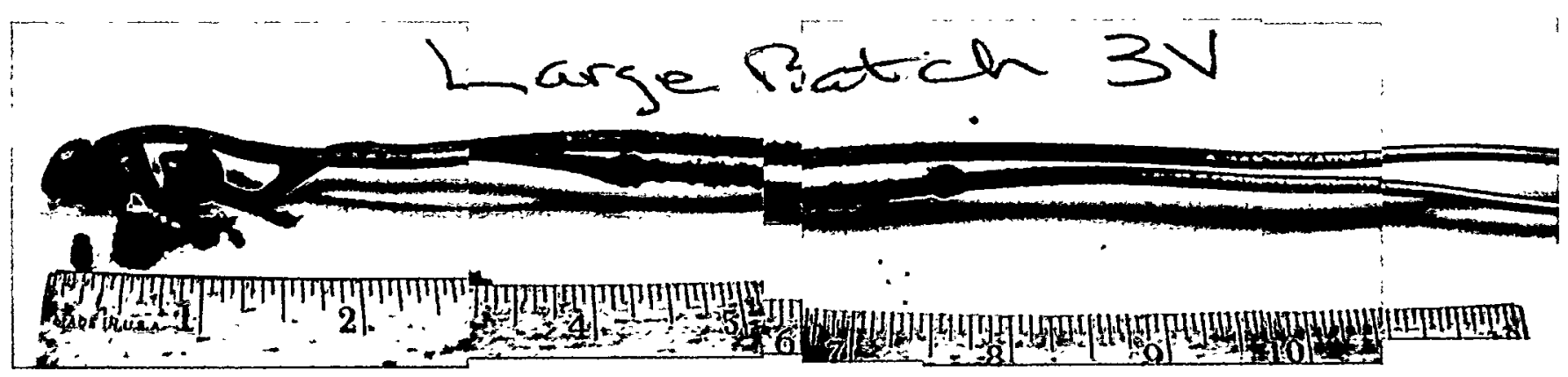

Figure 11. Cooling Dip Leg for Large CPC Batch Run 3V.

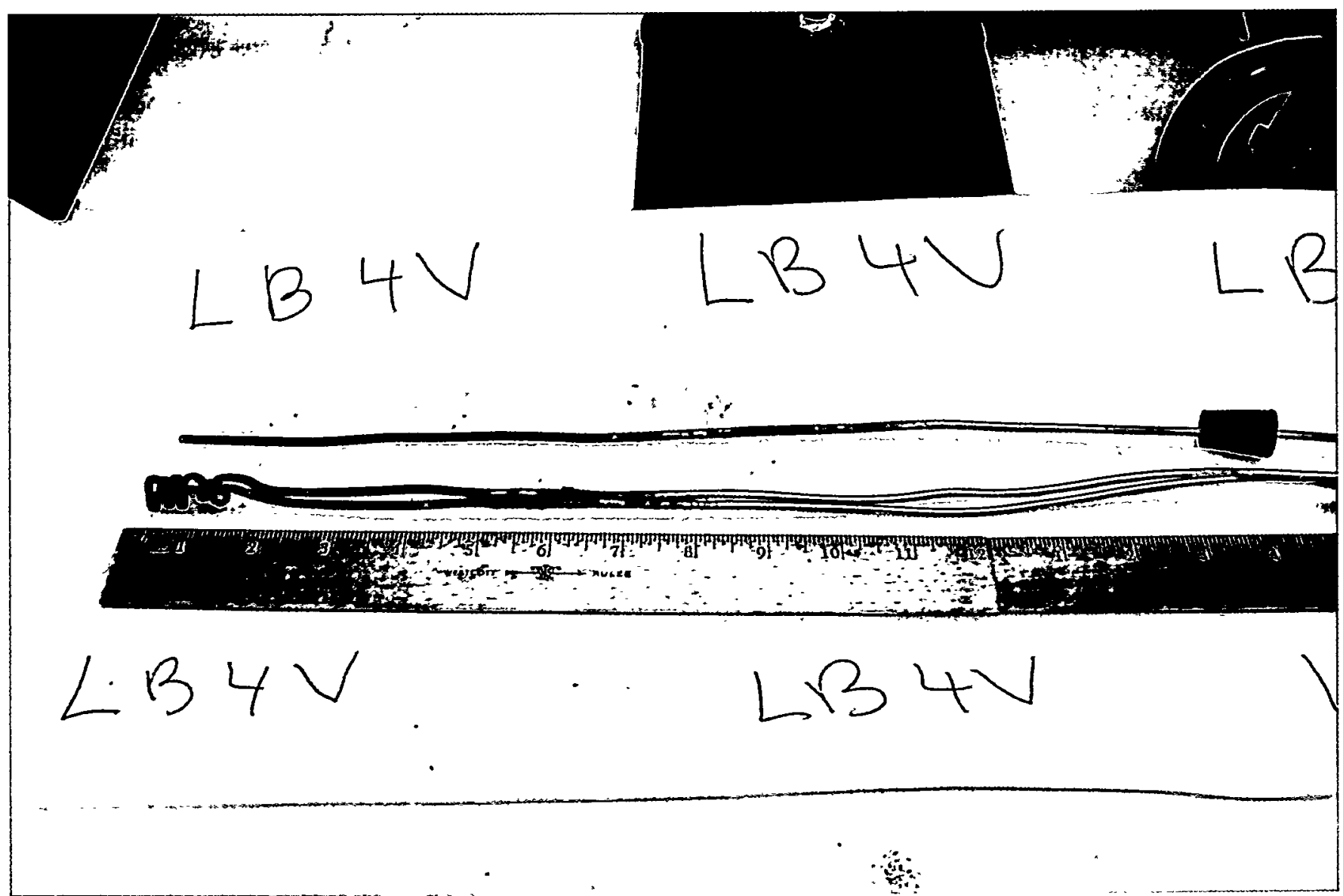

Figure 12. Cooling Dip Leg and RTD for Large CPC Batch Run 3V. 


\section{CONCLUSIONS}

These experiments demonstrated the feasibility of increasing the DWPF CPC batch size by adding more sludge to each batch and concentrating the sludge down to allow space for the addition of another 1000 gallons. After re-concentration, the CPC batch contains a greater waste solids loading for the same volume as a normal size batch. This increased waste loading should allow about one more canister to be poured per melter feed batch preparation.

From this limited set of runs, it appears DWPF could increase CPC batch size provided:

- More acid is used (somewhere between $155 \%$ and $170 \%$ )

- Slurry is kept well mixed at all times

- Heat Transfer coefficients do not fall to an unacceptable level

It should be noted that the sludge slurry is thicker than normal (especially during the beginning of the SRAT cycle) and DWPF mixing systems must be capable of mixing the higher solids slurry.

The processing problems observed during the increased CPC batch (extra 1000 gallons of sludge) bench scale experiments are summarized below:

- Exceeded hydrogen limit for large acid addition (340\% stoichiometry). Lower acid additions like $155 \%$ to $175 \%$ should not present a problem.

- Difficulty destroying Nitrite: Increased acid stoichiometry from $155 \%$ to $175 \%$ to compensate.

- Difficulty keeping slurry well-mixed especially before nitric acid addition was complete: Increased mixing speed to compensate.

- Difficulty pulling samples during SRAT cycle: After samples were pulled, the sampler tube was cleared by blowing its contents back in to the kettle.

None of these problems are insurmountable. However, more experiments will be needed to answer questions raised by this work.

\section{FUTURE WORK}

Although by increasing the acid addition, the nitrite destruction can be met for the increased CPC batch process, this in turn may cause problems with equipment erosion and hydrogen generation. An optimum operating point needs to be found where the reaction kinetics are satisfied yet constraints on glass properties such as REDOX and limitations of physical equipment such as agitation are considered. To help answer these and other questions, it is recommended that another set of benchscale runs be completed that look at the following items:

1. Acid targets between $150 \%$ and $170 \%$ to find optimum.

2. Tank 42 Sludge with HM levels of noble metals to bound response.

3. Complete Formic Acid Tank dump to bound response.

The bounding case of a complete acid tank dump needs to be repeated since the noble metals were low in the experiment done here and the hydrogen generation was still high. Once the bench-scale 
Westinghouse Savannah River Company

Savannah River Technology Center .
WSRC-TR-99-00111, Rev. 0

Page 25 of 111

experiments narrow the operating envelope for the CPC batch process, a series of $1 / 240^{\text {th }}$ scale large $\mathrm{CPC}$ batch runs should be completed in the Glass Feed Preparation System (GFPS). These GFPS experiments should include a pre-boiling acid and no pre-boiling acid run. These large-scale runs would give a better indication of processing problems like foaming since the bench-scale is limited to a mass flux of about $4 \mathrm{lb} / \mathrm{hr}^{*} \mathrm{ft}^{2}$ compared to DWPF's mass flux of about $50 \mathrm{lb} / \mathrm{hr}^{*} \mathrm{ft}^{2}$. The GFPS scale would also allow a more complete rheological study of the sludge slurry as it goes through the process, i.e. more samples could be taken at various points in the process. As discussed earlier, the large batch slurry is definitely thicker than a normal batch and needs to be clearly defined to make sure DWPF mixing is adequate. With a $T A$ Instruments rheometer these measurements would be quite easy, as only a 3-ml sample is needed. The larger.scale experiments would also give a better representation of potential processing problems such as fouling, foaming, mixing, and heat transfer problems.

The anecdotal evidence in these and earlier experiments suggest that as the sludge's weight percent solids increase (16-wt $\%$ to $20-w t \%)$ so does the required acid (137.5\% to $170 \%)$. Research should be done on the basis of the required acid calculation for some unknown variable or variables that are not being taken into consideration. For higher weight percent solids sludge (greater than 20 -wt $\%$ solids), it appears that more than the nominal $137.5 \%$ acid stoichiometry is needed for complete nitrite destruction by the end of the SRAT cycle. DWPF is currently using about $150 \%$ stoichiometry for the $17-w t \%$ solids sludge of Tank 42.

\section{ACKNOWLEDGMENTS}

Thanks to John Occhipinti for providing quick answers to our questions and direction as needed.

Thanks to Frances Williams, Sammie King, John Duvall, Mary Johnson, Vickie Williams for their help in preparing for and performing the experiments. Their work is very much appreciated. I appreciate the extra hours and long weekends the technicians worked to complete these experiments.

I would also like to thank the excellent technical support (as always) from Dan Lambert, Paul Monson, and especially Russ Eibling who performed the Rheology tests and provided the corresponding data.

Thanks to Nick Odom for assisting with the temperature controllers.

We appreciated the quick turnaround for sample analyses by the Mobile lab and ADS. 
Wéstinghouse Savannah River Company "

APPENDIX A-1: Heel Prep

WSRC-TR-99-00111, Rev. 0

Savannah River Technology Center

Page 26 of 111

\title{
APPENDIX A-1: LARGE BATCH SRAT HEEL PREPARATION
}

\author{
SRT-PTD-98-0016, Rev. 0 \\ CC: E. W. Holtzscheiter, 773-A \\ J. E. Occhipinti, 704-27S \\ S. L. Marra, 704-25S \\ R. E. Edwards, 704-25S \\ R. E. Eibling, 704-1T \\ P. R. Monson, 704-1T \\ D. P. Lambert, 704-1T \\ M. F. Williams, 704-1T \\ J. W. Duvall, 7.04-IT \\ M. L. Johnson, 772-T \\ S. O. King, 677-T \\ V. J. Williams, 677-T \\ D. C. Koopman, 704-T
}

November 20, 1998

TO: $\quad$ L. F. Landon, 704-1T

FROM: W. E. Daniel, 704-1T

\section{Run Plan for Large Batch Heel Preparation for Variability Runs for Developing Strategies for Increased CPC Batch Sizes (U)}

This run plan documents the preparation of the SRAT heel to be used in the variability runs for Developing Strategies for Increased CPC Batch Sizes as requested in DWPF Technical Task Request HLW/DWPT/TTR-980013. The experimental work will be controlled using the Laboratory Scale Chemical Process Cell Simulations (Manual L27, Procedure 2.02) and this run plan. The run plan includes many of the experimental details, the instructions for final sludge preparation, the scaling necessary for determining the operating conditions such as feed rates, purge rates, and the steps in completing the SRAT cycle. This document also summarizes the decisions made to complete these experiments.

1) The sludge used for the SRAT Heel preparation is a Tank 42-sludge simulant created from the Optima Tank 51 simulant with the following modifications.

a) A recipe is shown in Table XIII that targets a 20 weight percent solids sludge after the trim chemicals (noble metals and mercury) are added. This sludge will be referred to as Sludge $\mathrm{A}^{\prime}$ and its pre-trim measured as well as post-trim predicted elemental weight percent analyses are shown in Table XIV.

b) Purex levels of noble metals and mercury will be added to the sludge batch as shown in Table XV. This will require approximately 12 hours of refluxing in the SRAT to steam strip mercury and meet the DWPF constraint of $0.45 \mathrm{wt} \%$ mercury. 
Table XIII. Preparation Of Tank 42 Sludge 20 weight \% (Trim Chemicals Missing)

\begin{tabular}{|c|c|c|}
\hline Component & Amount, $g$ & Comments \\
\hline Tank 51 sludge simulant & 16521.36 & 18.52 wt\% solids initially \\
\hline Tank 51 supernate & 527.2 & Added Supernate to lower wt\% solids \\
\hline $\mathrm{Al}_{2} \mathrm{O}_{3}$ & 148.29 & \\
\hline $\left.\mathrm{Ni} \mathrm{NO}_{3}\right)_{2}{ }^{*} 6 \mathrm{H}_{2} \mathrm{O}$ & 30.22 & \\
\hline $\mathrm{SiO}_{2}$ & 53.48 & \\
\hline $\mathrm{MnO}_{2}{ }^{*} \mathrm{H}_{2} \mathrm{O}$ & 221.77 & Total Mass @27.2 wt\% solids \\
\hline $\mathrm{Water}^{\mathrm{Al}_{2} \mathrm{O}_{3}}$ & 200.00 & \\
\hline $\mathrm{Na}_{2} \mathrm{C}_{2} \mathrm{O}_{4}$ & 0.94 & \\
\hline $\mathrm{NaF}$ & 4.87 & \\
\hline $\mathrm{NaOH}$ & 0.66 & \\
\hline $\mathrm{NaCl}$ & 7.05 & \\
\hline & 0.82 & \\
\hline
\end{tabular}

Table XIV. Elemental Analyses of Large Batch 20 wt $\%$ Sludge $A^{\prime}$

\begin{tabular}{|c|c|c|c|c|c|}
\hline $\begin{array}{c}\text { Insoluble } \\
\text { Species }\end{array}$ & $\begin{array}{c}\text { Measured } \\
\text { Wt\% Solids } \\
\text { Pre-Trim }\end{array}$ & $\begin{array}{c}\text { Predicted Wt\% } \\
\text { Solids Post- } \\
\text { Trim }\end{array}$ & $\begin{array}{c}\text { Soluble } \\
\text { Species }\end{array}$ & $\begin{array}{c}\text { Measured } \\
\text { Wt\% Solids } \\
\text { Pre-Trim }\end{array}$ & $\begin{array}{c}\text { Predicted } \\
\text { Wt\% Solids } \\
\text { Post-Trim }\end{array}$ \\
\hline $\mathrm{Al}$ & $5.72 \%$ & $7.58 \%$ & $\mathrm{Al}$ & & $0.02 \%$ \\
\hline${ }^{*} \mathrm{Ag}$ & & $0.04 \%$ & $\mathrm{C} 2 \mathrm{O} 4$ & $0.28 \%$ & $0.27 \%$ \\
\hline $\mathrm{Ca}$ & $2.04 \%$ & $1.94 \%$ & $\mathrm{Cl}$ & $0.04 \%$ & $0.04 \%$ \\
\hline${ }^{*} \mathrm{Cd}$ & & $0.11 \%$ & $\mathrm{CO} 3$ & & $1.81 \%$ \\
\hline $\mathrm{Cl}$ & & $0.07 \%$ & $\mathrm{Cr}$ & & $0.00 \%$ \\
\hline $\mathrm{Cr}$ & & $0.16 \%$ & $\mathrm{~F}$ & $0.01 \%$ & $0.02 \%$ \\
\hline $\mathrm{Cu}$ & $0.02 \%$ & $0.02 \%$ & $\mathrm{~K}$ & & $0.00 \%$ \\
\hline $\mathrm{F}$ & & $0.01 \%$ & $\mathrm{Li}$ & & $0.00 \%$ \\
\hline $\mathrm{Fe}$ & $23.08 \%$ & $21.80 \%$ & $\mathrm{Na}$ & & $0.25 \%$ \\
\hline${ }^{*} \mathrm{Hg}$ & & $1.30 \%$ & $\mathrm{NO} 2$ & $4.38 \%$ & $3.73 \%$ \\
\hline $\mathrm{K}$ & $0.16 \%$ & $0.05 \%$ & $\mathrm{NO} 3$ & $1.80 \%$ & $1.44 \%$ \\
\hline $\mathrm{Li}$ & $0.00 \%$ & $0.00 \%$ & $\mathrm{OH}$ & & $0.12 \%$ \\
\hline $\mathrm{Mg}$ & $1.13 \%$ & $1.11 \%$ & $\mathrm{PO} 4$ & $0.06 \%$ & $0.05 \%$ \\
\hline $\mathrm{Mn}$ & $4.48 \%$ & $3.64 \%$ & $\mathrm{SO} 4$ & $0.26 \%$ & $0.21 \%$ \\
\hline $\mathrm{Na}$ & $7.88 \%$ & $5.74 \%$ & & & \\
\hline $\mathrm{Ni}$ & $0.35 \%$ & $0.34 \%$ & & & \\
\hline $\mathrm{P}$ & & $0.00 \%$ & & & \\
\hline${ }^{*} \mathrm{Pd}$ & & $0.00 \%$ & & & \\
\hline $\mathrm{Pu}$ & & $0.00 \%$ & & & \\
\hline${ }^{*} \mathrm{Rh}$ & & $0.01 \%$ & & & \\
\hline${ }^{*} \mathrm{Ru}$ & & $0.02 \%$ & & & \\
\hline $\mathrm{Se}$ & & $0.00 \%$ & & & \\
\hline $\mathrm{Si}$ & $1.64 \%$ & $1.80 \%$ & & & \\
\hline $\mathrm{Te}$ & & $0.00 \%$ & & & \\
\hline $\mathrm{Ti}$ & $0.05 \%$ & $0.05 \%$ & & & \\
\hline $\mathrm{U}$ & & $0.00 \%$ & & & \\
\hline $\mathrm{Zn}$ & $0.01 \%$ & 0.00 & & & \\
\hline & & & & & \\
\hline
\end{tabular}


Table XV. Trim Chemical Addition for Large Batch SRAT Heel Preparation

\begin{tabular}{|c|c|c|c|c|c|}
\hline & $\begin{array}{c}\text { Target } \\
\text { Addition, }\end{array}$ & $\begin{array}{c}\text { Actual } \\
\text { Addition, }\end{array}$ & Wt\% Solids & $\begin{array}{c}\text { Target } \\
\text { Solids, g }\end{array}$ & $\begin{array}{c}\text { Actual } \\
\text { Solids } \\
\text { added, } g\end{array}$ \\
\hline Sludge & 3200.0 & 3200.0 & $19.3 \%$ & 617.6 & 617.6 \\
\hline Trim Chemicals & $\begin{array}{c}\text { Target } \\
\text { Addition, } \\
\text { grams }\end{array}$ & $\begin{array}{c}\text { Actual } \\
\text { Addition, } \\
\text { grams }\end{array}$ & $\begin{array}{c}\text { Elemental } \\
\text { Solids Factor }\end{array}$ & $\begin{array}{c}\text { Target } \\
\text { Elemental } \\
\text { Solids, g }\end{array}$ & $\begin{array}{c}\text { Actual } \\
\text { Elemental } \\
\text { Solids, g. }\end{array}$ \\
\hline $\mathrm{AgNO3}$ & 0.360 & 0.3606 & 0.6349 & 0.229 & 0.229 \\
\hline $\mathrm{Cd}(\mathrm{NO} 3)^{*} 4 \mathrm{H} 2 \mathrm{O}$ & 1.864 & 0.0000 & 0.3644 & 0.679 & 0.000 \\
\hline $\mathrm{HgO}$ & 8.669 & 8.6694 & 0.9261 & 8.029 & 8.029 \\
\hline $\mathrm{Pd}(\mathrm{NO} 3) 2^{*} \mathrm{H} 2 \mathrm{O}$ & 0.032 & 0.0323 & $0.1527^{\dagger}$ & 0.014 & $0.014^{\dagger}$ \\
\hline $\mathrm{Rh}(\mathrm{NO} 3)^{*} 2 \mathrm{H} 2 \mathrm{O}$ & 0.103 & 0.1034 & $0.0493^{\dagger}$ & 0.033 & $0.033^{\dagger}$ \\
\hline $\mathrm{RuCl} 3$ & 0.279 & 0.2795 & $0.4174^{\dagger}$ & 0.136 & $0.136^{\dagger}$ \\
\hline
\end{tabular}

\begin{tabular}{|c|c|c|}
\hline Element & $\begin{array}{c}\text { Target Wt\% } \\
\text { Solids }\end{array}$ & $\begin{array}{c}\text { Actual Wt\% } \\
\text { Solids. }\end{array}$ \\
\hline $\mathrm{Ag}$ & $0.04 \%$ & $0.04 \%$ \\
\hline $\mathrm{Cd}$ & $0.11 \%$ & $0.00 \%$ \\
\hline $\mathrm{Hg}$ & $1.30 \%$ & $1.30 \%$ \\
\hline $\mathrm{Pd}$ & $0.0022 \%$ & $0.0008 \%^{\dagger}$ \\
\hline $\mathrm{Rh}$ & $0.0053 \%$ & $0.0008 \%^{\dagger}$ \\
\hline $\mathrm{Ru}$ & $0.02 \%$ & $0.019 \%^{\dagger}$ \\
\hline
\end{tabular}

†Values changed from original run plan to reflect noble metal under addition.

2) Calculated acid addition rates, boilup rates, purge rates, antifoam addition, etc. were based on scaling from DWPF settings as shown in Table XVI.

3) The acid additions were determined for $125 \%$ of stoichiometry with a redox target of $0.2 \mathrm{Fe}^{+2} / \Sigma \mathrm{Fe}$. The redox calculation spreadsheet for the large batch heel are shown in Table XVII.

4) A review, as required by the Conduct of Research and Development has been completed.

5) The experiments are planned to be completed the week of November 23, 1998. 
Table XVI. Scaling Calculations for Large Batch SRAT Heel Preparation

\begin{tabular}{|c|c|c|c|}
\hline & DWPF & TNX 1W & Time \\
\hline Scale factor & 1 & $7,097(8019)^{\dagger}$ & \\
\hline Sludge Added Volume & $6,000 \mathrm{gal}$ & $2832 \mathrm{ml}$ & \\
\hline Sludge Added Density & 1.13 & 1.13 & \\
\hline Sludge Added Mass & $25664 \mathrm{~kg}$ & $3200.0 \mathrm{~g}$ & \\
\hline SRAT Added Water & $0 \mathrm{gal}$ & $0.0 \mathrm{ml}$ & \\
\hline SRAT purge air & $188 \mathrm{scfm}$ & $750.1 \mathrm{scc} / \mathrm{min}$ & \\
\hline SME purge air & $66 \mathrm{scfm}$ & $263.3 \mathrm{scc} / \mathrm{min}$ & \\
\hline $\begin{array}{c}\text { Antifoam (100 ppm in } \\
\text { Total Sludge) }\end{array}$ & $5.66 \mathrm{lbs}$ & $0.32 \mathrm{~g}$ & \\
\hline $\begin{array}{c}\text { Antifoam Solution }(20 \text { to } 1 \\
\text { solution) }\end{array}$ & $113.16 \mathrm{lbs}$ & $6.40 \mathrm{~g}$ & \\
\hline nitric acid feedrate & $: 2 \mathrm{gpm}$ & $1.062 \mathrm{ml} / \mathrm{min}$ & $2.3 \mathrm{hrs}$ \\
\hline formic acid feedrate & $2 \mathrm{gpm}$ & $1.067 \mathrm{ml} / \mathrm{min}$ & $1.1 \mathrm{hrs}$ \\
\hline Boilup rate & $5,000 \mathrm{lb} / \mathrm{hr}$ & $5.33 \mathrm{~g} / \mathrm{min}$ & \\
\hline & & & \\
\hline Formic Molarity & $23.55 \mathrm{M}$ & $23.55 \mathrm{M}$ & \\
\hline Nitric Molarity & $10.35 \mathrm{M}$ & $10.40 \mathrm{M}$ & \\
\hline & & & \\
\hline Formic Volume & $269.2 \mathrm{gal}$ & $143.61 \mathrm{ml}$ & \\
\hline Formic Mass & & $172.96 \mathrm{~g}$ & \\
\hline Nitric Volume & $133.6 \mathrm{gal}$ & $70.90 \mathrm{ml}$ & \\
\hline Nitric Mass & & $92.92 \mathrm{~g}$ & \\
\hline Formic feed time & $134.6 \mathrm{~min}$ & $134.6 \mathrm{~min}$ & \\
\hline Nitric feed time & $66.8 \mathrm{~min}$ & $66.8 \mathrm{~min}$ & \\
\hline & & & \\
\hline Total Volume & & $3046.37 \mathrm{ml}$ & \\
\hline Corec sclacl & & & \\
\hline
\end{tabular}

${ }^{\top}$ Correct scale factor in parentheses, value off due to improper density correction. 
Weștinghouse Savannah River Company Savannah River Technology Center
WSRC-TR-99-00111, Rev. 0

Page 30 of 111

Table XVII. Large Batch SRAT Heel Preparation Redox Calculation

Stoichiometry ratio

$125.0 \%(141 \%)^{\dagger}$

Date: $\quad 11 / 20 / 98$

\begin{tabular}{|c|c|c|c|c|c|}
\hline $\begin{array}{c}\text { Stream } \\
\end{array}$ & PHA & Sludge & Frit & SME & \\
\hline Oxide Contribution (\%) (in SME) & $0.0 \%$ & $26.0 \%$ & $74.0 \%$ & 15399.2 & $" \mathrm{~kg}$ Calc. Basis \\
\hline Density $(\mathrm{kg} / \mathrm{L})$ & 1.0355 & 1.130 & $n / a$ & $137.0 \%$ & \\
\hline Total Solids (\%) & $5.38 \%$ & $19.30 \%$ & $n / a$ & $48.0 \%$ & \\
\hline Calcine Factor (ox/sol) & 1.00 & 0.81 & $n / a$ & $n / a$ & \\
\hline Hydroxide (M) & $n / a$ & 0.646 & $n / a$ & $n / a$ & \\
\hline Mercury (ppm) & $n / a$ & 2509.0 & $n / a$ & $n / a$ & \\
\hline Total Mn (wt\% solids) & $n / a$ & 4.48 & $n / a$ & $n / a$ & \\
\hline Soluble Mn (ppm) & $n / a$ & 0.00 & $n / a$ & $n / a$ & \\
\hline *TIC (ppm) & $n / a$ & 0.00 & $n / a$ & n/a & \\
\hline Total Acid (M) & 0.240 & $n / a$ & $n / a$ & na & \\
\hline Nitrite (ppm) & 0.0 & 8452.0 & $0.0(\mathrm{~kg} / 100 \mathrm{~kg}$ frit $)$ & & \\
\hline NO2 Destruction & $0.0 \%$ & $100.0 \%$ & $0.0 \%$ & & \\
\hline Nitrate (ppm) & 1012.1 & 3466.0 & $0.0(\mathrm{~kg} / 100 \mathrm{~kg}$ frit $)$ & & \\
\hline$\%$ nitrite to nitrate conversion & & $35.0 \%$ & & & \\
\hline Formate (ppm) & 22808.9 & 0.0 & $1.0(\mathrm{~kg} / 100 \mathrm{~kg}$ frit $)$ & & \\
\hline Reaction formate destruction, $\mathrm{kg}$ & & 140.25 & & & \\
\hline Factor for total formate destruction & & $15.0 \%$ & & & \\
\hline Total formate destruction, $\mathrm{kg}$ & & 21.04 & & & \\
\hline Oxide Mass (kg) & 0.0 & 4003.8 & 11395.4 & 15399.2 & \\
\hline Solids Mass (kg) & 0.00 & 4953.40 & 11395.39 & 16348.79 & \\
\hline Total Mass (kg) & 0.00 & 25665.29 & $n / a$ & 34059.98 & \\
\hline Volume (L) & 0.00 & $22,712.65$ & $n / a$ & 24861.30 & \\
\hline \% Stoichiometry & $n / a$ & $125.0 \%$ & $n / a$ & $n / a$ & \\
\hline Volume HNO3@50\% (L) & $n / a$ & 2.824 .87 & $n / a$ & $n^{\prime} a$ & \\
\hline NO2 Contribution (kg) & 0.000 & 216.923 & 0.000 & 216.923 & \\
\hline NO2 Remaining (kg) & 0.000 & 0.000 & 0.000 & 0.000 & \\
\hline NO3 Contribution (kg) & 0.000 & 1977.649 & 0.000 & 1977.649 & \\
\hline $\mathrm{COOH}$ Contribution $(\mathrm{kg})$ & 0.000 & -140.25 & 93.843 & -46.41 & \\
\hline NO2 (Molar@45\%) & & & & 0.000 & \\
\hline NO3 (Molar@45\%) & & & & 1.352 & \\
\hline COOH (Molar@45\%) & & & & -0.044 & \\
\hline Predicted $\mathrm{Fe}(\mathrm{II}) / \mathrm{QFe}$ & & & 0.09 & BDL@0.03 & $\leq 0.1$ \\
\hline Volume HCOOH@90\% (L) & & & 3442.56 & 3167.03 & 3488.54 \\
\hline$\%$ Stoichiometry & $n / a$ & $125.0 \%$ & $n / a$ & $n / a$ & \\
\hline Volume HCOOH@90\% (L) & $n / a$ & $1,241.38$ & $n / a$ & $n / a$ & \\
\hline NO2 Contribution (kg) & 0.000 & 216.923 & 0.000 & 216.923 & \\
\hline NO2 Remaining (kg) & 0.000 & 0.000 & 0.000 & 0.000 & \\
\hline NO3 Contribution (kg) & 0.000 & 164.879 & 0.000 & 164.879 & \\
\hline $\mathrm{COOH}$ Contribution (kg) & 0.000 & 1295.096 & 93.843 & 1388.940 & \\
\hline NO2 (Molar@45\%) & & & & 0.000 & \\
\hline NO3 (Molar@45\%) & & $\cdot$ & & 0.113 & \\
\hline COOH (Molar@45\%) & & & & 1.308 & \\
\hline Predicted Fe(II)/OFe & & & 0.09 & 0.468 & $\leq 0.1$ \\
\hline Volume HNO3@50\%(L) & & & 1221.59 & & 1186.77 \\
\hline
\end{tabular}

$\dagger$ Value in parentheses represents corrected value due to scale factor error. 
Table XVII. Large Batch SRAT Heel Preparation Redox Calculation Continued

\begin{tabular}{|l|rrrr|}
\hline mol\% Nitric & n/a & $17.9 \%$ & $n / a$ & $n / a$ \\
Volume HCOOH@90\%(L) & $n / a$ & $1,019.17$ & $n / a$ & $n / a$ \\
Volume HNO3@50\%(L) & & 505.65 & & 216.923 \\
NO2 Contribution (kg) & 0.000 & 216.923 & 0.000 & 0.000 \\
NO2 Remaining (kg) & 0.000 & 0.000 & 0.000 & 489.365 \\
NO3 Contribution (kg) & 0.000 & 489.365 & 0.000 & 940.291 \\
COOH Contribution (kg) & 0.000 & 940.291 & 0.000 & 0.000 \\
NO2 (Molar@45\%) & & & & 0.335 \\
NO3 (Molar@45\%) & & & & 0.886 \\
COOH (Molar@45\%) & & & & 0.09 \\
Predicted Fe(II)/DFe & & & $0.200(0.211)^{\dagger} \leq 0.1$ \\
\hline
\end{tabular}


Westinghouse Savannah River Company Savannah River Technology Center
APPENDIX A-1: Heel Prep

WSRC-TR-99-00111, Rev. 0

Page 32 of 111

Date: $11 / 23 / 98$

Run \# Large CPC Heel

\section{PREREQUISITES}

1. $\forall$ Signed TAR requesting work.

2. Mssued Testing scope and task assignment.

3. Analyze sludge for density, total base (pH 5.5), nitrate, manganese, nitrite, density, solids.'

4. Calibrate GC. Calibrate for nitrogen, oxygen, $\mathrm{N} 2 \mathrm{O}$, hydrogen, and carbon dioxide.

5. Prepare sufficient $90 \%$ formic acid and $50 \%$ nitric acid.

6. Dprepare sufficient antifoam solution or make sure sufficient solution is available.

7. Calculate batching and scaling for experiment based on DWPF parameters.

8. Calculate redox for experiment based on DWPF parameters.

9. Wetup experimental rig per sketch below.

10. Complete leak check and water run.

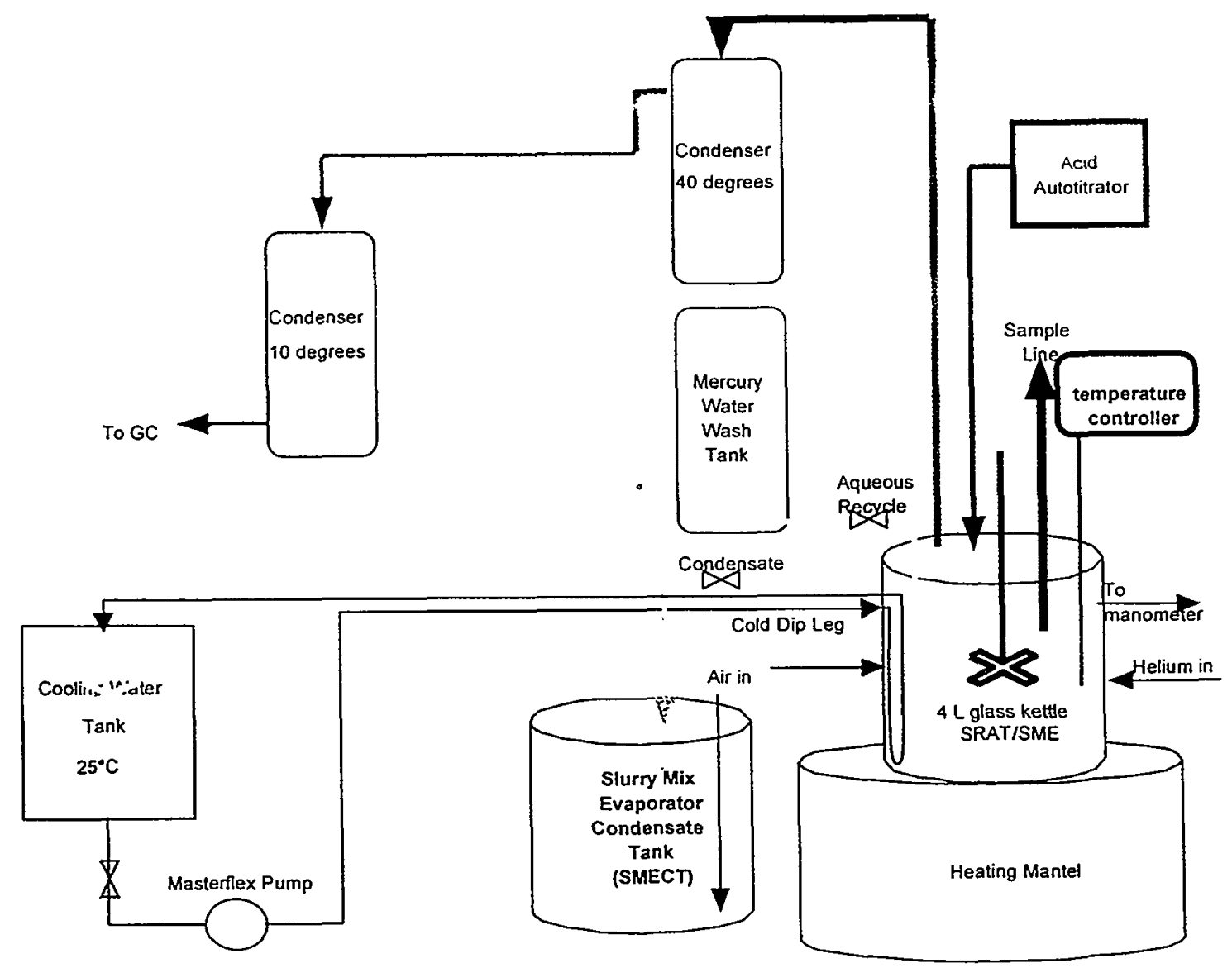




\section{PREPARATION FOR SRAT CYCLE}

Note: po not insulate kettle until acid addition is complete

1. $\mathbb{A}$ Add $3200 \mathrm{~g}$ of Sludge $\mathrm{A}^{\prime}$ to kettle.

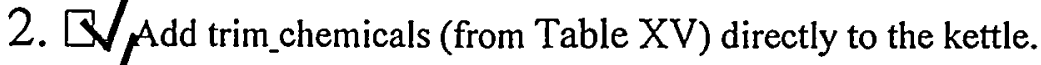

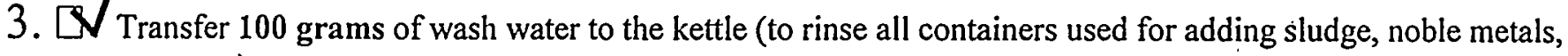
mepury, etc.).

4. $\mathrm{W}$ Calibrate $\mathrm{pH}$ probe with $\mathrm{pH} 4$ and 10 buffer. Record measured $\mathrm{pH}$ of $\mathrm{pH} 7$ buffer $\_.125$.

5. $\mathrm{W}$, Install $\mathrm{pH}$ probe in kettle. Record initial pH of sludge 11.827

6. $\mathbb{V}$ Turn on the air purge to kettle at $750.1 \mathrm{sccm}$. Connect the outlet flowmeter to perform the leak check. The outlet flow should be 700-800 sccm. If it is not, tighten all connections until the system is leak tight. Write down the feak check in the logbook.

7. $\$$ Disconnect outlet flowmeter.

8. $\square$ Turn on kettle agitator. Setpoint $=150 \mathbf{~ r p m}$.

9. $\mathbb{V}$ Turn on cooling water to SRAT condenser. Setpoint $=40^{\circ} \mathrm{C}$.

10. VTurn on cooling water to Chilled (FAVC) condenser. Setpoint $=5^{\circ} \mathrm{C}$.

11. Make sure the GC computer has enough memory space for the run (at least 40 Mbyte).

12. Set the GC computer time equal to the clock time. Record the time in the log book.

13. Install the calibration gas cylinder to the GC and let the GC run five times. If at the end of five runs the GC reading is within $10 \%$ of the gas composition in the cylinder, print the calibration check results and write down "pre-cal check and run number" on the printout. Otherwise, select "Calibration" "Level I" "OK" to calibrate the GC five times. At the end of five runs the GC reading should be within $10 \%$ of the gas composition in the cylinder. If it is not, contact the engineer. Print the calibration check results and write Alown "pre-cal check and run number" on the printout.

14. Start the GC for this run beginning with baseline reading for a few minutes. Write down the GC time, filename etc. in the logbook. Record the baseline data on the data sheet. 
Weștinghouse Savannah River Company Savannah River Technology Center

Run \# Large CPC Heel
APPENDIX A-1: Heel Prep

\author{
Date: $11 / 24 / 98$
}

\section{SRAT CXCLE}

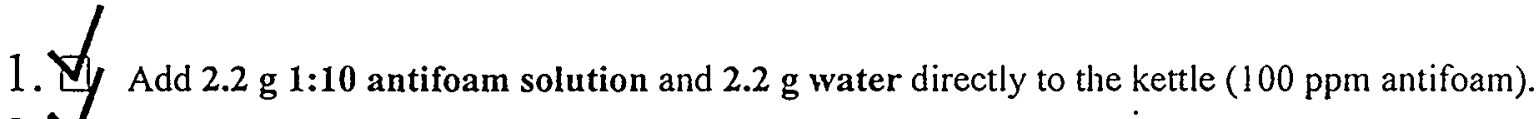

2. Start heating the kettle (Turn on power, setpoint at $93^{\circ} \mathrm{C}$ ). Record the run data every 20 minutes on the data sheet.

3. Add $70.90 \mathrm{ml}$ of 50-wt\% nitric acid @ $1.062 \mathrm{ml} / \mathrm{min}$ (reference Table XVI) to the kettle.

4. Add $143.61 \mathrm{ml}$ of $90 \%$ formic acid@1.067 ml/min (reference Table XVI) to the kettle.

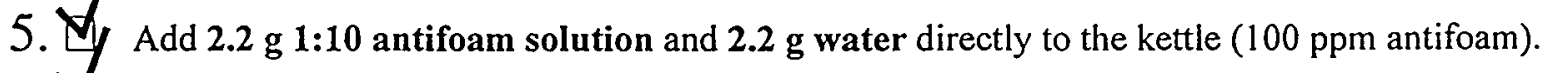

6. Bring kettle contents to boiling. If slurry begins to foam over, switch off heating and turn on the cooling coil water pump to bring the temperature down rapidly. Then switch off the cooling coil water pump and

7. Slowly heat up the kettle again to the point of boiling.
Dewater until kettle volume is approximately $3.2 \mathrm{~L}$. (Boiled off $323 \mathrm{~g}$ )

8. Reflux the slurry for 12 hours at $5.33 \mathrm{~g} / \mathrm{min}$ boil-up, then turn off the heat to cool the kettle to sub-boiling.

9. Pull a $125 \mathrm{ml}$ sample (LB SRAT Heel) from the kettle, record the weight on the run sheet. Label and send to lab for analyses. 
Westinghouse Savannah River Company Savannah River Technology Center
APPENDIX A-2: Heel Prep 2

WSRC-TR-99-00111, Rev. 0

Page 35 of 111

\title{
APPENDIX A-2: LARGE BATCH SRAT HEEL PREPARATION 2
}

\author{
SRT-PTD-99-0029, Rev. 1 \\ CC: $\quad$ E. W. Holtzscheiter, 773-A \\ J. E. Occhipinti, 704-27S \\ S. L. Marra, 704-T \\ R. E. Edwards, 704-25S \\ R. E. Eibling, 704-1T \\ P. R. Monson, 704-1T \\ D. P. Lambert, 704-1T \\ M. F. Williams, 704-1T \\ J. W. Duvall, 704-1T \\ M. L. Johnson, 772-T \\ S. O. King, 677-T \\ V. J. Williams, 677-T \\ D. C. Koopman, 704-T \\ T. O. Burckhalter, 677-T
}

June 15, 1999

TO: $\quad$ L. F. Landon, 704-1T

FROM: $\quad$ W. E. Daniel, 704-1T

Run Plan for Large Batch Heel Preparation for Extra Variability Run for Increased CPC Batch Size Study (U)

This run plan documents the preparation of a SRAT heel to be used in an extra variability run for Developing Strategies for Increased CPC Batch Sizes as requested in DWPF. Technical Task Request HLW/DWPT/TTR-980013. The experimental work will be controlled using the Laboratory Scale Chemical Process Cell Simulations (Manual L27, Procedure 2.02) and this run plan. The run plan includes many of the experimental details, the instructions for final sludge preparation, the scaling necessary for determining the operating conditions such as feed rates, purge rates, and the steps in completing the SRAT cycle. This document also summarizes the decisions made to complete these experiments.

1) The sludge used for the SRAT Heel preparation is a Tank 42-sludge simulant created from the Optima Tank 51 simulant with the following modifications.

a) A recipe is shown in Table XVIII that targets a 20 weight percent solids sludge after the trim chemicals (noble metals and mercury) are added. This sludge will be referred to as Sludge $A^{\prime}$ and its pre-trim measured as well as post-trim predicted elemental weight percent analyses are shown in Table XIX.

b) Purex levels of noble metals and mercury will be added to the sludge batch as shown in Table XX. This will require approximately 13 hours of refluxing in the SRAT to steam strip mercury and meet the DWPF constraint of $0.45 \mathrm{wt} \%$ mercury. 
Westinghouse Savannah River Company

Savannah River Technology Center

Table XVIII. Preparation Of Tank 42 Sludge 20 weight \% (Trim Chemicals Missing)

\begin{tabular}{|c|c|c|}
\hline Component & Amount, & Comments \\
\hline Tank 51 sludge simulant & 16521.36 & 18.52 wt\% solids initially \\
\hline Tank 51 supernate & 527.2 & Added Supernate to lower wt\% solids \\
\hline $\mathrm{Al}_{2} \mathrm{O}_{3}$ & 148.29 & \\
\hline $\mathrm{Ni}\left(\mathrm{NO}_{3}\right)_{2}{ }^{*} 6 \mathrm{H}_{2} \mathrm{O}$ & 30.22 & \\
\hline $\mathrm{SiO}_{2}$ & 53.48 & \\
\hline $\mathrm{MnO}_{2}{ }^{*} \mathrm{H} \mathrm{H}_{2} \mathrm{O}$ & 221.77 & Total Mass @ 27.2 wt\% solids \\
\hline $\mathrm{Water}_{\mathrm{Al}_{2} \mathrm{O}_{3}}$ & 200.00 & \\
\hline $\mathrm{Na}_{2} \mathrm{C}_{2} \mathrm{O}_{4}$ & 0.94 & \\
\hline $\mathrm{NaF}$ & 4.87 & \\
\hline $\mathrm{NaOH}$ & 0.66 & \\
\hline $\mathrm{NaCl}$ & 7.05 & \\
\hline
\end{tabular}

Table XIX. Elemental Analyses of Large Batch 20 wt\% Sludge A'

\begin{tabular}{|c|c|c|c|c|c|}
\hline $\begin{array}{l}\text { Insoluble } \\
\text { Species }\end{array}$ & $\begin{array}{l}\text { Measured } \\
\text { Wt\% Solids } \\
\text { Pre-Trim }\end{array}$ & \begin{tabular}{|c|} 
Predicted Wt\% \\
Solids Post- \\
Trim
\end{tabular} & $\begin{array}{l}\text { Soluble } \\
\text { Species }\end{array}$ & $\begin{array}{c}\text { Measured } \\
\text { Wt\% Solids } \\
\text { Pre-Trim }\end{array}$ & \begin{tabular}{|c|} 
Predicted \\
Wt $\%$ \\
Solids Post- \\
Trim \\
\end{tabular} \\
\hline $\mathrm{Al}$ & $5.72 \%$ & $7.58 \%$ & $\mathrm{Al}$ & & $0.02 \%$ \\
\hline${ }^{*} \mathrm{Ag}$ & & $0.04 \%$ & $\mathrm{C} 2 \mathrm{O} 4$ & $0.28 \%$ & $0.27 \%$ \\
\hline $\mathrm{Ca}$ & $2.04 \%$ & $1.94 \%$ & $\mathrm{Cl}$ & $0.04 \%$ & $0.04 \%$ \\
\hline${ }^{*} \mathrm{Cd}$ & & $0.11 \%$ & $\mathrm{CO} 3$ & & $1.81 \%$ \\
\hline $\mathrm{Cl}$ & & $0.07 \%$ & $\mathrm{Cr}$ & & $0.00 \%$ \\
\hline $\mathrm{Cr}$ & & $0.16 \%$ & $\mathrm{~F}$ & $0.01 \%$ & $0.02 \%$ \\
\hline $\mathrm{Cu}$ & $0.02 \%$ & $0.02 \%$ & $\mathrm{~K}$ & & $0.00 \%$ \\
\hline $\mathrm{F}$ & & $0.01 \%$ & $\mathrm{Li}$ & & $0.00 \%$ \\
\hline $\mathrm{Fe}$ & $23.08 \%$ & $21.80 \%$ & $\mathrm{Na}$ & & $0.25 \%$ \\
\hline${ }^{*} \mathrm{Hg}$ & & $1.30 \%$ & $\mathrm{NO} 2$ & $4.38 \%$ & $3.73 \%$ \\
\hline $\mathrm{K}$ & $0.16 \%$ & $0.05 \%$ & NO3 & $1.80 \%$ & $1.44 \%$ \\
\hline $\mathrm{Li}$ & $0.00 \%$ & $0.00 \%$ & $\mathrm{OH}$ & & $0.12 \%$ \\
\hline $\mathrm{Mg}$ & $1.13 \%$ & $1.11 \%$ & PO4 & $0.06 \%$ & $0.05 \%$ \\
\hline $\mathrm{Mn}$ & $4.48 \%$ & $3.64 \%$ & $\mathrm{SO} 4$ & $0.26 \%$ & $0.21 \%$ \\
\hline $\mathrm{Na}$ & $7.88 \%$ & $5.74 \%$ & & & \\
\hline $\mathrm{Ni}$ & $0.35 \%$ & $0.34 \%$ & & & \\
\hline $\mathrm{P}$ & & $0.00 \%$ & & & \\
\hline${ }^{*} \mathrm{Pd}$ & & $0.00 \%$ & & & \\
\hline $\mathrm{Pu}$ & & $0.00 \%$ & & & \\
\hline$* \mathrm{Rh}$ & 1 & $0.01 \%$ & & & \\
\hline$* \mathrm{Ru}$ & & $0.02 \%$ & & & \\
\hline $\mathrm{Se}$ & & $0.00 \%$ & & & \\
\hline $\mathrm{Si}$ & $1.64 \%$ & $1.80 \%$ & & & \\
\hline $\mathrm{Te}$ & & $0.00 \%$ & & & \\
\hline $\mathrm{Ti}$ & $0.05 \%$ & $0.05 \%$ & & & \\
\hline $\mathrm{U}$ & & $0.00 \%$ & & & \\
\hline $\mathrm{Zn}$ & $0.01 \%$ & 0.00 & & & \\
\hline
\end{tabular}


Table XX. Trim Chemical Addition for Large Batch SRAT Heel 2 Preparation

\begin{tabular}{|c|c|c|c|c|c|c|}
\hline & & $\begin{array}{c}\text { Target } \\
\text { Addition, } \mathrm{g}\end{array}$ & $\begin{array}{c}\text { Actual } \\
\text { Addition, } g\end{array}$ & $\begin{array}{c}\text { Wt } \% \text { Solids w/o } \\
\text { Trim }\end{array}$ & $\begin{array}{l}\text { Target Solids } \\
\text { w/Trim, } \mathrm{g}^{9}\end{array}$ & $\begin{array}{l}\text { Actual Solids } \\
\text { added, } \mathrm{g}^{9}\end{array}$ \\
\hline Sludge $A^{\prime}$ & & 2100.0 & 2100.0 & $19.3 \%$ & 423.6 & 423.6 \\
\hline Trim Chemicals & $\begin{array}{l}\text { Wt } \% \text { Species in } \\
\text { Solution }\end{array}$ & \begin{tabular}{c|} 
Target \\
Addition, grams
\end{tabular} & $\begin{array}{c}\text { Actual } \\
\text { Addition, } \\
\text { grams }\end{array}$ & $\begin{array}{c}\text { Elemental } \\
\text { Solids Factor }\end{array}$ & $\begin{array}{l}\text { Target Elemental } \\
\text { Solids, } \mathrm{g}\end{array}$ & $\begin{array}{c}\text { Actual } \\
\text { Elemental } \\
\text { Solids, } \mathrm{g}\end{array}$ \\
\hline AgNO3 & $100.00 \%$ & 0.252 & 0.254 & 0.6349 & 0.160 & 0.161 \\
\hline $\mathrm{HgO}$ & $100.00 \%$ & 5.885 & 5.8852 & 0.9261 & 5.450 & 5.450 \\
\hline $\mathrm{Pd}(\mathrm{NO} 3) 2^{*} \mathrm{H} 2 \mathrm{O}$ & $15.27 \%^{8}$ & 0.061 & 0.0609 & 0.1527 & 0.0093 & 0.0093 \\
\hline $\mathrm{Rh}(\mathrm{NO} 3) 3^{*} 2 \mathrm{H} 2 \mathrm{O}$ & $4.93 \%^{8}$ & 0.452 & 0.4526 & 0.0493 & 0.0223 & 0.0223 \\
\hline $\mathrm{RuCl} 3$ & $41.74 \%^{8}$ & 0.220 & 0.2197 & 0.4174 & 0.0920 & 0.0917 \\
\hline $\mathrm{Cd}(\mathrm{NO} 3) 2 * 4 \mathrm{H} 2 \mathrm{O}$ & $100.00 \%^{8}$ & 1.262 & 1.2649 . & 0.3644 & 0.460 & 0.461 \\
\hline
\end{tabular}

\begin{tabular}{|c|c|c|c|}
\hline Element & & $\begin{array}{c}\text { Target Wt\% } \\
\text { Solids }^{9}\end{array}$ & $\begin{array}{c}\text { Actual Wt\% } \\
\text { Solids }\end{array}$ \\
\hline $\mathrm{Ag}$ & & $0.04 \%$ & $0.04 \%$ \\
\hline $\mathrm{Hg}$ & & $1.30 \%$ & $1.30 \%$ \\
\hline $\mathrm{Pd}$ & & $0.0022 \%$ & $0.0022 \%$ \\
\hline $\mathrm{Rh}$ & & $0.0053 \%$ & $0.0053 \%$ \\
\hline $\mathrm{Ru}$ & & $0.022 \%$ & $0.022 \%$ \\
\hline $\mathrm{Cd}$ & & $0.11 \%$ & $0.11 \%$ \\
\hline
\end{tabular}

2) Calculated acid addition rates, boilup rates, purge rates, antifoam addition, etc. were based on scaling from DWPF settings as shown in Table XXI.

3) The acid additions were determined for $125 \%$ of stoichiometry with a redox target of $0.2 \mathrm{Fe}^{+2} / \Sigma \mathrm{Fe}$. The redox calculation spreadsheet for the large batch heel are shown in Table XXII.

4) A review, as required by the Conduct of Research and Development has been completed.

5) The experiments are planned to be completed the week of June 14, 1999.

${ }^{8}$ These values represent the weight percent of elemental $\mathrm{Pd}, \mathrm{Rh}$, or $\mathrm{Ru}$ in their respective solutions.

${ }^{9}$ These values include the weight and/or solids of the added trim chemicals. 
Table XXI. Scaling Calculations for Large Batch SRAT Heel 2 Preparation

\begin{tabular}{|c|c|c|c|}
\hline & DWPF & TNX LBH2 & Time \\
\hline Scale factor & 1 & $10,814(12220)^{\dagger}$ & \\
\hline Sludge Added Volume & $6,000 \mathrm{gal}$ & $1858 \mathrm{ml}$ & \\
\hline Sludge Heel Volume & $0 \mathrm{gal}$ & $0 \mathrm{ml}$ & \\
\hline Sludge Added Density & 1.13 & 1.13 & \\
\hline Sludge Heel Density & 1.15 & 1.15 & \\
\hline Sludge Added Mass & $25664 \mathrm{~kg}$ & $2100.0 \mathrm{~g}$ & \\
\hline Sludge Heel Mass & $0 \mathrm{~kg}$ & $0.0 \mathrm{~g}$ & \\
\hline SRAT Added Water & $1,000 \mathrm{gal}$ & $309.7 \mathrm{ml}$ & $2.2 \mathrm{hrs} \mathrm{boil}$ \\
\hline SRAT purge air & $188 \mathrm{scfm}$ & $489.8 \mathrm{scc} / \mathrm{min}$ & \\
\hline SRAT He purge & $0.50 \mathrm{vol} \%$ & $2.46 \mathrm{scc} / \mathrm{min}$ & \\
\hline SME purge air & $66 \mathrm{scfm}$ & $172.0 \mathrm{scc} / \mathrm{min}$ & \\
\hline SME He purge & $0.50 \mathrm{vol} \%$ & $0.86 \mathrm{scc} / \mathrm{min}$ & \\
\hline & & & \\
\hline Antifoam (100 ppm in & $5.66 \mathrm{lbs}$ & $0.21 \mathrm{~g}$ & \\
\hline Total Sludge) & & & \\
\hline Antifoam Solution (20 to & $113.16 \mathrm{lbs}$ & $4.20 \mathrm{~g}$ & \\
\hline 1 solution) & & & \\
\hline nitric acid feedrate & $2 \mathrm{gpm}$ & $0.697 \mathrm{ml} / \mathrm{min}$ & $1.0 \mathrm{hrs} \mathrm{feed}$ \\
\hline formic acid feedrate & $2 \mathrm{gpm}$ & $0.700 \mathrm{ml} / \mathrm{min}$ & $2.5 \mathrm{hrs} \mathrm{feed}$ \\
\hline boilup rate & $5,000 \mathrm{lb} / \mathrm{hr}$ & $3.50 \mathrm{~g} / \mathrm{min}$ & \\
\hline & & & \\
\hline Formic Molarity & $23.55 \mathrm{M}$ & $21.3 \mathrm{M}$ & \\
\hline Nitric Molarity & $10.35 \mathrm{M}$ & $10.40 \mathrm{M}$ & \\
\hline & & & \\
\hline Formic Volume & $270.6 \mathrm{gal}$ & $104.74 \mathrm{ml}$ & \\
\hline Formic Mass & & $126.15 \mathrm{~g}$ & \\
\hline Nitric Volume & $134.3 \mathrm{gal}$ & $46.77 \mathrm{ml}$ & \\
\hline Nitric Mass & & $61.30 \mathrm{~g}$ & \\
\hline formic feed time & $135.3 \mathrm{~min}$ & $135.3 \mathrm{~min}$ & \\
\hline Nitric feed time & $67.1 \mathrm{~min}$ & $67.1 \mathrm{~min}$ & \\
\hline Total Vol & & $2319.66 \mathrm{ml}$ & \\
\hline Cor & & & \\
\hline
\end{tabular}

${ }^{t}$ Correct scale factor in parentheses, value off due to improper density correction.

${ }^{\ddagger}$ Actual SRAT/SME Gas Purge equivalent to this Air purge plus the Helium Purge. 
Weștinghouse Savannah River Company Savannah River Technology Center
APPENDIX A-2: Heel Prep 2
WSRC-TR-99-00111, Rev. 0

Page 39 of 111

Table XXII. Large Batch SRAT Heel Preparation Redox Calculation

Stoichiometry ratio $125.0 \%(140 \%)^{\dagger}$

Date: . $6 / 15 / 99$

\begin{tabular}{|c|c|c|c|c|c|}
\hline Stream & PHA & Sludge & Frit & SME & \\
\hline Oxide Contribution (\%) (in SME) & $0.0 \%$ & $26.0 \%$ & $74.0 \%$ & 15399.2 & "kg Calc. Basis \\
\hline Density $(\mathrm{kg} / \mathrm{L})$ & 1.0355 & 1.130 & $n / a$ & $137.0 \%$ & \\
\hline Total Solids (\%) & $5.38 \%$ & $19.88 \%$ & $n / a$ & $48.0 \%$ & \\
\hline Calcine Factor (ox/sol) & 1.00 & 0.78 & $n / a$ & $n / a$ & \\
\hline Hydroxide (M) & $n / a$ & 0.646 & $n / a$ & $n / a$ & . \\
\hline Mercury (ppm) & $n / a$ & 2584.4 & $n / a$ & na & \\
\hline Total Mn (wt\% solids) & $n / a$ & 4.45 & $n / a$ & $n / a$ & . \\
\hline Soluble Mn (ppm) & $n / a$ & 0.00 & $n / a$ & $n / a$ & \\
\hline *TIC (ppm) & n'a & 0.00 & na & $n / a$ & \\
\hline Total Acid (M) & 0.240 & $n / a$ & $n / a$ & $n / a$ & - \\
\hline Nitrite (ppm) & 0.0 & 8452.0 & $0.0(\mathrm{~kg} / 100 \mathrm{~kg}$ frit $)$ & & \\
\hline NO2 Destruction & $0.0 \%$ & $100.0 \%$ & $0.0 \%$ & & \\
\hline Nitrate (ppm) & 1012.1 & 3466.0 & $0.0(\mathrm{~kg} / 100 \mathrm{~kg}$ frit $)$ & & \\
\hline$\%$ nitrite to nitrate conversion & & $35.0 \%$ & & & \\
\hline Formate (ppm) & 22808.9 & 0.0 & $1.0(\mathrm{~kg} / 100 \mathrm{~kg}$ frit) & & \\
\hline Reaction formate destruction, $\mathrm{kg}$ & & 142.37 & & & \\
\hline Factor for total formate destruction & & $15.0 \%$ & & & \\
\hline Total formate destruction, $\mathrm{kg}$ & & 21.36 & & & \\
\hline Oxide Mass (kg) & 0.0 & 4003.8 & 11395.4 & 15399.2 & \\
\hline Solids Mass (kg) & 0.00 & 5102.26 & 11395.39 & 16497.65 & \\
\hline Total Mass (kg) & 0.00 & 25665.29 & $n / a$ & 34370.10 & \\
\hline Volume (L) & 0.00 & $22,712.65$ & $n / a$ & 25087.67 & \\
\hline$\%$ Stoichiometry & $n / a$ & $125.0 \%$ & n'a & $n / a$ & \\
\hline Volume HNO3@50\% (L) & $n / a$ & 2.839 .60 & $n^{\prime} a$ & $n / a$ & \\
\hline NO2 Contribution (kg) & 0.000 & 216.923 & 0.000 & 216.923 & \\
\hline NO2 Remaining (kg) & 0.000 & 0.000 & 0.000 & 0.000 & - \\
\hline NO3 Contribution (kg) & 0.000 & 1987.098 & 0.000 & 1987.098 & \\
\hline $\mathrm{COOH}$ Contribution (kg) & 0.000 & $(142.37)$ & 93.843 & $(48) .530$ & \\
\hline NO2 (Molar@45\%) & & & & 0.000 & \\
\hline NO3 (Molar@45\%) & & & & 1.359 & \\
\hline COOH (Molar@45\%) & & & & -0.046 & \\
\hline Predicted $\mathrm{Fe}(\mathrm{II}) / \mathrm{LFe}$ & & & 0.09 & BDL@0.03 & $\leq 0.1$ \\
\hline Volume HCOOH@90\% (L) & & & 3458.10 & 3180.09 & 3504.50 \\
\hline$\%$ Stoichiometry & $n / a$ & $125.0 \%$ & $n / a$ & $n / a$ & \\
\hline Volume HCOOH@90\% (L) & $n / a$ & $1,247.85$ & $n / a$ & $n / a$ & \\
\hline NO2 Contribution (kg) & 0.000 & 216.923 & 0.000 & 216.923 & \\
\hline NO2 Remaining (kg) & 0.000 & 0.000 & 0.000 & 0.000 & \\
\hline NO3 Contribution (kg) & 0.000 & 164.879 & 0.000 & 164.879 & \\
\hline $\mathrm{COOH}$ Contribution (kg) & 0.000 & 1301.639 & 93.843 & 1395.482 & \\
\hline NO2 (Molar@45\%) & & & & 0.000 & \\
\hline NO3 (Molar@45\%) & & & & 0.113 & \\
\hline COOH (Molar@45\%) & & & & 1.314 & \\
\hline Predicted $\mathrm{Fe}(\mathrm{II}) / \Sigma \mathrm{Fe}$ & & & 0.09 & 0.470 & $\leq 0.1$ \\
\hline Volume HNO3@50\% (L) & & & 1230.65 & & 1195.51 \\
\hline
\end{tabular}

${ }^{\top}$ Value in parentheses represents corrected value due to scale factor error. 
Weștinghouse Savannah River Company Savannah River Technology Center
APPENDIX A-2: Heel Prep 2
WSRC-TR-99-00111, Rev. 0

Page 40 of 111

Table XXII. Large Batch SRAT Heel Preparation Redox Calculation Continued

mol\% Nitric
Volume HCOOH@90\%(L)
Volume HNO3@50\% (L)
NO2 Contribution (kg)
NO2 Remaining (kg)
NO3 Contribution (kg)
COOH Contribution (kg)
NO2 (Molar@45\%)
NO3 (Molar@45\%)
COOH (Molar@45\%)
Predicted Fe(II)/5Fe

\begin{tabular}{|rrr}
$n / a$ & $17.9 \%$ & $n / a$ \\
$n / a$ & $1,024.48$ & $n / a$ \\
& 508.29 & \\
& 216.923 & 0.000 \\
0.000 & 0.000 & 0.000 \\
0.000 & 491.056 & 0.000 \\
0.000 & 943.805 & 0.000 \\
0.000 & & \\
& & 0.09
\end{tabular}

$n / a$

$n / a$

216.923

0.000

491.056

943.805

0.000

0.336

0.889

${ }^{\dagger}$ Value in parentheses represents corrected value due to scale factor error.

kgb 9/16/96 
Weștinghouse Savannah River Company Savannah River Technology Center
WSRC-TR-99-00111, Rev. 0

Page 41 of 111

Date: 6-15-99

Run \# LBH2

\section{PREREQUISITES}

1. Signed TAR requesting work.

2. Issued Testing scope and task assignment.

3. Analyze sludge for density, total base (pH 5.5), nitrate, manganese, nitrite, density, solids.

4. Calibrate GC. Calibrate for nitrogen, oxygen, N2O, hydrogen, and carbon dioxide.

5. Mrepare sufficient $90 \%$ formic acid and $50 \%$ nitric acid.

6. Prepare sufficient antifoam solution or make sure sufficient solution is available.

7. Calculate batching and scaling for experiment based on DWPF parameters.

8. Calculate redox for experiment based on DWPF parameters.

9. Setup experimental rig per sketch below.

10. U Complete leak check and water run.

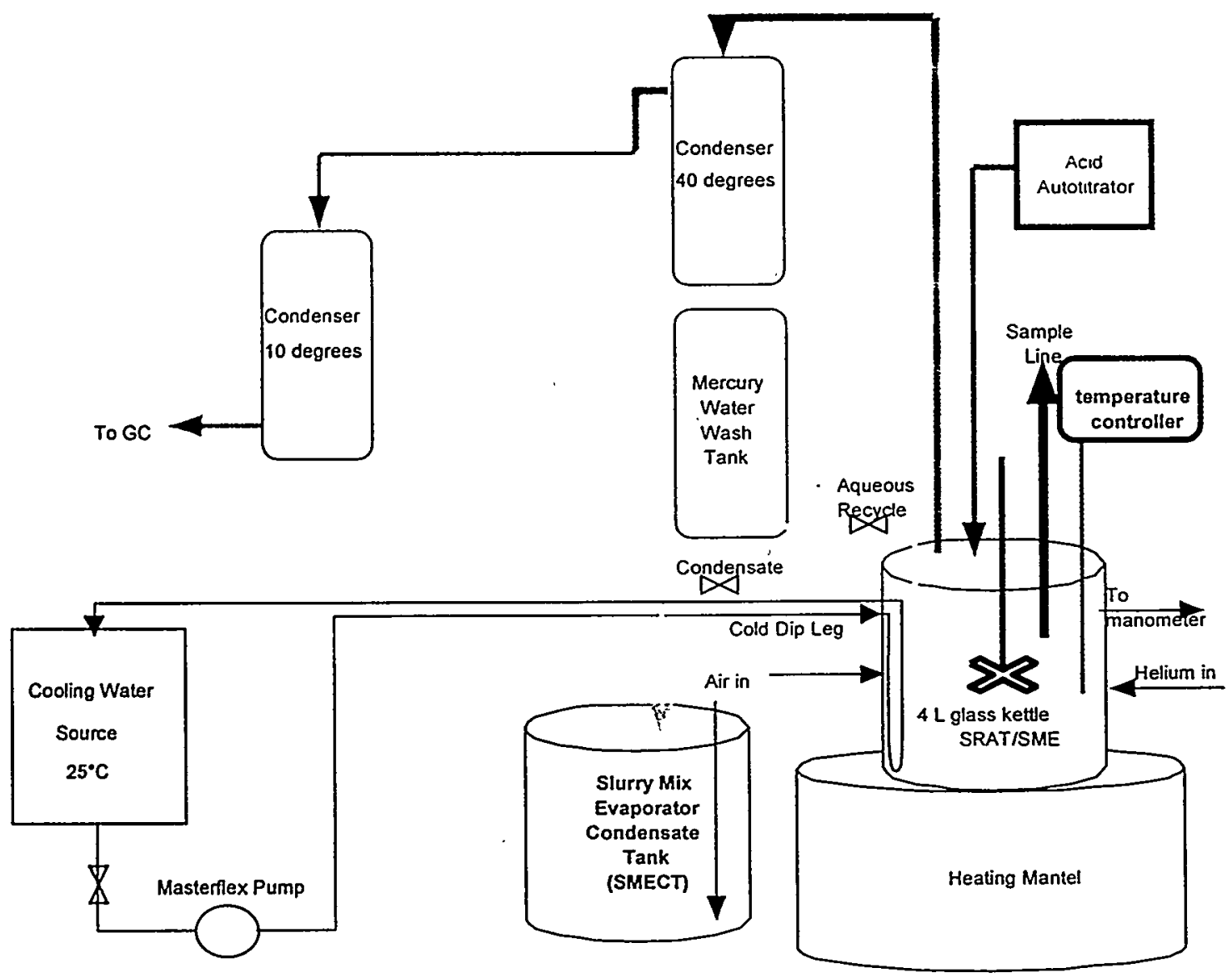


Westinghouse Savannah River Company

Savannah River Technology Center

Run \# _ LBH2
APPENDIX A-2: Heel Prep 2

WSRC-TR-99-00111, Rev. 0

Page 42 of 111

Date: 6-15-99

\section{PREPARATION FOR SRAT CYCLE}

Note: Do not insulate kettle until acid addition is complete

1. Add $2100 \mathrm{~g}$ of Sludge $\mathrm{A}^{\prime}$ to kettle.

2. Turn on kettle agitator. Setpoint $=\mathbf{2 0 0} \mathrm{rpm}$. Mark Sludge. Level in Kettle as De-water Level for later dewatering and concentration.

3. Turn on cooling water to SRAT condenser. Setpoint $=40^{\circ} \mathrm{C}$.

4. Turn on cooling water to Chilled (FAVC) condenser. Setpoint $=10^{\circ} \mathrm{C}$.

5. Add trim chemicals (from ) directly to the kettle.

6. Transfer $309.7 \mathrm{~g}$ of distilled water to the kettle (use to rinse all containers used for adding sludge, noble metals, mercury, etc.).

7. Calibrate $\mathrm{pH}$ probe with $\mathrm{pH} 4$ and 10 buffer. Record measured $\mathrm{pH}$ of $\mathrm{pH} 7$ buffer 7.131 .

8. Install pH probe in kettle. Record initial pH of sludge _ 12.068 .

9. Turn on the air purge to kettle at $\mathbf{1 0 0 . 0}$ sccm. Connect the outlet flowmeter to perform the leak check. The outlet flow should be $\mathbf{9 0 - 1 1 0 ~} \mathbf{s c c m}$. If it is not, tighten all connections until the system is leak tight. Write flown the leak check in the logbook.

10. Disconnect outlet flowmeter.

11. Set the air flow to kettle at $490 \mathrm{sccm}$. Set the He flow to $2.46 \mathrm{sccm}$.

12. Make sure the GC computer has enough memory space for the run (at least 40 Mbyte).

13. Set the GC computer time equal to the clock time. Record the time in the log book.

14. Install the calibration gas cylinder to the GC and let the GC run five times. If at the end of five runs the GC reading is within $10 \%$ of the gas composition in the cylinder, print the calibration check results and write down "pre-cal check and run number" on the printout. Otherwise, select "Calibration" "Level 1" "OK" to calibrate the GC five times. At the end of five runs the GC reading should be within $10 \%$ of the gas composition in the cylinder. If it is not, contact the engineer. Print the calibration check results and write down "pre-cal check and run number" on the printout.

15. Start the GC for this run beginning with baseline reading for a few minutes. Write down the GC time, filename etc. in the logbook. Record the baseline data on the data sheet. 
Weștinghouse Savannah River Company

Savannah River Technology Center

Run \# LBH2
APPENDIX A-2: Heel Prep 2

WSRC-TR-99-00111, Rev. 0

Page 43 of 111

Date:

\section{SRAT CYCLE}

1. Add $2.1 \mathrm{~g}$ 1:10 antifoam solution and $2.1 \mathrm{~g}$ water directly to the kettle (100 ppm antifoam).

2. Start heating up the kettle with the TEMP-O-TROL Model TOT-VOVC (yellow box) temperature controller. l'urn on its power switch, turn the voltage output dial to maximum (115), press and hold the up $[\Delta]$ and down $[\nabla]$ keys simultaneously until display flashes between TUNE and OFF, then press the up $[\Delta]$ key until display says SPrr, now press and hold the enter $\left[{ }^{*}\right]$ key and the display should show 60 for ${ }^{\circ} \mathrm{C}$ per hour the system will ramp up to reach its setpoint. If the display shows something other than 60 then while pressing the enter $\left[^{*}\right]$ key, press the up or down keys to adjust the value to 60 . To return to the normal temperature display, press and hold up $[\Delta]$ and down $[\nabla]$ keys simultaneously until the temperature is shown. Now press and hold the enter $\left[{ }^{*}\right]$ key to check the current setpoint which should be 93 . If the display shows something other than 93 then while pressing the enter [*] key, press the up or down keys to adjust the value to 93 . Once you release the enter [*] key, a little flashing block [ $\square]$ should appear in the upper left corner of the display and the ON light should illuminate indicating power to the heating mantle. The temperature should ramp to $93^{\circ} \mathrm{C}$ then hold there. Record the run data every 20 minutes on the data sheet.

3. If slurry begins to foam over at any time, switch off heating and turn on the cooling coil water pump to bring the temperature down rapidly. Add antifoam solution as shown in Step 1. Then switch off the cooling coil water pump and slowly heat up the kettle again to the point of boiling.

4. Once at $93^{\circ} \mathrm{C}$, add $46.77 \mathrm{ml}$ of $50-w t \%$ nitric acid at $0.697 \mathrm{ml} / \mathrm{min}$ (reference Table XXI) to the kettle. Should take about 1.1 hour.

5. Now add $104.74 \mathrm{ml}$ of $90-w \mathrm{t} \%$ formic acid at $0.700 \mathrm{ml} / \mathrm{min}$ (reference Table XXI) to the kettle. Should take about 2.3 hours.

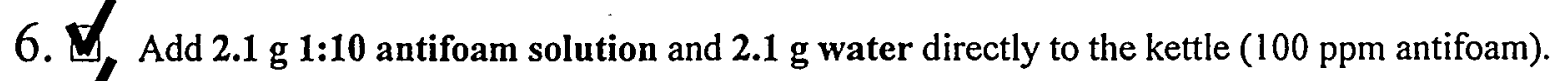

7. Adjust the setpoint on the TEMP-O-TROL to $110^{\circ} \mathrm{C}$ by pressing and holding the enter [*] key and pressing the up $[\Delta]$ and down $[\nabla]$ keys. Adjust voltage output to $3.5 \mathrm{~g} / \mathrm{min}$ boil-up rate and bring the kettle contents to boiling.

8. Dewater until remove $469.6 \mathrm{~g}$ of water in the SMECT leaving approximately $2 \mathrm{~L}$ in the kettle (kettle volume should be close to De-water Level marked in Step 2 of PREPARATION FOR SRAT CYCLE). Should take about 2.2 hours.

9. Reflux the slurry for a total of 13 hours (including the dewater times in step 8 ) at $3.5 \mathrm{~g} / \mathrm{min}$ boilup. Continue refluxing until there is evidence of nitrite destruction (hydrogen release) and the hydrogen has reached its peak. Then turn off the heat to cool the kettle to sub-boiling.

10. Vull a $125 \mathrm{ml}$ sample (LB SRAT Heel 2) from the kettle, record the weight here 121.0 . Label and send to lab for analyses.

11. After vessel has cooled, hook up pump to remove a set amount of SRAT product in preparation of the large batch run. 
Westinghouse Savannah River Company

Savannah River Technology Center
APPENDIX A-3: Runs 2V/3V

WSRC-TR-99-00111; Rev. 0

Page 44 of 111

\section{APPENDIX A-3: LARGE BATCH RUNS 2V \& 3V}

SRT-PTD-98-0039, Rev. 1

CC: E. W. Holtzscheiter, 773-A

J. E. Occhipinti, 704-27S

S. L. Marra, 704-25S

R. E. Edwards, 704-25S

R. E. Eibling, 704-1T

P. R. Monson, 704-1T

D. P. Lambert, 704-1T

M. F. Williams, 704-1T

J. W. Duvall, 704-1T

M. L. Johnson, 772-T

S. O. King, 677-T

V. J. Williams, 677-T

D. C. Koopman, 704-T

January 7, 1999

TO: $\quad$ L. F. Landon, 704-1T

FROM: W. E. Daniel, 704-1T

\section{Run Plan for Large Batch Variability Runs with Normal Weight\% Solids Sludge for Developing Strategies for Increased CPC Batch Sizes (U)}

This run plan documents the variability runs with normal weight percent solids sludge as detailed in the Task Technical Plan for Developing Strategy for Increased CPC Batch Size (WSRC-RP-98-00354) as requested in DWPF Technical Task Request HLW/DWPT/TTR-980013. The experimental work will be controlled using the Laboratory Scale Chemical Process Cell Simulations (Manual L27, Procedure 2.02) and this run plan. This run plan includes many of the experimental details, the instructions for final sludge preparation, the scaling necessary for determining the operating conditions such as feed rates, purge rates, and the steps in completing the SRAT and SME cycles. This document also summarizes the decisions made to complete these experiments.

1) The sludge used for the SRAT Heel preparation is a Tank 42-sludge simulant created from the Optima Tank 51 simulant with the following modifications.

a) A recipe is shown in Table XXIII that targets a 20 weight percent solids sludge after the trim chemicals (noble metals and mercury) are added. This sludge will be referred to as Sludge $A^{\prime}$ and its pre-trim measured as well as post-trim predicted elemental weight percent analyses are shown in Table XXIV. Analyses of the SRAT Heel used in these experiments are shown in Table XXV.

b) Tank 42 levels of noble metals and mercury will be added to the sludge batches as shown in Table XXVI and Table XXX. These levels will require approximately 14 hours of refluxing in the SRAT to steam strip mercury and meet the DWPF constraint of $0.45 \mathrm{wt} \%$ mercury. 
WSRC-TR-99-00111, Rev. 0

Page 45 of 111

Table XXIII. Preparation Of Tank 42 Sludge 20 weight \% (Trim Chemicals Missing)

\begin{tabular}{|c|c|c|}
\hline Component & Amount, $g$ & Comments \\
\hline Tank 51 sludge simulant & 16521.36 & 18.52 wt\% solids initially \\
\hline Tank 51 supernate & 527.2 & Added Supernate to lower wt\% solids \\
\hline $\mathrm{Al}_{2} \mathrm{O}_{3}$ & 148.29 & \\
\hline $\mathrm{Ni}\left(\mathrm{NO}_{3}\right)_{2} * 6 \mathrm{H}_{2} \mathrm{O}$ & 30.22 & \\
\hline $\mathrm{SiO}_{2}$ & 53.48 & \\
\hline $\mathrm{MnO}_{2}{ }^{*} \mathrm{H}_{2} \mathrm{O}$ & 221.77 & Total Mass @ 27.2 wt\% solids \\
\hline $\mathrm{Water}_{\mathrm{Al}_{2} \mathrm{O}_{3}}$ & 200.00 & \\
\hline $\mathrm{Na}_{2} \mathrm{C}_{2} \mathrm{O}_{4}$ & 0.94 & \\
\hline $\mathrm{NaF}$ & 4.87 & \\
\hline $\mathrm{NaOH}$ & 0.66 & \\
\hline $\mathrm{NaCl}$ & 7.05 & \\
\hline & 0.82 & \\
\hline
\end{tabular}

Table XXIV. Elemental Analyses of Large Batch $20 \mathrm{wt} \%$ Sludge $\mathrm{A}^{\prime}$

\begin{tabular}{|c|c|c|c|c|c|}
\hline $\begin{array}{c}\text { Insoluble } \\
\text { Species }\end{array}$ & $\begin{array}{c}\text { Measured } \\
\text { Wt\% Solids } \\
\text { Pre-Trim }\end{array}$ & $\begin{array}{c}\text { Predicted Wt } \\
\text { Solids Post- } \\
\text { Trim }\end{array}$ & $\begin{array}{c}\text { Soluble } \\
\text { Species }\end{array}$ & $\begin{array}{c}\text { Measured } \\
\text { Wt\% Solids } \\
\text { Pre-Trim }\end{array}$ & $\begin{array}{c}\text { Predicted } \\
\text { Wt\% } \\
\text { Solids Post- } \\
\text { Trim }\end{array}$ \\
\hline $\mathrm{Al}$ & $5.72 \%$ & $7.58 \%$ & $\mathrm{Al}$ & & $0.02 \%$ \\
\hline${ }^{*} \mathrm{Ag}$ & & $0.04 \%$ & $\mathrm{C} 2 \mathrm{O} 4$ & $0.28 \%$ & $0.27 \%$ \\
\hline $\mathrm{Ca}$ & $2.04 \%$ & $1.94 \%$ & $\mathrm{Cl}$ & $0.04 \%$ & $0.04 \%$ \\
\hline${ }^{*} \mathrm{Cd}$ & & $0.11 \%$ & $\mathrm{CO} 3$ & & $1.81 \%$ \\
\hline $\mathrm{Cl}$ & & $0.07 \%$ & $\mathrm{Cr}$ & & $0.00 \%$ \\
\hline $\mathrm{Cr}$ & & $0.16 \%$ & $\mathrm{~F}$ & $0.01 \%$ & $0.02 \%$ \\
\hline $\mathrm{Cu}$ & $0.02 \%$ & $0.02 \%$ & $\mathrm{~K}$ & & $0.00 \%$ \\
\hline $\mathrm{F}$ & & $0.01 \%$ & $\mathrm{Li}$ & & $0.00 \%$ \\
\hline $\mathrm{Fe}$ & $23.08 \%$ & $21.80 \%$ & $\mathrm{Na}$ & & $0.25 \%$ \\
\hline${ }^{*} \mathrm{Hg}$ & & $1.30 \%$ & $\mathrm{NO} 2$ & $4.38 \%$ & $3.73 \%$ \\
\hline $\mathrm{K}$ & $0.16 \%$ & $0.05 \%$ & $\mathrm{NO} 3$ & $1.80 \%$ & $1.44 \%$ \\
\hline $\mathrm{Li}$ & $0.00 \%$ & $0.00 \%$ & $\mathrm{OH}$ & & $0.12 \%$ \\
\hline $\mathrm{Mg}$ & $1.13 \%$ & $1.11 \%$ & $\mathrm{PO} 4$ & $0.06 \%$ & $0.05 \%$ \\
\hline $\mathrm{Mn}$ & $4.48 \%$ & $3.64 \%$ & $\mathrm{SO} 4$ & $0.26 \%$ & $0.21 \%$ \\
\hline $\mathrm{Na}$ & $7.88 \%$ & $5.74 \%$ & & & \\
\hline $\mathrm{Ni}$ & $0.35 \%$ & $0.34 \%$ & & & \\
\hline $\mathrm{P}$ & & $0.00 \%$ & & & \\
\hline${ }^{*} \mathrm{Pd}$ & & $0.00 \%$ & & & \\
\hline $\mathrm{Pu}$ & & $0.00 \%$ & & & \\
\hline${ }^{\mathrm{Rh}}$ & & $0.01 \%$ & & & \\
\hline${ }^{*} \mathrm{Ru}$ & & $0.02 \%$ & & & \\
\hline $\mathrm{Se}$ & & $0.00 \%$ & & & \\
\hline $\mathrm{Si}$ & $1.64 \%$ & $1.80 \%$ & & & \\
\hline $\mathrm{Te}$ & & $0.00 \%$ & & & \\
\hline $\mathrm{Ti}$ & $0.05 \%$ & $0.05 \%$ & & & \\
\hline $\mathrm{U}$ & & $0.00 \%$ & & & \\
\hline $\mathrm{Zn}$ & $0.01 \%$ & 0.00 & & & \\
\hline & & & & & \\
\hline & & & & \\
\hline
\end{tabular}


Westinghouse Savannah River Company

Savannah River Technology Center
APPENDIX A-3: Runs 2V/3V

WSRC-TR-99-00111, Rev. 0

Page 46 of 111

Table XXV. Elemental Analyses of Large Batch 20.4 wt\% SRAT Heel prepared from Sludge A'

\begin{tabular}{|c|c|c|c|}
\hline $\begin{array}{l}\text { Insoluble } \\
\text { Species }\end{array}$ & $\begin{array}{c}\text { Measured } \\
\text { Wt\% Solids }\end{array}$ & $\begin{array}{l}\text { Soluble } \\
\text { Species }\end{array}$ & $\begin{array}{l}\text { Measured } \\
\text { Wt\% Solids }\end{array}$ \\
\hline $\mathrm{Al}$ & $5.30 \%$ & $\mathrm{Al}$ & -- \\
\hline$* A g$ & -- & $\mathrm{C} 2 \mathrm{O} 4$ & $0.04 \%$ \\
\hline $\mathrm{Ca}$ & $2.04 \%$ & $\mathrm{Cl}$ & $0.16 \%$ \\
\hline${ }^{*} \mathrm{Cd}$ & $0.00 \%$ & $\mathrm{CO} 3$ & - \\
\hline $\mathrm{Cl}$ & -- & $\mathrm{Cr}$ & -- \\
\hline $\mathrm{Cr}$ & -- & $F$ & - \\
\hline $\mathrm{Cu}$ & $0.01 \%$ & $\mathrm{~K}$ & -- \\
\hline$F$ &.- & $\mathrm{Li}$ & -- \\
\hline $\mathrm{Fe}$ & $.20 .80 \%$ & $\overline{\mathrm{Na}}$ & - \\
\hline${ }^{*} \mathrm{Hg}$ & -- & $\mathrm{NO} 2$ & $0.12 \%$ \\
\hline $\mathrm{K}$ & $0.14 \%$ & NO3 & $9.07 \%$ \\
\hline$\overline{\mathrm{Li}}$ & $0.00 \%$ & $\mathrm{OH}$ & -- \\
\hline $\mathrm{Mg}$ & $0.89 \%$ & PO4 & $0.04 \%$ \\
\hline $\mathrm{Mn}$ & $4.17 \%$ & SO4 & $0.10 \%$ \\
\hline $\mathrm{Na}$ & $7.26 \%$ & & . \\
\hline $\mathrm{Ni}$ & $0.32 \%$ & & \\
\hline $\mathrm{P}$ & $0.24 \%$ & & \\
\hline *Pd & $0.045 \%$ & & \\
\hline $\mathrm{Pu}$ & -- & & \\
\hline${ }^{*} \mathrm{Rh}$ & $0.0053 \%$ & & \\
\hline *Ru & $0.032 \%$ & & \\
\hline $\mathrm{Se}$ & -- & & \\
\hline $\mathrm{Si}$ & $1.17 \%$ & & \\
\hline $\mathrm{Te}$ & $0.00 \%$ & & \\
\hline$\overline{\mathrm{Ti}}$ & $0.03 \%$ & $\div$ & \\
\hline $\mathrm{U}$ & -- & & \\
\hline $\mathrm{Zn}$ & $0.11 \%$ & & \\
\hline
\end{tabular}


Table XXVI. Trim Chemical Addition for First Sludge Addition for Run 2V

\begin{tabular}{|c|c|c|c|c|c|}
\hline & $\begin{array}{c}\text { Target } \\
\text { Addition, } \mathrm{g}\end{array}$ & $\begin{array}{c}\text { Actual } \\
\text { Addition, } \mathrm{g}\end{array}$ & Wt\% Solids & Target Solids, g & $\begin{array}{l}\text { Actual Solids } \\
\text { added, } \mathrm{g}\end{array}$ \\
\hline S' & $2 n n n g n$ & $20 n n n$ & $\ln : \%$ & 386.0 & $306 n$ \\
\hline Trim Chemicals & $\begin{array}{c}\text { Target } \\
\text { Addition, grams }\end{array}$ & $\begin{array}{l}\text { Actual } \\
\text { Addition, } \\
\text { grams }\end{array}$ & $\begin{array}{l}\text { Elemental Solids } \\
\text { Factor }\end{array}$ & $\begin{array}{l}\text { Target Elemental } \\
\text { Solids, } g\end{array}$ & $\begin{array}{l}\text { Actual Elemental } \\
\text { Solids, } \mathrm{g}\end{array}$ \\
\hline AgNO3 & 0.225 & 0.2252 & 0.6349 & 0.143 & 0.143 \\
\hline $\mathrm{Cd}(\mathrm{NO} 3) 2 * 4 \mathrm{H} 2 \mathrm{O}$ & 1.165 & 1.1646 & 0.3644 & 0.425 & 0.424 \\
\hline $\mathrm{HgO}$ & 5.126 & 5.125 & 0.9261 & 4.748 & 4.746 \\
\hline $\mathrm{Pd}(\mathrm{NO} 3) 2^{*} \mathrm{H} 2 \mathrm{O}$ & 0.020 & 0.021 & $0.1527^{\dagger}$ & 0.008 & $0.003^{\dagger}$ \\
\hline $\mathrm{Rh}(\mathrm{NO} 3)^{3 *} 2 \mathrm{H} 2 \mathrm{O}$ & 0.065 & 0.064 & $0.0493^{\dagger}$ & 0.020 & $0.003^{T}$ \\
\hline $\mathrm{RuCl3}$ & 0.174 & 0.174 & $0.4174^{\dagger}$ & 0.085 & $0.073^{\top}$ \\
\hline
\end{tabular}

\begin{tabular}{|c|c|c|}
\hline Element & $\begin{array}{c}\text { Target Wt\% } \\
\text { Solids }\end{array}$ & $\begin{array}{c}\text { Actual Wt\% } \\
\text { Solids }\end{array}$ \\
\hline $\mathrm{Ag}$ & $0.04 \%$ & $0.04 \%$ \\
\hline $\mathrm{Cd}$ & $0.11 \%$ & $0.11 \%$ \\
\hline $\mathrm{Hg}$ & $1.30 \%$ & $1.23 \%$ \\
\hline $\mathrm{Pd}$ & $0.0022 \%$ & $0.0008 \%$ \\
\hline $\mathrm{Rh}$ & $0.0053 \%$ & $0.0008 \%$ \\
\hline $\mathrm{Ru}$ & $0.022 \%$ & $0.019 \%^{\dagger}$ \\
\hline
\end{tabular}

$\dagger$ Values changed from original run plan to reflect noble metal under addition.

Table XXVII. Trim Chemical Addition for Second Sludge Addition for Run 2V

\begin{tabular}{|c|c|c|c|c|c|}
\hline & $\begin{array}{c}\text { Target } \\
\text { Addition, } \mathrm{g}\end{array}$ & $\begin{array}{c}\text { Actual } \\
\text { Addition, } \mathrm{g}\end{array}$ & Wt\% Solids & Target Solids, $\mathrm{g}$ & $\begin{array}{l}\text { Actual Solids } \\
\text { added, g }\end{array}$ \\
\hline Sludge $A^{\prime}$ & 333.3 & 333.3 & $19.3 \%$ & 64.3 & 64.3 \\
\hline Trim Chemicals & $\begin{array}{c}\text { Target } \\
\text { Addition, grams }\end{array}$ & $\begin{array}{c}\text { Actual } \\
\text { Addition, } \\
\text { grams }\end{array}$ & $\begin{array}{l}\text { Elemental Solids } \\
\text { Factor }\end{array}$ & $\begin{array}{l}\text { Target Elemental } \\
\text { Solids, } \mathrm{g}\end{array}$ & $\begin{array}{l}\text { Actual Elemental } \\
\text { Solids, } \mathrm{g}\end{array}$ \\
\hline AgNO3 & 0.037 & 0.0373 & 0.6349 & 0.024 & 0.024 \\
\hline $\mathrm{Cd}(\mathrm{NO} 3) 2 * 4 \mathrm{H} 2 \mathrm{O}$ & 0.194 & 0.194 & 0.3644 & 0.070 & 0.070 \\
\hline HgO & 0.903 & 0.904 & 0.9261 & 0.836 & 0.837 \\
\hline $\mathrm{Pd}(\mathrm{NO3}) 2^{*} \mathrm{H} 2 \mathrm{O}$ & 0.003 & 0.003 & $0.1527^{\dagger}$ & 0.002 & 0.002 \\
\hline $\mathrm{Rh}(\mathrm{NO3}) 3^{*} 2 \mathrm{H} 2 \mathrm{O}$ & 0.010 & 0.010 & $0.0493^{\dagger}$ & 0.004 & 0.004 \\
\hline $\mathrm{RuCl3}$ & 0.029 & 0.029 & $0.4174^{f}$ & 0.014 & 0.014 \\
\hline
\end{tabular}

\begin{tabular}{|c|c|c|}
\hline Element & $\begin{array}{c}\text { Target Wt\% } \\
\text { Solids }\end{array}$ & $\begin{array}{c}\text { Actual Wt\% } \\
\text { Solids }\end{array}$ \\
\hline $\mathrm{Ag}$ & $0.04 \%$ & $0.04 \%$ \\
\hline $\mathrm{Cd}$ & $0.11 \%$ & $0.11 \%$ \\
\hline $\mathrm{Hg}$ & $1.30 \%$ & $1.30 \%$ \\
\hline $\mathrm{Pd}$ & $0.0022 \%$ & $0.0007 \%^{\dagger}$ \\
\hline $\mathrm{Rh}$ & $0.0053 \%$ & $0.0008 \%^{\dagger}$ \\
\hline $\mathrm{Ru}$ & $0.022 \%$ & $0.019 \%^{\dagger}$ \\
\hline
\end{tabular}

†Values changed from original run plan to reflect noble metal under addition. 
Westinghouse Savannah River Company

Savannah River Technology Center
APPENDIX A-3: Runs 2V/3V WSRC-TR-99-00111, Rev. 0

Page 48 of 111

Table XXVIII. Trim Chemical Addition for First Sludge Addition for Run 3V

\begin{tabular}{|c|c|c|c|c|c|}
\hline & $\begin{array}{c}\text { Target } \\
\text { Addition, } g\end{array}$ & $\begin{array}{c}\text { Actual } \\
\text { Addition, } g\end{array}$ & Wt\% Solids & Target Solids, g & $\begin{array}{c}\text { Actual Solids } \\
\text { added, },\end{array}$ \\
\hline Sludge $A^{\prime}$ & 2000.0 & 2000.0 & $19.3 \%$ & 386.0 & 386.0 \\
\hline Trim Chemicals & $\begin{array}{c}\text { Target } \\
\text { Addition, grams }\end{array}$ & $\begin{array}{c}\text { Actuai } \\
\text { Addition, } \\
\text { grams }\end{array}$ & $\begin{array}{c}\text { Elemental } \\
\text { Solids Factor }\end{array}$ & $\begin{array}{c}\text { Target Elemental } \\
\text { Solids, } g\end{array}$ & $\begin{array}{c}\text { Actual Elemental } \\
\text { Solids, } g\end{array}$ \\
\hline AgNO3 & 0.225 & 0.225 & 0.6349 & 0.143 & 0.143 \\
\hline Cd(NO3)2*4H2O & $\mathbf{1 . 1 6 5}$ & 1.164 & 0.3644 & 0.425 & 0.424 \\
\hline HgO & $\mathbf{5 . 1 6 8}$ & 5.168 & 0.9261 & 4.786 & 4.786 \\
\hline Pd(NO3)2*H2O & $\mathbf{0 . 0 2 0}$ & 0.022 & $0.1527^{\dagger}$ & 0.008 & $0.003^{\dagger}$ \\
\hline Rh(NO3)3*2H2O & $\mathbf{0 . 0 6 5}$ & 0.065 & $0.0493^{\dagger}$ & 0.020 & $0.003^{\dagger}$ \\
\hline RuCl3 & $\mathbf{0 . 1 7 4}$ & 0.174 & $0.4174^{\dagger}$ & 0.085 & $0.073^{\dagger}$ \\
\hline
\end{tabular}

\begin{tabular}{|c|c|c|}
\hline Element & $\begin{array}{c}\text { Target Wt\% } \\
\text { Solids }\end{array}$ & $\begin{array}{c}\text { Actual Wt\% } \\
\text { Solids }\end{array}$ \\
\hline $\mathrm{Ag}$ & $0.04 \%$ & $0.04 \%$ \\
\hline $\mathrm{Cd}$ & $0.11 \%$ & $0.11 \%$ \\
\hline $\mathrm{Hg}$ & $1.30 \%$ & $1.30 \%$ \\
\hline $\mathrm{Pd}$ & $0.0022 \%$ & $0.0009 \%^{\dagger}$ \\
\hline $\mathrm{Rh}$ & $0.0053 \%$ & $0.0008 \%$ \\
\hline $\mathrm{Ru}$ & $0.022 \%$ & $0.019 \%$ \\
\hline
\end{tabular}

${ }^{f}$ Values changed from original run plan to reflect noble metal under addition.

Table XXIX. Trim Chemical Addition for Second Sludge Addition for Run 3V

\begin{tabular}{|c|c|c|c|c|c|}
\hline & $\begin{array}{c}\text { Target } \\
\text { Addition, } \mathrm{g}\end{array}$ & $\begin{array}{c}\text { Actual } \\
\text { Addition, } \mathrm{g}\end{array}$ & Wt\% Solids & Target Solids, $\mathrm{g}$ & $\begin{array}{c}\text { Actual Solids } \\
\text { added, } \mathrm{g}\end{array}$ \\
\hline Sludge $A^{\prime}$ & 333.3 & 333.3 & $19.3 \%$ & 64.3 & 64.3 \\
\hline Trim Chemicals & $\begin{array}{c}\text { Target } \\
\text { Addition, grams }\end{array}$ & $\begin{array}{c}\text { Actual } \\
\text { Addition, } \\
\text { grams }\end{array}$ & $\begin{array}{c}\text { Elemental } \\
\text { Solids Factor }\end{array}$ & $\begin{array}{c}\text { Target Elemental } \\
\text { Solids, } \mathrm{g}\end{array}$ & $\begin{array}{c}\text { Actual Elemental } \\
\text { Solids, } \mathrm{g}\end{array}$ \\
\hline AgNO3 & $\mathbf{0 . 0 3 7}$ & 0.038 & 0.6349 & 0.024 & 0.024 \\
\hline Cd(NO3)2 4 H2O & $\mathbf{0 . 1 9 4}$ & 0.194 & 0.3644 & 0.070 & 0.070 \\
\hline HgO & $\mathbf{0 . 9 1 0}$ & 0.907 & 0.9261 & 0.843 & 0.840 \\
\hline Pd(NO3)2*H2O & 0.003 & 0.004 & $0.1527^{\dagger}$ & 0.002 & $0.0006^{\dagger}$ \\
\hline Rh(NO3)3*2H2O & $\mathbf{0 . 0 1 0}$ & 0.0105 & $0.0493^{\dagger}$ & 0.004 & $0.0005^{\dagger}$ \\
\hline RuCl3 & $\mathbf{0 . 0 2 9}$ & 0.031 & $0.4174^{\dagger}$ & 0.014 & $0.013^{\dagger}$ \\
\hline
\end{tabular}

\begin{tabular}{|c|c|c|}
\hline Element & $\begin{array}{c}\text { Target Wt\% } \\
\text { Solids }\end{array}$ & $\begin{array}{c}\text { Actual Wt\% } \\
\text { Solids }\end{array}$ \\
\hline $\mathrm{Ag}$ & $0.04 \%$ & $0.04 \%$ \\
\hline $\mathrm{Cd}$ & $0.11 \%$ & $0.11 \%$ \\
\hline $\mathrm{Hg}$ & $1.30 \%$ & $1.31 \%$ \\
\hline $\mathrm{Pd}$ & $0.0022 \%$ & $0.0001 \%{ }^{\dagger}$ \\
\hline $\mathrm{Rh}$ & $0.0053 \%$ & $0.0008 \%{ }^{\dagger}$ \\
\hline $\mathrm{Ru}$ & $0.022 \%$ & $0.020 \%$ \\
\hline
\end{tabular}

${ }^{\dagger}$ Values changed from original run plan to reflect noble metal under addition. 
2) The batching of the materials is designed to produce a glass containing $26 \mathrm{wt} \%$ calcined sludge solids and $74 \mathrm{wt} \%$ frit 200 . A batching summary is shown in Table XXX.

3) Calculated acid addition rates, boilup rates, purge rates, antifoam addition, etc. were based on scaling from DWPF settings as shown in Table XXXI.

4) Run $2 \mathrm{~V}$ simulates normal acid additions for $137.5 \%$ of stoichiometry with a redox target of $0.2 \mathrm{Fe}^{+2} / \mathrm{Fe}$ while Run $3 \mathrm{~V}$ simulates high acid additions for $300 \%$ stoichiometry. The original task plan called for 200 gallons of pre-acid for Run $2 \mathrm{~V}$ but after consultation with DWPF, it was decided to add two-thirds of 200 gallons so there would be some acid left for the regular addition. At the current TNX scale, this means $39 \mathrm{ml}$ of pre-acid will be added for Run $2 \mathrm{~V}$ leaving $3 \mathrm{ml}$ for later to match the required stoichiometric amount. The amount of nitric for Run $3 \mathrm{~V}$ is the same as with $137.5 \%$ stoichiometry and a redox target of $0.2 \mathrm{Fe}^{+2} / \Sigma \mathrm{Fe}$ but the amount of formic is increased to give $300 \%$ stoichiometry. The redox calculation spreadsheets for the Variability Run $2 \mathrm{~V}$ and $3 \mathrm{~V}$ are shown in Table XXXII and Table XXXIII, respectively.

5) A review, as required by the Conduct of Research and Development has been completed and is included in Appendix B.

6) The experiments should be completed the week of January 11, 1999.

Table XXX. Batching Summary for Variability Runs 2V and 3V

\begin{tabular}{|c|c|c|}
\hline Batching Summary & Run 2V & Run 3V \\
\hline Sludge \& Heel Mass & $2833.3 \mathrm{~g}$ & 2733.3 \\
\hline Nitric Acid Volume, $\mathrm{ml}$ & $42.15 \mathrm{ml}$ & $44.91 \mathrm{r}$ \\
\hline Formic Acid Volume, $\mathrm{ml}$ & $106.60 \mathrm{ml}$ & $260.73 n$ \\
\hline SRAT Product Sample, $\mathrm{ml}$ & 125 & 12 \\
\hline Frit 200 Addition \#1, g & $563.86 \mathrm{~g}$ & 544.64 \\
\hline SME Water Addition \#1, g & $1035.68 \mathrm{~g}$ & 1000.39 \\
\hline SME 90 wt\% Formic Acid Addition \#1, g & $11.49 \mathrm{~g}$ & 11.10 \\
\hline Frit 200 Addition \#2, g & $563.86 \mathrm{~g}$ & 544.64 \\
\hline SME Water Addition \#2, g & $1035.68 \mathrm{~g}$ & 1000.39 \\
\hline SME 90 wt $\%$ Formic Acid Addition \#2, g & $11.49 \mathrm{~g}$ & 11.10 \\
\hline SRAT Air Purge & 466.5 & 466. \\
\hline SRAT Helium purge, scc/min & 2.34 & 2.3 \\
\hline SME Air Purge $e^{\ddagger}$ scc/min & 163.8 & 163. \\
\hline SME Helium purge, scc/min & 0.82 & 0.8 \\
\hline
\end{tabular}

${ }^{\ddagger}$ Actual SRAT Gas Purge equivalent to this Air purge plus the Helium Purge. 
Westinghouse Savannah River Company

Savannah River Technology Center

APPENDIX A-3: Runs 2V/3V WSRC-TR-99-00111, Rev. 0

Page 50 of 111

Table XXXI. Scaling Calculations for Large Batch Variability Runs 2V and 3V

\begin{tabular}{|c|c|c|c|c|c|c|}
\hline & DWPF & TNX 2V & Time & DWPF & TNX 3V & Time \\
\hline Scale factor & & $11,355(12831)^{\dagger}$ & & & \multicolumn{2}{|c|}{$11,355(12831)^{\dagger}$} \\
\hline Sludge Added Volume & $7,000 \mathrm{gal}$ & $2065 \mathrm{ml}$ & & 7,000 gal & $2065 \mathrm{ml}$ & \\
\hline Sludge Heel Volume & $1,500 \mathrm{gal}$ & $442 \mathrm{ml}$ & & $1,200 \mathrm{gal}$ & $354 \mathrm{ml}$ & \\
\hline Sludge Added Density & 1.13 & 1.13 & & 1.13 & 1.13 & \\
\hline Sludge Heel Density & 1.13 & 1.13 & & 1.13 & 1.13 & \\
\hline Sludge Added Mass & $29941 \mathrm{~kg}$ & $2333.3 \mathrm{~g}$ & & $29941 \mathrm{~kg}$ & $2333.3 \mathrm{~g}$ & \\
\hline Sludge Heel Mass & $6416 \mathrm{~kg}$ & $500.0 \mathrm{~g}$ & & $5133 \mathrm{~kg}$ & $400.0 \mathrm{~g}$ & \\
\hline SRAT Added Water & $1,000 \mathrm{gal}$ & $295.0 \mathrm{ml}$ & $2.2 \mathrm{hrs}$ & $1,000 \mathrm{gal}$ & $295.0 \mathrm{ml}$ & $3.0 \mathrm{hrs}$ boil \\
\hline SRAT purge air ${ }^{\ddagger}$ & $188 \mathrm{scfm}$ & $466.5 \mathrm{scc} / \mathrm{min}$ & & $188 \mathrm{scfm}$ & $\begin{array}{c}466.5 \\
\mathrm{scc} / \mathrm{min}\end{array}$ & \\
\hline SRAT He purge & $0.50 \mathrm{vol} \%$ & $2.34 \mathrm{scc} / \mathrm{min}$ & & $0.50 \mathrm{vol} \%$ & $\begin{array}{c}2.34 \\
\mathrm{scc} / \mathrm{min}\end{array}$ & \\
\hline SME purge air & $66 \mathrm{scfm}$ & $163.8 \mathrm{scc} / \mathrm{min}$ & & $66 \mathrm{scfm}$ & $\begin{array}{c}163.8 \\
\mathrm{scc} / \mathrm{min}\end{array}$ & \\
\hline SME He purge & $0.50 \mathrm{vol} \%$ & $0.82 \mathrm{scc} / \mathrm{min}$ & & $0.50 \mathrm{vol} \%$ & $\begin{array}{c}0.82 \\
\mathrm{scc} / \mathrm{min}\end{array}$ & \\
\hline Antifoam (100 ppm in Total Sludge) & $8.02 \mathrm{lbs}$ & $0.23 \mathrm{~g}$ & & $7.73 \mathrm{lbs}$ & $0.23 \mathrm{~g}$ & \\
\hline Antifoam Solution (20 to I solution) & $160.31 \mathrm{lbs}$ & $4.67 \mathrm{~g}$ & & $154.65 \mathrm{lbs}$ & $4.67 \mathrm{~g}$ & \\
\hline Elemental Hg to Reduce & & & & & $46.10 \mathrm{~g}$ & \\
\hline nitric acid feedrate & $2 \mathrm{gpm}$ & $0.669 \mathrm{ml} / \mathrm{min}$ & $1.0 \mathrm{hrs}$ & $2 \mathrm{gpm}$ & $\begin{array}{c}0.669 \\
\mathrm{ml} / \mathrm{min}\end{array}$ & $1.1 \mathrm{hrs}$ \\
\hline formic acid feedrate & $2 \mathrm{gpm}$ & $0.687 \mathrm{ml} / \mathrm{min}$ & $2.7 \mathrm{hrs}$ & $2 \mathrm{gpm}$ & $\begin{array}{c}0.687 \\
\mathrm{~m} 1 / \mathrm{min}\end{array}$ & $6.5 \mathrm{hrs}$ \\
\hline boilup rate & $5,000 \mathrm{lb} / \mathrm{hr}$ & $3.33 \mathrm{~g} / \mathrm{min}$ & & $5,000 \mathrm{lb} / \mathrm{hr}$ & $3.33 \mathrm{~g} / \mathrm{min}$ & \\
\hline Formic Molarity & $23.55 \mathrm{M}$ & $22.85 \mathrm{M}$ & & $23.55 \mathrm{M}$ & $22.85 \mathrm{M}$ & \\
\hline Nitric Molarity & $10.35 \mathrm{M}$ & $10.32 \mathrm{M}$ & & $10.35 \mathrm{M}$ & $10.32 \mathrm{M}$ & \\
\hline Formic Volume & $310.3 \mathrm{gal}$ & $106.60 \mathrm{ml}$ & & $758.9 \mathrm{gal}$ & $260.73 \mathrm{ml}$ & \\
\hline Formic Mass & & $128.39 \mathrm{~g}$ & & & $314.02 \mathrm{~g}$ & \\
\hline Nitric Volume & $126.1 \mathrm{gal}$ & $42.15 \mathrm{ml}$ & & $134.3 \mathrm{gal}$ & $44.91 \mathrm{ml}$ & \\
\hline Nitric Mass & & $55.15 \mathrm{~g}$ & & & $58.77 \mathrm{~g}$ & \\
\hline formic feed time & $155.1 \mathrm{~min}$ & $155.1 \mathrm{~min}$ & & $379.4 \mathrm{~min}$ & $379.4 \mathrm{~min}$ & \\
\hline Nitric feed time & $63.0 \mathrm{~min}$ & $63.0 \mathrm{~min}$ & & $67.2 \mathrm{~min}$ & $67.2 \mathrm{~min}$ & \\
\hline Total Vol & & $2951.07 \mathrm{ml}$ & & & $3019.46 \mathrm{ml}$ & \\
\hline Frit Volume, gallons & $3,759 \mathrm{gal}$ & $1253.018 \mathrm{~g}$ & & $3,631 \mathrm{gal}$ & $1210.319 \mathrm{~g}$ & \\
\hline Frit Density & 1.5 & & & 1.5 & & \\
\hline Frit wt \% solids & $60 \%$ & & & $60 \%$ & & \\
\hline Frit Solids & $28,231.0 \mathrm{lbs}$ & $1127.716 \mathrm{~g}$ & & $27,269.0 \mathrm{lbs}$ & $1089.287 \mathrm{~g}$ & \\
\hline Formic Acid & $517.6 \mathrm{lbs}$ & $20.675 \mathrm{~g}$ & & $499.9 \mathrm{lbs}$ & $19.970 \mathrm{~g}$ & \\
\hline Water & $33,987.0 \mathrm{lbs}$ & $1357.645 \mathrm{~g}$ & & $32,828.9 \mathrm{lbs}$ & $1311.381 \mathrm{~g}$ & \\
\hline Transfer Water & $17,924.5 \mathrm{lbs}$ & $716.010 \mathrm{~g}$ & & $17,313.7 \mathrm{lbs}$ & $691.611 \mathrm{~g}$ & \\
\hline \begin{tabular}{|l|} 
Total Water \\
\end{tabular} & $51,911.5 \mathrm{lbs}$ & $2073.655 \mathrm{~g}$ & & $50,142.5 \mathrm{lbs}$ & $2002.992 \mathrm{~g}$ & \\
\hline Total & $80,660.1 \mathrm{lbs}$ & $3222.045 \mathrm{~g}$ & & $77,911.5 \mathrm{lbs}$ & $3112.249 \mathrm{~g}$ & \\
\hline
\end{tabular}

${ }^{\dagger}$ Correct scale factor in parentheses, value off due to improper density correction.

${ }^{t}$ Actual SRAT Gas Purge equivalent to this Air purge plus the Helium Purge. 
Westinghouse Savannah River Company

Savannah River Technology Center
APPENDIX A-3: Runs 2V/3V WSRC-TR-99-00111, Rev. 0

Page 51 of 111

Table XXXI. Scaling Calculations for Large Batch Variability Runs $2 \mathrm{~V}$ and $3 \mathrm{~V}$ Continued

\begin{tabular}{|c|c|c|c|c|c|c|}
\hline & DWPF & TNX 2V & Time & DWPF & TNX 3V & Time \\
\hline frit 200 & $28,231.0 \mathrm{lbs}$ & $1127.716 \mathrm{~g}$ & & $27,269.0 \mathrm{lbs}$ & $1089.287 \mathrm{~g}$ & \\
\hline $90 \mathrm{wt} \%$ formic acid & $575.1 \mathrm{lbs}$ & $22.972 \mathrm{~g}$ & & $555.5 \mathrm{lbs}$ & $22.189 \mathrm{~g}$ & \\
\hline \begin{tabular}{|l|} 
water \\
\end{tabular} & $51,854.0 \mathrm{lbs}$ & $2071.357 \mathrm{~g}$ & & $50,087.0 \mathrm{lbs}$ & $2000.773 \mathrm{~g}$ & \\
\hline Total & $80,660.1 \mathrm{lbs}$ & $3222.045 \mathrm{~g}$ & & $77,911.5 \mathrm{lbs}$ & $3112.249 \mathrm{~g}$ & \\
\hline frit 200 Addition 1 & $14,115.5 \mathrm{lbs}$ & $563.858 \mathrm{~g}$ & & $13,634.5 \mathrm{lbs}$ & $544.644 \mathrm{~g}$ & \\
\hline $90 \mathrm{wt} \%$ formic addition I & $287.5 \mathrm{lbs}$ & $11.486 \mathrm{~g}$ & & $277.7 \mathrm{lbs}$ & $11.095 \mathrm{~g}$ & \\
\hline water addition I & $25,927.0 \mathrm{lbs}$ & $1035.679 \mathrm{~g}$ & $5.2 \mathrm{hrs}$ & $25,043.5 \mathrm{lbs}$ & $1000.386 \mathrm{~g}$ & $5.0 \mathrm{hrs}$ \\
\hline frit 200 Addition 2 & $14,115.5 \mathrm{lbs}$ & $563.858 \mathrm{~g}$ & & $13,634.5 \mathrm{lbs}$ & $544.644 \mathrm{~g}$ & \\
\hline $90 \mathrm{wt} \%$ formic addition 2 & $287.5 \mathrm{lbs}$ & $11.486 \mathrm{~g}$ & & $277.7 \mathrm{lbs}$ & $11.095 \mathrm{~g}$ & \\
\hline water addition 2 & $25,927.0 \mathrm{lbs}$ & $1035.679 \mathrm{~g}$ & $5.2 \mathrm{hrs}^{\prime}$ & $25,043.5 \mathrm{lbs}$ & $1000.386 \mathrm{~g}$ & $5.0 \mathrm{hrs}$ \\
\hline
\end{tabular}

Table XXXII. Large Batch Variability Run 2V Redox Calculation

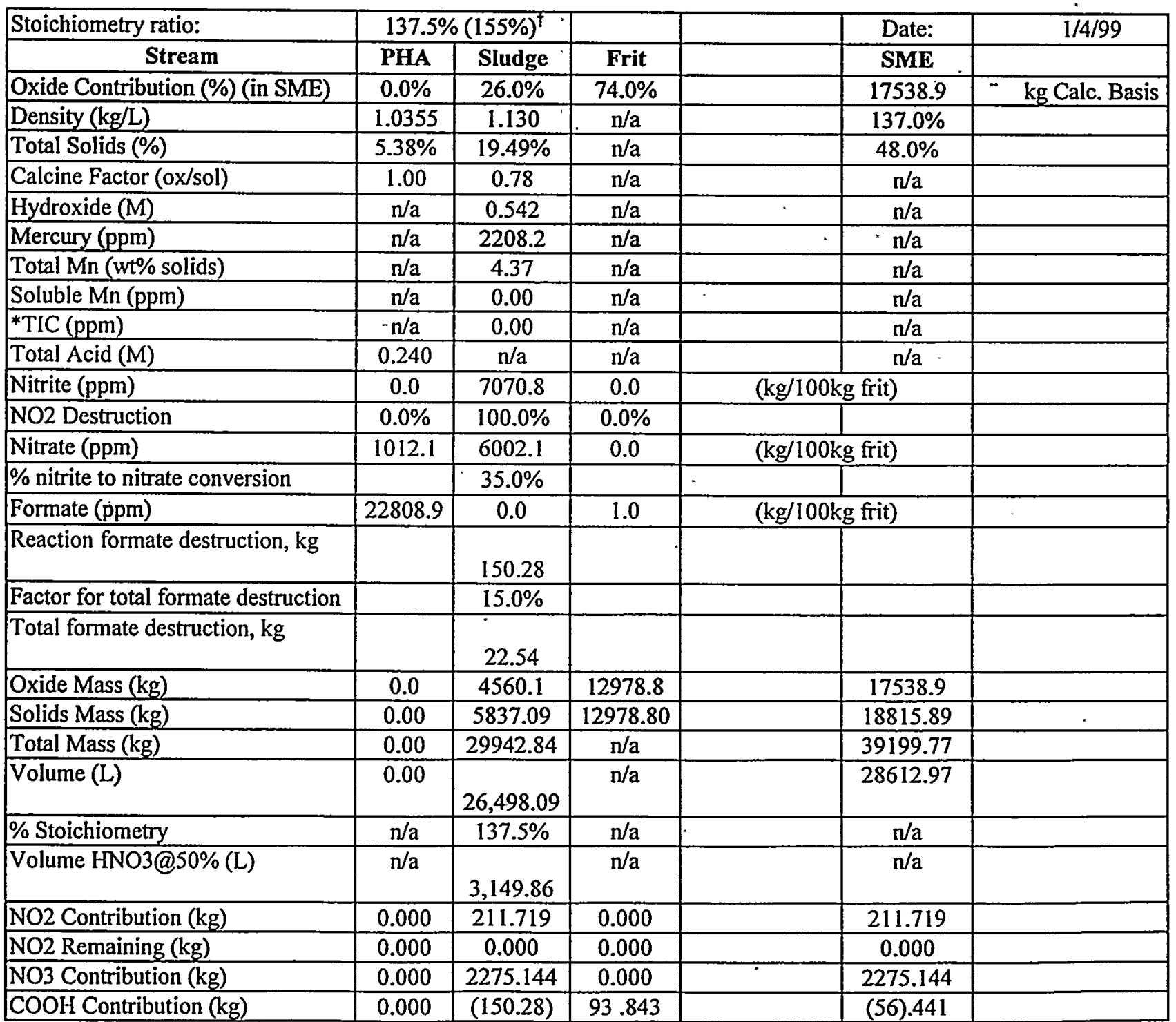

${ }^{t}$ Value in parentheses represents corrected value due to scale factor error. 
Table XXXII. Large Batch Variability Run 2V Redox Calculation Continued

\begin{tabular}{|c|c|c|c|c|c|c|}
\hline Stoichiometry ratio: & $137.5 \%$ & $(155 \%)^{\dagger}$ & & & Date: & $1 / 4 / 99$ \\
\hline Stream & PHA & Sludge & Frit & & SME & \\
\hline NO2 (Molar@45\%) & & & & & 0.000 & \\
\hline NO3 (Molar@45\%) & & & & & 1.556 & \\
\hline $\mathrm{COOH}$ (Molar@45\%) & & & & & -0.053 & \\
\hline Predicted $\mathrm{Fe}(\mathrm{II}) / \sum \mathrm{Fe}$ & & & 0.09 & $\leq$ & BDL@0.03 & 0.1 \\
\hline Volume HCOOH@90\% (L) & & & 3962.99 & & 3645.89 & 4015.91 \\
\hline$\%$ Stoichiometry & $n / a$ & $137.5 \%$ & $\mathrm{n} / \mathrm{a}$ & & $\mathrm{n} / \mathrm{a}$ & \\
\hline Volume HCOOH@90\% (L) & $n / a$ & $1,384.19$ & $\mathrm{n} / \mathrm{a}$ & & $n / a$ & \\
\hline NO2 Contribution (kg) & 0.000 & 211.719 & 0.000 & & 211.719 & \\
\hline NO2 Remaining (kg) & 0.000 & 0.000 & 0.000 & & 0.000 & \\
\hline NO3 Contribution (kg) & 0.000 & 253.822 & 0.000 & & 253.822 & \\
\hline COOH Contribution $(\mathrm{kg})$ & 0.000 & 1445.008 & 93.843 & & 1538.851 & \\
\hline NO2 (Molar@45\%) & & & & & 0.000 & \\
\hline NO3 (Molar@45\%) & & & & & 0.174 & \\
\hline COOH (Molar@45\%) & & & & & 1.450 & \\
\hline Predicted $\mathrm{Fe}(\mathrm{II}) / \mathrm{KFe}$ & - & & 0.09 & $\leq$ & 0.458 & 0.1 \\
\hline Volume HNO3@50\% (L) & & & 1262.94 & & & 1222.87 \\
\hline mol\% Nitric & $n / a$ & $15.2 \%$ & $\mathrm{n} / \mathrm{a}$ & & $\mathrm{n} / \mathrm{a}$ & \\
\hline Volume HCOOH@90\% (L) & $n / a$ & $1,174.49$ & $\mathrm{n} / \mathrm{a}$ & & $\mathrm{n} / \mathrm{a}$ & \\
\hline Volume HNO3@50\% (L) & & 477.20 & & & & \\
\hline NO2 Contribution $(\mathrm{kg})$ & 0.000 & 211.719 & 0.000 & & 211.719 & \\
\hline NO2 Remaining (kg) & 0.000 & 0.000 & 0.000 & & 0.000 & \\
\hline NO3 Contribution $(\mathrm{kg})$ & 0.000 & 560.053 & 0.000 & & 560.053 & \\
\hline $\mathrm{COOH}$ Contribution (kg) & 0.000 & 1094.933 & 0.000 & & 1094.933 & \\
\hline NO2 (Molar@45\%) & & & & & 0.000 & $\ldots$ \\
\hline NO3 (Molar@45\%) & & & & & 0.383 & $\ldots$ \\
\hline COOH (Molar@45\%) & & & & & 1.031 & \\
\hline Predicted $\mathrm{Fe}(\mathrm{II}) / \Sigma \mathrm{Fe}$ & & & 0.09 & $\leq$ & $0.200(0.217)^{\dagger}$ & 0.1 \\
\hline
\end{tabular}

${ }^{t}$ Value in parentheses represents corrected value due to scale factor error. 
Table XXXIII. Large Batch Variability Run 3V Redox Calculation

\begin{tabular}{|c|c|c|c|c|c|c|}
\hline Stoichiometry ratio & \multicolumn{2}{|c|}{$300 \%(340 \%)^{\dagger}$} & & Date: & $1 / 7 / 99$ & \\
\hline $\begin{array}{c}\text { Stream } \\
\end{array}$ & PHA & Sludge & Frit & & SME & \\
\hline Oxide Contribution (\%) (in SME) & $0: 0 \%$ & $26.0 \%$ & $74.0 \%$ & $=$ & 17621.3 & " kg Calc. Basis \\
\hline Density $(\mathrm{kg} / \mathrm{L})$ & 1.0355 & 1.130 & $\mathrm{n} / \mathrm{a}$ & & $137.0 \%$ & \\
\hline Total Solids (\%) & $5.38 \%$ & $19.46 \%$ & $\mathrm{n} / \mathrm{a}$ & & $48.0 \%$ & \\
\hline Calcine Factor (ox/sol) & 1.00 & 0.79 & $\mathrm{n} / \mathrm{a}$ & & $\mathrm{n} / \mathrm{a}$ & \\
\hline Hydroxide $(\mathrm{M})$ & $\mathrm{n} / \mathrm{a}$ & 0.560 & $\mathrm{n} / \mathrm{a}$ & - & $\mathrm{n} / \mathrm{a}$ & \\
\hline Mercury (ppm) & $\mathrm{n} / \mathrm{a}$ & 2250.2 & $n / a$ & & $\mathrm{n} / \mathrm{a}$ & \\
\hline Total Mn (wt\% solids) & $n / a$ & 4.38 & $\mathrm{n} / \mathrm{a}$ & & $\mathrm{n} / \mathrm{a}$ & \\
\hline Soluble Mn (ppm) & $\mathrm{n} / \mathrm{a}$ & 0.00 & $\mathrm{n} / \mathrm{a}$ & & $\mathrm{n} / \mathrm{a}$ & \\
\hline *TIC (ppm) & $\mathrm{n} / \mathrm{a}$ & 0.00 & $\mathbf{n} / \mathbf{a}$ & & $\mathrm{n} / \mathrm{a}$ & \\
\hline Total Acid (M) & 0.240 & $n / a$ & $\mathrm{n} / \mathrm{a}$ & & $\mathrm{n} / \mathrm{a}$ & \\
\hline Nitrite (ppm) & 0.0 & 7308.7 & 0.0 & $(\mathrm{~kg} / \mathrm{l}$ & frit) & \\
\hline NO2 Destruction & $0.0 \%$ & $100.0 \%$ & $0.0 \%$ & $\cdot$ & & \\
\hline Nitrate $(\mathrm{ppm})$ & 1012.1 & 5565.6 & 0.0 & $(\mathrm{~kg} / 1$ & frit) & : \\
\hline$\%$ nitrite to nitrate conversion & & $35.0 \%$ & & & & \\
\hline Formate (ppm) & 22808.9 & 0.0 & 1.0 & $(\mathrm{~kg} / 1$ & frit) & \\
\hline Reaction formate destruction, $\mathrm{kg}$ & & 152.31 & & & & \\
\hline Factor for total formate destruction & & $15.0 \%$ & & & & \\
\hline Total formate destruction, $\mathrm{kg}$ & & 22.85 & & & & \\
\hline Oxide Mass (kg) & 0.0 & 4581.5 & 13039.8 & & 17621.3 & \\
\hline Solids Mass (kg) & 0.00 & 5827.17 & 13039.78 & & 18866.95 & \\
\hline Total Mass (kg) & 0.00 & 29942.84 & n/a & & 39306.14 & \\
\hline Volume (L) & 0.00 & $26,498.09$ & $\mathrm{n} / \mathrm{a}$ & & 28690.62 & \\
\hline \% Stoichiometry & $\mathrm{n} / \mathrm{a}$ & $300.0 \%$ & $\mathrm{n} / \mathrm{a}$ & & $\mathrm{n} / \mathrm{a}$ & \\
\hline Volume HNO3@50\% (L) & $\mathrm{n} / \mathrm{a}$ & $7,045.36$ & $\mathrm{n} / \mathrm{a}$ & & $\mathrm{n} / \mathrm{a}$ & \\
\hline NO2 Contribution $(\mathrm{kg})$ & 0.000 & 218.842 & 0.000 & & 218.842 & \\
\hline NO2 Remaining (kg) & 0.000 & 0.000 & 0.000 & & 0.000 & \\
\hline NO3 Contribution $(\mathrm{kg})$ & 0.000 & 4764.377 & 0.000 & & 4764.377 & \\
\hline COOH Contribution $(\mathrm{kg})$ & 0.000 & $(152.31)$ & 93.843 & & $(58) .463$ & \\
\hline NO2 (Molar@45\%) & . & & & & 0.000 & \\
\hline NO3 (Molar@45\%) & & & & & 3.258 & \\
\hline COOH (Molar@45\%) & & & & & -0.055 & \\
\hline Predicted $\mathrm{Fe}(\mathrm{II}) / \Sigma \mathrm{Fe}$ & & & 0.09 & $\leq$ & BDL@0.03 & 0.1 \\
\hline Volume HCOOH@90\% (L) & & & 9024.87 & & 8701.99 & 9078.73 \\
\hline$\%$ Stoichiometry & $\mathrm{n} / \mathrm{a}$ & $300.0 \%$ & $\mathrm{n} / \mathrm{a}$ & & $\mathrm{n} / \mathrm{a}$ & \\
\hline Volume HCOOH@90\%(L) & $\mathrm{n} / \mathrm{a}$ & $3,096.05$ & $\mathrm{n} / \mathrm{a}$ & & $\mathrm{n} / \mathrm{a}$ & \\
\hline NO2 Contribution (kg) & 0.000 & 218.842 & 0.000 & & 218.842 & \\
\hline NO2 Remaining (kg) & 0.000 & 0.000 & 0.000 & & 0.000 & \\
\hline NO3 Contribution (kg) & 0.000 & 243.245 & 0.000 & & 243.245 & \\
\hline $\mathrm{COOH}$ Contribution $(\mathrm{kg})$ & 0.000 & 3259.655 & 93.843 & & 3353.498 & \\
\hline
\end{tabular}

'Value in parentheses represents corrected value due to scale factor error. 
Westinghouse Savannah River Company

Savannah River Technology Center

Table XXXIII. Large Batch Variability Run 3V Redox Calculation Continued

\begin{tabular}{|l|c|c|c|c|c|c|}
\hline \multicolumn{1}{|c|}{ Stoichiometry ratio: } & \multicolumn{2}{|c|}{$300 \%(340 \%)^{\dagger}$} & & Date: & $1 / 7 / 99$ & \\
\hline Stream & PHA & Sludge & Frit & & SME & \\
\hline NO2 (Molar@45\%) & & & & & 0.000 & \\
\hline NO3 (Molar@45\%) & & & & & 0.166 & \\
\hline COOH (Molar@45\%) & & & & & 3.159 & \\
\hline Predicted Fe(II)//Fe & & & 0.09 & $\leq$ & 0.888 & $\leq$ \\
\hline Volume HNO3@50\% (L) & & & 2590.82 & & & 2550.56 \\
\hline mol\% Nitric & $\mathrm{n} / \mathrm{a}$ & $7.2 \%$ & $\mathrm{n} / \mathrm{a}$ & & $\mathrm{n} / \mathrm{a}$ & \\
\hline Volume HCOOH@90\% (L) & $\mathrm{n} / \mathrm{a}$ & & $\mathrm{n} / \mathrm{a}$ & & $\mathrm{n} / \mathrm{a}$ & \\
& & $2,872.58$ & & & & \\
\hline Volume HNO3@50\% (L) & & & & & & \\
& & 508.53 & & & & \\
\hline NO2 Contribution (kg) & 0.000 & 218.842 & 0.000 & & 218.842 & \\
\hline NO2 Remaining (kg) & 0.000 & 0.000 & 0.000 & & 0.000 & \\
\hline NO3 Contribution (kg) & 0.000 & 569.580 & 0.000 & & 569.580 & \\
\hline COOH Contribution (kg) & 0.000 & 2893.264 & 0.000 & & 2893.264 & \\
\hline NO2 (Molar@45\%) & & & & & 0.000 & \\
\hline NO3 (Molar@45\%) & & & & & 0.390 & \\
\hline COOH (Molar@45\%) & & & & & 2.725 & \\
\hline Predicted Fe(II)/2Fe & & & 0.09 & $\leq$ & $0.615(0.688)^{\dagger}$ & $\leq$ \\
\hline
\end{tabular}

${ }^{t}$ Value in parentheses represents corrected value due to scale factor error. 
Westinghouse Savannah River Company Savannah River Technology Center
APPENDIX A-3: Runs 2V/3V

Run \# $2 V \& 3 V$
WSRC-TR-99-00111, Rev. 0

Page 55 of 111

Date: 1/13/99

\section{PREREQUISITES}

1. $\$$ Signed TAR requesting work.

2. Wissued Testing scope and taș assignment.

2. Vy Analyze sludge for density, ivial base (pH 5.5), nitrate, manganese, nitrite, density, solids.

4. Calibrate GC. Calibrate for nitrogen, oxygen, N2O, hydrogen, and carbon dioxide.

5. Drepare sufficient $90 \%$ formic acid and $50 \%$ nitric acid.

6. Drepare sufficient antifoam solution or make sure sufficient solution is available.

7. Calculate batching and scaling for experiment based on DWPF parameters.

8. Calculate redox for experiment based on DWPF parameters.

9. $\mathrm{H}$ Setup 2 experimental rigs per sketch below.

10. Complete leak checks and water runs.

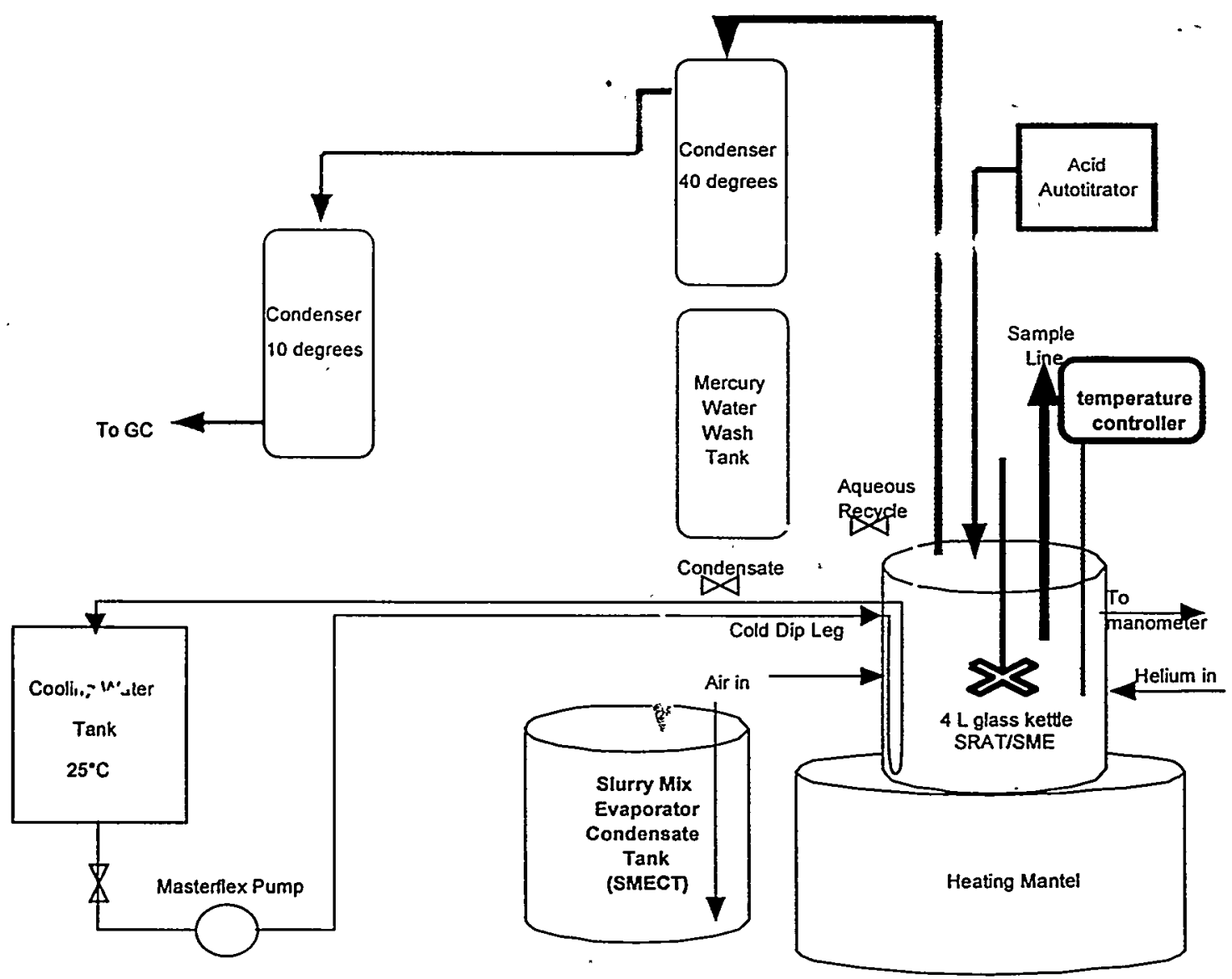


Westinghouse Savannah River Company Savannah River Technology Center

Run \# 2V
APPENDIX A-3: Runs 2V/3V

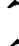

WSRC-TR-99-00111, Rev. 0

Page 56 of 111

Date: $1 / 12 / 99$

\section{PREPARATION FOR SRAT CYCLE}

Note: Do not insulate kettle until acid addition is complete

1. $\$$ Add $2000 \mathrm{~g}$ of Sludge $\mathrm{A}^{\prime}$ to kettle using 2-liter transfer bottle or beaker.

2. Add $500.0 \mathrm{~g}$ of SRAT Heel $\mathrm{A}^{\prime}$ to kettle using 2-liter transfer bottle or beaker.

3. Vurn on kettle agitator. Setpoint $=\mathbf{2 0 0} \mathbf{~ r p m}$. Mark Sludge Level in Kettle as De-water Level for later de-

watering and concentration.

4. Add first batch of trim chemicals (from Table XXVI) directly to the kettle.

5. Transfer $295 \mathrm{mI}$ of distilled water to the kettle (use to rinse all containers used for adding sludge, noble

6. metals, mercury, etc.).

6. Calibrate pH probe with pH 4 and 10 buffer. Record measured $\mathrm{pH}$ of $\mathrm{pH} 7$ buffer $\underline{7.031}$.

7. Jnstall $\mathrm{pH}$ probe in kettle. Record initial $\mathrm{pH}$ of sludge 11.70 .

8. $\nabla$ Turn on the air purge to kettle at $100.0 \mathrm{sccm}$. Connect the outlet flowmeter to perform the leak check. The outlet flow should be $90-110 \mathrm{sccm}$. If it is not, tighten all connections until the system is leak tight. Write 9 down the leak check in the logbook.

9. Disconnect outlet flowmeter.

10. $\nabla$ Turn on the air purge to kettle at $466.5 \mathrm{sccm}$. Turn on He purge and set to $2.34 \mathrm{sccm}$.

11. Wrurn on cooling water to SRAT condenser. Setpoint $=40^{\circ} \mathrm{C}$.

12. $\nabla$ rurn on cooling water to Chilled (FAVC) condenser. Setpoint $=10^{\circ} \mathrm{C}$.

13. Make sure the GC computer has enough memory space for the run (at least 40 Mbyte).

14. Set the GC computer time equal to the clock time. Record the time in the log book.

15. Install the calibration gas cylinder to the GC and let the GC run five times. If at the end of five runs the GC reading is within $10 \%$ of the gas composition in the cylinder, print the calibration check results and write down "pre-cal check and run number" on the printout. Otherwise, select "Calibration" "Level 1" "OK" to calibrate the GC five times. At the end of five runs the $\mathrm{GC}$ reading should be within $10 \%$ of the gas composition in the cylinder. If it is not, contact the engineer. Print the calibration check results and write Nown "pre-cal check and run number" on the printout.

16. W Start the GC for this run beginning with baseline reading for a few minutes. Write down the GC time, filename etc. in the logbook. Record the baseline data on the data sheet. 
Wesfinghouse Savannah River Company Savannah River Technology Center

Run \# $2 \mathrm{~V}$
APPENDIX A-3: Runs 2V/3V

WSRC-TR-99-00111, Rev. 0

Page 57 of 111

Date: $1 / 13 / 99$

\section{SRAT CYCLE}

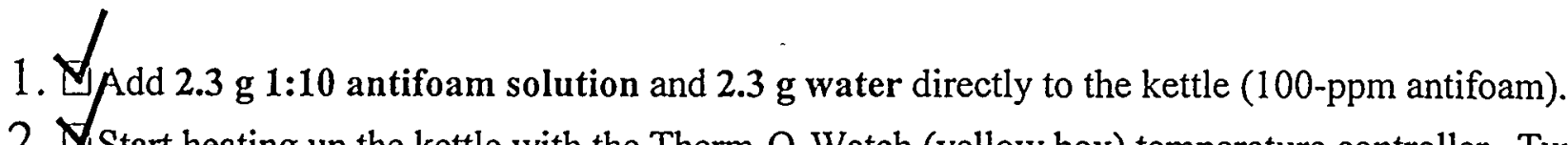

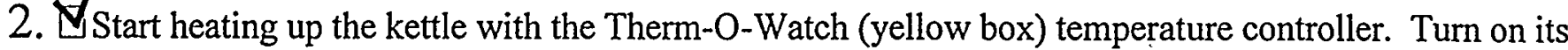
power switch, press the [SEL] key for 3 seconds until display shows "roFF". Press the [^] key until display shows "rrUn" then press and hold the [SEL] key until the normal display appears. The Therm-O-Watch will ramp up to $93^{\circ} \mathrm{C}$ and hold at $93^{\circ} \mathrm{C}$. Record the run data every 20 minutes on the data sheet.

3. $\nabla$ Once at $93^{\circ} \mathrm{C}$, add $39.33 \mathrm{ml}$ of $50-w t \%$ nitric acid at $0.669 \mathrm{ml} / \mathrm{min}$ (reference Table XXVIII) to the kettle. Should take about 1 hour.

4. $\checkmark$ Switch off the Therm-O-Watch, hook the heating mantle to the Cole-Parmer (gray box) temperature controller, and switch on the Cole-Parmer unit. Bring the kettle contents to boiling.

5. If slurry begins to foam over at any time, switch off heating and turn on the cooling coil water pump to bring the temperature down rapidly. Add antifoam solution as shown in Step 1. Then pwitch off the cooling coil water pump and slowly heat up the kettle again to the point of boiling.

6. Dewater until kettle volume returns to De-water Level marked in Step 3 of PREPARATION FOR SRAT CYCLE (approximately $2.2 \mathrm{~L}$ ). Should take about 1 hour and 45 minutes. $(339 \mathrm{~g}$ )

7. When dewatering is complete, turn off the heat to kettle, turn on water to cooling coil, and cool the

kettle to sub-boiling $\left(90^{\circ} \mathrm{C}\right)$.

8. ${ }_{\text {Add } 333.3} \mathrm{~g}$ of Sludge $\mathrm{A}^{\prime}$ to the kettle using 2-liter transfer bottle or beaker.

9. 7 Add second batch of trim chemicals (from Table XXVII) directly to the kettle.

10. $\forall$ Transfer $50 \mathrm{ml}$ of distilled water to the kettle (use to rinse all containers used for adding sludge, noble metals, mercury, etc.). (50.4 $\mathrm{g}$ used)

11. $\triangle$ Allow slurry to cool to $50^{\circ} \mathrm{C}$, monitoring torque every 20 minutes.

12. $\$$ Pull $10 \mathrm{ml}$ sample for nitrate, nitrite, and formate analysis. Add $1 \mathrm{ml}$ of $1 \mathrm{~N} \mathrm{NaOH}$ solution and label the sample LB SRAT 2V*-0N.

13. Start heating up the kettle with the Therm-O-Watch (yellow box) temperature controller. Turn on its power switch, press the [SEL] key for 3 seconds until display shows "roFF". Press the [^] key until display shows "rrUn" then press and hold the [SEL] key until the normal display appears. The Therm-O-Watch will ramp up to $93^{\circ} \mathrm{C}$ and hold at $93^{\circ} \mathrm{C}$. Record the run data every 20 minutes on the data sheet.

14. $\forall$ Once at $93^{\circ} \mathrm{C}$, add $2.82 \mathrm{ml}$ of $50-w t \%$ nitric acid at $0.669 \mathrm{ml} / \mathrm{min}$ (reference Table XXVIII) to the kettle. Should take about 5 minutes.

15. Add $106.60 \mathrm{ml}$ of 90 -wt\% formic acid at $0.687 \mathrm{ml} / \mathrm{min}$ (reference Table XXVIII) to the kettle. Should take about 2 hours and 45 minutes.

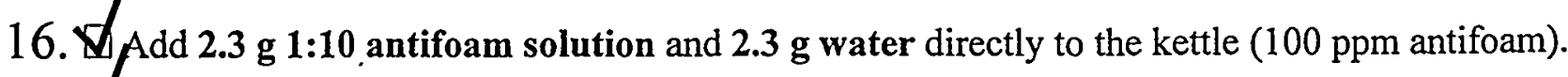

17. Switch off the Therm-O-Watch, hook the heating mantle to the Cole-Parmer (gray box) temperature controller, and switch on the Cole-Parmer unit. Bring the kettle contents to boiling. 
Westinghouse Savannah River Company

Savannah River Technology Center
APPENDIX A-3: Runs 2V/3V

WSRC-TR-99-00111, Rev. 0

Page 58 of 111

Date:

$1 / 13 / 99$

\section{$\underline{\text { SRAT CYCLE (continued) }}$}

18. Dewater until collect $892 \mathrm{~g}$ of $\mathbf{H 2 O}$ in the SMECT leaving approximately $1.8 \mathrm{~L}$ in the kettle. Should pake about 4.5 hours. (Collected $896.3 \mathrm{~g}$ )

19. Pull $10 \mathrm{ml}$ sample for nitrate, nitrite, and formate analysis. Add $1 \mathrm{ml}$ of $1 \mathrm{~N} \mathrm{NaOH}$ solution and

20. Mabel LB SRAT $2 V^{*}-1 \mathrm{~N}$.
Add $2.3 \mathrm{~g} \mathrm{1:10}$ antifoam solution and $2.3 \mathrm{~g}$ water directly to the kettle (100 ppm antifoam).

21. Reflux the slurry for a total of 14 hours (including the dewater time in step 18) at $3.4 \mathrm{~g} / \mathrm{min}$ boilup taking $10 \mathrm{ml}$ sample for nitrate, nitrite, and formate analysis every 2 hours and one at the end then turn off the heat to cool the kettle to sub-boiling. Add $1 \mathrm{ml}$ of $1 \mathrm{~N} \mathrm{NaOH}$ solution to each pample and label as LB SRAT $2 V^{*}-2 \mathrm{~N}, 4 \mathrm{~N}, 6 \mathrm{~N}, 8 \mathrm{~N}$, and $10 \mathrm{~N}$.

22. $\nabla$ Pull a $\underline{125} \mathrm{ml}$ sample from the kettle, record the weight on the run sheet. Label as LB SRAT $2 V^{*}$ final and send to lab for analyses.

23. Vulled extra 125-ml sample LB SRAT-12N for Rheology. 
Westinghouse Savannah River Company Savannah River Technology Center

Run \#

2V
APPENDIX A-3: Runs 2V/3V 
Westinghouse Savannah River Company

Savannah River Technology Center

Run \# 3V
APPENDIX A-3: Runs 2V/3V

WSRC-TR-99-00111, Rev. 0

Page 60 of 111

Date: $1 / 12 / 99$

\section{PREPARATION FOR SRAT CYCLE}

Note: Yo not insulate kettle until acid addition is complete

1. Add $2000 \mathrm{~g}$ of Sludge $\mathrm{A}^{\prime}$ to kettle using 2-liter transfer bottle or beaker.

2. ${ }_{\text {Add }} \mathbf{4 0 0 . 0} \mathrm{g}$ of SRAT Heel $\mathrm{A}^{\prime}$ to kettle using 2-liter transfer bottle or beaker.

3. Turn on kettle agitator. Setpoint $=200 \mathrm{rpm}$. Mark Sludge Level in Kettle as De-water Level for later devatering and concentration.

4. Add first batch of trim chemicals (from Table XXVIII) directly to the kettle.

5. Transfer $295 \mathrm{ml}$ of distilled water to the kettle (use to rinse all containers used for adding sludge, noble (netals, mercury, etc.).

6. Walibrate $\mathrm{pH}$ probe with $\mathrm{pH} 4$ and 10 buffer. Record measured $\mathrm{pH}$ of $\mathrm{pH} 7$ buffer 7.124 .(glass probe)

7. Install $\mathrm{pH}$ probe in kettle. Record initial pH of sludge _13.18.

8. Turn on the air purge to kettle at $\mathbf{1 0 0 . 0} \mathrm{sccm}$. Connect the outlet flowmeter to perform the leak check. The outlet flow should be $\mathbf{9 0 - 1 1 0 ~ s c c m}$. If it is not, tighten all connections until the system is leak tight. Write

9. Misconnect outlet flowmeter.

10. Turn on the air purge to kettle at $466.5 \mathrm{sccm}$. Turn on He purge and set to $2.34 \mathrm{sccm}$.

11. जrurn on cooling water to SRAT condenser. Setpoint $=40^{\circ} \mathrm{C}$.

12. VTurn on cooling water to Chilled (FAVC) condenser. Setpoint $=10^{\circ} \mathrm{C}$.

13. Make sure the GC computer has enough memory space for the run (at least 40 Mbyte).

14. get the GC computer time equal to the clock time. Record the time in the log book.

15. Install the calibration gas cylinder to the GC and let the GC run five times. If at the end of five runs the GC reading is within $10 \%$ of the gas composition in the cylinder, print the calibration check results and write down "pre-cal check and run number" on the printout. Otherwise, select "Calibration" "Level I" "OK" to calibrate the GC five times. At the end of five runs the GC reading should be within $10 \%$ of the gas composition in the cylinder. If it is not, contact the engineer. Print the calibration check results and write plown "pre-cal check and run number" on the printout.

16. $\checkmark$ Start the GC for this run beginning with baseline reading for a few minutes. Write down the GC time, filename etc. in the logbook. Record the baseline data on the data sheet. 
Westinghouse Savannah River Company

Savannah River Technology Center

Run \#

3V
APPENDIX A-3: Runs 2V/3V

WSRC-TR-99-00111, Rev. 0

Page 61 of 111

Date: $\quad 1 / 13 / 99$

\section{SRAT CYCLE}

1. 4 Add $2.3 \mathrm{~g}$ 1:10 antifoam solution and $2.3 \mathrm{~g}$ water directly to the kettle (100 ppm antifoam).

2. UStart heating up the kettle with the Therm-O-Watch (yellow box) temperature controller. Turn on its power switch, press the [SEL] key for 3 seconds until display shows "roFF". Press the [^] key until display shows "rrUn" then press and hold the [SEL] key until the normal display appears. The Therm-O-Watch will ramp up to $93^{\circ} \mathrm{C}$ and hold at $93^{\circ} \mathrm{C}$. Record the run data every 20 minutes on he data sheet.

3. Switch off the Therm-O-Watch, hook the heating mantle to the Cole-Parmer (gray box) temperature Fontroller, and switch on the Cole-Parmer unit. Bring the kettle contents to boiling.

4. If slurry begins to foam over at any time, add antifoam solution as shown in Step 1. If still foaming then switch off heating and turn on the cooling coil water pump to bring the temperature down rapidly. Then switch off the cooling coil water pump and slowly heat up the kettle again to the point of boiling.

5. Dewater until kettle volume returns to De-water Level marked in Step 3 of PREPARATION FOR SRAT CYCLE (approximately $2.1 \mathrm{~L}$ ). Should take about 1 hour and 30 minutes. $(300 \mathrm{~g})$

6. When dewatering is complete, turn off the heat to kettle, turn on water to cooling coil, and cool the kettle to sub-boiling $\left(90^{\circ} \mathrm{C}\right)$.

7. $\forall$ Add $333.3 \mathrm{~g}$ of Sludge $\mathrm{A}^{\prime}$ to the kettle using 2-liter transfer bottle or beaker.

8. Add second batch of trim chemicals (from Table XXIX) directly to the kettle.

9. $\forall$ Transfer $50 \mathrm{ml}$ of distilled water to the kettle (use to rinse all containers used for adding sludge, noble metals, mercury, etc.). Added an additional 31.3 grams.

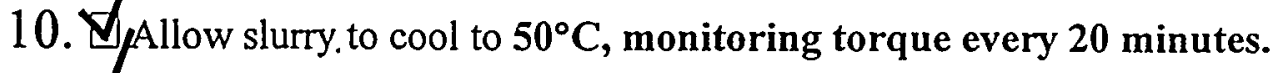

11. Pull $10 \mathrm{ml}$ sample for nitrate, nitrite, and formate analysis. Label LB SRAT 3V*-0N.

12. Start heating up the kettle with the Therm-O-Watch (yellow box) temperature controller. Turn on its power switch, press the [SEL] key for 3 seconds until display shows "roFF". Press the [^] key until display shows "rrUn" then press and hold the [SEL] key until the normal display appears. The Therm-O-Watch will ramp up to $93^{\circ} \mathrm{C}$ and hold at $93^{\circ} \mathrm{C}$. Record the run data every 20 minutes on the data sheet.

13. Once at $93^{\circ} \mathrm{C}$, add $44.90 \mathrm{ml}$ of $50-w t \%$ nitric acid at $0.669 \mathrm{ml} / \mathrm{min}$ (reference Table XXXI) to the kettle. Should take about 1 hour and 6 minutes.

14. $\checkmark$ Add $260.73 \mathrm{ml}$ of $\mathbf{9 0}$-wt $\%$ formic acid at $\mathbf{0 . 6 8 7} \mathrm{ml} / \mathrm{min}$ (reference Table XXXI) to the kettle. Should take about 6 hours and 30 minutes.

15. $\nabla_{\text {Add }} 2.3 \mathrm{~g} 1: 10$ antifoam solution and $2.3 \mathrm{~g}$ water directly to the kettle ( $100 \mathrm{ppm}$ antifoam).

16. Switch off the Therm-O-Watch, hook the heating mantle to the Cole-Parmer (gray box) temperature

controller, and switch on the Cole-Parmer unit. Bring the kettle contents to boiling.

17. Dewater until collect $1031 \mathrm{~g}$ of $\mathbf{H 2 O}$ in the SMECT leaving approximately $1.8 \mathrm{~L}$ in the kettle. Should take about 5 hours. (Removed extra $31 \mathrm{~g}$ for additional water added earlier)

18. $\$$ Pull $10 \mathrm{ml}$ sample for nitrate, nitrite, and formate analysis. Label LB SRAT $3 V^{*}-1 N$.

19. Add $2.3 \mathrm{~g}$ 1:10 antifoam solution and $2.3 \mathrm{~g}$ water directly to the kettle (100 ppm antifoam). 
Westinghouse Savannah River Company

Savannah River Technology Center

Run \# 3V
APPENDIX A-3: Runs 2V/3V

WSRC-TR-99-00111, Rev. 0

Page 62 of 111

Date: $1 / 14 / 99$

\section{SRAT CYCLE (continued)}

20. Reflux the slurry for a total of 14 hours (including the dewater time in step 17) at $3.4 \mathrm{~g} / \mathrm{min}$ boilup taking $10 \mathrm{ml}$ sample for nitrate, nitrite, and formate analysis every 2 hours and one at the end then turn off the heat to cool the kettle to sub-boiling. Add $1 \mathrm{ml}$ of $1 \mathrm{~N} \mathrm{NaOH}$ solution to each pample and label as LB SRAT $3 V^{*}-2 \mathrm{~N}, 4 \mathrm{~N}, 6 \mathrm{~N}, 8 \mathrm{~N}$, and final $\mathrm{N}$.

21. Pull a 125-ml sample from the kettle, record the weight on the run sheet. Label as LB SRAT $3 V^{*}$ and send to lab for analyses. 
Westinghouse Savannah River Company Savannah River Technology Center

Run \# $3 \mathrm{~V}$
APPENDIX A-3: Runs 2V/3V

Date: $\quad 1 / 14 / 99$

\section{SME CYCLE}

1. /Add $2.3 \mathrm{~g} 1: 10$ antifoam solution and $2.3 \mathrm{~g}$ water directly to the kettle (100 ppm antifoam).

2. Add $525.32 \mathrm{~g}$ of frit 200 to the kettle $\left(1^{\text {st }} \text { frit addition - Table XXX) }\right)^{1 !}$.

3. Add $10.70 \mathrm{~g}$ of $90-\mathrm{wt} \%$ formic acid to the kettle $\left(1^{\text {st }}\right.$ formic addition - Table XXX) ${ }^{\prime \prime}$.

4. VAdd $964.9 \mathrm{~g}$ of water to the kettle (1 ${ }^{\text {st }}$ water addition - Table XXX) ${ }^{\text {"I }}$.

\$1y Change air (ch 2) to $0.164 \mathrm{slm}$ and $\mathrm{He}$ (ch 1) to $0.82 \mathrm{sccm}$.

5. Vyring kettle contents to boiling. Record the run data every 20 minutes on the data sheet.

6. When dewatering is complete (about 4 hours and 25 minutes), turn off the heat to cool the kettle to subpoiling. (Remove $870.1 \mathrm{~g}$ )

7. Wadd $525.32 \mathrm{~g}$ of frit 200 to the kettle $\left(2^{\text {nd }}\right.$ frit addition - Table XXX) ${ }^{\prime \prime}$.

8. WAdd $10.70 \mathrm{~g}$ of 90 -wt $\%$ formic acid to the kettle $\left(2^{\text {nd }}\right.$ formic addition - Table XXX)"

9. Add $964.9 \mathrm{~g}$ of water to the kettle $\left(2^{\text {nd }} \text { water addition - Table } \mathrm{XXX}\right)^{11}$.

10. When dewatering is complete (about 4 hours and 25 minutes), turn off the heat to cool the kettle to subpoiling. Turn on cooling water to cooling coil dip-leg. (Remove $870.1 \mathrm{~g}$ ) .

11. Pull a 125-mI sample from the kettle, record the weight on the run sheet. Label as LB SME $3 V^{*}$ and send to pab for analyses.

12. Stop GC and record the GC time and clock time in the log book. Stop recording run data on the data sheet.

13. Install the calibration gas cylinder to the GC and run the post-cal check. If the check indicates OK, print a copy and write "post-cal check and run number" on the printout, then place the GC in standby. If the check is hot within $10 \%$ of the cal gas composition, notify the engineer.

14. Pump kettle contents into a tared bottle. Record the weight on the run sheet.

15. WComplete $\mathrm{pH}$ meter post calibration check. Record measured pH in $\mathrm{pH} 7$ buffer _ 3.8 .

16. Install the outlet flow meter to the purge gas. Change channel 2 to 100 sccm and turn off helium before leak checking.

17. When the kettle is cool $\left(<50^{\circ} \mathrm{C}\right)$, record the outlet purge flow in the log book. (All channels).

18. Whurn off all instruments.

Weigh all kettle pieces and record in lab book.

Take pictures of pH probe, cooling coil, RTD, stirring rod, and thermocouple. Set cooling coil, pH probe, RTD, and thermocouple aside for later examination.

$\forall$ Start setting up rigs for next experiment. 


\title{
APPENDIX A-4: LARGE BATCH RUNS 1V \& 4V
}

\author{
SRT-PTD-99-0004, Rev. 0 \\ CC: E. W. Holtzscheiter, 773-A \\ J. E. Occhipinti, 704-27S \\ L. Marra, 704-25S \\ E. Edwards, 704-25S \\ E. Eibling, 704-1T \\ R. Monson, 704-1T \\ D. P. Lambert, 704-1T \\ M. F. Williams, 704-IT \\ J. W. Duvall, 704-1T \\ M. L. Johnson, 772-T \\ S. O. King, 677-T \\ V. J. Williams, 677-T \\ D. C. Koopman, 704-T
}

January 18, 1999

TO: $\quad$ L.F. Landon, 704-1T

FROM: $\quad$ W. E. Daniel, 704-1T

\section{Run Plan for Large Batch Variability Runs with High Weight\% Solids Sludge for Developing Strategies for Increased CPC Batch Sizes (U)}

This run plan documents the variability runs with high weight percent solids sludge as detailed in the Task Technical Plan for Developing Strategy for Increased CPC Batch Size (WSRC-RP-98-00354) as requested in DWPF Technical Task Request HLW/DWPT/TTR-980013. The experimental work will be controlled using the Laboratory Scale Chemical Process Cell Simulations (Manual L27, Procedure 2.02) and this run plan. This run plan includes many of the experimental details, the instructions for final sludge preparation, the scaling necessary for determining the operating conditions such as feed rates, purge rates, and the steps in completing the SRAT and SME cycles. This document also summarizes the decisions made to complete these experiments.

1) The sludge used for the SRAT Heel preparation is a Tank 42-sludge simulant created from the Optima Tank 51 simulant with the following modifications.

a) A recipe is shown in Table XXXIV that targets a 20 weight percent solids sludge after the trim chemicals (noble metals and mercury) are added. This sludge will be referred to as Sludge $\mathrm{A}^{\prime}$ and its pre-trim measured as well as post-trim predicted elemental weight percent analyses are shown in Table XXXV. Analyses of the SRAT Heel used in these experiments are shown in Table XXXVI.

b) Tank 42 levels of noble metals and mercury will be added to the sludge batches as shown in Table XXXVII through Table XL. These levels will require approximately 14 hours of refluxing in the SRAT to steam strip mercury and meet the DWPF constraint of $0.45 \mathrm{wt} \%$ mercury. 
Westinghouse Savannah River Company Savannah River Technology Center
APPENDIX A-4: Runs IV/4V

WSRC-TR-99-00111, Rev. 0

Page 65 of 111

Table XXXIV. Preparation Of Tank 42 Sludge 22 weight \% (Trim Chemicals Missing)

\begin{tabular}{|c|c|c|}
\hline Component & Amount, $\mathbf{g}$ & Comments \\
\hline Tank 51 sludge simulant & 14613.20 & 18.52 wt\% solids initially \\
\hline Tank 51 supernate & 373.20 & Added Supernate to lower wt\% solids \\
\hline $\mathrm{Al}_{2} \mathrm{O}_{3}$ & 194.98 & \\
\hline $\left.\mathrm{Ni} \mathrm{NO}_{3}\right)_{2}{ }^{*} \mathrm{H}_{2} \mathrm{O}$ & 37.65 & \\
\hline $\mathrm{SiO}_{2}$ & 25.73 & \\
\hline $\mathrm{MnO}_{2}{ }^{*} \mathrm{H}_{2} \mathrm{O}$ & 133.49 & Total Mass @ 71.4 wt\% solids \\
\hline $\mathrm{Water}_{\mathrm{Al}_{2} \mathrm{O}_{3}}^{200.00}$ & \\
\hline $\mathrm{Na}_{2} \mathrm{C}_{2} \mathrm{O}_{4}$ & 1.50 & \\
\hline $\mathrm{NaF}$ & 0.00 & \\
\hline $\mathrm{NaOH}$ & 0.88 & \\
\hline $\mathrm{NaCl}$ & 8.69 & \\
\hline & 0.34 & \\
\hline
\end{tabular}

Table XXXV. Elemental Analyses of Large Batch 22 wt\% Sludge B'

\begin{tabular}{|c|c|c|c|c|c|}
\hline $\begin{array}{c}\text { Insoluble } \\
\text { Species }\end{array}$ & $\begin{array}{c}\text { Measured } \\
\text { Wt\% Solids } \\
\text { Pre-Trim }\end{array}$ & $\begin{array}{c}\text { Predicted Wt\% } \\
\text { Solids Post- } \\
\text { Trim }\end{array}$ & $\begin{array}{c}\text { Soluble } \\
\text { Species }\end{array}$ & $\begin{array}{c}\text { Measured } \\
\text { Wt\% Solids } \\
\text { Pre-Trim }\end{array}$ & $\begin{array}{c}\text { Predicted Wt\% } \\
\text { Solids Post-Trim }\end{array}$ \\
\hline $\mathrm{Al}$ & $5.76 \%$ & $8.63 \%$ & $\mathrm{Al}$ & & $0.02 \%$ \\
\hline${ }^{*} \mathrm{Ag}$ & & $0.04 \%$ & $\mathrm{C} 2 \mathrm{O} 4$ & $0.12 \%$ & $0.15 \%$ \\
\hline $\mathrm{Ca}$ & $2.50 \%$ & $1.98 \%$ & $\mathrm{Cl}$ & $0.02 \%$ & $0.02 \%$ \\
\hline${ }^{*} \mathrm{Cd}$ & & $0.11 \%$ & $\mathrm{CO} 3$ & & $1.79 \%$ \\
\hline $\mathrm{Cl}$ & & $0.02 \%$ & $\mathrm{Cr}$ & & $0.00 \%$ \\
\hline $\mathrm{Cr}$ & & $0.17 \%$ & $\mathrm{~F}$ & $0.01 \%$ & $0.02 \%$ \\
\hline $\mathrm{Cu}$ & $0.02 \%$ & $0.02 \%$ & $\mathrm{~K}$ & & $0.00 \%$ \\
\hline $\mathrm{F}$ & & $0.01 \%$ & $\mathrm{Li}$ & & $0.00 \%$ \\
\hline $\mathrm{Fe}$ & $22.19 \%$ & $22.23 \%$ & $\mathrm{Na}$ & & $0.17 \%$ \\
\hline${ }^{*} \mathrm{Hg}$ & & $1.30 \%$ & $\mathrm{NO} 2$ & $3.74 \%$ & $3.69 \%$ \\
\hline $\mathrm{K}$ & $0.12 \%$ & $0.05 \%$ & $\mathrm{NO} 3$ & $1.62 \%$ & $1.55 \%$ \\
\hline $\mathrm{Li}$ & $0.01 \%$ & $0.00 \%$ & $\mathrm{OH}$ & & $0.11 \%$ \\
\hline $\mathrm{Mg}$ & $1.09 \%$ & $1.13 \%$ & $\mathrm{PO} 4$ & $0.00 \%$ & $0.05 \%$ \\
\hline $\mathrm{Mn}$ & $4.31 \%$ & $4.11 \%$ & $\mathrm{SO} 4$ & $0.21 \%$ & $0.21 \%$ \\
\hline $\mathrm{Na}$ & $6.51 \%$ & $5.86 \%$ & & & \\
\hline $\mathrm{Ni}$ & $0.42 \%$ & $0.41 \%$ & & & \\
\hline $\mathrm{P}$ & & $0.00 \%$ & & & \\
\hline${ }^{*} \mathrm{Pd}$ & & $0.00 \%$ & & & \\
\hline $\mathrm{Pu}$ & & $0.00 \%$ & & & \\
\hline${ }^{*} \mathrm{Rh}$ & & $0.01 \%$ & & & \\
\hline${ }^{*} \mathrm{Ru}$ & & $0.02 \%$ & & & \\
\hline $\mathrm{Se}$ & & $0.00 \%$ & & & \\
\hline $\mathrm{Si}$ & $1.15 \%$ & $1.49 \%$ & & & \\
\hline $\mathrm{Te}$ & & $0.00 \%$ & & & \\
\hline $\mathrm{Ti}$ & $0.05 \%$ & $0.05 \%$ & & & \\
\hline $\mathrm{U}$ & & $0.00 \%$ & & & \\
\hline $\mathrm{Zn}$ & $0.12 \%$ & 0.00 & & & \\
\hline & & & & & \\
\hline & & & & \\
\hline
\end{tabular}


Table XXXVI. Elemental Analyses of Large Batch 20.4 wt\% SRAT Heel prepared from Sludge $A^{\prime}$

\begin{tabular}{|c|c|c|c|}
\hline $\begin{array}{l}\text { Insoluble } \\
\text { Species }\end{array}$ & $\begin{array}{c}\text { Measured } \\
\text { Wt\% Solids }\end{array}$ & $\begin{array}{l}\text { Soluble } \\
\text { Species }\end{array}$ & $\begin{array}{c}\text { Measured } \\
\text { Wt\% Solids }\end{array}$ \\
\hline $\mathrm{Al}$ & $5.30 \%$ & $\mathrm{Al}$ & -- \\
\hline${ }^{*} \mathrm{Ag}$ & -- & $\mathrm{C} 2 \mathrm{O} 4$ & $0.04 \%$ \\
\hline $\mathrm{Ca}$ & $2.04 \%$ & $\mathrm{Cl}$ & $0.16 \%$ \\
\hline${ }^{*} \mathrm{Cd}$ & $0.00 \%$ & $\mathrm{CO} 3$ & -- \\
\hline $\mathrm{Cl}$ & -- & $\mathrm{Cr}$ & -- \\
\hline $\mathrm{Cr}$ & -- & $\mathrm{F}$ & - \\
\hline $\mathrm{Cu}$ & $0.01 \%$ & $\mathrm{~K}$ & -- \\
\hline$F$ & -- & $\mathrm{Li}$ & - \\
\hline $\mathrm{Fe}$ & $20.80 \%$ & $\mathrm{Na}$ & -- \\
\hline *Hg & - & NO2 & $0.12 \%$ \\
\hline $\mathrm{K}$ & $0.14 \%$ & NO3 & $9.07 \%$ \\
\hline $\mathrm{Li}$ & $0.00 \%$ & $\mathrm{OH}$ & -- \\
\hline $\mathrm{Mg}$ & $0.89 \%$ & PO4 & $0.04 \%$ \\
\hline $\mathrm{Mn}$ & $4.17 \%$ & $\mathrm{SO} 4$ & $0.10 \%$ \\
\hline $\mathrm{Na}$ & $7.26 \%$ & & \\
\hline $\mathrm{Ni}$ & $0.32 \%$ & & \\
\hline $\mathrm{P}$ & $0.24 \%$ & & \\
\hline *Pd & $0.045 \%$ & & \\
\hline $\mathrm{Pu}$ & -- & & \\
\hline *Rh & $0.0053 \%$ & & \\
\hline$* \mathrm{Ru}$ & $0.032 \%$ & & \\
\hline $\mathrm{Se}$ & -- & & \\
\hline $\mathrm{Si}$ & $1.17 \%$ & & \\
\hline $\mathrm{Te}$ & $0.00 \%$ & & \\
\hline $\mathrm{Ti}$ & $0.03 \%$ & & \\
\hline $\mathrm{U}$ & -- & & \\
\hline $\mathrm{Zn}$ & $0.11 \%$ & & \\
\hline
\end{tabular}


Table XXXVII. Trim Chemical Addition for First Sludge Addition for Run 1V

\begin{tabular}{|c|c|c|c|c|c|}
\hline & $\begin{array}{c}\text { Target } \\
\text { Addition, } g\end{array}$ & $\begin{array}{c}\text { Actual } \\
\text { Addition, } g\end{array}$ & Wt\% Solids & Target Solids, $\mathrm{g}$ & $\begin{array}{l}\text { Actual Solids } \\
\text { added, } \mathrm{g}\end{array}$ \\
\hline Sludge $B^{\prime}$ & 2000.0 & 2000.0 & $20.2 \%$ & 404.0 & 404.0 \\
\hline Trim Chemicals & \begin{tabular}{c|} 
Target \\
Addition, grams
\end{tabular} & $\begin{array}{c}\text { Actual } \\
\text { Addition, } \\
\text { grams }\end{array}$ & $\begin{array}{c}\text { Elemental Solids } \\
\text { Factor }\end{array}$ & $\begin{array}{l}\text { Target Elemental } \\
\text { Solids, } g\end{array}$ & $\begin{array}{l}\text { Actual Elemental } \\
\text { Solids, } \mathrm{g}\end{array}$ \\
\hline AgNO3 & 0.235 & 0.236 & 0.6349 & 0.149 & 0.150 \\
\hline $\mathrm{Cd}(\mathrm{NO} 3) 2 * 4 \mathrm{H} 2 \mathrm{O}$ & 1.220 & 1.224 & 0.3644 & 0.444 & 0.446 \\
\hline $\mathrm{HgO}$ & 5.366 & 5.366 & 0.9261 & 4.969 & 4.969 \\
\hline $\mathrm{Pd}(\mathrm{NO}) 2 * \mathrm{H} 2 \mathrm{O}$ & 0.021 & 0.021 & $0.1527^{\dagger}$ & 0.009 & $0.003^{\dagger}$ \\
\hline $\mathrm{Rh}(\mathrm{NO} 3) 3 * 2 \mathrm{H} 2 \mathrm{O}$ & 0.068 & 0.068 & $0.0493^{\dagger}$ & 0.021 & $0.003^{t}$ \\
\hline $\mathrm{RuCl3}$ & 0.182 & 0.183 & $0.4174^{\dagger}$ & 0.089 & $0.076^{\dagger}$ \\
\hline
\end{tabular}

\begin{tabular}{|c|c|c|}
\hline Element & $\begin{array}{c}\text { Target Wt\% } \\
\text { Solids }\end{array}$ & $\begin{array}{c}\text { Actual Wt\% } \\
\text { Solids }\end{array}$ \\
\hline $\mathrm{Ag}$ & $0.04 \%$ & $0.04 \%$ \\
\hline $\mathrm{Cd}$ & $0.11 \%$ & $0.11 \%$ \\
\hline $\mathrm{Hg}$ & $1.30 \%$ & $1.30 \%$ \\
\hline $\mathrm{Pd}$ & $0.0022 \%$ & $0.0008 \%^{\dagger}$ \\
\hline $\mathrm{Rh}$ & $0.0053 \%$ & $0.0008 \%^{\dagger}$ \\
\hline $\mathrm{Ru}$ & $0.022 \%$ & $0.019 \%^{\dagger}$ \\
\hline
\end{tabular}

†Values changed from original run plan to reflect noble metal under addition.

Table XXXVIII. Trim Chemical Addition for Second Sludge Addition for Run 1V

\begin{tabular}{|c|c|c|c|c|c|}
\hline & $\begin{array}{c}\text { Target } \\
\text { Addition, } \mathrm{g}\end{array}$ & $\begin{array}{c}\text { Actual } \\
\text { Addition, } \mathrm{g}\end{array}$ & Wt\% Solids & Target Solids, $\mathrm{g}$ & $\begin{array}{l}\text { Actual Solids } \\
\text { added, } g\end{array}$ \\
\hline Sludge B' & 333.3 & 333.3 & $19.3 \%$ & 64.3 & 64.3 \\
\hline Trim Chemicals & $\begin{array}{c}\text { Target } \\
\text { Addition, grams }\end{array}$ & $\begin{array}{c}\text { Actual } \\
\text { Addition, } \\
\text { grams }\end{array}$ & $\begin{array}{c}\text { Elemental Solids } \\
\text { Factor }\end{array}$ & $\begin{array}{l}\text { Target Elemental } \\
\text { Solids, } \mathrm{g}\end{array}$ & $\begin{array}{l}\text { Actual Elemental } \\
\text { Solids, } \mathrm{g}\end{array}$ \\
\hline AgNO3 & 0.040 & 0.041 & 0.6349 & 0.025 & 0.026 \\
\hline $\mathrm{Cd}(\mathrm{NO} 3) 2 * 4 \mathrm{H} 2 \mathrm{O}$ & 0.203 & 0.204 & 0.3644 & 0.074 & 0.074 \\
\hline HgO & 0.945 & 0.945 & 0.9261 & 0.875 & 0.875 \\
\hline $\mathrm{Pd}(\mathrm{NO3}) 2^{*} \mathrm{H} 2 \mathrm{O}$ & 0.003 & 0.003 & $0.1527^{\dagger}$ & 0.001 & $0.00046^{\dagger}$ \\
\hline $\mathrm{Rh}(\mathrm{NO} 3)^{3}{ }^{*} 2 \mathrm{H} 2 \mathrm{O}$ & 0.011 & 0.011 & $0.0493^{\dagger}$ & 0.004 & $0.00054^{\dagger}$ \\
\hline $\mathrm{RuCl3}$ & 0.031 & 0.031 & $0.4174^{\dagger}$ & 0.015 & $0.013^{\dagger}$ \\
\hline
\end{tabular}

\begin{tabular}{|c|c|c|}
\hline Element & $\begin{array}{c}\text { Target Wt\% } \\
\text { Solids }\end{array}$ & $\begin{array}{c}\text { Actual Wt } \% \\
\text { Solids }\end{array}$ \\
\hline $\mathrm{Ag}$ & $0.04 \%$ & $0.04 \%$ \\
\hline $\mathrm{Cd}$ & $0.11 \%$ & $0.11 \%$ \\
\hline $\mathrm{Hg}$ & $1.30 \%$ & $1.30 \%$ \\
\hline $\mathrm{Pd}$ & $0.0022 \%$ & $0.0007 \%^{\dagger}$ \\
\hline $\mathrm{Rh}$ & $0.0053 \%$ & $0.0008 \%^{\dagger}$ \\
\hline $\mathrm{Ru}$ & $0.022 \%$ & $0.020 \%^{\dagger}$ \\
\hline
\end{tabular}

†Values changed from original run plan to reflect noble metal under addition. 
Table XXXIX. Trim Chemical Addition for First Sludge Addition for Run 4V

\begin{tabular}{|c|c|c|c|c|c|}
\hline & $\begin{array}{c}\text { Target } \\
\text { Addition, } \mathrm{g}\end{array}$ & $\begin{array}{c}\text { Actual } \\
\text { Addition, } \mathrm{g}\end{array}$ & Wt\% Solids & Target Solids, g & $\begin{array}{c}\text { Actual Solids } \\
\text { added, } \mathrm{g}\end{array}$ \\
\hline Sludge B' & $\mathbf{2 0 0 0 . 0}$ & 2000.0 & $20.2 \%$ & 404.0 & 404.0 \\
\hline Trim Chemicals & $\begin{array}{c}\text { Target } \\
\text { Addition, grams }\end{array}$ & $\begin{array}{c}\text { Actual } \\
\text { Addition, } \\
\text { grams }\end{array}$ & $\begin{array}{c}\text { Elemental } \\
\text { Solids Factor }\end{array}$ & $\begin{array}{c}\text { Target Elemental } \\
\text { Solids, } \mathrm{g}\end{array}$ & $\begin{array}{c}\text { Actual Elemental } \\
\text { Solids, g }\end{array}$ \\
\hline AgNO3 & $\mathbf{0 . 2 3 5}$ & 0.233 & 0.6349 & 0.149 & 0.148 \\
\hline Cd(NO3)2*4H2O & $\mathbf{1 . 2 2 0}$ & 1.221 & 0.3644 & 0.444 & 0.445 \\
\hline HgO & $\mathbf{5 . 4 5 3}$ & 5.452 & 0.9261 & 5.050 & 5.049 \\
\hline Pd(NO3)2*H2O & $\mathbf{0 . 0 2 1}$ & 0.021 & $0.1527^{\dagger}$ & 0.009 & $0.003^{\dagger}$ \\
\hline Rh(NO3)3*2H2O & $\mathbf{0 . 0 6 8}$ & 0.066 & $0.0493^{\dagger}$ & 0.021 & $0.003^{\dagger}$ \\
\hline RuCl3 & $\mathbf{0 . 1 8 2}$ & 0.182 & $0.4174^{\dagger}$ & 0.089 & $0.076^{\dagger}$ \\
\hline
\end{tabular}

\begin{tabular}{|c|c|c|}
\hline Element & $\begin{array}{c}\text { Target Wt\% } \\
\text { Solids }\end{array}$ & $\begin{array}{c}\text { Actual Wt\% } \\
\text { Solids }\end{array}$ \\
\hline $\mathrm{Ag}$ & $0.04 \%$ & $0.04 \%$ \\
\hline $\mathrm{Cd}$ & $0.11 \%$ & $0.11 \%$ \\
\hline $\mathrm{Hg}$ & $1.25 \%$ & $1.25 \%$ \\
\hline $\mathrm{Pd}$ & $0.0022 \%$ & $0.0008 \%^{\dagger}$ \\
\hline $\mathrm{Rh}$ & $0.0053 \%$ & $0.0008 \%^{\dagger}$ \\
\hline $\mathrm{Ru}$ & $0.022 \%$ & $0.019 \%$ \\
\hline
\end{tabular}

†Values changed from original run plan to reflect noble metal under addition.

Table XL. Trim Chemical Addition for Second Sludge Addition for Run 4V

\begin{tabular}{|c|c|c|c|c|c|}
\hline & $\begin{array}{c}\text { Target } \\
\text { Addition, }\end{array}$ & $\begin{array}{c}\text { Actual } \\
\text { Addition, } \mathrm{g}\end{array}$ & Wt\% Solids & Target Solids, $\mathrm{g}$ & $\begin{array}{c}\text { Actual Solids } \\
\text { added, } \mathrm{g}\end{array}$ \\
\hline Sludge B' & 333.3 & 333.3 & $19.3 \%$ & 64.3 & 64.3 \\
\hline Trim Chemicals & $\begin{array}{c}\text { Target } \\
\text { Addition, grams }\end{array}$ & $\begin{array}{c}\text { Actual } \\
\text { Addition, } \\
\text { grams }\end{array}$ & $\begin{array}{c}\text { Elemental } \\
\text { Solids Factor }\end{array}$ & $\begin{array}{c}\text { Target Elemental } \\
\text { Solids, } \mathbf{g}\end{array}$ & $\begin{array}{c}\text { Actual Elemental } \\
\text { Solids, } \mathbf{g}\end{array}$ \\
\hline AgNO3 & $\mathbf{0 . 0 4 0}$ & 0.039 & 0.6349 & 0.025 & 0.025 \\
\hline Cd(NO3)2*4H2O & $\mathbf{0 . 2 0 3}$ & 0.201 & 0.3644 & 0.074 & 0.073 \\
\hline HgO & $\mathbf{0 . 9 0 9}$ & 0.908 & 0.9261 & 0.842 & 0.841 \\
\hline Pd(NO3)2*H2O & $\mathbf{0 . 0 0 3}$ & 0.003 & $0.1527^{\dagger}$ & 0.001 & $0.00046^{\dagger}$ \\
\hline Rh(NO3)3*2H2O & $\mathbf{0 . 0 1 1}$ & 0.010 & $0.0493^{\dagger}$ & 0.004 & $0.00049^{\dagger}$ \\
\hline RuCl3 & $\mathbf{0 . 0 3 1}$ & $\mathbf{0 . 0 3 0}$ & $0.4174^{\dagger}$ & 0.015 & $0.0125^{\dagger}$ \\
\hline
\end{tabular}

\begin{tabular}{|c|c|c|}
\hline Element & $\begin{array}{c}\text { Target Wt\% } \\
\text { Solids }\end{array}$ & $\begin{array}{c}\text { Actual Wt\% } \\
\text { Solids }\end{array}$ \\
\hline $\mathrm{Ag}$ & $0.04 \%$ & $0.04 \%$ \\
\hline $\mathrm{Cd}$ & $0.11 \%$ & $0.11 \%$ \\
\hline $\mathrm{Hg}$ & $1.30 \%$ & $1.31 \%$ \\
\hline $\mathrm{Pd}$ & $0.0022 \%$ & $0.0007 \%$ \\
\hline $\mathrm{Rh}$ & $0.0053 \%$ & $0.0008 \%$ \\
\hline $\mathrm{Ru}$ & $0.023 \%$ & $0.019 \%$ \\
\hline
\end{tabular}

$\dagger$ Values changed from original run plan to reflect noble metal under addition. 
2) The batching of the materials is designed to produce a glass containing $26 \mathrm{wt} \%$ calcined sludge solids and $74 \mathrm{wt} \%$ frit 200. A batching summary is shown in Table XLI.

3) Calculated acid addition rates, boilup rates, purge rates, antifoam addition, etc. were based on scaling from DWPF settings as shown in Table XLII.

4) Run $1 \mathrm{~V}$ simulates an ideal processing case with high weight percent solids sludge and an elevated acid addition for $170.0 \%$ of stoichiometry with a redox target of $0.2 \mathrm{Fe}^{+2} / \Sigma \mathrm{Fe}$. The higher stoichiometry was chosen since $137.5 \%$ stoichiometry proved inadequate for nitrite destruction in the earlier large batch runs and to help define the minimum acid addition necessary for the large batch operating strategy. This run simulates DWPF most expedient option for increased CPC batch operation. The redox calculation spreadsheets for the Variability Run $1 \mathrm{~V}$ are shown in Table XLIII.

5) Run $4 \mathrm{~V}$ simulates a worst case scenario where sludge solids are high and the SRAT is concentrated down to below the normal 6000 gallon mark. Originally a low acid stoichiometry $(100 \%)$ was going to be used but after the first set of large batch runs it was decided to add a slightly elevated acid quantity ( $150 \%$ stoichiometry) to evaluate nitrite destruction. The redox calculation spreadsheets for the Variability Run 4V are shown in Table XLIV.

6) In both runs ( $1 \mathrm{~V} \& 4 \mathrm{~V})$, the reflux time in the SRAT cycle will be extended until there is evidence of nitrite destruction. The SME cycles may be postponed to a later date.

7) A review, as required by the Conduct of Research and Development was completed and is contained in Appendix B.

8) The experiments should be completed the week of January 18, 1999.

Table XLI. Batching Summary for Variability Runs 1V and 4V

\begin{tabular}{|l|l|l|}
\hline Batching Summary & Run IV & Run 4V \\
\hline Sludge \& Heel Mass & $2820.4 \mathrm{~g}$ & $2722.9 \mathrm{~g}$ \\
\hline Nitric Acid Volume, $\mathrm{ml}$ & $59.61 \mathrm{ml}$ & $52.37 \mathrm{ml}$ \\
\hline Formic Acid Volume, $\mathrm{ml}$ & $128.69 \mathrm{ml}$ & $117.14 \mathrm{ml}$ \\
\hline SRAT Product Sample, $\mathrm{ml}$ & 125 & 125 \\
\hline Frit 200 Addition \#1, g & $559.04 \mathrm{~g}$ & $540.04 \mathrm{~g}$ \\
\hline SME Water Addition \#1, g & $1026.83 \mathrm{~g}$ & $991.93 \mathrm{~g}$ \\
\hline SME 90 wt\% Formic Acid Addition \#1, g & $11.39 \mathrm{~g}$ & $11.00 \mathrm{~g}$ \\
\hline Frit 200 Addition \#2, g & $559.04 \mathrm{~g}$ & $540.04 \mathrm{~g}$ \\
\hline SME Water Addition \#2; g & $1026.83 \mathrm{~g}$ & $991.93 \mathrm{~g}$ \\
\hline SME 90 wt\% Formic Acid Addition \#2, g & $11.39 \mathrm{~g}$ & $11.00 \mathrm{~g}$ \\
\hline SRAT Air Purge, scc/min & 466.5 & 466.5 \\
\hline SRAT Helium purge, scc/min & 2.34 & 2.34 \\
\hline SME Air Purge, scc/min & 163.8 & 163.8 \\
\hline SME Helium purge, scc/min & 0.82 & 0.82 \\
\hline
\end{tabular}

'Actual SRAT Gas Purge equivalent to this Air purge plus the Helium Purge. 
Table XLII. Scaling Calculations for Large Batch Variability Runs IV and 4V

\begin{tabular}{|c|c|c|c|c|c|c|}
\hline & DWPF & TNX 1V & Time & DWPF & TNX 4V & Time \\
\hline Scale factor & & $11,355(13172)^{\dagger}$ & & & \multicolumn{2}{|c|}{$11,355(13172)^{\dagger}$} \\
\hline Sludge Added Volume & $7,000 \mathrm{gal}$ & $2011 \mathrm{ml}$ & & $7,000 \mathrm{gal}$ & $2011 \mathrm{ml}$ & \\
\hline Sludge Heel Volume & $1,500 \mathrm{gal}$ & $431 \mathrm{ml}$ & & $1,200 \mathrm{gal}$ & $345 \mathrm{ml}$ & \\
\hline Sludge Added Density & 1.16 & 1.16 & & 1.16 & 1.16 & \\
\hline Sludge Heel Density & 1.13 & 1.13 & & 1.13 & 1.13 & \\
\hline Sludge Added Mass & $30736 \mathrm{~kg}$ & $2333.3 \mathrm{~g}$ & & $30736 \mathrm{~kg}$ & $2333.3 \mathrm{~g}$ & \\
\hline Sludge Heel Mass & $6416 \mathrm{~kg}$ & $487.1 \mathrm{~g}$ & & $5133 \mathrm{~kg}$ & $389.6 \mathrm{~g}$ & \\
\hline SRAT Added Water & $1,000 \mathrm{gal}$ & $287.4 \mathrm{ml}$ & $2.4 \mathrm{hrs}$ & $1,000 \mathrm{gal}$ & $287.4 \mathrm{ml}$ & $2.3 \mathrm{hrs}$ \\
\hline SRAT purge air ${ }^{\ddagger}$ & $188 \mathrm{scfm}$ & $466.5 \mathrm{scc} / \mathrm{min}$ & & $188 \mathrm{scfm}$ & $\begin{array}{c}466.5 \\
\mathrm{scc} / \mathrm{min}\end{array}$ & \\
\hline SRAT He purge & $0.50 \mathrm{vol} \%$ & $2.34 \mathrm{scc} / \mathrm{min}$ & & 0.50 vol $\%$ & $\begin{array}{c}2.34 \\
\mathrm{scc} / \mathrm{min}\end{array}$ & \\
\hline SME purge air ${ }^{\ddagger}$ & $66 \mathrm{scfm}$ & $163.8 \mathrm{scc} / \mathrm{min}$ & & $66 \mathrm{scfm}$ & $\begin{array}{c}163.8 \\
\mathrm{scc} / \mathrm{min}\end{array}$ & \\
\hline SME He purge & $0.50 \mathrm{vol} \%$ & $0.82 \mathrm{scc} / \mathrm{min}$ & & 0.50 vol \% & $\begin{array}{c}0.82 \\
\mathrm{scc} / \mathrm{min}\end{array}$ & \\
\hline & & & & & & \\
\hline Antifoam (100 ppm in Total Sludge) & $8.19 \mathrm{lbs}$ & $0.23 \mathrm{~g}$ & & $7.91 \mathrm{lbs}$ & $0.23 \mathrm{~g}$ & \\
\hline Antifoam Solution (20 to 1 solution) & $163.81 \mathrm{lbs}$ & $4.67 \mathrm{~g}$ & & $158.15 \mathrm{lbs}$ & $4.67 \mathrm{~g}$ & \\
\hline Elemental $\mathrm{Hg}$ to Reduce & & & & & & \\
\hline nitric acid feedrate & $2 \mathrm{gpm}$ & $0.669 \mathrm{ml} / \mathrm{min}$ & $1.4 \mathrm{hrs}$ & $2 \mathrm{gpm}$ & $\begin{array}{c}0.669 \\
\mathrm{ml} / \mathrm{min}\end{array}$ & $1.3 \mathrm{hrs}$ \\
\hline formic acid feedrate & $2 \mathrm{gpm}$ & $0.687 \mathrm{ml} / \mathrm{min}$ & $3.2 \mathrm{hrs}$ & $2 \mathrm{gpm}$ & $\begin{array}{c}0.687 \\
\mathrm{ml} / \mathrm{min}\end{array}$ & $2.9 \mathrm{hrs}$ \\
\hline boilup rate & $5,000 \mathrm{lb} / \mathrm{hr}$ & $3.33 \mathrm{~g} / \mathrm{min}$ & & $5,000 \mathrm{lb} / \mathrm{hr}$ & $3.33 \mathrm{~g} / \mathrm{min}$ & \\
\hline Formic Molarity & $23.55 \mathrm{M}$ & $22.85 \mathrm{M}$ & & $23.55 \mathrm{M}$ & $22.85 \mathrm{M}$ & \\
\hline Nitric Molarity & $10.35 \mathrm{M}$ & $10.32 \mathrm{M}$ & & $10.35 \mathrm{M}$ & $10.32 \mathrm{M}$ & \\
\hline Formic Volume & $374.6 \mathrm{gal}$ & $128.69 \mathrm{ml}$ & & $340.9 \mathrm{gal}$ & $117.14 \mathrm{ml}$ & \\
\hline Formic Mass & & $155.00 \mathrm{~g}$ & & & $141.09 \mathrm{~g}$ & \\
\hline Nitric Volume & $178.3 \mathrm{gal}$ & $59.61 \mathrm{ml}$ & & $156.7 \mathrm{gal}$ & $52.37 \mathrm{ml}$ & \\
\hline Nitric Mass & & $78.00 \mathrm{~g}$ & & & $68.53 \mathrm{~g}$ & \\
\hline formic feed time & $187.3 \mathrm{~min}$ & $187.3 \mathrm{~min}$ & & $170.5 \mathrm{~min}$ & $170.5 \mathrm{~min}$ & \\
\hline Nitric feed time & $89.2 \mathrm{~min}$ & $89.2 \mathrm{~min}$ & & $78.3 \mathrm{~min}$ & $78.3 \mathrm{~min}$ & \\
\hline Total Vol & & $2918.15 \mathrm{ml}$ & & & $2813.16 \mathrm{ml}$ & \\
\hline Frit Volume, gallons & $3,727 \mathrm{gal}$ & $1242.317 \mathrm{~g}$ & & $3,600 \mathrm{gal}$ & $1200.085 \mathrm{~g}$ & \\
\hline Frit Density & 1.5 & & & 1.5 & & \\
\hline Frit wt \% solids & $60 \%$ & & & $60 \%$ & & \\
\hline Frit Solids & $27,989.9 \mathrm{lbs}$ & $1118.085 \mathrm{~g}$ & & $27,038.4 \mathrm{lbs}$ & $1080.076 \mathrm{~g}$ & \\
\hline Formic Acid & $513.1 \mathrm{lbs}$ & $20.498 \mathrm{~g}$ & & $495.7 \mathrm{lbs}$ & $19.801 \mathrm{~g}$ & \\
\hline Water & $33,696.8 \mathrm{lbs}$ & $1346.051 \mathrm{~g}$ & & $32,551.3 \mathrm{lbs}$ & $1300.292 \mathrm{~g}$ & \\
\hline Transfer Water & $17,771.4 \mathrm{lbs}$ & $709.895 \mathrm{~g}$ & & $17,167.3 \mathrm{lbs}$ & $685.763 \mathrm{~g}$ & \\
\hline Total Water & $51,468.2 \mathrm{lbs}$ & $2055.946 \mathrm{~g}$ & & $49,718.5 \mathrm{lbs}$ & $1986.055 \mathrm{~g}$ & \\
\hline Total & $79,971.3 \mathrm{lbs}$ & $3194.530 \mathrm{~g}$ & & $77,252.7 \mathrm{lbs}$ & $3085.933 \mathrm{~g}$ & \\
\hline
\end{tabular}


Table XLII. Scaling Calculations for Large Batch Variability Runs $1 \mathrm{~V}$ and $4 \mathrm{~V}$ Continued

\begin{tabular}{|l|c|c|c|c|c|c||}
\hline & DWPF & TNX 1V & Time & DWPF & TNX 4V & Time \\
\hline frit 200 & $27,989.9 \mathrm{lbs}$ & $1118.085 \mathrm{~g}$ & & $27,038.4 \mathrm{lbs}$ & $1080.076 \mathrm{~g}$ & \\
\hline $90 \mathrm{wt} \%$ formic acid & $570.2 \mathrm{lbs}$ & $22.776 \mathrm{~g}$ & & $550: 8 \mathrm{lbs}$ & $22.002 \mathrm{~g}$ & \\
\hline water & $51,411.1 \mathrm{lbs}$ & $2053.668 \mathrm{~g}$ & & $49,663.4 \mathrm{lbs}$ & $1983.855 \mathrm{~g}$ & \\
\hline Total & $79,971.3 \mathrm{lbs}$ & $3194.530 \mathrm{~g}$ & & $77,252.7 \mathrm{lbs}$ & $3085.933 \mathrm{~g}$ & \\
\hline & & & & & & \\
\hline frit 200 Addition 1 & $13,995.0 \mathrm{lbs}$ & $559.043 \mathrm{~g}$ & & $13,519.2 \mathrm{lbs}$ & $540.038 \mathrm{~g}$ & \\
\hline $90 \mathrm{wt} \%$ formic addition 1 & $285.1 \mathrm{lbs}$ & $11.388 \mathrm{~g}$ & & $275.4 \mathrm{lbs}$ & $11.001 \mathrm{~g}$ & \\
\hline water addition 1 & $25,705.6 \mathrm{lbs}$ & $1026.834 \mathrm{~g}$ & $5.1 \mathrm{hrs}$ & $24,831.7 \mathrm{lbs}$ & $991.927 \mathrm{~g}$ & $5.0 \mathrm{hrs}$ \\
\hline frit 200 Addition 2 & $13,995.0 \mathrm{lbs}$ & $559.043 \mathrm{~g}$ & & $13,519.2 \mathrm{lbs}$ & $540.038 \mathrm{~g}$ & \\
\hline 90 wt \% formic addition 2 & $285.1 \mathrm{lbs}$ & $11.388 \mathrm{~g}$ & & $275.4 \mathrm{lbs}$ & $11.001 \mathrm{~g}$ & \\
\hline water addition 2 & $25,705.6 \mathrm{lbs}$ & $1026.834 \mathrm{~g}$ & $5.1 \mathrm{hrs}$ & $24,831.7 \mathrm{lbs}$ & $991.927 \mathrm{~g}$ & $5.0 \mathrm{hrs}$ \\
\hline
\end{tabular}

Table XLIII. Large Batch Variability Run 1V Redox Calculation

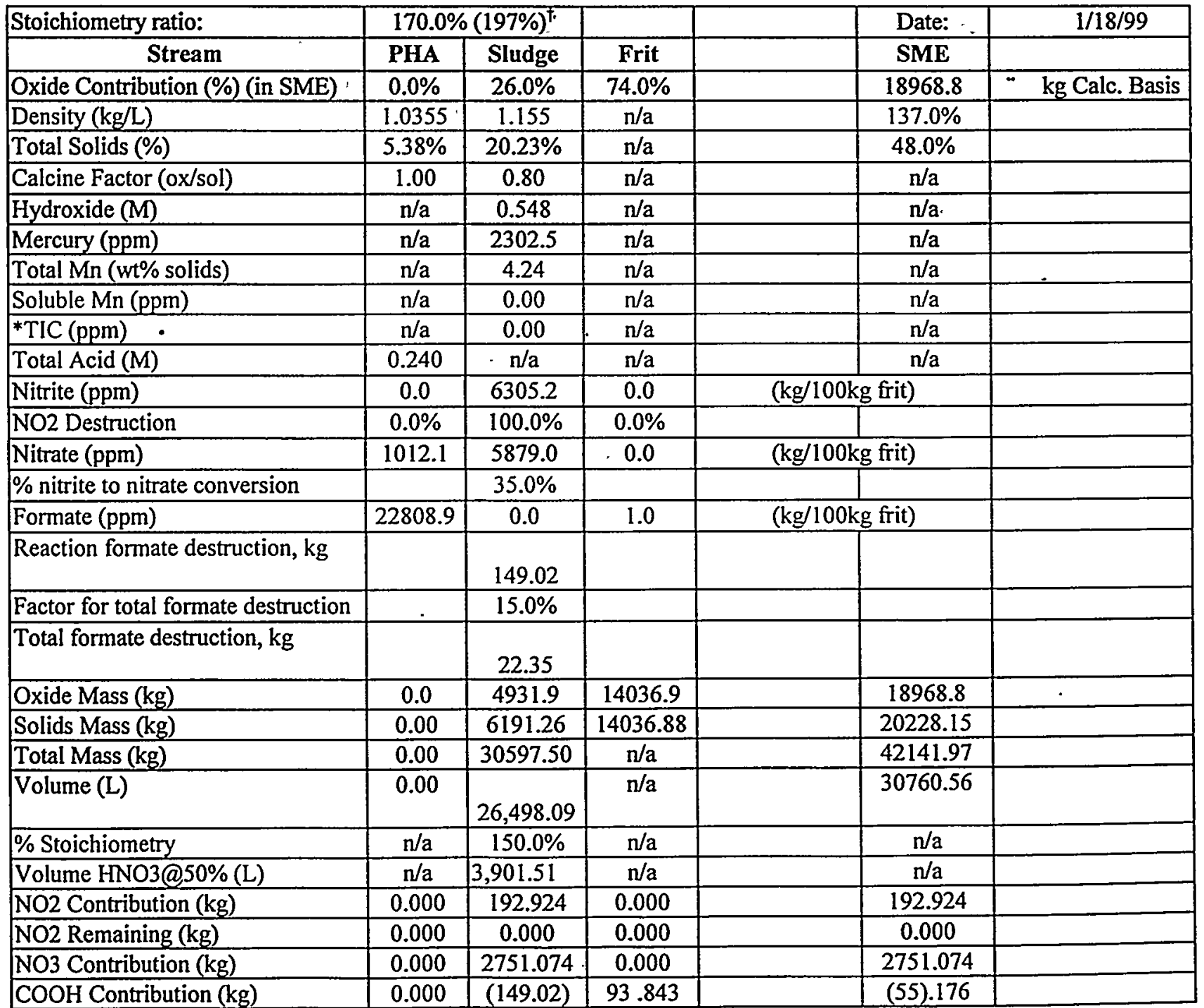


Table XLIII. Large Batch Variability Run 1V Redox Calculation Continued

\begin{tabular}{|c|c|c|c|c|c|c|}
\hline Stoichiometry ratio: & $170.0 \%$ & $(197 \%)^{\dagger}$ & & & Date: & $1 / 18 / 99$ \\
\hline Stream & \begin{tabular}{l|l|} 
PHA & \\
\end{tabular} & Sludge & Frit & & SME & \\
\hline NO2 (Molar@45\%) & & & & & 0.000 & \\
\hline NO3 (Molar@45\%) & & & & & 1.881 & \\
\hline $\mathrm{COOH}$ (Molar@45\%) & & & & & -0.052 & \\
\hline Predicted $\mathrm{Fe}(\mathrm{II}) / \Sigma \mathrm{Fe}$ & & & 0.09 & $\leq$ & BDL@0.03 & 0.1 \\
\hline Volume HCOOH@90\% (L) & & & 4875.67 & & 4534.09 & 4932.67 \\
\hline$\%$ Stoichiometry & $n / a$ & $170.0 \%$ & $\mathrm{n} / \mathrm{a}$ & & $\mathrm{n} / \mathrm{a}$ & \\
\hline Volume HCOOH@90\% (L) & $n / a$ & $1,714.50$ & $\mathrm{n} / \mathrm{a}$ & & $\mathrm{n} / \mathrm{a}$ & \\
\hline NO2 Contribution $(\mathrm{kg})$ & 0.000 & 192.924 & 0.000 & & 192.924 & \\
\hline NO2 Remaining (kg) & 0.000 & 0.000 & 0.000 & & 0.000 & \\
\hline NO3 Contribution (kg) & 0.000 & 247.406 & 0.000 & & 247.406 & \\
\hline COOH Contribution $(\mathrm{kg})$ & 0.000 & 1795.398 & 93.843 & & 1889.241 & \\
\hline NO2 (Molar@45\%) & & & & & 0.000 & \\
\hline NO3 (Molar@45\%) & & & & & 0.169 & \\
\hline COOH (Molar@45\%) & & & & & 1.78 & \\
\hline Predicted $\mathrm{Fe}(\mathrm{II}) / \Sigma \mathrm{Fe}$ & & & 0.09 & $\leq$ & 0.543 & 0.1 \\
\hline Volume HNO3@50\% (L) & & & 1567.01 & & & 1523.92 \\
\hline mol\% Nitric & $n / a$. & $17.3 \%$ & $\mathrm{n} / \mathrm{a}$ & & $n / \mathbf{a}$ & \\
\hline Volume HCOOH@90\% (L) & $n / a$. & $1,417.89$ & $\mathrm{n} / \mathrm{a}$ & & $\mathrm{n} / \mathrm{a}$ & \\
\hline Volume HNO3@50\% (L) & & 674.96 & & & & \\
\hline NO2 Contribution $(\mathrm{kg})$ & 0.000 & 192.924 & 0.000 & & 192.924 & \\
\hline NO2 Remaining $(\mathrm{kg})$ & 0.000 & 0.000 & 0.000 & & 0.000 & \\
\hline NO3 Contribution (kg) & 0.000 & 680.541 & 0.000 & & 680.541 & \\
\hline $\mathrm{COOH}$ Contribution (kg) & 0.000 & 1354.260 & 0.000 & & 1354.260 & \\
\hline NO2 (Molar@45\%) & & & & & 0.000 & \\
\hline NO3 (Molar@45\%) & & . & & & 0.465 & - \\
\hline COOH (Molar@45\%) & & & & & 1.276 & \\
\hline Predicted $\mathrm{Fe}(\mathrm{II}) / \Sigma \mathrm{Fe}$ & & & 0.09 & $\leq$ & $0.200(0.221)^{f}$ & -0.1 \\
\hline
\end{tabular}

${ }^{\dagger}$ Value in parentheses represents corrected value due to scale factor error. $\mathrm{kgb} 9 / 16 / 96$ 
Table XLIV. Large Batch Variability Run 4V Redox Calculation

\begin{tabular}{|c|c|c|c|c|c|c|}
\hline Stoichiometry ratio & \multicolumn{2}{|c|}{$150.0 \%(175 \%)^{\dagger}$} & & Date: & $1 / 18 / 99$ & \\
\hline Stream & PHA & Sludge & Frit I & & SME & \\
\hline Oxide Contribution (\%) (in SME) & $0.0 \%$ & $26.0 \%$ & $74.0 \%$ & & 19102.8 & " kg Calc. Basis \\
\hline Density $(\mathrm{kg} / \mathrm{L})$ & 1.0355 & 1.156 & $\mathrm{n} / \mathrm{a}$ & & $137.0 \%$ & \\
\hline Total Solids (\%) & $5.38 \%$ & $20.23 \%$ & $\mathrm{n} / \mathrm{a}$ & & $48.0 \%$ & \\
\hline Calcine Factor (ox/sol) & 1.00 & 0.80 & $\overline{n / a}$ & & $\mathrm{n} / \mathrm{a}$ & \\
\hline Hydroxide (M) & $\mathrm{n} / \mathrm{a}$ & 0.566 & $n / \mathbf{a}$ & & $n / a$ & \\
\hline Mercury (ppm) & $\mathrm{n} / \mathrm{a}$ & 2348.1 & $\overline{n / a}$ & & $n / a$ & \\
\hline Total Mn (wt\% solids) & $\mathrm{n} / \mathrm{a}$ & 4.24 & $n / a$ & & $\mathrm{n} / \mathrm{a}$ & \\
\hline Soluble Mn (ppm) & $\mathrm{n} / \mathrm{a}$ & 0.00 & $\mathrm{n} / \mathbf{a}$ & & $\bar{n} / \mathbf{a}$ & \\
\hline *TIC (ppm) & $\mathrm{n} / \mathrm{a}$ & 0.00 & $n / a$ & & $n / a$ & $\cdot$ \\
\hline Total Acid (M) & 0.240 & $\mathrm{n} / \mathrm{a}$ & $\mathrm{n} / \mathrm{a}$ & & $\mathrm{n} / \mathrm{a}$ & \\
\hline Nitrite (ppm) & 0.0 & 6520.4 & 0.0 & \multicolumn{2}{|c|}{$1(\mathrm{~kg} / 100 \mathrm{~kg}$ frit $)$} & \\
\hline NO2 Destruction & $0.0 \%$ & $100.0 \%$ & $0.0 \%$ & + & & \\
\hline Nitrate (ppm) & 1012.1 & 5431.4 & 0.0 & \multicolumn{2}{|c|}{$(\mathrm{kg} / 100 \mathrm{~kg}$ frit) } & \\
\hline$\%$ nitrite to nitrate conversion & & $35.0 \%$ & & & & \\
\hline Formate (ppm) & 22808.9 & 0.0 & 1.0 & \multicolumn{2}{|c|}{ (kg/100kg frit) } & \\
\hline Reaction formate destruction, $\mathrm{kg}$ & & 151.08 & & & & \\
\hline Factor for total formate destruction & & $15.0 \%$ & & & & . \\
\hline Total formate destruction, $\mathrm{kg}$ & & 22.66 & & & & \\
\hline Oxide Mass (kg) & 0.0 & 4966.7 & 14136.1 & & 19102.8 & \\
\hline Solids Mass (kg) & 0.00 & 6194.30 & 14136.06 & & 20330.36 & \\
\hline Total Mass (kg) & 0.00 & 30621.45 & $n / a$ & & 42354.92 & \\
\hline Volume (L) & 0.00 & $26,498.09$ & $\mathrm{n} / \mathrm{a}$ & & 30916.00 & \\
\hline$\%$ Stoichiometry & $\mathrm{n} / \mathrm{a}$ & $150.0 \%$ & $\mathrm{n} / \mathbf{a}$ & & $\mathrm{n} / \mathrm{a}$ & \\
\hline Volume HNO3@50\% (L) & $\mathbf{n} / \mathbf{a}$ & $3,529.96$ & $\mathrm{n} / \mathrm{a}$ & & $\mathbf{n} / \mathbf{a}$ & \\
\hline NO2 Contribution $(\mathrm{kg})$ & 0.000 & 199.664 & 0.000 & & 199.664 & \\
\hline NO2 Remaining (kg) & 0.000 & 0.000 & 0.000 & & 0.000 & \\
\hline NO3 Contribution $(\mathrm{kg})$ & 0.000 & 2501.439 & 0.000 & & 2501.439 & \\
\hline COOH Contribution (kg) & 0.000 & $(151.08)$ & 93.843 & & $(57) .236$ & \\
\hline NO2 (Molar@45\%) & & & & & 0.000 & \\
\hline NO3 (Molar@45\%) & & & & & 1.711 & \\
\hline COOH (Molar@45\%) & & & & & -0.054 & \\
\hline Predicted $\mathrm{Fe}(\mathrm{II}) / \sum \mathrm{Fe}$ & & & 0.09 & $\leq$ & BDL@0.03 & 0.1 \\
\hline Volume HCOOH@90\% (L) & & & 4366.21 & & 4023.48 & 4423.40 \\
\hline$\%$ Stoichiometry & $\mathrm{n} / \mathrm{a}$ & $150.0 \%$ & $\mathrm{n} / \mathrm{a}$ & & $\mathrm{n} / \mathrm{a}$ & \\
\hline Volume HCOOH@90\% (L) & $\mathrm{n} / \mathrm{a}$ & $1,551.23$ & $\mathrm{n} / \mathrm{a}$ & & $\mathrm{n} / \mathrm{a}$ & \\
\hline NO2 Contribution $(\mathrm{kg})$ & 0.000 & 199.664 & 0.000 & & 199.664 & \\
\hline NO2 Remaining (kg) & 0.000 & 0.000 & 0.000 & & 0.000 & \\
\hline NO3 Contribution (kg) & 0.000 & 236.200 & 0.000 & & 236.200 & \\
\hline $\mathrm{COOH}$ Contribution (kg) & 0.000 & 1621.981 & 93.843 & & 1715.824 & \\
\hline
\end{tabular}


Table XLIV. Large Batch Variability Run 4V Redox Calculation Continued

\begin{tabular}{|l|c|c|c|c|c|c|}
\hline \multicolumn{1}{|c|}{ Stoichiometry ratio: } & \multicolumn{2}{c|}{$150.0 \%(175 \%)^{\dagger}$} & & Date: & $1 / 18 / 99$ & \\
\hline Stream & PHA & Sludge & Frit & & SME & \\
\hline NO2 (Molar@45\%) & & & & & 0.000 & \\
\hline NO3 (Molar@45\%) & & & & & 0.162 & \\
\hline COOH (Molar@45\%) & & & & & 1.616 & \\
\hline Predicted Fe(II)//Fe & & & 0.09 & $\leq$ & 0.509 & $\leq$ \\
\hline Volume HNO3@50\%(L) & & & 1462.28 & & & 0.1 \\
\hline mol\% Nitric & $\mathrm{n} / \mathrm{a}$ & $16.8 \%$ & $\mathrm{n} / \mathrm{a}$ & & $\mathrm{n} / \mathrm{a}$ & \\
\hline Volume HCOOH@90\%(L) & $\mathrm{n} / \mathrm{a}$ & $1,290.62$ & $\mathrm{n} / \mathrm{a}$ & & $\mathrm{n} / \mathrm{a}$ & \\
\hline Volume HNO3@50\% (L) & & 593.03 & & & & \\
\hline NO2 Contribution (kg) & 0.000 & 199.664 & 0.000 & & 199.664 & \\
\hline NO2 Remaining (kg) & 0.000 & 0.000 & 0.000 & & 0.000 & \\
\hline NO3 Contribution (kg) & 0.000 & 616.760 & 0.000 & & 616.760 & \\
\hline COOH Contribution (kg) & 0.000 & 1217.264 & 0.000 & & 1217.264 & \\
\hline NO2 (Molar@45\%) & & & & & 0.000 & \\
\hline NO3 (Molar@45\%) & & & & & 0.422 & \\
\hline COOH (Molar@45\%) & & & & & 1.147 & \\
\hline Predicted Fe(II)/2Fe & & & 0.09 & $\leq$ & $0.200(0.221)^{\dagger}$ & $\leq$ \\
\hline
\end{tabular}

${ }^{\mathrm{t}}$ Value in parentheses represents corrected value due to scale factor error. 
Westinghouse Savannah River Company Savannah River Technology Center
APPENDIX A-4: Runs IV/4V

WSRC-TR-99-00111, Rev. 0

Page 75 of 111

Date: $1 / 19 / 99$

\section{Run \# $1 \mathrm{~V} \& 4 \mathrm{~V}$}

\section{PREREQUISITES}

1. 5 Signed TAR requesting work.

2. Issued Testing scope and task assignment.

3. 4 Analyze sludge for density, total base ( $\mathrm{pH} 5.5)$, nitrate, manganese, nitrite, density, solids.

4. Calibrate GC. Calibrate for nitrogen, oxygen, $\mathrm{N} 2 \mathrm{O}$, hydrogen, and carbon dioxide.

5. 4 Prepare sufficient $90 \%$ formic acid and $50 \%$ nitric acid.

6. 4 Prepare sufficient antifoam solution or make sure sufficient solution is available.

7. 7 Calculate batching and scaling for experiment based on DWPF parameters.

8. 4 Calculate redox for experiment based on DWPF parameters.

9. Setup 2 experimental rigs per sketch below.

10. Complete leak checks and water runs.

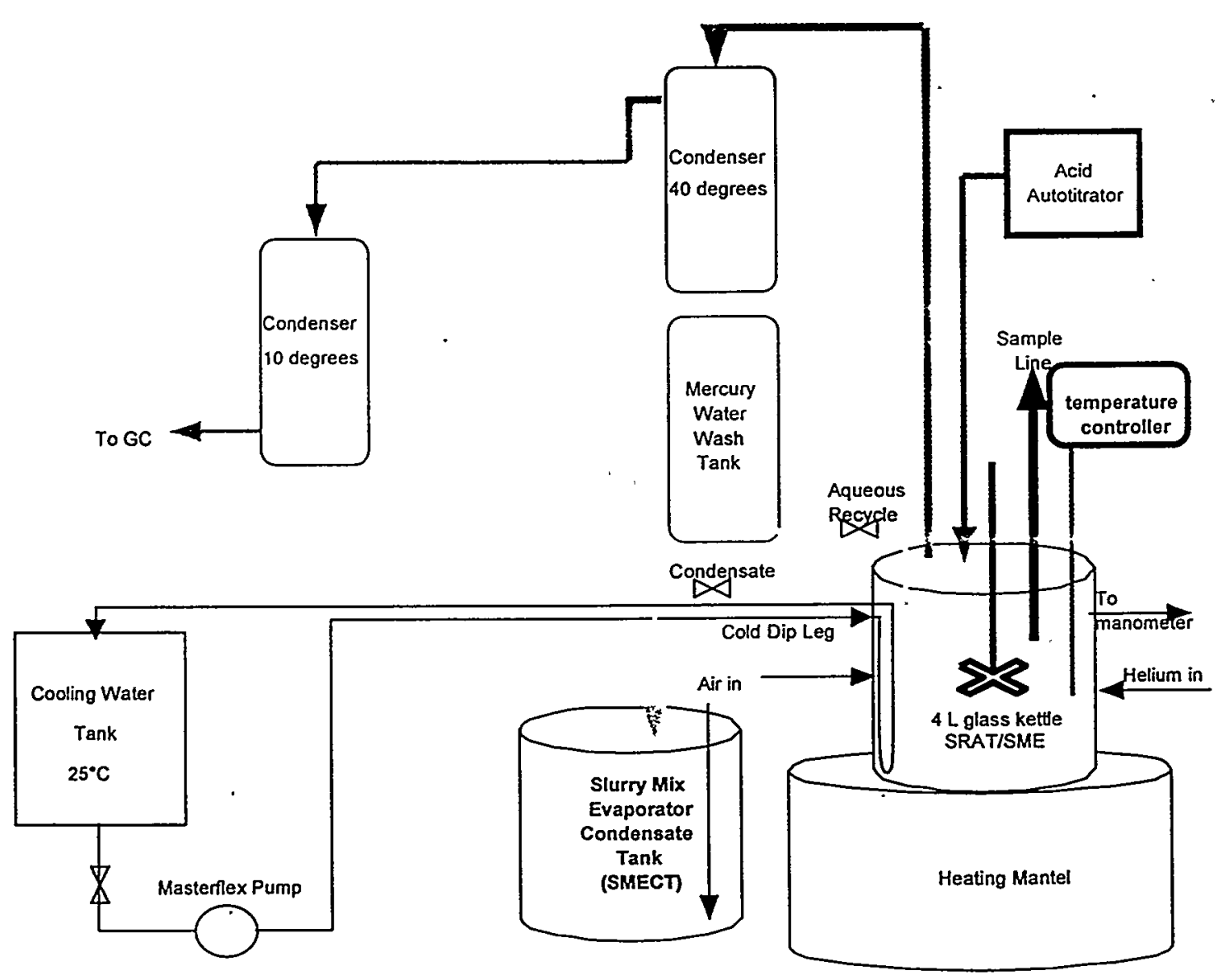


Date: $1 / 20 / 99$

\section{PREPARATION FOR SRAT CYCLE}

Note: Zo not insulate kettle until acid addition is complete

1. HAdd $2000 \mathrm{~g}$ of Sludge $\mathrm{B}^{\prime}$ to kettle using 2-liter transfer bottle or beaker.

2. JAdd 487.1 $\mathrm{g}$ of SRAT Heel $\mathrm{A}^{\prime}$ to kettle using 2-liter transfer bottle or beaker.

3. Turn on kettle agitator. Setpoint $=200 \mathrm{rpm}$. Mark Sludge Level in Kettle as De-water Level for fater de-watering and concentration.

4. Add first batch of trim chemicals (from Table XXXVII) directly to the kettle.

5. $\nabla_{\text {Transfer }} 287.4 \mathrm{ml}$ of distilled water to the kettle (use to rinse all containers used for adding sludge, noble metals, mercury, etc.).

6. Calibrate $\mathrm{pH}$ probe with $\mathrm{pH} 4$ and 10 buffer. Record measured $\mathrm{pH}$ of $\mathrm{pH} 7$ buffer $\_.033$.

7. Install pH probe in kettle. Record initial pH of sludge 11.623 .

8. Turn on the air purge to kettle at $\mathbf{1 0 0 . 0 ~ s c c m}$. Connect the outlet flowmeter to perform the leak check. The outlet flow should be $\mathbf{9 0 - 1 1 0 ~ s c c m}$. If it is not, tighten all connections until the system is leak

9. Disconnect outlet flowmeter.

10. 4 Set the air flow to kettle at $466.5 \mathrm{sccm}$. Set the He flow to $2.34 \mathrm{sccm}$.

11. / Turn on cooling water to SRAT condenser. Setpoint $=40^{\circ} \mathrm{C}$.

12. Turn on cooling water to Chilled (FAVC) condenser. Setpoint $=10^{\circ} \mathrm{C}$.

13. Make sure the GC computer has enough memory space for the run (at least 40 Mbyte).

14. Set the GC computer time equal to the clock time. Record the time in the log book.

15. Install the calibration gas cylinder to the $\mathrm{GC}$ and let the $\mathrm{GC}$ run five times. If at the end of five runs the $\mathrm{GC}$ reading is within $10 \%$ of the gas composition in the cylinder, print the calibration check results and write down "pre-cal check and run number" on the printout. Otherwise, select "Calibration" "Level 1" "OK" to calibrate the GC five times. At the end of five runs the GC reading should be within $10 \%$ of the gas composition in the cylinder. If it is not, contact the engineer. Print the calibration check results and write down "pre-cal check and run number" on the printout.

16. Wtart the GC for this run beginning with baseline reading for a few minutes. Write down the GC time, filename etc. in the logbook. Record the baseline data on the data sheet. 
Westinghouse Savannah River Company Savannah River Technology Center

Run \#

1V

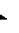

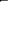

APPENDIX A-4: Runs IV/4V

A-A: Runs IVIAV
WSRC-TR-99-00111, Rev. 0

Page 77 of 111

Date: $1 / 20 / 99$

\section{SRAT CYCLE}

1. Add $2.3 \mathrm{~g} 1: 10$ antifoam solution and $2.3 \mathrm{~g}$ water directly to the kettle (100-ppm antifoam).

2. Start heating up the kettle with the Therm-O-Watch (yellow box) temperature controller. Turn on its power switch, press the [SEL] key for 3 seconds until display shows "roFF". Press the [^] key until display shows "rrUn" then press and hold the [SEL] key until the normal display appears. The Therm-O-Watch will ramp up to $93^{\circ} \mathrm{C}$ and hold at $93^{\circ} \mathrm{C}$. Record the run data pvery 20 minutes on the data sheet.

3. Hook the heating mantle to the Cole-Parmer (gray box) temperature controller, and switch on the Cole-Parmer unit. Bring the kettle contents to boiling.

4. If slurry begins to foam over at any time, switch off heating and turn on the cooling coil water pump to bring the temperature down rapidly. Add antifoam solution as shown in Step 1. Then switch off the cooling coil water pump and slowly heat up the kettle again to the point of boiling.

5. Dewater until remove $287.4 \mathrm{~g}$ of water (kettle volume should be close to De-water Level marked in Step 3 of PREPARATION FOR SRAT CYCLE). Should take about 1 hour and $\beta 0$ minutes.

6. When dewatering is complete, turn off the heat to kettle, turn on water to cooling coil, and pool the kettle to sub-boiling $\left(90^{\circ} \mathrm{C}\right)$.

7. Add 333.3 $\mathrm{g}$ of Sludge $\mathrm{B}^{\prime}$ to the kettle using 2-liter transfer bottle or beaker.

8. Add second batch of trim chemicals (from Table XXXVIII) directly to the kettle.

9. Transfer $50 \mathrm{ml}$ of distilled water to the kettle (use to rinse all containers used for adding

pludge, noble metals, mercury, etc.).

10. Allow slurry to cool to $50^{\circ} \mathrm{C}$, monitoring torque every 20 minutes.

11. Pull $10 \mathrm{ml}$ sample for nitrate, nitrite, and formate analysis. Weigh and record in lab book. Add $1 \mathrm{ml}$ of $1 \mathrm{~N} \mathrm{NaOH}$ solution, reweigh, and record in lab book. Label the sample LB SRAT $1 V^{*}-0 \mathrm{~N}$.

12. Start heating up the kettle with the Therm-O-Watch (yellow box) temperature controller. Press the [SEL] key for 3 seconds until display shows "roFF". If display shows "rrUn", press the $\left[^{\wedge}\right]$ or $[\vee]$ key until display shows "roFF". Press the $[\wedge]$ or $[\vee]$ key until display shows "rrUn" then press and hold the [SEL] key until the normal display appears. The Therm-OWatch will ramp up to $93^{\circ} \mathrm{C}$ and hold at $93^{\circ} \mathrm{C}$. Record the run data every 20 minutes on the data sheet.

13. Once at $93^{\circ} \mathrm{C}$, add $59.61 \mathrm{mI}$ of $50-\mathrm{wt} \%$ nitric acid at $0.669 \mathrm{~mL} / \mathrm{min}$ (reference Table XLII) to the kettle. Should take about 1 hour and 30 minutes.

14. Add $128.69 \mathrm{ml}$ of $90-\mathrm{wt} \%$ formic acid at $0.687 \mathrm{ml} / \mathrm{min}$ (reference Table XLII) to the kettle. should take about 3 hours and 15 minutes.

15. Add $2.3 \mathrm{~g} \mathrm{1:10}$ antifoam solution and $2.3 \mathrm{~g}$ water directly to the kettle (100 ppm antifoam).

16. Hook the heating mantle to the Cole-Parmer (gray box) temperature controller and switch on the Cole-Parmer unit. Bring the kettle contents to boiling. 
Westinghouse Savannah River Company Savannah River Technology Center
APPENDIX A-4: Runs 1V/4V

WSRC-TR-99-00111, Rev. 0

Page 78 of 111

Run \# 1V

SRAT CYCLE (continued)

17. $\forall$ Dewater until collect $927 \mathrm{~g}$ of $\mathrm{H} 2 \mathrm{O}$ in the SMECT leaving approximately $1.7 \mathrm{~L}$ in the kettle. Should take about 4.6 hours.

18. Pull $10 \mathrm{ml}$ sample for nitrate, nitrite, and formate analysis. Weigh and record in lab book. Add $1 \mathrm{ml}$ of $1 \mathrm{~N} \mathrm{NaOH}$ solution, reweigh, and record in lab book. Label LB SRAT 1V*_ 19. $\nabla_{\text {Add }}^{\text {20. }}$ $\mathrm{g} / \mathrm{min}$ boil-up taking $10 \mathrm{ml}$ sample for nitrate, nitrite, and formate analysis every 2 hours and one at the end. Continue refluxing until there is evidence of nitrite destruction (hydrogen release) and the hydrogen has reached its peak. Then turn off the heat to cool the kettle to sub-boiling. Weigh samples and record in lab book. Add $1 \mathrm{ml}$ of $1 \mathrm{~N} \mathrm{NaOH}$ solution to each sample, reweigh, and record in lab book. Label as LB SRAT 1V*-2N, 4N, $5 \mathrm{~N}, 8 \mathrm{~N}, 10 \mathrm{~N}$, etc. (18.5 hours total)

21. $\forall$ Pull a $125 \mathrm{ml}$ sample from the kettle, record the weight on the run sheet. Label as LB SRAT $1 V^{*}$ and send to lab for analyses.

22. $\nabla$ Pull a $\underline{125} \mathrm{ml}$ sample from the kettle, record the weight on the run sheet. Label as LB SRAT 23. $1 V^{*}$ Rheology and send to lab for Rheology.

23. $\triangle$ Remove Sampler and insert rubber stopper in port. (Weigh and record at $157.24 \mathrm{~g}$ ) 
Westinghouse Savannah River Company

Savannah River Technology Center

Run \# 1V
APPENDIX A-4: Runs IV/4V

WSRC-TR-99-00111, Rev. 0

Page 79 of 111

Date: $1 / 21 / 99$

\section{SME CYCLE}

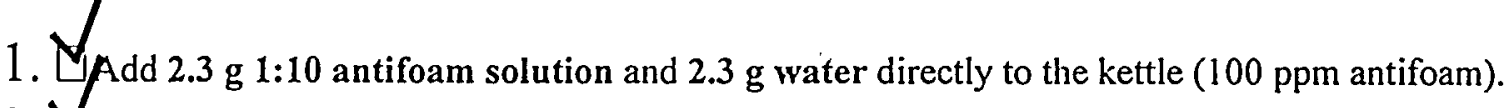

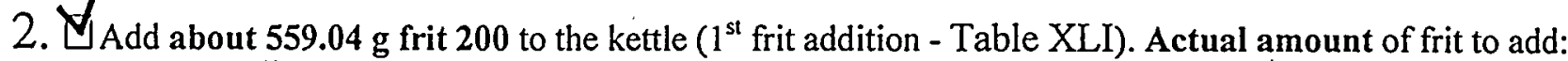
$550.91 \mathrm{~g}^{12}$

3. Add about $11.39 \mathrm{~g}$ of 90 -wt $\%$ formic acid to the kettle ( $1^{\text {st }}$ formic addition - Table XLI). Actual amount of formic to add: $11.22 \mathrm{~g}^{12}$

4. Add about $\mathbf{1 0 2 6 . 8 3} \mathrm{g}$ of water to the kettle ( $1^{\text {st }}$ water addition - Table XLI). Actual amount of 5.

5. Bring kettle contents to boiling. Record the run data every 20 minutes on the data sheet.

6. Remove about $1027 \mathrm{~g}$ of water (about 5 hours). Actual amount of water to remove: $648.8 \mathrm{~g}^{13}$

7. When dewatering is complete, turn off the heat to cool the kettle to sub-boiling.

8. Add about $559.04 \mathrm{~g}$ frit 200 to the kettle ( $2^{\text {nd }}$ frit addition - Table XLI). Actual amount of frit to add: $550.91 \mathrm{~g}^{12}$

9. $\square_{\text {Add about }} 11.39 \mathrm{~g}$ of 90 -wt $\%$ formic acid to the kettle ( $2^{\text {nd }}$ formic addition - Table XLI).Actual pmount of formic to add: $11.22 \mathrm{~g}^{12}$

10. Add about $1026.83 \mathrm{~g}$ of water to the kettle $\left(2^{\text {nd }}\right.$ water addition - Table XLI). Actual amount of Nater to add: $1011.89 \mathrm{~g}^{12}$

11. Bring kettle contents to boiling. Record the run data every 20 minutes on the data sheet.

12. Remove about $1027 \mathrm{~g}$ of water (about 5 hours). Actual amount of water to remove: $648.8 \mathrm{~g}^{13}$

13. When dewatering is complete, turn off the heat to cool the kettle to sub-boiling. Turn on cooling water

14. Pull a 125-ml sample from the kettle, record the weight on the run sheet. Label as LB SME $1 V^{*}$

Final and send to lab for analyses.

15. Stop GC and record the GC time and clock time in the logbook. Stop recording run data on the data sheet

16. Install the calibration gas cylinder to the GC and run the post-cal check. If the check indicates OK, print a copy and write "post-cal check and run number" on the printout, then place the GC in standby.

If the check is not within $10 \%$ of the cal gas composition, notify the engineer.

17. Pump kettle contents into a tared bottle. Record the weight on the run sheet.

18. Whomplete $\mathrm{pH}$ meter post calibration check. Record measured $\mathrm{pH}$ in $\mathrm{pH} 7$ buffer 7.3 .

19. Install the outlet flow meter to the purge gas. Perform leak check.

20. When the kettle is cool $\left(<50^{\circ} \mathrm{C}\right)$, record the outlet purge flow in the log book. (All channels).

21. $\$$ Turn off all instruments.

${ }^{12}$ Actual amounts calculated after account for SRAT samples pulled and other losses.

${ }^{13}$ Amounts recalculated to reach $45 \mathrm{wt} \%$ solids in SME product after account for samples pulled and other losses. 
Westinghouse Savannah River Company Savannah River Technology Center

Run \# 4V
APPENDIX A-4: Runs 1V/4V

WSRC-TR-99-00111, Rev. 0

Page 80 of 111

Date: $11 / 19 / 99$

\section{PREPARATION FOR SRAT CYCLE}

Note: 70 not insulate kettle until acid addition is complete

1. Add $2000 \mathrm{~g}$ of Sludge $\mathbf{B}^{\prime}$ to kettle using 2-liter transfer bottle or beaker.

2. $y$ Add $389.6 \mathrm{~g}$ of SRAT Heel $\mathrm{A}^{\prime}$ to kettle using 2-liter transfer bottle or beaker.

3. T Turn on kettle agitator. Setpoint $=200 \mathrm{rpm}$. Mark Sludge Level in Kettle as De-water Level for

4. later de-watering and concentration.

5. Transfer $287.4 \mathrm{ml}$ of distilled water to the kettle (use to rinse all containers used for adding sludge,

noble metals, mercury, etc.).

6. Calibrate $\mathrm{pH}$ probe with $\mathrm{pH} 4$ and 10 buffer. Record measured $\mathrm{pH}$ of $\mathrm{pH} 7$ buffer $\_.930$.

7. Install $\mathrm{pH}$ probe in kettle. Record initial $\mathrm{pH}$ of sludge 11.531 .

8. Turn on the air purge to kettle at $\mathbf{1 0 0 . 0} \mathrm{sccm}$. Connect the outlet flowmeter to perform the leak check. The outlet flow should be $\mathbf{9 0 - 1 1 0 ~ s c c m}$. If it is not, tighten all connections until the system is leak

9. Disconnect outlet flowmeter.

10. $\mathrm{Set}$ the air flow to kettle at $466.5 \mathrm{sccm}$. Set the He flow to $2.34 \mathrm{sccm}$.

11. Turn on cooling water to SRAT condenser. Setpoint $=40^{\circ} \mathrm{C}$.

12. Turn on cooling water to Chilled (FAVC) condenser. Setpoint $=\mathbf{1 0}^{\circ} \mathrm{C}$.

13. Make sure the GC computer has enough memory space for the run (at least 40 Mbyte).

14. 4 Set the GC computer time equal to the clock time. Record the time in the log book.

15. Install the calibration gas cylinder to the $\mathrm{GC}$ and let the $\mathrm{GC}$ run five times. If at the end of five runs the $\mathrm{GC}$ reading is within $10 \%$ of the gas composition in the cylinder, print the calibration check results and write down "pre-cal check and run number" on the printout. Otherwise, select "Calibration" "Level 1" "OK" to calibrate the GC five times. At the end of five runs the GC reading should be within $10 \%$ of the gas composition in the cylinder. If it is not, contact the engineer. Print

16. $\checkmark$ Start the GC for this run beginning with baseline reading for a few minutes. Write down the GC time, filename etc. in the logbook. Record the baseline data on the data sheet. 
Westinghouse Savannah River Company Savannah River Technology Center

Run \# 4V
APPENDIX A-4: Runs IV/4V

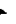

1. $\otimes_{\text {Adart }}$ on its power switch, press the [SEL] key for 3 seconds until display shows "roFF". Press the $[\wedge]$ key until display shows "rrUn" then press and hold the [SEL] key until the normal display appears. The Therm-O-Watch will ramp up to $93^{\circ} \mathrm{C}$ and hold at $93^{\circ} \mathrm{C}$. Record the run data pvery 20 minutes on the data sheet.

3. Hook the heating mantle to the Cole-Parmer (gray box) temperature controller, and switch on

4. If Cole-Parmer unit. Bring the kettle contents to boiling. water pump to bring the temperature down rapidly. Add antifoam solution as shown in Step 1. Then switch off the cooling coil water pump and slowly heat up the kettle again to the point of boiling.

5. Dewater until remove $287.4 \mathrm{~g}$ of water (kettle volume should be close to De-water Level marked in Step 3 of PREPARATION FOR SRAT CYCLE). Should take about 1 hour and

6. When dewatering is complete, turn off the heat to kettle, turn on water to cooling coil, and cool the kettle to sub-boiling $\left(90^{\circ} \mathrm{C}\right)$.

7. Add 333.3 g of Sludge B' to the kettle using 2-liter transfer bottle or beaker.

8. Add second batch of trim chemicals (from Table XL) directly to the kettle.

9. Transfer $50 \mathrm{ml}$ of distilled water to the kettle (use to rinse all containers used for adding 10. Pludge, noble metals, mercury, etc.).

10. Allow slurry to cool to $50^{\circ} \mathrm{C}$, monitoring torque every 20 minutes.

11. Dull $10 \mathrm{ml}$ sample for nitrate, nitrite, and formate analysis. Label LB SRAT $4 \mathrm{~V}^{*}-0 \mathrm{~N}$.

12. Start heating up the kettle with the Therm-O-Watch (yellow box) temperature controller. Press the [SEL] key for 3 seconds until display shows "roFF". If display shows "rrUn", press the $[\wedge]$ or [V] key until display shows "roFF". Press the [^] or [V] key until display shows "rrUn" then press and hold the [SEL] key until the normal display appears. The Therm-O-

Watch will ramp up to $93^{\circ} \mathrm{C}$ and hold at $93^{\circ} \mathrm{C}$. Record the run data every 20 minutes on the 13. pata sheet.

13. Once at $93^{\circ} \mathrm{C}$, add $52.37 \mathrm{ml}$ of $50-\mathrm{wt} \%$ nitric acid at $0.669 \mathrm{ml} / \mathrm{min}$ (reference Table XLII) to the kettle. Should take about 1 hour and 20 minutes.

14. Add $117.14 \mathrm{ml}$ of $90-\mathrm{wt} \%$ formic acid at $0.687 \mathrm{ml} / \mathrm{min}$ (reference Table XLII) to the kettle. Should take about 2 hours and 55 minutes.

15. Add $2.3 \mathrm{~g}$ 1:10 antifoam solution and $2.3 \mathrm{~g}$ water directly to the kettle (100 ppm antifoam). 16. Hook the heating mantle to the Cole-Parmer (gray box) temperature controller and switch on the Cole-Parmer unit. Bring the kettle contents to boiling.

17. Dewater until collect $846 \mathrm{~g}$ of $\mathrm{H} 2 \mathrm{O}$ in the SMECT leaving approximately $1.7 \mathrm{~L}$ in the kettle. Should take about 4 hours and 15 minutes. (Collected $847.4 \mathrm{~g}$ )

18. Pull $10 \mathrm{mI}$ sample for nitrate, nitrite, and formate analysis. Label LB SRAT $4 V^{*}-1 \mathrm{~N}$. 
Westinghouse Savannah River Company

Savannah River Technology Center
APPENDIX A-4: Runs 1V/4V

Run \# $4 \mathrm{~V}$
Date: $\quad 1 / 20 / 99$

WSRC-TR-99-00111, Rev. 0

Page 82 of 111

\section{SRAT CYCLE (continued)}

19. Add $2.3 \mathrm{~g}$ 1:10 antifoam solution and $2.3 \mathrm{~g}$ water directly to the kettle (100 ppm antifoam).

20. Reflux the slurry for $\mathbf{1 4 . 6}$ hours or more (including the dewater time in step 18) at 3.4 g/min boil-up taking $10 \mathrm{ml}$ sample for nitrate, nitrite, and formate analysis every 2 hours and one at the end. Continue refluxing until there is evidence of nitrite destruction (hydrogen release) and the hydrogen has reached its peak. Then turn off the heat to cool the kettle to sub-boiling. Weigh samples and record in lab book. Add $1 \mathrm{ml}$ of $1 \mathrm{~N} \mathrm{NaOH}$ solution to each sample, reweigh, and record in lab book. Label as LB SRAT 4V*-2N, 4N, $6 \mathrm{~N}, 8 \mathrm{~N}, 10 \mathrm{~N}$, etc.

21. $\forall$ Pull a $125 \mathrm{ml}$ sample from the kettle, record the weight on the run sheet. Label as LB SRAT $4 \mathrm{~V}^{*}$ and send to lab for analyses.

22. Pull a $\underline{125} \mathrm{ml}$ sample from the kettle, record the weight on the run sheet. Label as LB SRAT AV* Rheology and send to lab for Rheology.

23. $\checkmark$ Remove Sampler and insert rubber stopper in port. 
Westinghouse Savannah River Company Savannah River Technology Center

Run \# 4V
APPENDIX A-4: Runs 1V/4V

WSRC-TR-99-00111, Rev. 0

Page 83 of 111

Date: 1/21/99

\section{SME CYCLE}

1.

Add $2.3 \mathrm{~g} 1: 10$ antifoam solution and $2.3 \mathrm{~g}$ water directly to the kettle (100 ppm antifoam).

2. $\nabla$ Add about $540.04 \mathrm{~g}$ of frit 200 to the kettle ( $1^{\text {st }}$ frit addition - Table XLI). Actual amount of frit to add: $541.15 \mathrm{~g}^{14}$ (Added $541.2 \mathrm{~g}$ )

3. Add about $11.00 \mathrm{~g}$ of $90-\mathrm{wt} \%$ formic acid to the kettle ( $1^{\text {st }}$ formic addition - Table XLI). Actual Amount of formic to add: $11.02 \mathrm{~g}^{14}$

4. Add about $991.93 \mathrm{~g}$ of water to the kettle $\left(1^{\text {st }}\right.$ water addition - Table XLI). Actual amount of water to remove: $993.98 \mathrm{~g}^{14}$ (Added $\left.994.0 \mathrm{~g}\right)$

5. Bring kettle contents to boiling. Record the run data every 20 minutes on the data sheet.

6. Remove about $992 \mathrm{~g}$ of water (about 5 hours). Actual amount of water to remove: $672.5 \quad \mathrm{~g}^{15}$

7. When dewatering is complete (about 3.4 hours), turn off the heat to cool the kettle to sub-boiling.

8. $\nabla_{\text {Add about }} \mathbf{5 4 0 . 0 4} \mathrm{g}$ of frit 200 to the kettle ( $1^{\text {st }}$ frit addition - Table XLI). Actual amount of frit to add: $541.15 \mathrm{~g}^{14}$ (Added $\left.5412 \mathrm{~g}\right)$

9. Add about $11.00 \mathrm{~g}$ of $90-\mathrm{wt} \%$ formic acid to the kettle ( $1^{\text {st }}$ formic addition - Table XLI). Actual pamount of formic to add: $11.02 \quad \mathrm{~g}^{14}$

10. Add about $991.93 \mathrm{~g}$ of water to the kettle $\left(1^{\text {st }}\right.$ water addition - Table XLI). Actual amount of water fo remove: $993.98 \quad \mathrm{~g}^{14}$ (Added $\left.994.0 \mathrm{~g}\right)$

11. $\triangle$ Bring kettle contents to boiling. Record the run data every 20 minutes on the data sheet.

12. $\nabla_{\text {Remove about } 992 \mathrm{~g} \text { of water (about } 5 \text { hours). Actual amount of water to remove: } 672.5} \mathrm{~g}^{15}$ (Removed $674.8 \mathrm{~g}$ )

13. When dewatering is complete, turn off the heat to cool the kettle to sub-boiling. . Turn on cooling water to cooling coil dip-leg.

14. Pull a $125-\mathrm{ml}$ sample from the kettle, record the weight on the run sheet. Label as LB SME $4 V^{*}$ and send to lab for analyses.

15. Stop GC and record the GC time and clock time in the log book. Stop recording run data on the data sheet.

16. Install the calibration gas cylinder to the GC and run the post-cal check. If the check indicates OK, print a copy and write "post-cal check and run number" on the printout, then place the GC in standby. If the check is not within $10 \%$ of the cal gas composition, notify the engineer.

17. Pump kettle contents into a tared bottle. Record the weight on the run sheet.

18. Complete $\mathrm{pH}$ meter post calibration check. Record measured $\mathrm{pH}$ in $\mathrm{pH} 7$ buffer 7.25

19. Install the outlet flow meter to the purge gas.

20. When the kettle is cool $\left(<50^{\circ} \mathrm{C}\right)$, record the outlet purge flow in the log book. (All channels). Perform

21. Wurn off all instruments.

${ }^{14}$ Actual amounts calculated after account for SRAT samples pulled and other losses.

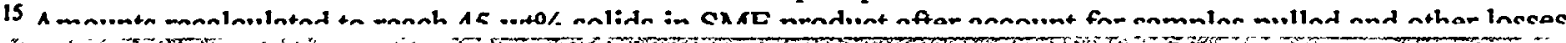


APPENDIX A-5: LARGE BATCH RUNS 5V

SRT-PTD-99-0031, Rev. 0

\author{
CC: E. W. Holtzscheiter, 773-A \\ J. E. Occhipinti, 704-27S \\ S. L. Marra, 704-TS \\ R. E. Edwards, 704-25S \\ R. E. Eibling, 704-1T \\ P. R. Monson, 704-1T \\ D. C. Koopman, 704-T \\ D. P. Lambert, 704-1T \\ M. F. Williams, 704-1T \\ J. W. Duvall, 704-1T \\ M. L-Moss, 772-T \\ S. O. King, 677-T \\ V. J. Williams, 677-T \\ T. O. Burckhalter, 677-T
}

June 16, 1999

TO: $\quad$ L. F. Landon, 704-1T

FROM: W. E. Daniel, 704-1T

\title{
Run Plan for Extra Large Batch Variability Run for Developing Strategies for Increased CPC Batch Sizes (U)
}

This run plan documents an extra variability run regarding the Task Technical Plan for Developing Strategy for Increased CPC Batch Size (WSRC-RP-98-00354) as requested in DWPF Technical Task Request HLW/DWPT/TTR-980013. The experimental work will be controlled using the Laboratory Scale Chemical Process Cell Simulations (Manual L27, Procedure 2.02) and this run plan. This run plan includes many of the experimental details, the instructions for final sludge preparation, the scaling necessary for determining the operating conditions such as feed rates, purge rates, and the steps in completing the SRAT and SME cycles. This document also summarizes the decisions made to complete these experiments.

1) The sludge used for the SRAT Heel preparation is a Tank 42-sludge simulant created from the Optima Tank 51 simulant with the following modifications.

a) A recipe is shown in Table XLV that targets a 20 weight percent solids sludge after the trim chemicals (noble metals and mercury) are added. This sludge will be referred to as Sludge $A^{\prime}$ and its pre-trim measured as well as post-trim predicted elemental weight percent analyses are shown in Table XLVI. Estimated elementals of the SRAT Heel used in this experiment are shown in Table XLVII.

b) Tank 42 levels of noble metals and mercury will be added to the sludge batches as shown in Table XLVIII and Table XLIX. These levels will require approximately 14 hours of refluxing in the SRAT to steam strip mercury and meet the DWPF constraint of $0.45 \mathrm{wt} \%$ mercury. 
Westinghouse Savannah River Company Savannah River Technology Center

Table XLV. Preparation Of Tank 42 Sludge 22 weight \% (Trim Chemicals Missing)

\begin{tabular}{|c|c|c|}
\hline Component & Amount, $\mathrm{g}$ & Comments \\
\hline Tank 51 sludge simulant & 14613.20 & 18.52 wt\% solids initially \\
\hline Tank 51 supernate & 373.20 & Added Supernate to lower wt\% solids \\
\hline $\mathrm{Al}_{2} \mathrm{O}_{3}$ & 194.98 & \\
\hline $\mathrm{Ni}\left(\mathrm{NO}_{3}\right)_{2}{ }^{*} 6 \mathrm{H}_{2} \mathrm{O}$ & 37.65 &. \\
\hline $\mathrm{SiO}_{2}$ & 25.73 & \\
\hline $\mathrm{MnO}_{2}{ }^{*} \mathrm{x} \mathrm{H}_{2} \mathrm{O}$ & 133.49 & Total Mass @ 71.4 wt\% solids \\
\hline $\mathrm{Water}^{\mathrm{Al}} \mathrm{O}_{3}$ & 200.00 & \\
\hline $\mathrm{Na}_{2} \mathrm{C}_{2} \mathrm{O}_{4}$ & 1.50 & \\
\hline $\mathrm{NaF}$ & 0.00 & \\
\hline $\mathrm{NaOH}$ & 0.88 & \\
\hline $\mathrm{NaCl}$ & 8.69 & \\
\hline & 0.34 & \\
\hline
\end{tabular}

Table XLVI. Elemental Analyses of Large Batch $20 \mathrm{wt} \%$ Sludge $\mathrm{A}^{\prime}$

\begin{tabular}{|c|c|c|c|c|c|}
\hline $\begin{array}{c}\text { Insoluble } \\
\text { Species }\end{array}$ & $\begin{array}{c}\text { Measured } \\
\text { Wt\% Solids } \\
\text { Pre-Trim }\end{array}$ & $\begin{array}{c}\text { Predicted Wt\% } \\
\text { Solids Post- } \\
\text { Trim }\end{array}$ & $\begin{array}{c}\text { Soluble } \\
\text { Species }\end{array}$ & $\begin{array}{c}\text { Measured } \\
\text { Wt\% Solids } \\
\text { Pre-Trim }\end{array}$ & $\begin{array}{c}\text { Predicted } \\
\text { Wt\% } \\
\text { Solids Post- } \\
\text { Trim }\end{array}$ \\
\hline $\mathrm{Al}$ & $5.72 \%$ & $7.58 \%$ & $\mathrm{Al}$ & & $0.02 \%$ \\
\hline${ }^{*} \mathrm{Ag}$ & & $0.04 \%$ & $\mathrm{C} 2 \mathrm{O} 4$ & $0.28 \%$ & $0.27 \%$ \\
\hline $\mathrm{Ca}$ & $2.04 \%$ & $1.94 \%$ & $\mathrm{Cl}$ & $0.04 \%$ & $0.04 \%$ \\
\hline${ }^{*} \mathrm{Cd}$ & & $0.11 \%$ & $\mathrm{CO} 3$ & & $1.81 \%$ \\
\hline $\mathrm{Cl}$ & & $0.07 \%$ & $\mathrm{Cr}$ & & $0.00 \%$ \\
\hline $\mathrm{Cr}$ & & $0.16 \%$ & $\mathrm{~F}$ & $0.01 \%$ & $0.02 \%$ \\
\hline $\mathrm{Cu}$ & $0.02 \%$ & $0.02 \%$ & $\mathrm{~K}$ & & $0.00 \%$ \\
\hline $\mathrm{F}$ & & $0.01 \%$ & $\mathrm{Li}$ & & $0.00 \%$ \\
\hline $\mathrm{Fe}$ & $23.08 \%$ & $21.80 \%$ & $\mathrm{Na}$ & & $0.25 \%$ \\
\hline${ }^{*} \mathrm{Hg}$ & & $1.30 \%$ & $\mathrm{NO} 2$ & $4.38 \%$ & $3.73 \%$ \\
\hline $\mathrm{K}$ & $0.16 \%$ & $0.05 \%$ & $\mathrm{NO} 3$ & $1.80 \%$ & $1.44 \%$ \\
\hline $\mathrm{Li}$ & $0.00 \%$ & $0.00 \%$ & $\mathrm{OH}$ & & $0.12 \%$ \\
\hline $\mathrm{Mg}$ & $1.13 \%$ & $1.11 \%$ & $\mathrm{PO} 4$ & $0.06 \%$ & $0.05 \%$ \\
\hline $\mathrm{Mn}$ & $4.48 \%$ & $3.64 \%$ & $\mathrm{SO} 4$ & $0.26 \%$ & $0.21 \%$ \\
\hline $\mathrm{Na}$ & $7.88 \%$ & $5.74 \%$ & & & \\
\hline $\mathrm{Ni}$ & $0.35 \%$ & $0.34 \%$ & & & \\
\hline $\mathrm{P}$ & & $0.00 \%$ & & & \\
\hline${ }^{*} \mathrm{Pd}$ & & $0.00 \%$ & & & \\
\hline $\mathrm{Pu}$ & & $0.00 \%$ & & & \\
\hline${ }^{*} \mathrm{Rh}$ & & $0.01 \%$ & & & \\
\hline${ }^{*} \mathrm{Ru}$ & & $0.02 \%$ & & & \\
\hline $\mathrm{Se}$ & & $0.00 \%$ & & & \\
\hline $\mathrm{Si}$ & $1.64 \%$ & $1.80 \%$ & & & \\
\hline $\mathrm{Te}$ & & $0.00 \%$ & & & \\
\hline $\mathrm{Ti}$ & $0.05 \%$ & $0.05 \%$ & & & \\
\hline $\mathrm{U}$ & & $0.00 \%$ & & & \\
\hline $\mathrm{Zn}$ & $0.01 \%$ & .0 .00 & & & \\
\hline & & & & \\
\hline & & & & \\
\hline
\end{tabular}


Westinghouse Savannah River Company

Savannah River Technology Center

APPENDIX A-5: Run 5V

WSRC-TR-99-00111, Rev. 0

Page 86 of 111

Table XLVII. Estimated Elementals for Second SRAT Heel prepared from Sludge A'

\begin{tabular}{|c|c|c|c|}
\hline $\begin{array}{l}\text { Insoluble } \\
\text { Species }\end{array}$ & $\begin{array}{c}\text { Estimated } \\
\text { Wt } \% \text { Solids }\end{array}$ & $\begin{array}{l}\text { Soluble } \\
\text { Species }\end{array}$ & $\begin{array}{c}\text { Estimated } \\
\text { Wt } \% \text { Solids }\end{array}$ \\
\hline $\mathrm{Al}$ & $5.55 \%$ & $\mathrm{Al}$ & $0.02 \%$ \\
\hline $\mathrm{Ag}$ & $0.037 \%$ & $\mathrm{C} 2 \mathrm{O} 4$ & $0.27 \%$ \\
\hline $\mathrm{Ca}$ & $1.98 \%$ & $\mathrm{Cl}$ & $0.04 \%$ \\
\hline $\mathrm{Cd}$ & $0.11 \%$ & $\mathrm{CO} 3$ & $1.70 \%$ \\
\hline $\mathrm{Cl}$ & $0.06 \%$ & $\mathrm{Cr}$ & $0.00 \%$ \\
\hline $\mathrm{Cr}$ & $0.16 \%$ & $\mathrm{~F}$ & $0.01 \%$ \\
\hline $\mathrm{Cu}$ & $0.02 \%$ & $\mathrm{~K}$ & $0.00 \%$ \\
\hline$F$ & $0.01 \%$ & $\mathrm{Li}$ & $0.00 \%$ \\
\hline $\mathrm{Fe}$ & $22.4 \%$ & $\mathrm{Na}$ & $0.24 \%$ \\
\hline $\mathrm{Hg}$ & $1.30 \%$ & NO2 & $4.25 \%$ \\
\hline $\mathrm{K}$ & $0.16 \%$ & NO3 & $1.84 \%$ \\
\hline $\mathrm{Li}$ & $0.00 \%$ & $\mathrm{OH}$ & $0.12 \%$ \\
\hline $\mathrm{Mg}$ & $1.10 \%$ & $\mathrm{PO} 4$ & $0.06 \%$ \\
\hline $\mathrm{Mn}$ & $4.35 \%$ & SO4 & $0.25 \%$ \\
\hline $\mathrm{Na}$ & $7.65 \%$ & & \\
\hline $\mathrm{Ni}$ & $0.34 \%$ & & \\
\hline $\mathrm{P}$ & $0.00 \%$ & & \\
\hline $\mathrm{Pd}$ & $0.0022 \%$ & & \\
\hline $\mathrm{Pu}$ & $0.00 \%$ & & \\
\hline $\mathrm{Rh}$ & $0.0053 \%$ & & \\
\hline $\mathrm{Ru}$ & $0.022 \%$ & & \\
\hline $\mathrm{Se}$ & $0.00 \%$ & & \\
\hline $\mathrm{Si}$ & $1.59 \%$ & & \\
\hline $\mathrm{Te}$ & $0.00 \%$ & & \\
\hline $\mathrm{Ti}$ & $0.05 \%$ & & \\
\hline $\mathrm{U}$ & $0.00 \%$ & & \\
\hline $\mathrm{Zn}$ & $0.01 \%$ & & \\
\hline
\end{tabular}


Westinghouse Savannah River Company

Savannah River Technology Center
APPENDIX A-5: Run 5V

WSRC-TR-99-00111, Rev. 0

Page 87 of 111

Table XLVIII. Trim Chemical Addition for First Sludge Addition for Run LB 5V

\begin{tabular}{|c|c|c|c|c|c|c|}
\hline & & $\begin{array}{c}\text { Target } \\
\text { Addition, } \mathrm{g}\end{array}$ & \begin{tabular}{|c|} 
Actual Addition, \\
$\mathrm{g}$
\end{tabular} & $\begin{array}{l}\text { Wt\% Solids } \\
\text { w/o Trim }\end{array}$ & $\begin{array}{l}\text { Target Solids } \\
\text { w/Trim, } \mathrm{g}^{9}\end{array}$ & $\begin{array}{l}\text { Actual Solids } \\
\text { added, } g^{9}\end{array}$ \\
\hline Sludge $A^{\prime}$ & & 2000.0 & & $19.3 \%$ & 393.1 & \\
\hline Trim Chemicals & $\begin{array}{c}\text { Wt\% Species in } \\
\text { Solution } \\
\end{array}$ & \begin{tabular}{|c|} 
Target \\
Addition, grams \\
\end{tabular} & $\begin{array}{c}\text { Actual Addition, } \\
\text { grams }\end{array}$ & $\begin{array}{l}\text { Elemental } \\
\text { Solids Factor }\end{array}$ & $\begin{array}{l}\text { Target Elemental } \\
\text { Solids, } \mathrm{g}\end{array}$ & $\begin{array}{l}\text { Actual Elemental } \\
\text { Solids, } g\end{array}$ \\
\hline AgNO3 & $100.00 \%$ & \begin{tabular}{|l|}
0.236 \\
\end{tabular} & & 0.6349 & 0.150 & \\
\hline $\mathrm{HgO}$ & $100.00 \%$ & 5.626 & & 0.9261 & 5.210 & \\
\hline $\mathrm{Pd}(\mathrm{NO} 3) 2 * \mathrm{H} 2 \mathrm{O}$ & $15.27 \%^{16}$ & 0.058 & & 0.1527 & 0.00883 & \\
\hline $\mathrm{Rh}(\mathrm{NO3}) 3 * 2 \mathrm{H} 2 \mathrm{O}$ & $4.93 \%^{8}$ & 0.431 & & 0.0493 & 0.02125 & \\
\hline $\mathrm{RuCl} 3$ & $41.74 \%^{8}$ & 0.211 & & 0.4174 & 0.0881 & \\
\hline $\mathrm{Cd}(\mathrm{NO} 3) 2 * 4 \mathrm{H} 2 \mathrm{O}$ & $100.00 \%$ & 1.208 & & 0.3644 & 0.440 & \\
\hline
\end{tabular}

\begin{tabular}{|c|c|c|c|}
\hline Element & & $\begin{array}{c}\text { Target Wt\% } \\
\text { Solids }\end{array}$ & $\begin{array}{c}\text { Actual Wt\% } \\
\text { Solids }\end{array}$ \\
\hline $\mathrm{Ag}$ & & $0.037 \%$ & \\
\hline $\mathrm{Hg}$ & & $1.30 \%$ & \\
\hline $\mathrm{Pd}$ & & $0.0022 \%$ & \\
\hline $\mathrm{Rh}$ & & $0.0053 \%$ & \\
\hline $\mathrm{Ru}$ & & $0.022 \%$ & \\
\hline $\mathrm{Cd}$ & & $0.11 \%$ & \\
\hline
\end{tabular}

. Table XLIX. Trim Chemical Addition for Second Sludge Addition for Run LB 5V

\begin{tabular}{|c|c|c|c|c|c|c|}
\hline & & $\begin{array}{c}\text { Target } \\
\text { Addition, } \mathrm{g}\end{array}$ & $\begin{array}{c}\text { Actual Addition, } \\
\mathrm{g}\end{array}$ & $\begin{array}{l}\text { Wt\% Solids } \\
\text { w/o Trim }\end{array}$ & $\begin{array}{l}\text { Target Solids } \\
\text { w/Trim, } \mathrm{g}^{9}\end{array}$ & $\begin{array}{l}\text { Actual Solids } \\
\text { added, } \mathrm{g}^{9}\end{array}$ \\
\hline Sludge $A^{\prime}$ & & 333.3 & & $19.3 \%$ & 65.5 & \\
\hline Trim Chemicals & $\begin{array}{l}\text { Wt\% Species in } \\
\text { Solution }\end{array}$ & $\begin{array}{c}\text { Target } \\
\text { Addition, grams }\end{array}$ & $\begin{array}{c}\text { Actual Addition, } \\
\text { grams }\end{array}$ & $\begin{array}{l}\text { Elemental } \\
\text { Solids Factor }\end{array}$ & $\begin{array}{l}\text { Target Elemental } \\
\text { Solids, } \mathrm{g}\end{array}$ & $\begin{array}{l}\text { Actual Elemental } \\
\text { Solids, } \mathrm{g}\end{array}$ \\
\hline AgNO3 & $100.00 \%$ & 0.039 & & 0.6349 & 0.025 & \\
\hline HgO & $100.00 \%$ & 0.937 & & 0.9261 & 0.868 & \\
\hline $\mathrm{Pd}(\mathrm{NO3}) 2^{*} \mathrm{H} 2 \mathrm{O}$ & $15.27 \%^{8}$ & 0.010 & & 0.1527 & 0.00147 & \\
\hline $\mathrm{Rh}(\mathrm{NO3}) 3 * 2 \mathrm{H} 2 \mathrm{O}$ & $4.93 \%^{8}$ & 0.072 & & 0.0493 & 0.00354 & \\
\hline $\mathrm{RuCl} 3$ & $41.74 \%^{8}$ & 0.035 & & 0.4174 & 0.0147 & \\
\hline $\mathrm{Cd}(\mathrm{NO}) 2 * 4 \mathrm{H} 2 \mathrm{O}$ & $100.00 \%$ & 0.203 & & 0.3644 & 0.074 & \\
\hline
\end{tabular}

\begin{tabular}{|c|c|c|c|}
\hline Element & & $\begin{array}{c}\text { Target Wt\% } \\
\text { Solids }\end{array}$ & $\begin{array}{c}\text { Actual Wt\% } \\
\text { Solids }\end{array}$ \\
\hline $\mathrm{Ag}$ & & $0.037 \%$ & \\
\hline $\mathrm{Hg}$ & & $1.30 \%$ & \\
\hline $\mathrm{Pd}$ & & $0.0022 \%$ & \\
\hline $\mathrm{Rh}$ & & $0.0053 \%$ & \\
\hline $\mathrm{Ru}$ & & $0.022 \%$ & \\
\hline $\mathrm{Cd}$ & & $0.11 \%$ & \\
\hline
\end{tabular}

${ }^{16}$ These values represent the weight percent of elemental $\mathrm{Pd}, \mathrm{Rh}$, or $\mathrm{Ru}$ in their respective solutions.

${ }^{17}$ These values include the weight and/or solids of the added trim chemicals. 
2) The batching of the materials is designed to produce a glass containing $26 \mathrm{wt} \%$ calcined sludge solids and $74 \mathrm{wt} \%$ frit 200 . A batching summary is shown in Table XXX.

3) Calculated acid addition rates, boilup rates, purge rates, antifoam addition, etc. were based on scaling from DWPF settings as shown in Table LI.

4) Run $5 \mathrm{~V}$ simulates a processing scenario where the sludge solids are high (about $20 \mathrm{wt} \%$ ) and a $150 \%$ acid stoichiometry is used to ensure nitrite destruction. The redox calculation spreadsheets for the Variability Run LB 5V are shown in Table LII.

5) The reflux time in the SRAT cycle will be extended until there is evidence of nitrite destruction.

6) A review, as required by the Conduct of Research and Development was completed and is contained in Appendix B.

7) The experiments should be completed the week of June 14, 1999.

Table L. Batching Summary for Variability Run LB 5V

\begin{tabular}{|l|r|}
\hline \multicolumn{1}{|c|}{ Batching Summary } & Run LB 5V \\
\hline Sludge \& Heel Mass & $2733.3 \mathrm{~g}$ \\
\hline Nitric Acid Volume, $\mathrm{ml}$ & $51.18 \mathrm{ml}$ \\
\hline Formic Acid Volume, $\mathrm{ml}$ & $117.87 \mathrm{ml}$ \\
\hline SRAT Product Sample, ml & 125 \\
\hline Frit 200 Addition \#1, g & $534.23 \mathrm{~g}$ \\
\hline SME Water Addition \#1, g & $981.25 \mathrm{~g}$ \\
\hline SME 90 wt\% Formic Acid Addition \#1, g & $10.88 \mathrm{~g}$ \\
\hline Frit 200 Addition \#2, g & $534.23 \mathrm{~g}$ \\
\hline SME Water Addition \#2, g & $981.25 \mathrm{~g}$ \\
\hline SME 90 wt\% Formic Acid Addition \#2,g & $10.88 \mathrm{~g}$ \\
\hline SRAT Air Purge ${ }^{\ddagger}$, scc/min & 466.5 \\
\hline SRAT Helium purge, scc/min & 2.34 \\
\hline SME Air Purge ${ }^{\ddagger}$, scc/min & 163.8 \\
\hline SME Helium purge, scc/min & 0.82 \\
\hline
\end{tabular}

:Actual SRAT Gas Purge equivalent to this Air purge plus the Helium Purge. 


\section{Page 89 of 111}

Table LI. Scaling Calculations for Large Batch Variability Runs 5V

\begin{tabular}{|c|c|c|c|}
\hline & DWPF & TNX LB 5V & Time \\
\hline Scale factor & & $11,355(12831)^{\dagger}$ & \\
\hline Sludge Added Volume & $7,000 \mathrm{gal}$ & $2065 \mathrm{ml}$ & \\
\hline Sludge Heel Volume & $1,200 \mathrm{gal}$ & $354 \mathrm{ml}$ & \\
\hline Sludge Added Density & 1.13 & 1.13 & \\
\hline Sludge Heel Density & 1.13 & 1.13 & \\
\hline Sludge Added Mass & $29941 \mathrm{~kg}$ & $2333.3 \mathrm{~g}$ & \\
\hline Sludge Heel Mass & $5133 \mathrm{~kg}$ & $400.0 \mathrm{~g}$ & \\
\hline SRAT Added Water & $1,000 \mathrm{gal}$ & $295.0 \mathrm{ml}$ & $2.3 \mathrm{hrs}$ boil \\
\hline SRAT purge air ${ }^{\ddagger}$ & $188 \mathrm{scfm}$ & $466.5 \mathrm{scc} / \mathrm{min}$ & \\
\hline SRAT He purge & $0.50 \mathrm{vol} \%$ & $2.34 \mathrm{scc} / \mathrm{min}$ & \\
\hline SME purge air ${ }^{\ddagger}$ & $66 \mathrm{scfm}$ & $163.8 \mathrm{scc} / \mathrm{min}$ & \\
\hline SME He purge & $0.50 \mathrm{vol} \%$ & $0.82 \mathrm{scc} / \mathrm{min}$ & \\
\hline Antifoam (100 ppm in Total Sludge) & $7.73 \mathrm{lbs}$ & $0.23 \mathrm{~g}$ & \\
\hline Antifoam Solution ( 20 to 1 solution) & $154.65 \mathrm{lbs}$ & $4.67 \mathrm{~g}$ & \\
\hline nitric acid feedrate & $2 \mathrm{gpm}$ & $0.663 \mathrm{ml} / \mathrm{min}$ & $1.2 \mathrm{hrs}$ feed \\
\hline formic acid feedrate & $2 \mathrm{gpm}$ & $0.687 \mathrm{ml} / \mathrm{min}$ & $3.0 \mathrm{hrs}$ feed \\
\hline boilup rate & $5,000 \mathrm{lb} / \mathrm{hr}$ & $3.33 \mathrm{~g} / \mathrm{min}$ & \\
\hline Formic Molarity & $23.55 \mathrm{M}$ & $22.85 \mathrm{M}$ & \\
\hline Nitric Molarity & $10.35 \mathrm{M}$ & $10.40 \mathrm{M}$ & \\
\hline Formic Volume & $343.1 \mathrm{gal}$ & $117.87 \mathrm{ml}$ & \\
\hline Formic Mass & & $141.97 \mathrm{~g}$ & \\
\hline Nitric Volume & $154.3 \mathrm{gal}$ & $51.18 \mathrm{ml}$ & \\
\hline Nitric Mass & & $67.07 \mathrm{~g}$ & \\
\hline formic feed time & $171.5 \mathrm{~min}$ & $171.5 \mathrm{~min}$ & \\
\hline Nitric feed time & $77.1 \mathrm{~min}$ & $77.1 \mathrm{~min}$ & \\
\hline Total Vol & & $2882.88 \mathrm{ml}$ & \\
\hline Frit Volume, gallons & $3,561 \mathrm{gal}$ & $1187.170 \mathrm{~g}$ & \\
\hline Frit Density & 1.5 & & \\
\hline Frit wt \% solids & $60 \%$ & & \\
\hline Frit Solids & $26,747.4 \mathrm{lbs}$ & $1068.453 \mathrm{~g}$ & \\
\hline Formic Acid & $490.4 \mathrm{lbs}$ & $19.588 \mathrm{~g}$ & \\
\hline Water & $32,201.0 \mathrm{lbs}$ & $1286.298 \mathrm{~g}$ & \\
\hline Transfer Water & $16,982.5 \mathrm{lbs}$ & $678.383 \mathrm{~g}$ & \\
\hline Total Water & $49,183.5 \mathrm{lbs}$ & $1964.681 \mathrm{~g}$ & \\
\hline Total & $76,421.3 \mathrm{lbs}$ & $3052.722 \mathrm{~g}$ & \\
\hline
\end{tabular}

${ }^{t}$ Value in parentheses represents corrected value due to scale factor error.

${ }^{ \pm}$Actual SRAT/SME Gas Purge equivalent to this Air purge plus the Helium Purge. 
Westinghouse Savannah River Company

APPENDIX A-5: Run 5V

WSRC-TR-99-00111, Rev. 0

Page 90 of 111

Table LI. Scaling Calculations for Large Batch Variability Run LB 5V Continued

\begin{tabular}{|c|c|c|c|}
\hline & DWPF & TNX LB 5V & Time \\
\hline frit 200 & $26,747.4 \mathrm{lbs}$ & $1068.453 \mathrm{~g}$ & \\
\hline 90 wt \% formic acid & $544.9 \mathrm{lbs}$ & $21.765 \mathrm{~g}$ & \\
\hline water & $49,129.0 \mathrm{lbs}$ & $1962.505 \mathrm{~g}$ & \\
\hline Total & $76,421.3 \mathrm{lbs}$ & $3052.722 \mathrm{~g}$ & \\
\hline & & & \\
\hline frit 200 Addition 1 & $13,373.7 \mathrm{lbs}$ & $534.226 \mathrm{~g}$ & \\
\hline 90 wt \% formic addition 1 & $272.4 \mathrm{lbs}$ & $10.882 \mathrm{~g}$ & \\
\hline water addition 1 & $24,564.5 \mathrm{lbs}$ & $981.252 \mathrm{~g}$ & $4.9 \mathrm{hrs}$ boil \\
\hline frit 200 Addition 2 & $13,373.7 \mathrm{lbs}$ & $534.226 \mathrm{~g}$ & \\
\hline 90 wt \% formic addition 2 & $272.4 \mathrm{lbs}$ & $10.882 \mathrm{~g}$ & \\
\hline water addition 2 & $24,564.5 \mathrm{lbs}$ & $981.252 \mathrm{~g}$ & $4.9 \mathrm{hrs}$ boil \\
\hline
\end{tabular}


Table LII. Large Batch Variability Run 5V Redox Calculation

\begin{tabular}{|c|c|c|c|c|c|c|}
\hline Stoichiometry ratio: & \multicolumn{2}{|c|}{$150.0 \%(141 \%)^{\dagger}$} & & & Date: & $6 / 16 / 99$ \\
\hline Stream & PHA & Sludge & Frit & & SME & \\
\hline Oxide Contribution (\%) (in SME) & $0.0 \%$ & $26.0 \%$ & $74.0 \%$ & & 18380.1 & kg Calc. Basis \\
\hline Density $(\mathrm{kg} / \mathrm{L})$ & 1.0355 & 1.130 & $n / a$ & & $137.0 \%$ & \\
\hline Total Solids (\%) & $5.38 \%$ & $19.96 \%$ & $n / a$ & & $48.0 \%$ & \\
\hline Calcine Factor (ox/sol) & 1.00 & 0.80 & $n / a$ & & $n / a$ & \\
\hline Hydroxide (M) & $n / a$ & 0.560 & $n / a$ & & $n / a$ & \\
\hline Mercury (ppm) & $n / a$ & 2298.5 & $n / a$ & & $n / a$ & - \\
\hline Total Mn (wt\% solids) & $n / a$ & 4.36 & $n / a \mid$ & & $n / a$ & \\
\hline Soluble Mn (ppm) & $n / a$ & 0.00 & $n / a$ & & $n / a$ & \\
\hline${ }^{*} \mathrm{TIC}(\mathrm{ppm})$ & $n / a$ & 0.00 & $n / a$ & & $n / a$ & \\
\hline Total Acid (M) & 0.240 & $n / a$ & $n / a$ & & $n / a$ & \\
\hline Nitrite (ppm) & 0.0 & 7277.0 & 0.0 & $(\mathrm{~kg} / 100 \mathrm{~kg}$ & frit) & \\
\hline NO2 Destruction & $0.0 \%$ & $100.0 \%$ & $0.0 \%$ & & & \\
\hline Nitrate (ppm) & 1012.1 & 5617.9 & 0.0 & $(\mathrm{~kg} / 100 \mathrm{~kg}$ & frit) & \\
\hline$\%$ nitrite to nitrate conversion & & $35.0 \%$ & & & & \\
\hline Formate (ppm) & 22808.9 & 0.0 & 1.0 & $(\mathrm{~kg} / 100 \mathrm{~kg}$ & frit) & \\
\hline Reaction formate destruction, $\mathrm{kg}$ & & 154.24 & & & & \\
\hline Factor for total formate destruction & & $15.0 \%$ & & & & \\
\hline Total formate destruction, $\mathrm{kg}$ & & 23.14 & & & & \\
\hline Oxide Mass (kg) & 0.0 & 4778.8 & 13601.3 & & 18380.1 & \\
\hline Solids Mass (kg) & 0.00 & 5975.42 & 13601.30 & & 19576.72 & \\
\hline Total Mass (kg) & 0.00 & 29942.84 & $n / a$ & & 40784.83 & \\
\hline Volume (L) & 0.00 & $26,498.09$ & $n / a$ & & 29769.95 & \\
\hline$\%$ Stoichiometry & $n / a$ & $150.0 \%$ & $n / a$ & & $n / a$ & \\
\hline Volume HNO3@50\% (L) & $n / a$ & $3,539.25$ & $n / a$ & & $n / a$ & \\
\hline NO2 Contribution $(\mathrm{kg})$ & 0.000 & 217.893 & 0.000 & & 217.893 & \\
\hline NO2 Remaining (kg) & 0.000 & 0.000 & 0.000 & & 0.000 & \\
\hline NO3 Contribution (kg) & 0.000 & 2515.677 & 0.000 & & 2515.677 & \\
\hline COOH Contribution (kg) & 0.000 & $(154.24)$ & 93.843 & & $(60) .394$ & \\
\hline NO2 (Molar@45\%) & & & & & 0.000 & \\
\hline NO3 (Molar@45\%) & & & & & 1.720 & \\
\hline COOH (Molar@45\%) & & & & & -0.057 & \\
\hline Predicted $\mathrm{Fe}(\mathrm{II}) / \Sigma \mathrm{Fe}$ & & & 0.09 & $\leq$ & BDL@0.03 & $\leq 0.1$ \\
\hline Volume HCOOH@90\% (L) & & & 4426.78 & & 4096.52 & 4481.89 \\
\hline \% Stoichiometry & $\mathrm{n} / \mathrm{a}$ & $150.0 \%$ & $\mathrm{n} / \mathrm{a}$ & & $\mathrm{n} / \mathrm{a}$ & \\
\hline Volume HCOOH@90\% (L) & $\mathrm{n} / \mathrm{a}$ & $1,555.31$ & $\mathrm{n} / \mathrm{a}$ & & $\mathrm{n} / \mathrm{a}$ & \\
\hline NO2 Contribution $(\mathrm{kg})$ & 0.000 & 217.893 & 0.000 & & 217.893 & \\
\hline NO2 Remaining (kg) & 0.000 & 0.000 & 0.000 & & 0.000 & \\
\hline NO3 Contribution (kg) & 0.000 & 244.480 & 0.000 & & 244.480 & \\
\hline $\mathrm{COOH}$ Contribution $(\mathrm{kg})$ & 0.000 & 1625.834 & 93.843 & & 1719.677 & \\
\hline NO2 (Molar@45\%) . & & & & & 0.000 & \\
\hline NO3 (Molar@45\%) & & & & & 0.167 & \\
\hline $\mathrm{COOH}$ (Molar@45\%) & & & & & 1.620 & \\
\hline Predicted $\mathrm{Fe}(\mathrm{II}) / \overline{\mathrm{Fe}}$ & & & 0.09 & $\leq$ & 0.505 & $\leq 0.1$ \\
\hline Volume HNO3@50\%(L) & & & 1430.20 & & & \begin{tabular}{|l|l|} 
& 1388.50 \\
\end{tabular} \\
\hline
\end{tabular}


Westinghouse Savannah River Company

Savannah River Technology Center

APPENDIX A-5: Run 5V

WSRC-TR-99-00111, Rev. 0

Page 92 of 111

Table XVII. Large Batch Variability Run 5V Redox Calculation Continued

\begin{tabular}{|c|c|c|c|c|c|c|}
\hline Stoichiometry ratio: & \multicolumn{2}{|c|}{$150.0 \%(141 \%)^{\dagger}$} & & & Date: & 6/16/99 \\
\hline mol\% Nitric & $\mathrm{n} / \mathrm{a}$ & $16.5 \%$ & $\mathrm{n} / \mathrm{a}$ & & $\mathrm{n} / \mathrm{a}$ & \\
\hline Volume HCOOH@90\% (L) & $\mathrm{n} / \mathrm{a}$ & $1,298.68$ & $n / a$ & & $\mathrm{n} / \mathrm{a}$ & \\
\hline Volume HNO3@50\% (L) & & 583.98 & & & & \\
\hline NO2 Contribution (kg) & 0.000 & 217.893 & 0.000 & & 217.893 & \\
\hline NO2 Remaining $(\mathrm{kg})$ & 0.000 & 0.000 & 0.000 & & 0.000 & \\
\hline NO3 Contribution $(\mathrm{kg})$ & 0.000 & 619.227 & 0.000 & & 619.227 & \\
\hline $\mathrm{COOH}$ Contribution $(\mathrm{kg})$ & 0.000 & 1222.652 & 0.000 & & 1222.652 & \\
\hline NO2 (Molar@45\%) & & & & & 0.000 & \\
\hline NO3 (Molar@45\%) & & & & & 0.423 & \\
\hline COOH (Molar@45\%) & & & & & 1.152 & \\
\hline Predicted $\mathrm{Fe}(\mathrm{II}) / \Sigma \mathrm{Fe}$ & & & 0.09 & $\leq$ & $0.200(0.211)^{\dagger} \leq$ & 0.1 \\
\hline & & & & & & kgb 9 \\
\hline
\end{tabular}

TValue in parentheses represents corrected value due to scale factor error. 
Westinghouse Savannah River Company Savannah River Technology Center

APPENDIX A-5: Run 5V

WSRC-TR-99-00111, Rev. 0

Page 93 of 111

Run \#

$5 \mathrm{~V}$

Date: $6-17-99$

\section{PREREQUISITES}

1. Signed TAR requesting work.

2. Wssued Testing scope and task assignment.

3. Analyze sludge for density, total base (pH 5.5), nitrate, manganese, nitrite, density, solids.

4. Walibrate GC. Calibrate for nitrogen, oxygen, $\mathrm{N}_{2} \mathrm{O}$, hydrogen, and carbon dioxide.

5. Prepare sufficient $90 \%$ formic acid and $50 \%$ nitric acid.

6. Yrepare sufficient antifoam solution or make sure sufficient solution is available.

7. Calculate batching and scaling for experiment based on DWPF parameters.

8. Calculate redox for experiment based on DWPF parameters.

9. $\checkmark$ Setup experimental rig per sketch below.

10. Complete leak checks and water runs.

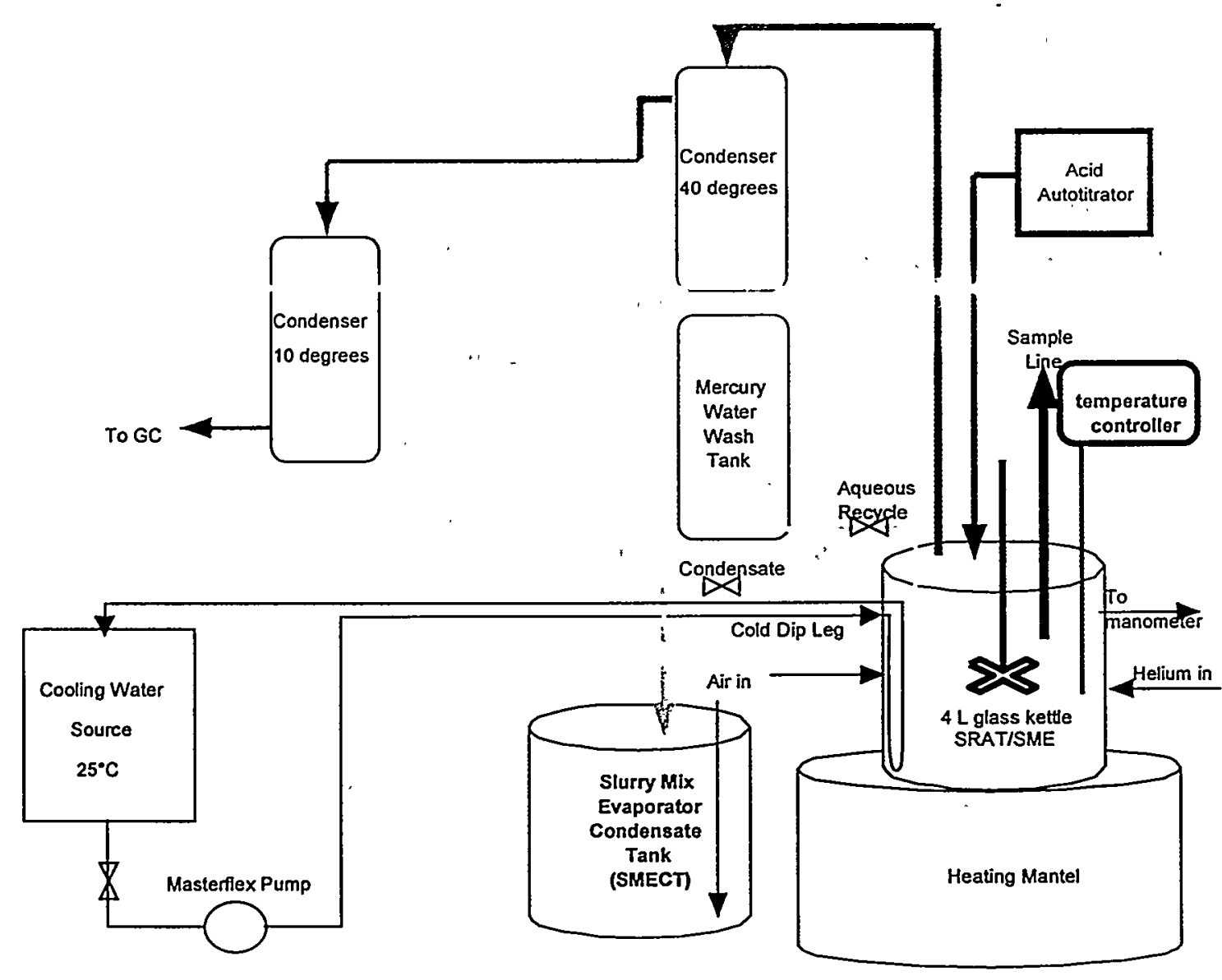


Westinghouse Savannah River Company

Savannah River Technology Center

Run \# 5V
APPENDIX A-5: Run 5V

WSRC-TR-99-00111, Rev. 0

Page 94 of 111

Date: 6-17-99

\section{PREPARATION FOR SRAT CYCLE}

Note: 7 o not insulate kettle until acid addition is complete

1. While agitating kettle, remove all of SRAT Heel A' from previous experiment but $400.0 \mathrm{~g}$. Amount to be removed is _ $1564 \mathrm{~g}=1675 \mathrm{~g}-121.0 \mathrm{~g}$ (wt of LB SRAT Heel 2 sample) (1573 g removed)

2. WAdd $2000 \mathrm{~g}$ of Sludge $\mathrm{A}^{\prime}$ to kettle using 2-liter transfer bottle or beaker. (1999.92 $\mathrm{g}$ added)

3. Set mixer speed to $\mathbf{2 0 0} \mathbf{~ r p m}$. Mark Sludge Level in Kettle as De-water Level for later de-watering and concentration.

4. 4Add first batch of trim chemicals (from Table XLVIII) directly to the kettle.

5. Transfer $295.0 \mathrm{~g}$ of distilled water to the kettle (use to rinse all containers used for adding sludge, poble metals, mercury, etc.).

6. Calibrate $\mathrm{pH}$ probe with pH 4 and 10 buffer. Record measured $\mathrm{pH}$ of $\mathrm{pH} 7$ buffer

7. Install pH probe in kettle. Record initial pH of sludge _done ${ }^{18}$.

8. Turn on the air purge to kettle at $\mathbf{1 0 0 . 0}$ sccm. Connect the outlet flowmeter to perform the leak check. The outlet flow should be $\mathbf{9 0 - 1 1 0 ~} \mathbf{~ s c m}$. If it is not, tighten all connections until the system is leak

9. Disconnect outlet flowmeter.

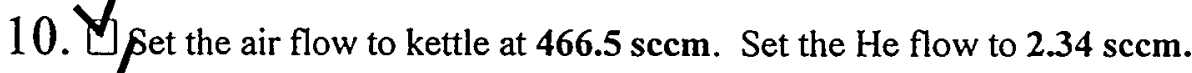

11. $\$$ Turn on cooling water to SRAT condenser. Setpoint $=40^{\circ} \mathrm{C}$.

12. 7 Turn on cooling water to Chilled (FAVC) condenser. Setpoint $=10^{\circ} \mathrm{C}$.

ij. Make sure the $\mathrm{GC}$ computer has enough memory space tor the run (at least 40 Mbyte).

14. Wet the GC computer time equal to the clock time. Record the time in the log book.

15. Install the calibration gas cylinder to the $\mathrm{GC}$ and let the $\mathrm{GC}$ run five times. If at the end of five runs the GC reading is within $10 \%$ of the gas composition in the cylinder, print the calibration check results and write down "pre-cal check and run number" on the printout. Otherwise, select "Calibration" "Level 1" "OK" to calibrate the GC five times. At the end of five runs the GC reading should be within $10 \%$ of the gas composition in the cylinder. If it is not, contact the engineer. Print the calibration check results and write down "pre-cal check and run number" on the printout.

16. Start the GC for this run beginning with baseline reading for a few minutes. Write down the GC time, filename etc. in the logbook. Record the baseline data on the data sheet.

\footnotetext{
${ }^{18}$ Performed in SRAT Heel Preparation Step described in previous run plan.
} 
Westinghouse Savannah River Company Savannah River Technology Center

Run \# $5 \mathrm{~V}$
APPENDIX A-5: Run 5V

APPENDIX A-5:Run SV

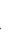

\author{
WSRC-TR-99-00111, Rev. 0 \\ Page 95 of 111
}

Date: 6-17-99

\section{SRAT CYCLE}

1. Add $2.33 \mathrm{~g}$ 1:10 antifoam solution and $2.33 \mathrm{~g}$ water directly to the kettle (100-ppm antifoam).

2. Start heating up the kettle with the TEMP-O-TROL Model TOT-VOVC (yellow box) temperature controller. Turn on its power switch, turn the voltage output dial to maximum (115), press and hold the up $[\Delta]$ and down $[\nabla]$ keys simultaneously until display flashes between TUNE and OFF, then press the up $[\Delta]$ key until display says SPrr, now press and hold the enter $\left[^{*}\right]$ key and the display should show 60 for ${ }^{\circ} \mathrm{C}$ per hour the system will ramp up to reach its setpoint. If the display shows something other than 60 then while pressing the enter $\left[{ }^{*}\right]$ key, press the up or down keys to adjust the value to 60 . To return to the normal temperature display, press and hold up $[\Delta]$ and down $[\nabla]$ keys simultaneously until the temperature is shown. Now press and hold the enter $\left[{ }^{*}\right]$ key to check the current setpoint which should be 93 . If the display shows something other than 93 then while pressing the enter [*] key, press the up or down keys to adjust the value to 93 . Once you release the enter $[*]$ key, a little flashing block [ $\square]$ should appear in the upper left corner of the display and the ON light should illuminate indicating power to the heating mantle. The temperature should ramp to $93^{\circ} \mathrm{C}$ then hold there. Record the run data every 20 minutes on the data sheet.

3. Adjust the setpoint on the TEMP-O-TROL to $110^{\circ} \mathrm{C}$ by pressing and holding the enter $\left[{ }^{*}\right]$ key and pressing the up $[\Delta]$ and down $[\nabla]$ keys. Adjust voltage output to $3.33 \mathrm{~g} / \mathrm{min}$ boil-up rate and bring the kettle contents to boiling.

4. If slurry begins to foam over at any time, switch off heating and turn on the cooling coil water pump to bring the temperature down rapidly. Add antifoam solution as shown in step 1. Then switch off the cooling coil water pump and slowly heat up the kettle again to the point of boiling.

5. Dewater until remove $300 \mathrm{~g}$ of water (kettle volume should be close to De-water Level marked in Step 3 of PREPARATION FOR SRAT CYCLE). Should take about 1 hour and 30 minutes.

6. When dewatering is complete, turn off the heat to kettle, turn on water to cooling coil, and cool the kettle to sub-boiling $\left(90^{\circ} \mathrm{C}\right)$.

7. Add 333.3 $\mathrm{g}$ of Sludge $\mathrm{A}^{\prime}$ to the kettle using 2-liter transfer bottle or beaker.

8. 1 Add second batch of trim chemicals (from Table XLIX) directly to the kettle.

9. Transfer $50 \mathrm{~g}$ of distilled water to the kettle (use to rinse all containers used for adding sludge, poble metals, mercury, etc.). (125.9 $\mathrm{g}$ water used)

10. Allow slurry to cool to $50^{\circ} \mathrm{C}$, monitoring torque every 20 minutes.

11. Pull $10 \mathrm{ml}$ sample for nitrate, nitrite, and formate analysis: Weigh and record in lab book. Add $1 \mathrm{ml}$ of $1 \mathrm{~N} \mathrm{NaOH}$ solution, reweigh, and record in lab book. Label the sample LB SRAT 5V*-0N. 
Westinghouse Savannah River Company

Savannah River Technology Center

Run \#

$5 \mathrm{~V}$
APPENDIX A-5: Run 5V

WSRC-TR-99-00111, Rev. 0

Page 96 of 111

Date: 6-17-99

SRAT CYCLE (continued)

12. Start heating up the kettle with the TEMP-O-TROL Model TOT-VOVC (yellow box) temperature controller. Turn on its power switch, turn the voltage output dial to maximum (115), press and hold the up $[\Delta]$ and down $[\nabla]$ keys simultaneously until display flashes between TUNE and OFF, then press the up $[\Delta]$ key until display says SPrr, now press and hold the enter $\left[{ }^{*}\right]$ key and the display should show 60 for ${ }^{\circ} \mathrm{C}$ per hour the system will ramp up to reach its setpoint. If the display shows something other than 60 then while pressing the enter $[*]$ key, press the up or down keys to adjust the value to 60 . To return to the normal temperature display, press and hold up $[\Delta]$ and down $[\nabla]$ keys simultaneously until the temperature is shown. Now press and hold the enter [*] key to check the current setpoint which should be 93 . If the display shows something other than 93 then while pressing the enter [*] key, press the up or down keys to adjust the value to 93 . Once you release the enter $\left[{ }^{*}\right]$ key, a little flashing block [ $\square$ ] should appear in the upper left corner of the display and the ON light should illuminate indicating power to the heating mantle. The temperature should ramp to $93^{\circ} \mathrm{C}$ then hold there. Record the run data every 20 minutes on the data sheet.

13. Once at $93^{\circ} \mathrm{C}$, add $51.18 \mathrm{ml}$ of $50-w t \%$ nitric acid at $0.663 \mathrm{ml} / \mathrm{min}$ (reference Table $\mathrm{LI}$ ) to the kettle. Should take about 1 hour and 15 minutes.

14. Add $117.87 \mathrm{ml}$ of $\mathbf{9 0}$-wt $\%$ formic acid at $0.687 \mathrm{mi} / \mathrm{min}$ (reference Table LI) to the kettle. Should take about 3 hours.

15. Add $2.33 \mathrm{~g}$ 1:10 antifoam solution and $2.33 \mathrm{~g}$ water directly to the kettle (100 ppm antifoam). 16. $Y$ Adjust the setpoint on the TEMP-O-TROL to $110^{\circ} \mathrm{C}$ by pressing and holding the enter $\left[{ }^{*}\right]$ key and pressing the up $\lceil\Delta\rceil$ and down $\lceil\nabla\rceil$ keys. Adjust voltage output to $3.33 \mathrm{~g} / \mathrm{min}$ boil-un rate and bring the kettle contents to boiling.

17. Dewater until collect $947 \mathrm{~g}$ of $\mathrm{H} 2 \mathrm{O}$ in the SMECT leaving approximately $1.7 \mathrm{~L}$ in the kettle. Should take about 4.7 hours. (Collected $1023 \mathrm{~g}$ due to additional water added earlier)

18. Pull $10 \mathrm{ml}$ sample for nitrate, nitrite, and formate analysis. Weigh and record in lab book. Add $1 \mathrm{ml}$ of $1 \mathrm{~N} \mathrm{NaOH}$ solution, reweigh, and record in lab book. Label LB SRAT 5V*-1N.

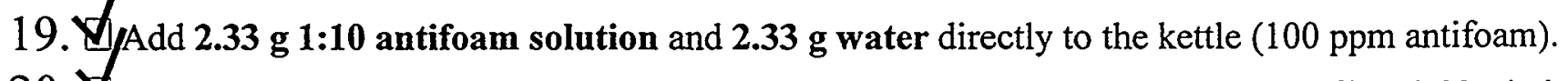

20. Reflux the slurry for 14.2 hours or more (including the dewater time in step 18) at $3.33 \mathrm{~g} / \mathrm{min}$ boil-up taking $10 \mathrm{ml}$ sample for nitrate, nitrite, and formate analysis every 2 hours and one at the end. Continue refluxing until there is evidence of nitrite destruction (hydrogen release) and the hydrogen has reached its peak. Then turn off the heat to cool the kettle to sub-boiling. Weigh samples and record in lab book. Add $1 \mathrm{ml}$ of $1 \mathrm{~N} \mathrm{NaOH}$ solution to each pample, reweigh, and record in lab book. Label as LB SRAT 5V*-2N, 4N, 6N, 8N, 10N, etc.

21. Pull a $125 \mathrm{ml}$ sample from the kettle, record the weight on the run sheet. Label as LB SRAT $5 \mathrm{~V}^{*}$ and send to lab for analyses.

22. Pull a $125 \mathrm{ml}$ sample from the kettle, record the weight on the run sheet. Label as LB SRAT $\mathrm{SV}^{*}$ Rheology and send to lab for Rheology.

23. Remove Sampler and insert rubber stopper in port. 
Westinghouse Savannah River Company Savannah River Technology Center

Run \# $5 \mathrm{~V}$
APPENDIX A-5: Run 5V

WSRC-TR-99-00111, Rev. 0

Page 97 of 111

Date:

$6-21-99$

\section{SME CYCLE}

1. 4 Set the air flow to kettle at $163.8 \mathrm{sccm}$. Set the He flow to $0.82 \mathrm{sccm}$.

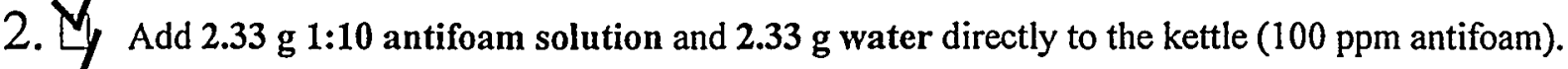

3. Add about $534.23 \mathrm{~g}$ frit 200 to the kettle ( ${ }^{\text {st }}$ frit addition - Table L). Actual amount of frit to add: $\underline{518.67} \mathrm{~g}^{19}$

4. Add about $10.88 \mathrm{~g}$ of $90-\mathrm{wt} \%$ formic acid to the kettle ( $\mathrm{I}^{\text {st }}$ formic addition - Table L). Actual amount of formic to add: $10.57 \mathrm{~g}^{12}$

5. Add about $981.25 \mathrm{~g}$ of water to the kettle ( $1^{\text {st }}$ water addition - Table L). Actual amount of water to add: $952.69 \mathrm{~g}^{12}$

6. Bring kettle contents to boiling. Record the run data every 20 minutes on the data sheet.

7. Remove about $674 \mathrm{~g}$ of water (about 3.4 hours). Actual amount of water to remove: $651 \quad \mathrm{~g}^{12}$

8. When dewatering is complete, turn off the heat to cool the kettle to sub-boiling.

9. Add about $534.23 \mathrm{~g}$ frit 200 to the kettle ( $2^{\text {nd }}$ frit addition - Table L). Actual amount of frit to add: $518.67 \mathrm{~g}^{! 2}$

10. Add about $10.88 \mathrm{~g}$ of 90 -wt $\%$ formic acid to the kettle $\left(2^{\text {nd }}\right.$ formic addition - Table L).Actual pmount of formic to add: $10.57 \mathrm{~g}^{12}$

11. Add about $981.25 \mathrm{~g}$ of water to the kettle ( $2^{\text {nd }}$ water addition - Table L). Actual amount of water to pdd: $952.69 \mathrm{~g}^{12}$

12. Bring kettle contents to boiling. Record the run data every 20 minutes on the data sheet.

13. $V$ Remove about $674 \mathrm{~g}$ of water (about 3.4 hours). Actual amount of water to remove: $651 \quad \mathrm{~g}^{12}$

14. When dewatering is complete, turn off the heat to cool the kettle to sub-boiling. Turn on cooling water

15. 4 to cooling coil dip-leg.

send to lab for analyses.

16. Stop GC and record the GC time and clock time in the logbook. Stop recording run data on the data 17. Install theet.

print a copy and write "post-cal check and run number" on the printout, then place the GC in standby.

If the check is not within $10 \%$ of the cal gas composition, notify the engineer.

18. Hump kettle contents into a tared bottle. Record the weight on the run sheet.

19. Complete $\mathrm{pH}$ meter post calibration check. Record measured $\mathrm{pH}$ in $\mathrm{pH} 7$ buffer 27.37 .

20. Install the outlet flow meter to the purge gas.

21. When the kettle is cool $\left(<50^{\circ} \mathrm{C}\right)$, record the outlet purge flow in the log book. (All channels).

22. $\checkmark$ Turn off all instruments.

${ }^{19}$ Actual amounts calculated after account for SRAT samples pulled and other losses. 


\section{APPENDIX B: CONDUCT OF R\&D REVIEW}

\section{Review of Conduct of R\&D for Large CPC Batch Task}

The Conduct of R\&D from SRTC ${ }^{20}$ as it pertains to the scoping and variability experiments for the DWPF Large CPC Batch study has been reviewed. Please see the attached figures from the Conduct of R\&D document, which have been marked appropriately for the Large CPC Batch work.

Following the logic laid out in the Conduct of R\&D, no new Job or Process Hazards Review is needed for the Large Batch study as similar equipment, procedures, and chemicals that have been used in past experiments will be used in these new experiments. Should the task change then the Conduct of R\&D can be reviewed again to assure all proper protocols are being followed.

\footnotetext{
${ }^{20}$ Conduct of Research and Development, Savannah River Technology Center, March 31, 1998, WSRC-IM-97-00024.
} 
Westinghouse Savannah River Company Savảnnah River Technology Center
APPENDIX B: Conduct of R\&D

WSRC-TR-99-0111, Rev. 0

Page 99 of 111

Figure 1

Conduct of R\&D Summary Flow Diagram

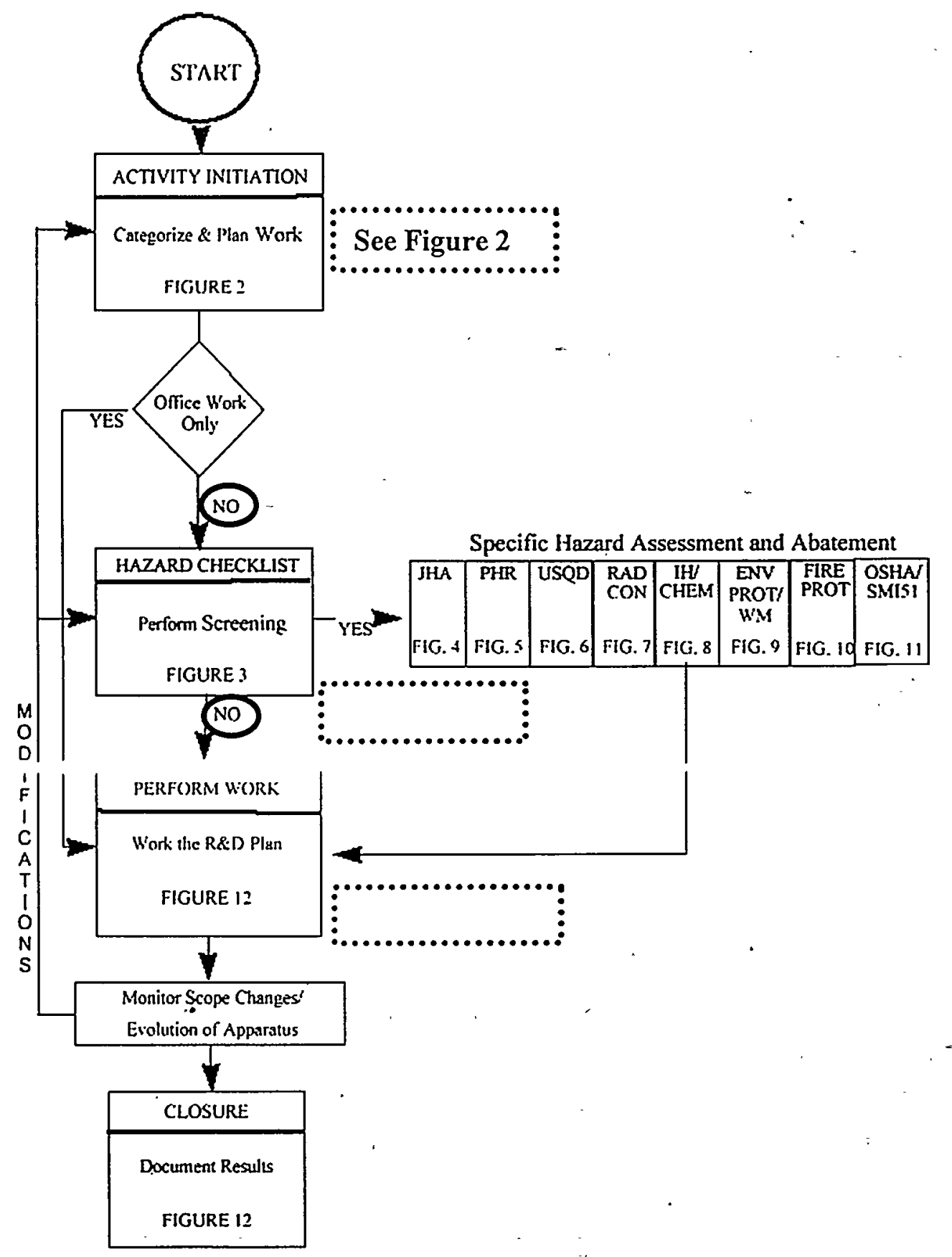




\section{Figure 2}

\section{Work Initiation Process Flow Diagram}

\section{Process Flowchart}

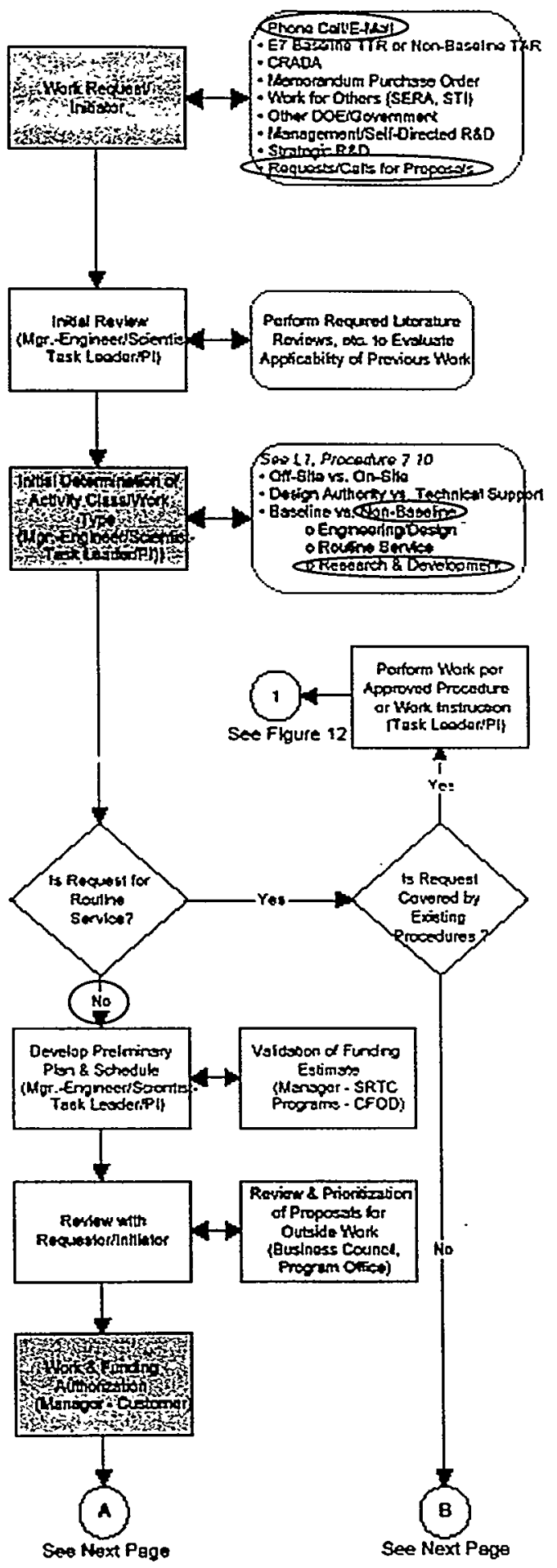

Work initiated through requests, phone calls, and e-mails with customer.
Examined reports on previous work, various literature sources, and spoke with other researchers.

This work is Non-baseline and is for R\&D.
A preliminary plan and schedule was developed so funding and other administration requirements

Meetings were held with the customer so a TTR could be written to meet everyone's needs.

The customer (DWPF) signed off on the TTR and so did we (TTS). 
Figure 2 (contd)

\section{Work Initiation Process Flow Diagram}

\section{Process Flowchart}

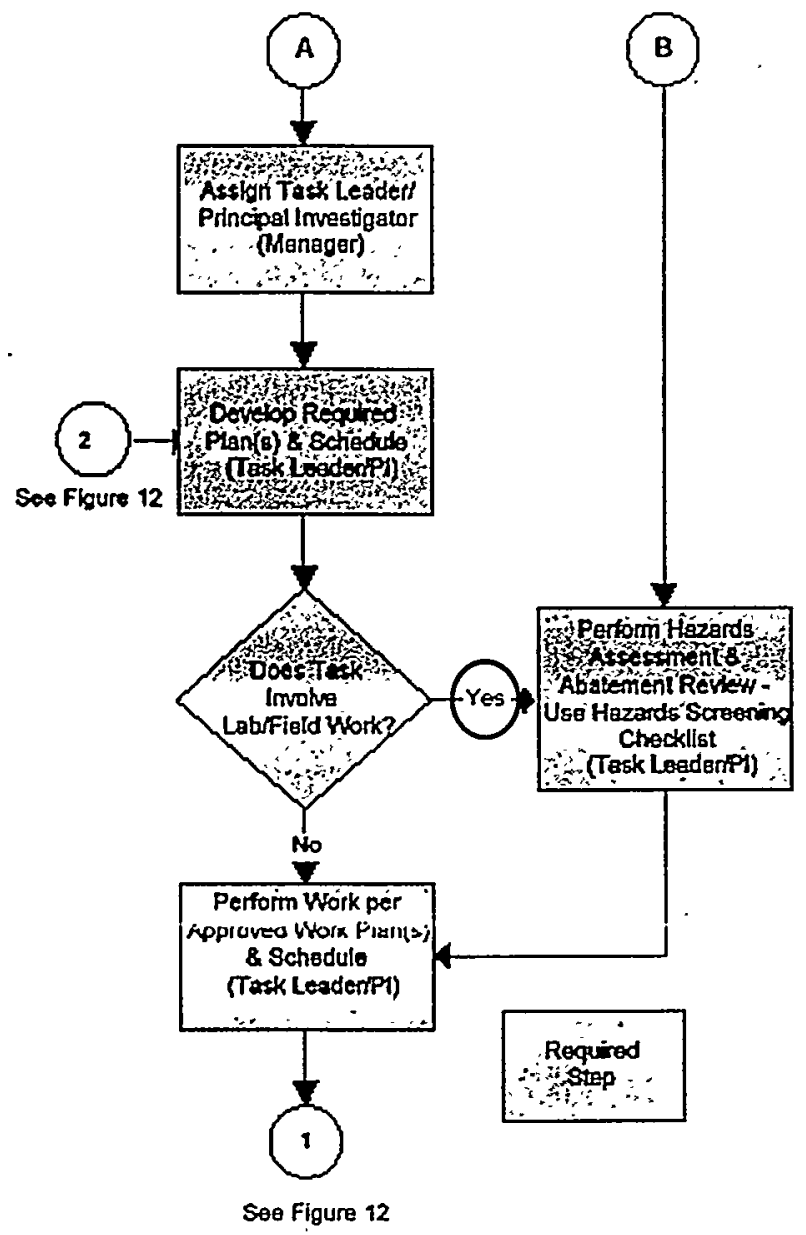

A task leader and principal investigator was assigned to the DWPF large batch work.

A technical task plan was drafted, reviewed, and signed by the customer and other participants.

See Figure 3 for R\&D Hazards checklist. 
Figure 3

\section{R\&D Hazards Screening Checklist}

Listed below are characteristics of an experiment/project that may present hazards above normal risks to SRTC. Circle YES or NO for each item listed. For each "yes" answer you will be directed to a secondary hazard review or reviews that will direct completion of specific actions need to manage/mitigate the identified hazard.

\section{ENERGIES}

A. Electricity (exposed energized parts $>50 \mathrm{~V}$ ).

YES

See Figures $4 \& 11$.

B. Fissionable materials.
YES
ND

Specify:

See Figures 4, 5, 6, 7, 9, \& 11 .

C. High noise levels ( $>85 \mathrm{dBA})$.

YES

(NO)

See Figures $4,8, \& 11$.

D. Microwave/radiofrequencies (30 KHz- $300 \mathrm{GHz})$, electric or magnetic fields.

\section{YES NO}

See Figures 4, 8, \& 11.

E. Lasers (other than class 1).

See Figures $4,8, \& 11$.

F. Moving equipment (exposed belts, chins, gears, pinch rollers, pulleys, rotating shafts/blades, wheels

See Figures $4 \& 11$.

G. Radioactive materials

YES

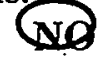

Specify: Radionuclides:

Amount:

Physical Form:

See Figures 4, 5, 6, 7, 9, \& 11 .

H. Static magnetic fields $>600$ Gauss.

See Figures 4, 8, \& 11. 
Figure 3

R\&D Hazards Screening Checklist

I. Sub-radiofrequency ( $<30 \mathrm{KHz}$ ) electric and magnetic fields.

See Figures 4, 8, \& 11.

J. Temperatures $\left(<32^{\circ} \mathrm{F}\right.$ or $\left.>150^{\circ} \mathrm{F}\right)$. Consider furnaces, ovens, dryers, boilers, steam systems, heaters, dewars, chillers, and release of compressed gases.

QES NO

See Figures 4, 8, 10, \& 11 .

K. Vacuum (external pressure $>15 \mathrm{PSI})$.

YES

See Figures 4, 8, \& 11 .

L. Pressure (compressible materials $>30 \mathrm{PSI}$; or noncompressible materials $>150 \mathrm{PSI}$ ). YES WD

See Figures 4, 8, \& 11 .

M. Pressure vessels ( $>$ 15PSI and $>6$ "ID; and/or contain toxic, corrosive, or nuclear materials). YES

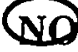

See Figures $4,8 \& 11$.

WORKSITE ENVIRONMENTAL CONDITIONS

A. Boating or work over water.

$$
\text { YES ND }
$$

See Figure 4, 8, \& 11 .

B. Cold or heat stress conditions.

$$
\text { YES NO }
$$

See Figure 4, 8, \& 11 .

C. Confined spaces/trenches/or evacuations.

YES

ad

See Figures 4, 8, \& 11.

D. Flammable atmospheres $(>10 \%$ LEL).

YES

ad

See Figures 4, 8, 10, \& 11 .

E. Oxygen deficient atmosnheres $\left(<19.5 \% \mathrm{O}_{2}\right)$.

$$
\text { YES WO }
$$

See Figures 4, 8, \& 11. 
Figure 3 (continued)

R\&D Hazards Screening Checklist

F. Toxic atmosphere (airborne contaminant concentrations expected to exceed $50 \%$ of the Threshold Limit Value) YES VD

See Figures 4, 5, 8, \& 11 .

G. Activity performed in a nuclear facility. YES

NO

See Figure 6.

H. Work with radioactive or contaminated material or entry into contolled area. YES Qd

See Figures $6 \& 7$

\section{HAZARDOUS MATERIALS}

A. Biological Agents. YES

See Figures 4, 5, 8, 9, \& 11 .

B. Carcinogens, mutagens, teratogens.

$$
\text { YES ND }
$$

Specify:

See Figures 4, 5, 8, 9, \& 11 .

C. Corrosives.

$$
\text { Yes } \mathrm{NO}
$$

See Figures 4, 5, 8, 9, \& 11.

D. Cryogenic gases/liquids.

$$
\text { YES }
$$

See Figures 4, 8, \& 11.

E. Flammable/combustible gases, liquids, solids.

$$
\text { YES }
$$

Specify:

\section{ND}

See Figures 4, 5, 8, 9, 10, \& 11 .

F. Toxic Chemicals.

\section{बES NO}

Specify: Mercury, Cadmium

See Figures 4, 5, 8, 9, \& 11 .
Amount:

Amount: $\quad 40$ grams, 10 grams 
Westinghouse Savannah River Company Savannah River Technology Center .

Figure 3 (continued)

R\&D Hazards Screening Checklist
APPENDIX B: Conduct of R\&D

WSRC-TR-99-0111, Rev. 0

Page 105 of 111

G.

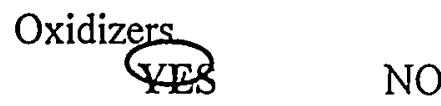

Specify: Nitric Acid Amount: $220 \mathrm{ml}$

See Figures 4, 5, 8, 9, 10, \& 11 .

H. Hydrocarbons (>55 gallons).

$$
\text { YES WO }
$$

See Figures 4, 5, 8, 9, \& 11 .

I. Any hazardous substance.

$$
\text { Yes NO }
$$

Specify: Formic Acid

See Figures 4, 5, 8, 9, \& 11 .

\section{ENVIRONMENTAL COMPLIANCE}

A. Release of regulated gas or particulate to the environment.

$$
\text { ves NO }
$$

See Figure 9.

Experiments fall within permitted limits of hoods.

B. Release of regulated materials to a waste disposal system. YES

See Figure 9.

C. Waste disposal problems (including equipment).

See Figure 9.

D. Creation of radioactive yzaste.

$$
\text { YES QIO }
$$

See Figure 9. 
Westinghouse Savannah River Company

Savannah River Technology Center
APPENDIX B: Conduct of R\&D

WSRC-TR-99-0111, Rev. 0

Page 106 of 111

\section{Figure 4}

\section{Job Hazards Analysis (JHA) Flowchart}

\section{Process Flowchart}

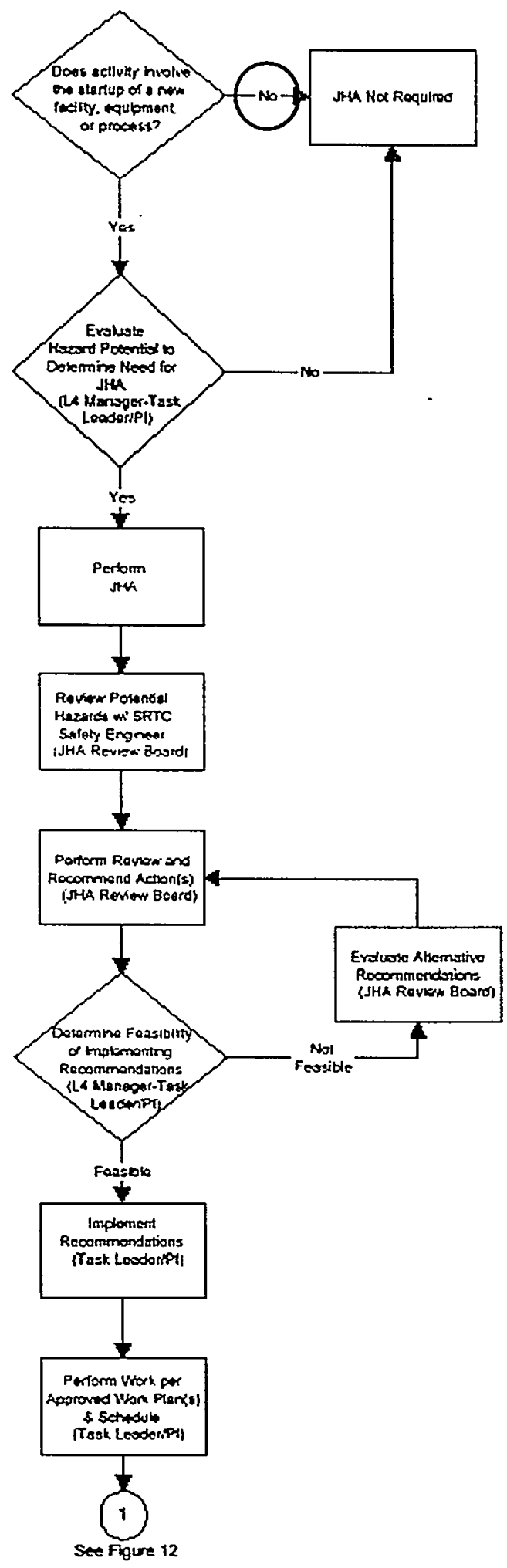


Westinghouse Savannah River Company Savannah River Technology Center
APPENDIX B: Conduct of R\&D

WSRC-TR-99-0111, Rev. 0

Page 107 of 111

\section{Figure 5}

\section{Process Hazards Review (PHR) Flowchart}

Process Flowchart

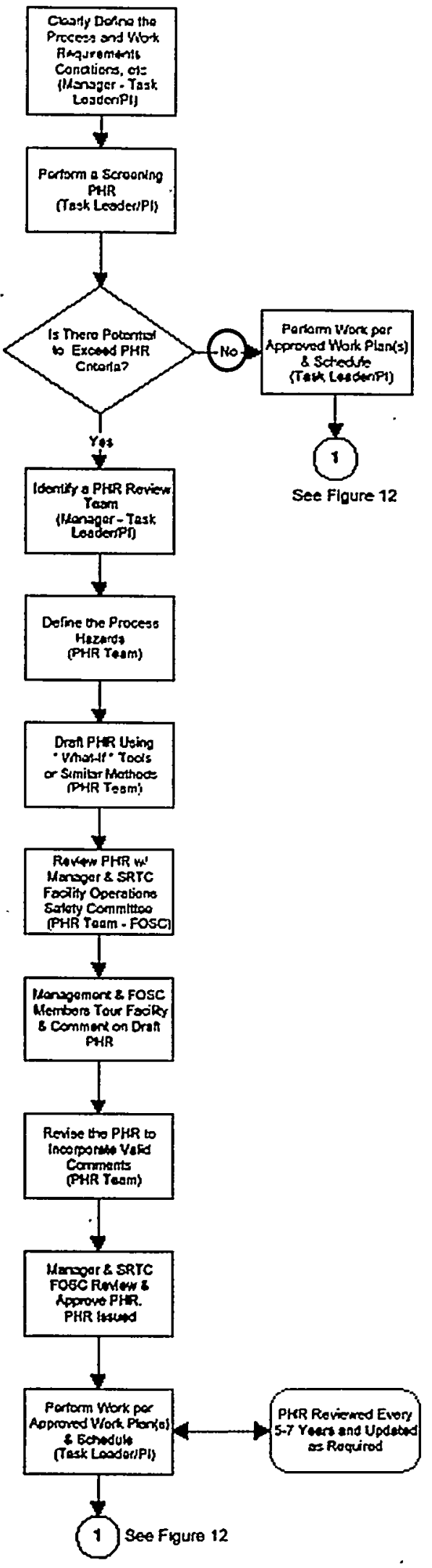

Technicians will be working with 50 weight percent nitric acid and 90 weight percent formic acid solutions.

Technicians have worked with these and other hazardous materials and are not exposed at any greater risk than in past experiments. 
Figure 8

Industrial Hygiene \& Chemical Control Flowchart

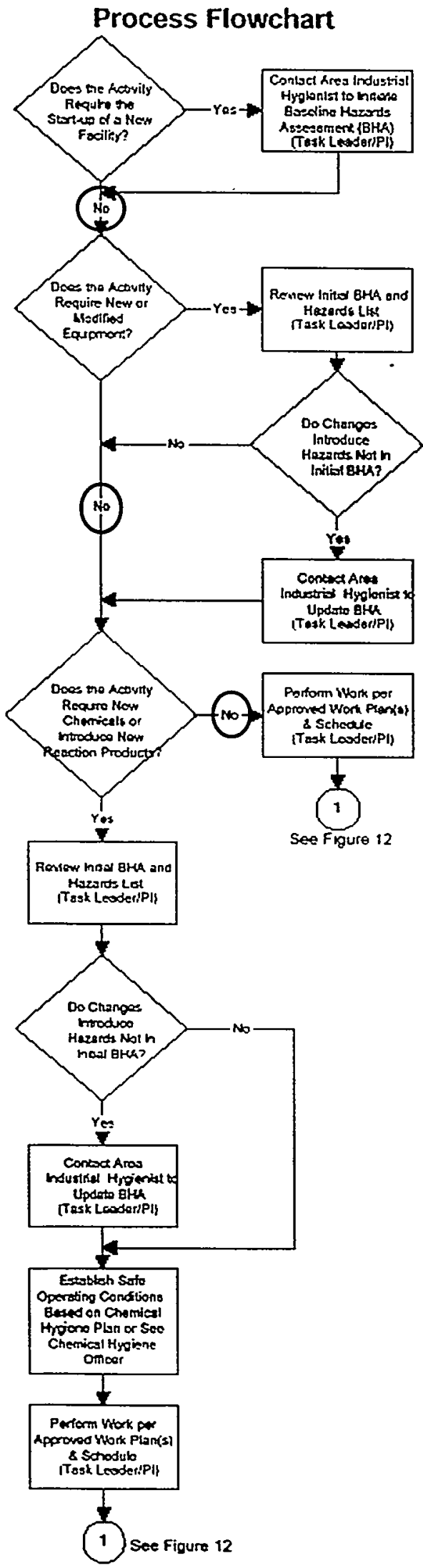


Westinghouse Savannah River Company Savannah River Technology Center
APPENDIX B: Conduct of R\&D

WSRC-TR-99-0111, Rev. 0

Page 109 of 111

\section{Figure 9}

\section{Environmental Protection \& Waste Management Flowchart}

\section{Process Flowchart}

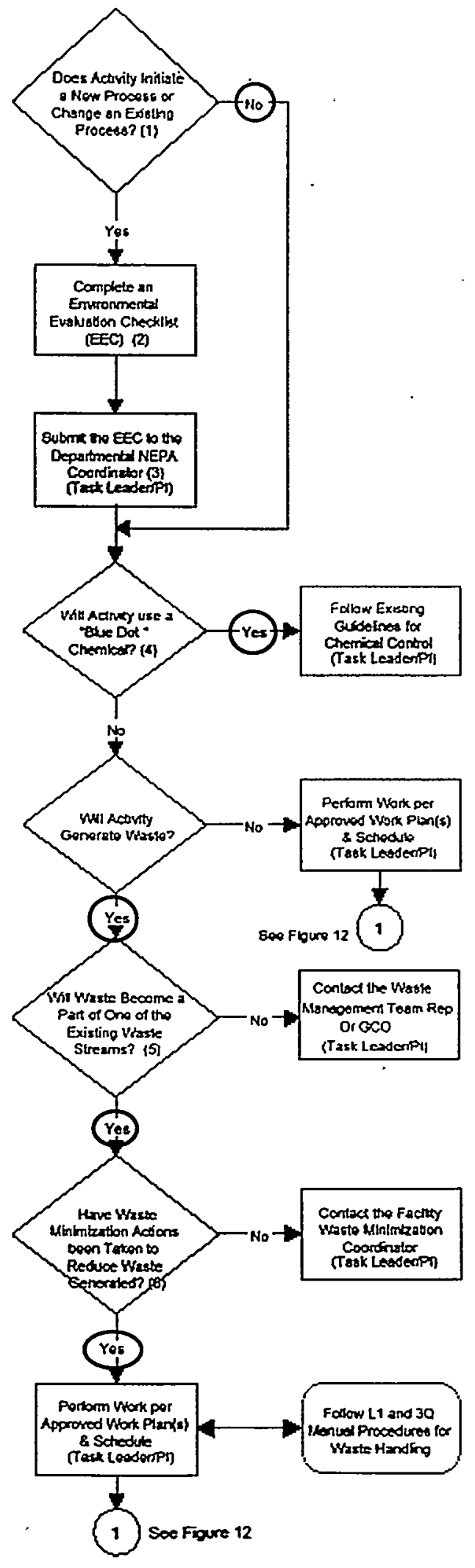

The technicians have dealt with these type of materials in the past and are trained on how to handle it. 
Westinghouse Savannah River Company

Savannah River Technology Center

Figure 10

Fire Protection Flowchart

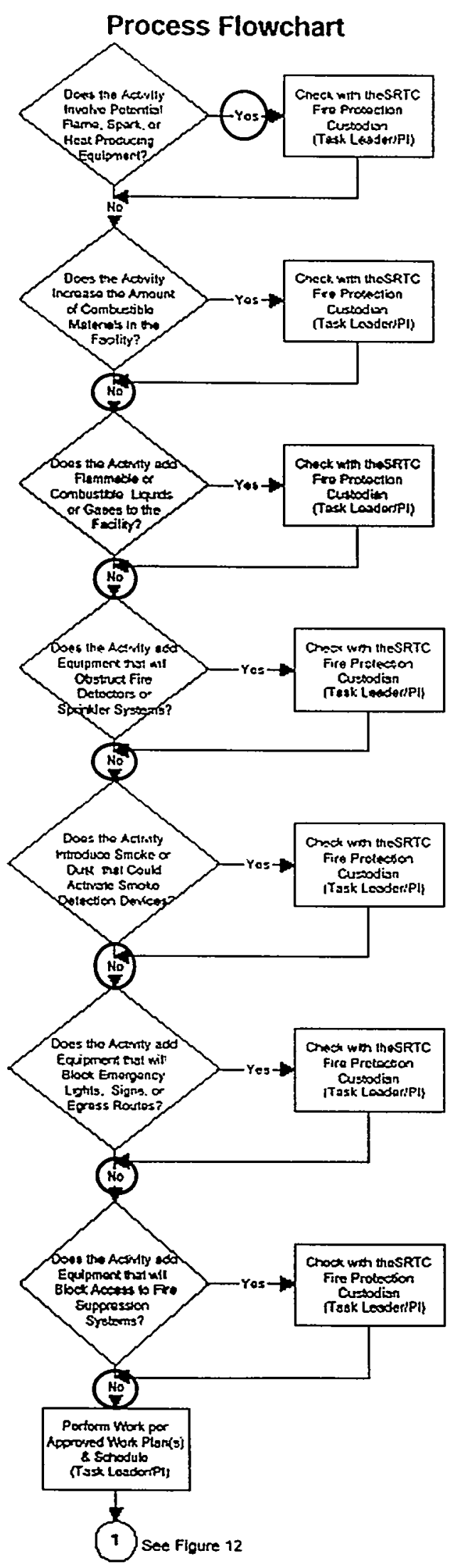

APPENDIX B: Conduct of R\&D

WSRC-TR-99-0111, Rev. 0

Page 110 of 111
The experimental equipment includes a heating mantle that has been used in many previous experiments and meets all safety guidelines. 
Figure 11

Safety Inspection (SMI-51) Flowchart

\section{Process Flowchart}

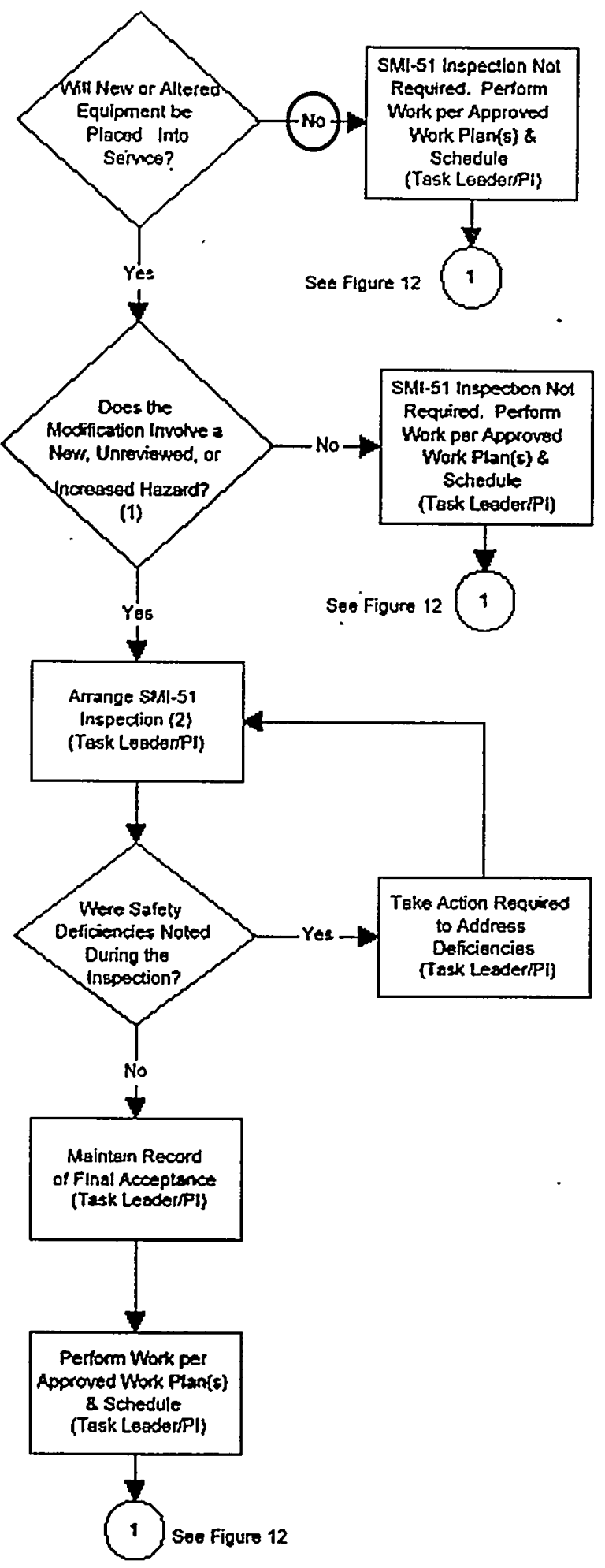




\section{DISTRIBUTION:}

L. M. Papouchado, 773-A

E. W. Holtzscheiter, 773-A

J. T. Carter, 704-3N

H. H. Elder, 704-3N

T. J. Lex, 703-H

J. P. Morin, 703-H

M. N. Brosee, 704-S

J. F. Ortaldo, 704-S

R. E. Edwards, Jr. 704-25S

M. R. Norton, 704-27S

J. E. Occhipinti, 704-27S

W. D. Kerley, 704-S

P. H. Werling, 704-27S

P. M. Patel, 704-27S

L. F. Landon, 704-1T

S. L. Marra, 704-T

R. E. Eibling, 704-T

P. R. Monson, 704-1T

D. P. Lambert, 704-1T

W. E. Daniel, 704-1T

M. F. Williams, 704-1T

STI, 703-43A (4) 